\author{
UNIVERSIDADE DE SÃO PAULO \\ INSTITUTO DE PSICOLOGIA \\ Programa de Pós-Graduação em Psicologia Social
}

MARCOS BADER

Gestão do Relacionamento com Clientes na Indústria Financeira de Varejo: Uma Abordagem da Psicologia Social

São Paulo 
MARCOS BADER

\section{Gestão do Relacionamento com Clientes na Indústria Financeira de Varejo: Uma Abordagem da Psicologia Social}

Tese apresentada ao Instituto de Psicologia da Universidade de São Paulo para a obtenção do título de Doutor em Psicologia.

Área de Concentração: Psicologia Social Orientadora: Professora Doutora Anna Mathilde Pacheco e Chaves Nagelschmidt v.1

São Paulo 
AUTORIZO A REPRODUÇÃO E DIVULGAÇÃO TOTAL OU PARCIAL DESTE TRABALHO, POR QUALQUER MEIO CONVENCIONAL OU ELETRÔNICO, PARA FINS DE ESTUDO E PESQUISA, DESDE QUE CITADA A FONTE.

Catalogação na publicação

Serviço de Biblioteca e Documentação

Instituto de Psicologia da Universidade de São Paulo

Bader, Marcos

Gestão do relacionamento com clientes na Indústria financeira de varejo: uma abordagem da psicologia social/ Marcos Bader; orientadora: Anna Mathilde Pacheco e Chaves Nagelschmidt. -- São Paulo, 2007.

$2 \mathrm{v}$.

Tese (Doutorado - Programa de Pós Graduação em Psicologia. Área de concentração: Psicologia Social e do Trabalho) - Instituto de Psicologia da Universidade de São Paulo.

1. Tipos psicológicos. 2. Psicologia do consumidor. 3 Comportamento do consumidor. 4 Comportamento econômico. 5 Desempenho no trabalho. 6 Bancos. I Título.

HF5415.32 


\section{FOLHA DE APROVAÇÃO}

Marcos Bader

Gestão do Relacionamento com Clientes na Indústria Financeira de Varejo: Uma Abordagem da Psicologia Social.

Tese apresentada ao Instituto de Psicologia da Universidade de São Paulo para obtenção do título de Doutor.

Área de Concentração: Psicologia Social.

Aprovado em:

Banca Examinadora

Prof.Dr.

Instituição:

Assinatura:

Prof.Dr

Instituição:

Assinatura:

Prof.Dr.

Instituição:

Assinatura:

Prof.Dr.

Instituição:

Assinatura:

Prof.Dr.

Instituição: Assinatura: 
DEDICATÓRIA

À minha Família 


\section{AGRADECIMENTOS}

Muitas pessoas colaboraram para a realização deste trabalho, dedicando-me seu tempo e atenção, a todas sou profundamente grato.

É com imenso prazer que registro a oportunidade de ter contado com a amizade e incentivo daqueles que considero especiais, a quem desejo particularmente agradecer:

À Professora Doutora Anna Mathilde Pacheco e Chaves Nagelschmidt, na qualidade de orientadora e incentivadora, pelo valioso apoio, transmissão de confiança, extrema solicitude, motivação, conhecimento e erudição que se mostraram verdadeiramente imprescindíveis para a realização deste trabalho;

Ao Professor Doutor José Roberto Ferreira Savóia, amigo e colaborador constante, pelas importantes sugestões e construtivas críticas;

À Professora Doutora Eda Terezinha de Oliveira Tassara pela argüição precisa e relevante contribuição para a estruturação desta pesquisa;

Aos amigos Patricia Donadio Bernacci e Ricardo Luís Nascimento Silva por sua dedicada colaboração na obtenção de dados e referências bibliográficas, apuração dos indicadores e estatísticas utilizados, organização e consolidação de conceitos e proveitosa troca de idéias;

À Escola BCN - Banco de Crédito Nacional e aos seus Professores, onde tive o privilégio de estudar;

À Escola Bradesco e aos seus Professores, onde tenho o privilégio de estudar;

Aos meus sogros e cunhado, Clara, Maurício e Sérgio Cymrot pelo apoio e amizade;

Ao meu irmão, cunhada e sobrinhos, Rubens, Rayana, Josef, Kenneth e Jimmy Bader pelo verdadeiro exemplo de união e companheirismo;

Aos meus pais, Chana e Moniek Bader, minha maior lição e exemplo de vida, por seus ensinamentos e por minha formação;

À minha esposa, Fani Léa Cymrot Bader e aos meus filhos Stephanie e Michel Bader, pelo afeto, amor e estímulo que me dedicaram, tornando possível a concretização desta importante etapa. 


\section{RESUMO}

BADER, Marcos. Gestão do Relacionamento com Clientes na Indústria Financeira de Varejo: Uma Abordagem da Psicologia Social. 2007. 2v.. Tese: (Doutorado) - Programa de Pós Graduação em Psicologia Social, Instituto de Psicologia da Universidade de São Paulo, São Paulo, 2007.

A economia mundial encontra-se em estado de constante mudança impulsionada por fatores como desintermediação e desregulamentação que aliadas à evolução tecnológica resultam na redução de elos das cadeias de valor agregado que unem agentes que ofertam e demandam produto e serviços. O resultado dessa redução de elos é uma crescente aproximação entre os extremos das cadeias de valor agregado. Os canais de distribuição cumprem o importante papel de promover a entrega de produtos e serviços do agente que oferta para o agente demandante. $\mathrm{Na}$ indústria financeira de varejo os canais eletrônicos de distribuição já respondem por aproximadamente $85 \%$ das transações, reconfigurando portanto a logística de distribuição bancária que têm como forçasmotrizes a convergência e a mobilidade. Nos canais eletrônicos bancários o cliente se identifica antes de realizar sua transação, transformando dessa maneira o fluxo pré-identificado de clientes no ativo mais valioso da instituição, fazendo do uso eficaz de sua ferramenta de gestão do relacionamento com cliente, um instrumento de vantagem competitiva. No sentido de se conferir uma maior capacidade de interpretação à ferramenta de gestão do relacionamento com clientes, buscou-se incorporar os tipos psicológicos ao elenco de variáveis que descrevem seu comportamento financeiro. O presente estudo utilizou uma amostra de 876 atendentes de um call center de uma instituição financeira de varejo com o propósito de se identificar evidências de associação entre os tipos psicológicos dos atendentes, apurados pela aplicação do Keirsey Temperament Sorter, e seus comportamentos financeiros e desempenhos profissionais. Foram desenvolvidas análises descritivas e qualitativas. As atitudes Introversão Extroversão apresentaram-se como as variáveis com maior poder de explicação das evidências de associação encontradas.

Palavras Chave: Tipos psicológicos, Psicologia do consumidor, Comportamento do consumidor, Comportamento econômico, Desempenho no Trabalho, Bancos. 


\begin{abstract}
BADER, Marcos. Customer Relationship Management in the Retail Financial Industry: A Social Psychological Approach. 2007. 2v. Thesis: (Doctoral) Programa de Pós Graduação em Psicologia Social, Instituto de Psicologia da Universidade de São Paulo, São Paulo, 2007.

World economy is facing an ever changing scenario due to desintermediation, deregulation and technology evolution causing a reduction in the size of the value added chain that gathers demand and offer economic agents. The distribution channels play the important role of delivering products and services from the offer agent to the demand agent. In the retail banking industry the electronic channels, that represent approximately $85 \%$ of the transactions, are reshaping the distribution logistics empowered by two main drivers: convergence and mobility. In the banking electronic channels the customer has to identify himself before he does his transaction, by doing so the pre identified flow of customers becomes the most valuable corporate asset, transforming the CRM into a competitive advantage tool. In order to provide the CRM a better understanding, the psychological types were added to the variables that describe the customer behavior. This study used a sample of 876 attendants from a retail bank call center searching for evidences of association among psychological types of the attendants that answered the Keirsey Temperament Sorter, and their financial behavior and professional performance. Descriptive and qualitative analysis were developed. Introversion and Extraversion attitudes were the variables that showed the more significant evidences among the associations that were found.
\end{abstract}

Key Words: Psychological Types, Consumer Psychology, Consumer Behavior, Behavioral Economics, Job Performance, Banks. 
LISTA DE FIGURAS .....................................................................................

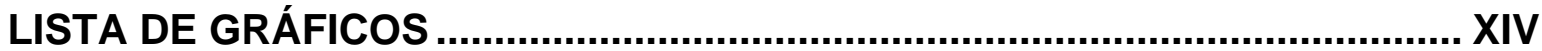

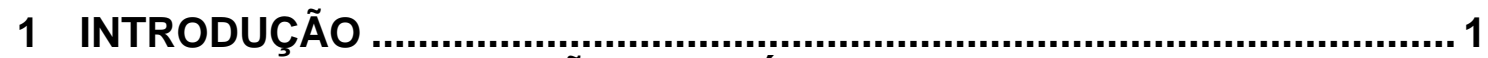

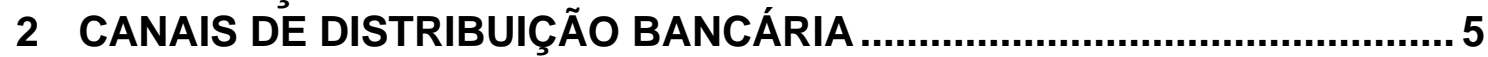

2.1 Exposição do assunto ......................................................... 5

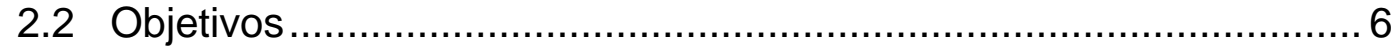

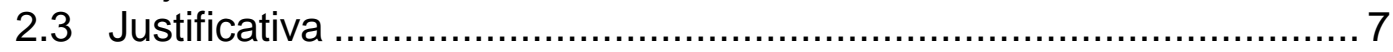

2.4 Evolução de Manufaturas de Grande Volume ................................. 8

2.5 Função Bancária e Financeira ………………................................ 10

2.6 Produtos e Serviços............................................................... 11

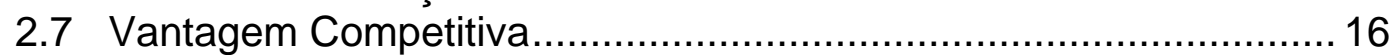

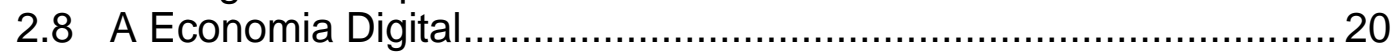

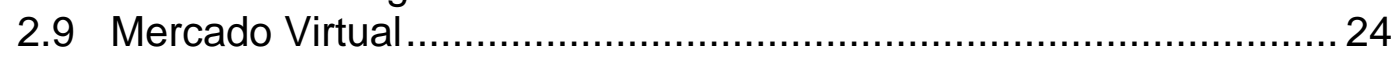

2.10 Banco Virtual - O Banco Móvel sem agências ............................... 28

2.10 .1 Conceito ................................................................. 29

2.10.2 Gestão do relacionamento com o Cliente ………................ 30

2.10.3 Organização do Banco Virtual............................................. 33

2.10.4 Proposta de Segmentação Lógica do Mercado ..................... 35

2.10.5 Valores do Banco Virtual.................................................... 37

2.10.5.1 Valores Mercadológicos ........................................... 37

2.10.5.2 Valores Econômico-Financeiros ................................. 38

2.10.5.3 Valores Tecnológicos ................................................ 39

2.10.6 Oportunidades - Especialização e Benefícios ...................... 40

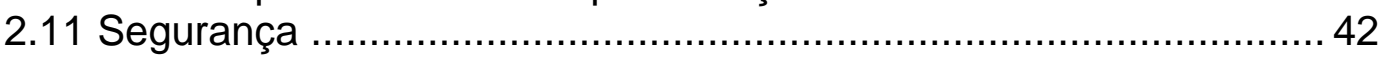

2.12 Marketing de Relacionamento ............................................... 44

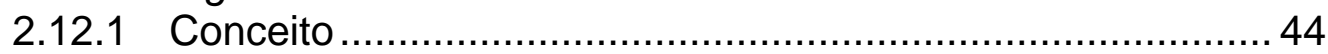

2.12.2 Passado e Futuro .......................................................... 46

2.12.3 Marketing one-to-one ................................................... 47

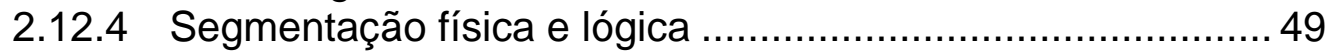

2.12.5 CRM - Conceito ............................................................. 56

2.12.6 CRM - Tecnologia de Relacionamento - Database

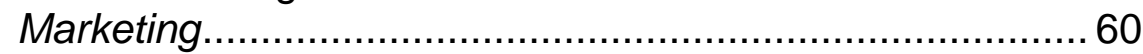

2.12.7 Mudanças de Cenários face às Múltiplas

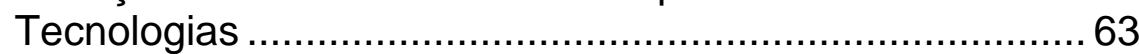

2.12.8 Tecnologias Emergentes no Sistema Financeiro ................... 65 2.13 Conseqüências do Novo Paradigma na Distribuição Bancária

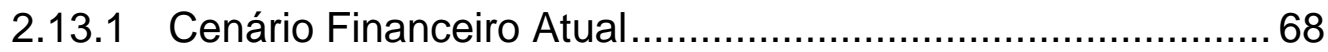

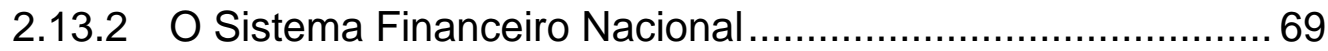

2.13.3 Tendências da Indústria Bancária ……………..................... 70

2.13.3.1 Clientes: .......................................................... 70

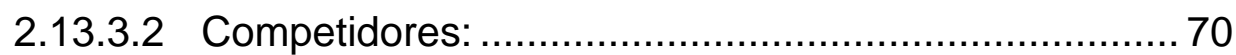

2.13.3.3 Capital Humano:........................................................ 71

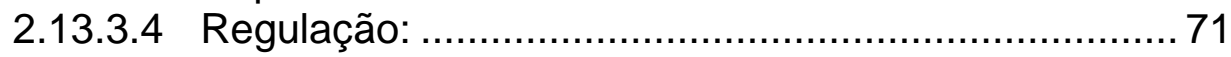

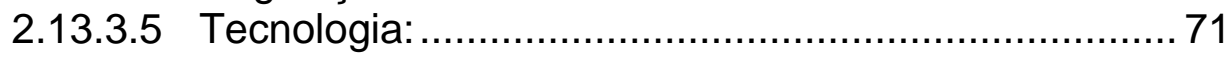


2.13.4 Conseqüência do Novo Paradigma na Distribuição

Bancária ...................................................................... 74

2.13.5 Canais Remotos de Distribuição Bancária ......................... 75

2.13.5.1 Ação Sobre a Visão do Cliente ................................. 77

2.13.5.2 Convergência e Mobilidade ....................................... 79

2.13.5.3 Ciclo do Novo Canal............................................ 84

2.13.5.4 Modelos de Propensão....................................... 87

2.13.5.5 Ciclo de Relacionamento..................................... 88

2.13.5.6 Potencial para ações de Vendas ............................. 91

2.13.5.7 Gestão Integrada............................................... 92

2.13.5.8 Perspectiva Ampliada - Necessidades não

2.14 Conclusões .......................................................................... 102

financeiras - Market Place - Comércio Eletrônico ... 100

2.14.1 Considerações Gerais.................................................. 102

2.14.1.1 Mudança de Estratégia......................................... 102

2.14.1.2 Gestão do Relacionamento com Clientes ............... 103

2.14.1.3 Tecnologia, Gerenciamento e Indivíduo.................. 106

2.14.1.4 Inovação.................................................... 108

2.14.2 Considerações Finais ................................................... 114

2.14.2.1 Interpretando o Novo Paradigma da Distribuição Bancária, frente ao comportamento Humano........... 114

3 TIPOS PSICOLÓGICOS ................................................................ 117

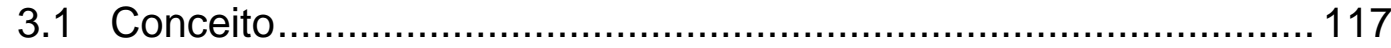

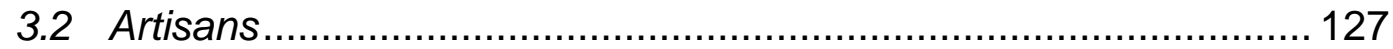

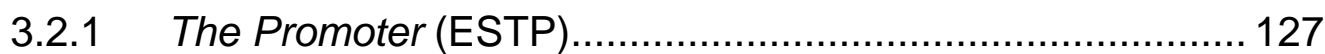

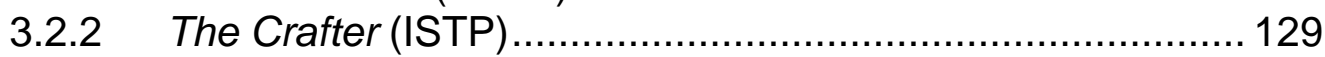

3.2.3 The Performer (ESFP) ...................................... 130

3.2.4 The Composer (ISFP) ........................................... 131

3.2.5 Exemplos de Representantes dos Artisans..................... 132

3.3 Guardians ..................................................................... 132

3.3.1 The Supervisor (ESTJ) ...................................... 133

3.3.2 The Inspector (ISTJ) ............................................. 134

3.3.3 The Provider (ESFJ) .............................................. 135

3.3.4 The Protector (ISFJ) ............................................. 136

3.3.5 Exemplos de Representantes dos Guardians .................. 137

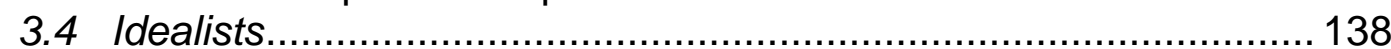

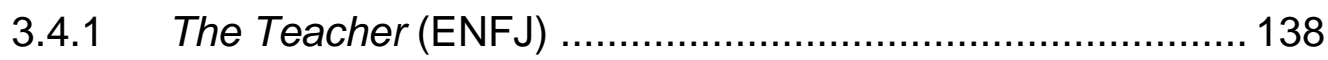

3.4.2 The Counselor (INFJ) ........................................ 139

3.4.3 The Champion (ENFP) ...................................... 141

3.4.4 The Healer (INFP) ................................................ 142

3.4.5 Exemplos de Representantes dos Idealists ..................... 143

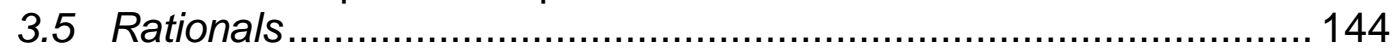

3.5.1 The Fieldmarshal (ENTJ) ........................................ 144

3.5.2 The Mastermind (INTJ) .......................................... 146

3.5.3 The Inventor (ENTP) ........................................... 147

3.5.4 The Architect (INTP) ….......................................... 148

3.5.5 Exemplos de Representantes dos Rationals................... 149

3.6 Considerações Adicionais ................................................. 150

4 QUESTÕES OBJETO DESSE ESTUDO ............................................. 151

5 METODOLOGIA ............................................................................... 156 
5.1 Seleção da Amostra.............................................................. 156

5.1.1 Critérios de seleção da amostra..................................... 156

5.1.2 Representatividade da amostra ................................... 158

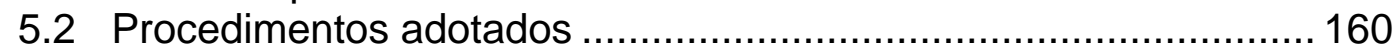

5.3 Método de Análise dos Dados ................................................... 165

5.4 Testes Estatísticos............................................................... 169

5.5 Resultado da Aplicação do Teste Keirsey Temperament

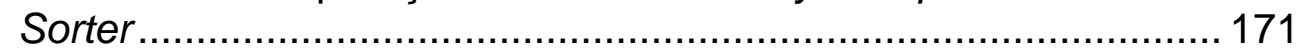



6.1 Demográfico........................................................................... 173

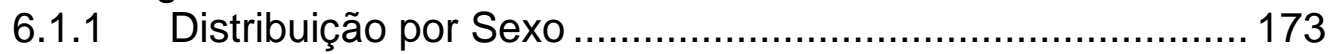

6.1.2 Distribuição por Estado Civil ............................................ 174

6.1.3 Distribuição por Faixa Etária ........................................... 174

6.1.4 Distribuição por Região Geográfica ................................. 175

6.2 Relacionamento com o Banco …............................................. 176

6.2.1 Distribuição por Tempo de Relacionamento ...................... 176

6.2.2 Distribuição por Posse de Cartão de Crédito ...................... 176

6.2.3 Distribuição por Utilização de Produtos Bancários................ 177

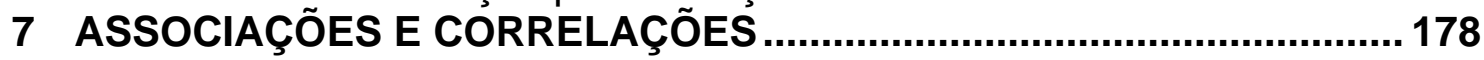

7.1 Relação Temperamentos vs. Perfil da Base ................................ 178

7.1.1 Perfil Psicológico vs. Perfil Demográfico ............................ 179

7.1.1.1 Sexo vs. Perfil Psicológico ……………................ 179

7.1.1.2 Faixa Etária vs. Perfil Psicológico............................. 185

7.1.2 Perfil Psicológico vs. Perfil de Utilização de

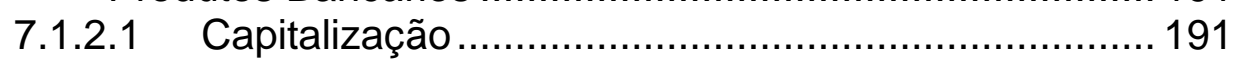

7.1.2.2 Cartão de Crédito .................................................... 198

7.1.2.3 Aplicações em CDB - Certificado de Depósito

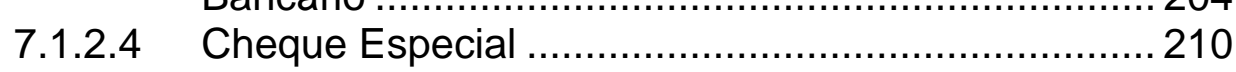

7.1.2.5 Empréstimos e Financiamentos ............................. 216

7.1.2.6 Aplicação em Fundos de Investimentos .................... 222

7.1.2.7 Crédito Pessoal ................................................... 228

7.1.2.8 Previdência............................................................ 234

7.1.2.9 Renegociação de Crédito ....................................... 240

7.1.3 Conclusões Relevantes dos Temperamentos vs.

Perfil da Base ......................................................... 246

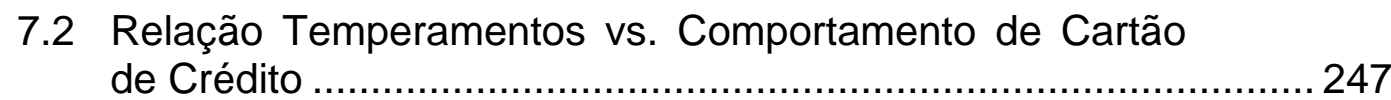

7.2.1 Segmentação dos Usuários de Cartão ................................ 250

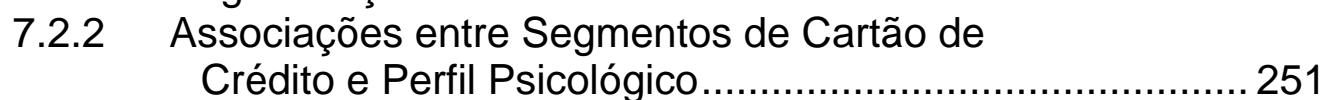

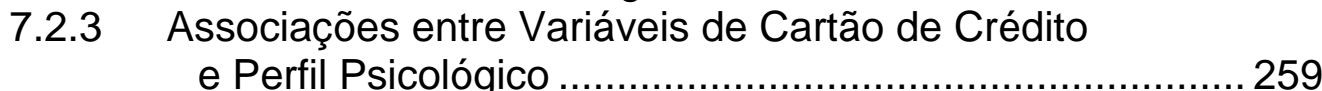

7.2.4 Conclusões Relevantes dos Temperamentos vs.
Comportamento de Cartão de Crédito .............................. 292

7.3 Relação Temperamentos vs. Ótica Econômica (Poupança 
7.3.1 Associações entre Faixas da Graduação das Dimensões dos Temperamentos e as Variáveis de Ótica Econômica 294

7.3.2 Conclusões Relevantes dos Temperamentos vs. Ótica Econômica 308

7.4 Relação Temperamentos vs. Desempenho Profissional ................ 310

7.4.1 Desempenho Comercial vs. Perfil Psicológico ..................... 311

7.4.2 Avaliação do Desempenho vs. Perfil Psicológico.................. 312

7.4.3 Conclusões Relevantes do Perfil Psicológico vs. Desempenho Profissional

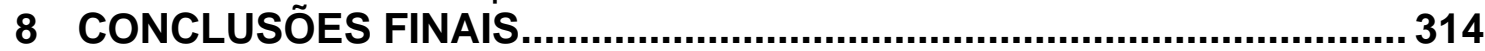

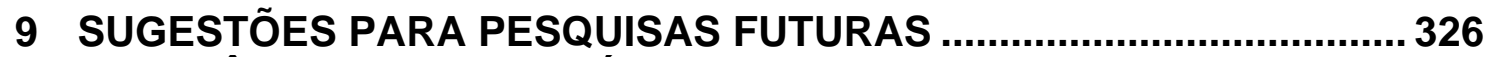



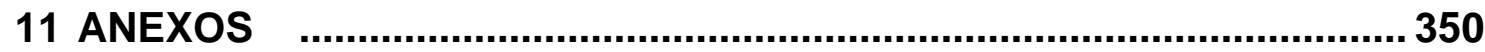

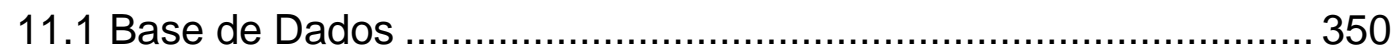

11.1.1 Informações analíticas (Consultar volume 2) ...................... 350

11.2 Testes Estatísticos (Consultar volume 2) .................................... 494 


\section{LISTA DE FIGURAS}

Figura 1 - Evolução de Manufaturas de Grande Volume ................................... 9

Figura 2- Fluxo de Intermediação Financeira ................................................. 11

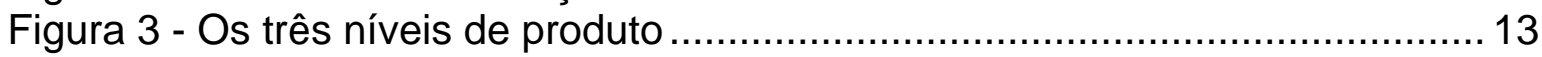

Figura 4 - Quatro características dos serviços ......................................... 15

Figura 5 - Consolidação do Banco Virtual ............................................. 30

Figura 6 - Dinâmica da Gestão de Relacionamento ......................................... 32

Figura 7 - Revendo a segmentação ........................................................... 40

Figura 8 - Marketing de Relacionamento passado e futuro ................................. 46

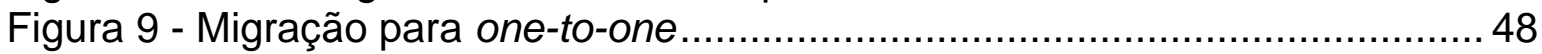

Figura 10- Desempenho nas vendas de músicas Rhapsody ............................. 52

Figura 11- Desempenho nas vendas de músicas Rhapsody ............................. 53

Figura 12 - Segmentação Física e Lógica .................................................. 55

Figura 13 - Principais Processos para viabilizar o CRM ............................... 59

Figura 14 - Tecnologias Emergentes - Processo de Automação Bancária .......... 67

Figura 15 - Da "Bell curve" à "well curve" ......................................................... 72

Figura 16 - Transformação do panorama dos serviços bancários de varejo .........74 74

Figura 17 - Ação sobre a visão do Cliente ..................................................... 77

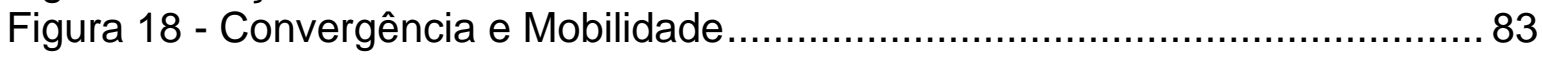

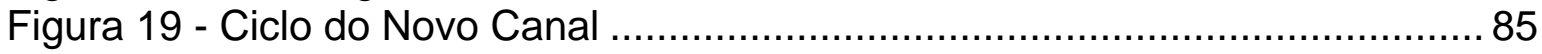

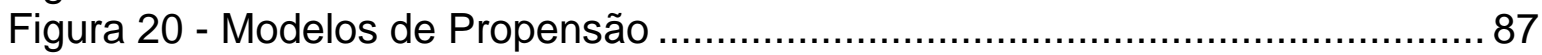

Figura 21- Ciclo de Relacionamento ........................................................ 88

Figura 22 - Interação com o Cliente Call Center ............................................. 89

Figura 23 - Potencial para Ações de Vendas ................................................ 91

Figura 24- Aplicação do CRM para a Otimização do Relacionamento Cliente x Banco. ............................................................................ 92

Figura 25 - Gestão Integrada ........................................................ 93

Figura 26 - Relacionamento dos Clientes - Canais Físicos ............................. 97

Figura 27 - Relacionamento dos Clientes - Canais........................................ 98

Figura 28 - Maximização das oportunidades do ciclo de Relacionamento Cliente-Banco ................................................................ 99



Figura 30 - Revendo a Estratégia....................................................... 103

Figura 31 - Ações de CRM sobre o Relacionamento ................................. 106

Figura 32 - Defasagem Tecnológica, Gerencial e Individual na Sociedade ........ 107

Figura 33 - Modelo de Aprimoramento contínuo: Qualidade - Continuidade ...... 109

Figura 34 - Modelo de Inovação: Inovação - Descontinuidade ........................ 109

Figura 35 - Qualidade - Inovação ..................................................... 113

Figura 36 - Ação sobre o Ciclo de Vida de Produtos ou Serviços ...................... 151

Figura 37 - Exemplo de Resultado do Teste Keirsey Temperament Sorter ....... 160

Figura 38 - Os Temperamentos: Resultado da Pesquisa ............................... 171

Figura 39 - Teste Qui-Quadrado: Sentimento/Pensamento vs. Créditos Renegociados ....................................................... 244

Figura 40 - Contribuição da Psicologia para a interpretação do conhecimento do consumidor. 


\section{LISTA DE GRÁFICOS}

Gráfico 1 - Faixa de Graduação E/I ........................................................... 167

Gráfico 2 - Faixa de Graduação S/N ...................................................... 167

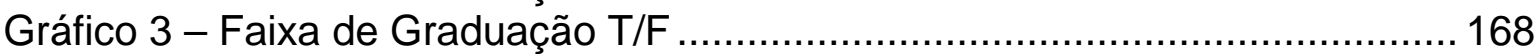

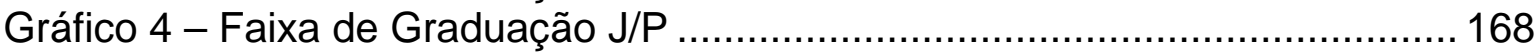

Gráfico 5 - Distribuição por Sexo ............................................................. 173

Gráfico 6 - Distribuição por Estado Civil ..................................................... 174

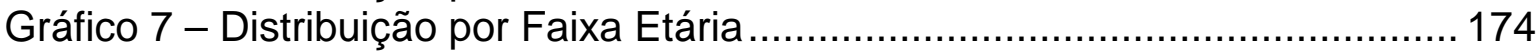

Gráfico 8 - Distribuição por Regiões Geográficas........................................... 175

Gráfico 9 - Distribuição por Tempo de Relacionamento ……………………...... 176

Gráfico 10 - Distribuição por Posse de Cartão de Crédito .................................. 176

Gráfico 11 - Utilização de Produtos Bancários ................................................... 177

Gráfico 12 - Segmentos de Cartão de Crédito................................................. 250

Gráfico 13 - Rational vs. Segmentos Cartão .............................................. 252

Gráfico 14 - Idealist vs. Segmentos Cartão ............................................... 252

Gráfico 15 - Artisan vs. Segmentos Cartão ................................................. 253

Gráfico 16 - Guardian vs. Segmentos Cartão............................................... 253

Gráfico 17 - Rationals: Volume Médio de Compras........................................... 259

Gráfico 18 - Idealists: Volume Médio de Compras …….................................. 260

Gráfico 19 - Artisans: Volume Médio de Compras............................................. 260

Gráfico 20 - Guardians: Volume Médio de Compras ........................................ 261

Gráfico 21 - Rational: Volume Médio de Rotativo .............................................2 268

Gráfico 22 - Idealist: Volume Médio de Rotativo............................................. 268

Gráfico 23 - Artisan: Volume Médio de Rotativo............................................. 269

Gráfico 24 - Guardian: Volume Médio de Rotativo ........................................... 269

Gráfico 25 - Rational: Valor de Gastos com Cartão de Crédito / Renda............. 276

Gráfico 26 - Idealist: Valor de Gastos com Cartão de Crédito / Renda ............... 276

Gráfico 27 - Artisan: Valor de Gastos com Cartão de Crédito / Renda............... 277

Gráfico 28 - Guardian: Valor de Gastos com Cartão de Crédito / Renda ........... 277

Gráfico 29 - Rational: Rotativo / Renda ......................................................... 284

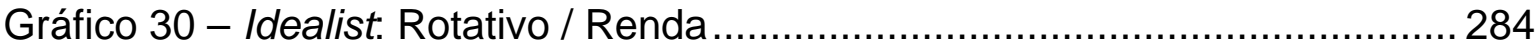

Gráfico 31 - Artisan: Idealist: Rotativo / Renda............................................. 285

Gráfico 32 - Guardian: Rotativo / Renda ...................................................... 285

Gráfico 33 - Rationals: Volume Médio de Compras....................................... 327

Gráfico 34 - Idealists: Volume Médio de Compras ............................................ 327

Gráfico 35 - Artisans: Volume Médio de Compras........................................... 327

Gráfico 36 - Guardians: Volume Médio de Compras ........................................ 327

Gráfico 37 - Rational: Valor de Gastos com Cartão de Crédito / Renda.............. 328

Gráfico 38 - Idealist: Valor de Gastos com Cartão de Crédito / Renda ............... 328

Gráfico 39 - Artisan: Valor de Gastos com Cartão de Crédito / Renda................ 328

Gráfico 40 - Guardian: Valor de Gastos com Cartão de Crédito / Renda ............ 328

Gráfico 41 - Rational: Volume Médio de Rotativo........................................... 330

Gráfico 42 - Idealist: Volume Médio de Rotativo.............................................. 330

Gráfico 43 - Artisan: Volume Médio de Rotativo ................................................. 330

Gráfico 44 - Guardian: Volume Médio de Rotativo ......................................... 330

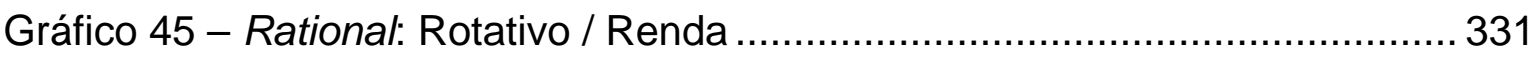

Gráfico 46 - Idealist: Rotativo / Renda ........................................................ 331 
Gráfico 47 - Artisan: Idealist: Rotativo / Renda.............................................. 331

Gráfico 48 - Guardian: Rotativo / Renda ............................................... 331 


\section{LISTA DE QUADROS}

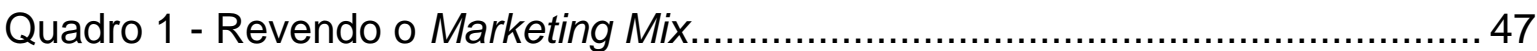

Quadro 2 - Revendo as Premissas Fundamentais do Negócio...........................63 63

Quadro 3 - Escalas medidas pelo teste Keirsey Temperament Sorter ................. 122

Quadro 4 - Características das escalas ...................................................... 122

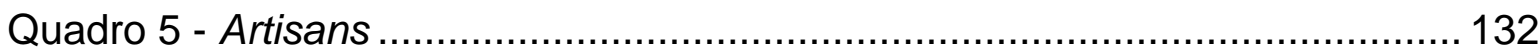

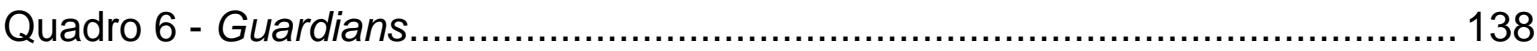

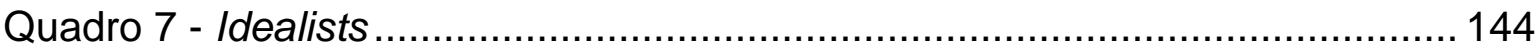

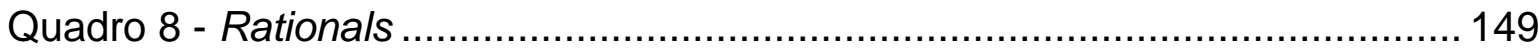

Quadro 9 - População e Amostra ............................................................. 158

Quadro 10 - Variáveis obtidas no teste Keirsey Temperament Sorter................ 163

Quadro 11 - Indicadores Utilizados ............................................................ 164

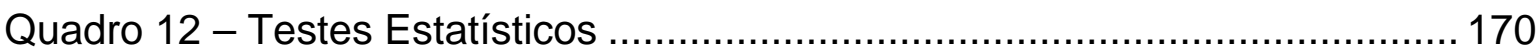

Quadro 13 - Distribuição de Freqüências Extrovertidos / Introvertidos................ 172

Quadro 14 - Distribuição de Freqüências Sensação / Intuição........................... 172

Quadro 15 - Distribuição de Freqüências Pensamento / Sentimento .................. 172

Quadro 16 - Distribuição de Freqüências Julgamento / Percepção...................... 172

Quadro 17 - Tabela Cruzada: Os 4 Temperamentos vs. Sexo ......................... 179

Quadro 18 - Teste Qui-quadrado: Os 4 Temperamentos vs. Sexo ................... 179

Quadro 19 - Tabela Cruzada: 16 tipos vs. Sexo ............................................ 180

Quadro 20 - Teste Qui-Quadrado: 16 tipos vs. Sexo..................................... 180

Quadro 21 - Tabela Cruzada: Extroversão/Introversão vs. Sexo ...................... 181

Quadro 22 - Teste Qui-Quadrado: Extroversão/Introversão vs. Sexo ................. 181

Quadro 23 - Tabela Cruzada Intuição / Sensação vs. Sexo .............................. 182

Quadro 24 - Teste Qui-Quadrado: Intuição/Sensação vs. Sexo........................ 182

Quadro 25 - Tabela Cruzada: Sentimento/Pensamento vs. Sexo ...................... 183

Quadro 26 - Teste Qui-Quadrado: Sentimento/Pensamento vs. Sexo ............... 183

Quadro 27 - Tabela Cruzada: Julgamento/Percepção vs. Sexo........................ 183

Quadro 28 - Teste Qui-Quadrado: Julgamento/Percepção vs. Sexo.................. 184

Quadro 29 - Tabela Cruzada: Os 4 Temperamentos vs. Faixa Etária................. 185

Quadro 30 - Teste Qui-Quadrado: Os 4 Temperamentos vs. Faixa Etária......... 185

Quadro 31 - Tabela Cruzada: 16 tipos vs. Faixa Etária................................... 186

Quadro 32 - Teste Qui-Quadrado: 16 tipos vs. Faixa Etária............................ 186

Quadro 33 - Tabela Cruzada: Extroversão/Introversão vs. Faixa Etária ............. 187

Quadro 34 - Extroversão/Introversão vs. Faixa Etária .................................... 187

Quadro 35 - Tabela Cruzada: Sensação/Intuição vs. Faixa Etária ..................... 188

Quadro 36 - Teste Qui-Quadrado: Sensação/Intuição vs. Faixa Etária.............. 188

Quadro 37 - Tabela Cruzada: Sentimento/Pensamento vs. Faixa Etária ........... 189

Quadro 38 - Teste Qui-Quadrado: Sentimento/Pensamento vs. Faixa Etária .... 189

Quadro 39 - Tabela Cruzada: Julgamento/Percepção vs. Faixa Etária.............. 189

Quadro 40 - Teste Qui-Quadrado: Julgamento/Percepção vs. Faixa Etária....... 190

Quadro 41 - Tabela Cruzada: Os 4 Temperamentos vs. Capitalização ............. 191

Quadro 42 - Teste Qui-Quadrado: Os 4 Temperamentos vs. Capitalização ...... 191

Quadro 43 - Tabela Cruzada: 16 tipos vs. Capitalização .................................. 192

Quadro 44 - Teste Qui-Quadrado: 16 tipos vs. Capitalização ......................... 192

Quadro 45 - Tabela Cruzada: Extroversão/Introversão vs. Capitalização ........... 193

Quadro 46 - Teste Qui-Quadrado: Extroversão/Introversão vs. Capitalização... 193 
Quadro 47 - Tabela Cruzada: Sensação/Intuição vs. Capitalização.................... 195

Quadro 48 - Teste Qui-Quadrado: Sensação/Intuição vs. Capitalização ............ 195

Quadro 49 - Tabela Cruzada: Sentimento/Pensamento vs. Capitalização .......... 196

Quadro 50 - Teste Qui-Quadrado: Sentimento/Pensamento vs. Capitalização.. 196

Quadro 51 - Tabela Cruzada: Julgamento/Percepção vs. Capitalização ............ 196

Quadro 52 - Teste Qui-Quadrado: Julgamento/Percepção vs. Capitalização .... 197

Quadro 53 - Tabela Cruzada: Os 4 Temperamentos vs. Cartão de Crédito....... 198

Quadro 54 - Teste Qui-Quadrado: Os 4 Temperamentos vs. Cartão de

Crédito............................................................................ 198

Quadro 55 - Tabela Cruzada: 16 tipos vs. Cartão de Crédito............................ 199

Quadro 56 - Teste Qui-Quadrado: 16 tipos vs. Cartão de Crédito...................... 199

Quadro 57 - Tabela Cruzada: Extroversão/Introversão vs. Cartão de Crédito ... 200

Quadro 58 - Teste Qui-Quadrado: Extroversão/Introversão vs. Cartão de



Quadro 59 - Tabela Cruzada: Sensação/Intuição vs. Cartão de Crédito ............. 201

Quadro 60 - Teste Qui-Quadrado: Sensação/Intuição vs. Cartão de Crédito..... 201

Quadro 61 - Tabela Cruzada: Sentimento/Pensamento vs. Cartão de Crédito .. 202

Quadro 62 - Teste Qui-Quadrado: Sentimento/Pensamento vs. Cartão de

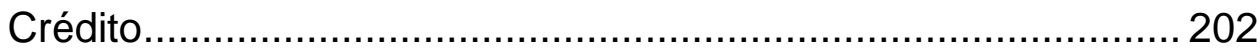

Quadro 63 - Tabela Cruzada: Julgamento/Percepção vs. Cartão de Crédito..... 203

Quadro 64 - Teste Qui-Quadrado: Julgamento/Percepção vs. Cartão de Crédito........................................................................... 203

Quadro 65 - Tabela Cruzada: Os 4 Temperamentos vs. CDB ......................... 204

Quadro 66 - Teste Qui-Quadrado: Os 4 Temperamentos vs. CDB ..................... 204

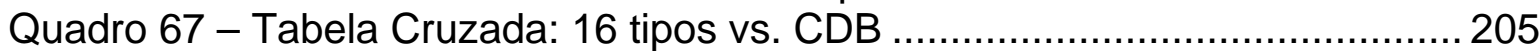

Quadro 68 - Teste Qui-Quadrado: 16 tipos vs. CDB .................................... 205

Quadro 69 - Tabela Cruzada: Extroversão/Introversão vs. CDB ...................... 206

Quadro 70 - Teste Qui-Quadrado: Extroversão/Introversão vs. CDB ................ 206

Quadro 71 - Tabela Cruzada: Sensação/Intuição vs. CDB ............................ 207

Quadro 72 - Teste Qui-Quadrado: Sensação/Intuição vs. CDB ....................... 207

Quadro 73 - Tabela Cruzada: Sentimento/Pensamento vs. CDB ...................... 208

Quadro 74 - Teste Qui-Quadrado: Sentimento/Pensamento vs. CDB............... 208

Quadro 75 - Tabela Cruzada: Julgamento/Percepção vs. CDB ......................... 209

Quadro 76 - Teste Qui-Quadrado: Julgamento/Percepção vs. CDB .................. 209

Quadro 77 - Tabela Cruzada: Os 4 Temperamentos vs Cheque Especial ......... 210

Quadro 78 - Teste Qui-Quadrado: : Os 4 Temperamentos vs Cheque

Especial............................................................................ 210

Quadro 79 - Tabela Cruzada: 16 tipos vs. Cheque Especial ......................... 211

Quadro 80 - Teste Quadrado: 16 tipos vs. Cheque Especial ........................ 211

Quadro 81 - Tabela Cruzada: Extroversão/Introversão vs. Cheque Especial .... 212

Quadro 82 - Teste Qui-Quadrado: Extroversão/Introversão vs. Cheque

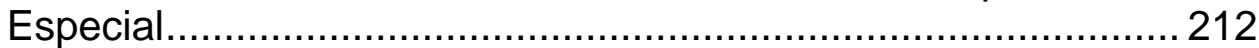

Quadro 83 - Tabela Cruzada: Sensação/Intuição vs. Cheque Especial ............. 213

Quadro 84 - Teste Qui-Quadrado: Sensação/Intuição vs. Cheque Especial ...... 213

Quadro 85 - Tabela Cruzada: Sentimento/Pensamento vs. Cheque Especial ... 214

Quadro 86 - Teste Qui-Quadrado: Sentimento/Pensamento vs. Cheque Especial........................................................................ 214

Quadro 87 - Tabela Cruzada: Julgamento/Percepção vs. Cheque Especial ...... 215

Quadro 88 - Teste Qui-Quadrado: Julgamento/Percepção vs. Cheque 
Quadro 89 - Tabela Cruzada: Os 4 Temperamentos vs. Empréstimos ............. 216 Quadro 90 - Teste Qui-Quadrado: Os 4 Temperamentos vs. Empréstimos ....... 216

Quadro 91 - Tabela Cruzada: 16 tipos vs. Empréstimos ............................... 217

Quadro 92 - Teste Qui-Quadrado: 16 tipos vs. Empréstimos ............................ 217

Quadro 93 - Tabela Cruzada: Extroversão/Introversão vs. Empréstimos........... 218

Quadro 94 - Teste Qui-Quadrado: Extroversão/Introversão vs. Empréstimos ... 218

Quadro 95 - Tabela Cruzada: Sensação/Intuição vs. Empréstimos .................... 219

Quadro 96 - Teste Qui-Quadrado: Sensação/Intuição vs. Empréstimos ............. 219

Quadro 97 - Tabela Cruzada: Sensação/Intuição vs. Empréstimos ................... 220

Quadro 98 - Teste Qui-Quadrado: Sensação/Intuição vs. Empréstimos ............. 220

Quadro 99 - Tabela Cruzada: Julgamento/Percepção vs. Empréstimos ............. 221

Quadro 100 - Teste Qui-Quadrado: Julgamento/Percepção vs. Empréstimos ... 221

Quadro 101 - Tabela Cruzada: Os 4 Temperamentos vs. Fundos de Investimentos ................................................................. 222

Quadro 102 - Teste Qui-Quadrado: Os 4 Temperamentos vs. Fundos de Investimentos ................................................................ 222

Quadro 103 - Tabela Cruzada: 16 tipos vs. Fundos de Investimentos .............. 223

Quadro 104 - Teste Qui-Quadrado: 16 tipos vs. Fundos de Investimentos........ 223

Quadro 105 - Tabela Cruzada: Extroversão/Introversão vs. Fundos de Investimentos ................................................................ 224

Quadro 106 - Teste Qui-Quadrado: Extroversão/Introversão vs. Fundos de Investimentos .................................................................. 224

Quadro 107 - Tabela Cruzada: Sensação/Intuição vs. Fundos de Investimentos ............................................................... 225

Quadro 108 - Teste Qui-Quadrado: : Sensação/Intuição vs. Fundos de Investimentos .................................................................... 225

Quadro 109 - Tabela Cruzada: Sentimento/Pensamento vs. Fundos de Investimentos ................................................................ 226

Quadro 110 - Teste Qui-Quadrado: Sentimento/Pensamento vs. Fundos de Investimentos ................................................................ 226

Quadro 111 - Tabela Cruzada: Julgamento/Percepção vs. Fundos de Investimentos ................................................................... 227

Quadro 112 - Teste Qui-Quadrado: Julgamento/Percepção vs. Fundos de Investimentos .................................................................. 227

Quadro 113- Tabela Cruzada: Os 4 Temperamentos vs. Crédito Pessoal......... 228

Quadro 114 - Teste Qui-Quadrado: Os 4 Temperamentos vs. Crédito Pessoal ...................................................................... 228

Quadro 115 - Tabela Cruzada: 16 tipos vs. Crédito Pessoal ............................. 229

Quadro 116 - Teste Qui-Quadrado: 16 tipos vs. Crédito Pessoal...................... 229

Quadro 117 - Tabela Cruzada: Extroversão/Introversão vs. Crédito Pessoal .... 230

Quadro 118 - Teste Qui-Quadrado: Extroversão/Introversão vs. Crédito Pessoal ......................................................................... 230

Quadro 119 - Tabela Cruzada: Sensação/Intuição vs. Crédito Pessoal .............. 231

Quadro 120 - Teste Qui-Quadrado: Sensação/Intuição vs. Crédito Pessoal...... 231

Quadro 121 - Tabela Cruzada: Sentimento/Pensamento vs. Crédito Pessoal ... 232

Quadro 122 - Teste Qui-Quadrado: Sentimento/Pensamento vs. Crédito Pessoal ....................................................................... 232

Quadro 123 - Tabela Cruzada: Julgamento/Percepção vs. Crédito Pessoal...... 233

Quadro 124 - Teste Qui-Quadrado: Julgamento/Percepção vs. Crédito 
Quadro 125 - Tabela Cruzada: Os 4 Temperamentos vs. Previdência .............. 234 Quadro 126 - Teste Qui-Quadrado: Os 4 Temperamentos vs. Previdência ........ 234 Quadro 127 - Tabela Cruzada: 16 tipos vs. Previdência ................................. 235 Quadro 128 - Teste Qui-Quadrado: 16 tipos vs. Previdência ............................. 235 Quadro 129 - Tabela Cruzada: Extroversão/Introversão vs. Previdência............ 236 Quadro 130 - Teste Qui-Quadrado: Extroversão/Introversão vs. Previdência.... 236 Quadro 131 - Tabela Cruzada: Sensação/Intuição vs. Previdência ................... 237 Quadro 132 - Teste Qui-Quadrado: Sensação/Intuição vs. Previdência ............. 237 Quadro 133 - Tabela Cruzada: Sentimento/Pensamento vs Previdência........... 238 Quadro 134 - Teste Qui-Quadrado: Sentimento/Pensamento vs Previdência ... 238 Quadro 135 - Tabela Cruzada: Julgamento/Percepção vs. Previdência ............. 239 Quadro 136 - Teste Qui-Quadrado: Julgamento/Percepção vs. Previdência ..... 239 Quadro 137 - Tabela Cruzada: Os 4 Temperamentos vs. Créditos Renegociados ................................................................ 240

Quadro 138 - Teste Qui-Quadrado: Os 4 Temperamentos vs. Créditos Renegociados .............................................................. 240

Quadro 139 - - Tabela Cruzada: 16 tipos vs. Créditos Renegociados................ 241

Quadro 140 - Teste Qui-Quadrado: 16 tipos vs. Créditos Renegociados........... 241

Quadro 141 - Tabela Cruzada: Extroversão/Introversão vs. Créditos Renegociados ............................................................... 242

Quadro 142 - Teste Qui-Quadrado: Extroversão/Introversão vs. Créditos Renegociados ............................................................ 242

Quadro 143 - Tabela Cruzada: Sensação/Intuição vs. Créditos Renegociados .............................................................. 243

Quadro 144 - Teste Qui-Quadrado: Sensação/Intuição vs. Créditos Renegociados ............................................................... 243

Quadro 145 - Tabela Cruzada: Sentimento/Pensamento vs. Créditos Renegociados ............................................................. 244

Quadro 146 - Tabela Cruzada: Julgamento/Percepção vs. Créditos Renegociados .................................................................. 245

Quadro 147 - Teste Qui-Quadrado: Julgamento/Percepção vs. Créditos Renegociados .................................................................. 245

Quadro 148 - Tabela Cruzada: Os 4 Temperamentos vs. Segmentos Cartão ... 251 Quadro 149 - Teste Qui-Quadrado: Os 4 Temperamentos vs. Segmentos Cartão ........................................................................... 251

Quadro 150 - Tabela Cruzada: 16 tipos vs. Segmentos Cartão ........................ 254

Quadro 151 - Teste Qui-Quadrado: As 16 tipos vs. Segmentos Cartão............. 254

Quadro 152 - Tabela Cruzada: Extroversão/Introversão vs. Segmentos Cartão ........................................................................... 255

Quadro 153 - Teste Qui-Quadrado: Extroversão/Introversão vs. Segmentos Cartão ........................................................................ 255

Quadro 154 - Tabela Cruzada: Sensação/Intuição vs. Segmentos Cartão ........ 256

Quadro 155 - Teste Qui-Quadrado: Sensação/Intuição vs. Segmentos Cartão . 256 Quadro 156 - Tabela Cruzada: Sentimento/Pensamento vs. Segmento Cartão

Quadro 157 - Teste Qui-Quadrado: Sentimento/Pensamento vs. Segmento Cartão ...................................................................... 257

Quadro 158 - Tabela Cruzada: Julgamento/Percepção vs. Segmentos Cartão . 258 Quadro 159 - Teste Qui-Quadrado: Julgamento/Percepção vs. Segmentos Cartão 
Quadro 160 - Tabela Cruzada: Os 4 Temperamentos vs. Volumes de Compras.

Quadro 161 - Teste Qui-quadrado: Os 4 Temperamentos vs. Volumes de Compras.

Quadro 162 - Tabela Cruzada: 16 tipos vs. Volume Médio Compras................ 263

Quadro 163 - Teste Qui-Quadrado: 16 tipos: vs. Volume Médio Compras ......... 263

Quadro 164 - Tabela Cruzada: Extroversão / Introversão vs. Volume Médio de Compras........................................................................ 264

Quadro 165 - Teste Qui-quadrado: Extroversão / Introversão vs. Volume Médio de Compras .............................................................. 264

Quadro 166 - Tabela Cruzada: Sensação / Intuição vs. Volume Médio de Compras........................................................................ 265

Quadro 167 - Teste Qui-quadrado: Sensação / Intuição vs. Volume Médio de Compras........................................................................... 265

Quadro 168 - Tabela Cruzada: Sentimento / Pensamento vs. Volume Médio de Compras....................................................................... 266

Quadro 169 - Teste Qui-Quadrado: Sentimento / Pensamento vs. Volume Médio de Compras ..................................................... 266

Quadro 170 - Tabela Cruzada: Julgamento / Percepção vs. Volume Médio de Compras........................................................................... 267

Quadro 171 - Tabela Cruzada: Julgamento / Percepção vs. Volume Médio de Compras........................................................................... 267

Quadro 172 - Tabela Cruzada: Os 4 Temperamentos vs. Volumes de Rotativo ....................................................................... 270

Quadro 173 - Teste Qui-Quadrado: Os 4 Temperamentos vs. Volumes de



Quadro 174 - Tabela Cruzada: 16 tipos vs. Volume Médio de Rotativo ................ 271

Quadro 175 - Teste Qui-quadrado: 16 tipos vs. Volume Médio de Rotativo....... 271

Quadro 176 - Tabela Cruzada: Extroversão / Introversão vs. Volume Médio Rotativo ...................................................................... 272

Quadro 177 - Teste Qui-quadrado: Extroversão / Introversão vs. Volume Médio Rotativo ................................................................ 272

Quadro 178 - Tabela Cruzada: Sensação / Intuição vs. Volume Médio Rotativo ....................................................................... 273

Quadro 179 - Teste Qui-quadrado: Sensação / Intuição vs. Volume Médio Rotativo .................................................................... 273

Quadro 180 - Tabela Cruzada: Sensação/Intuição vs. Volume Médio Rotativo .. 274 Quadro 181 - Teste Qui-quadrado: Sensação/Intuição vs. Volume Médio Rotativo ...................................................................... 274

Quadro 182 - Tabela Cruzada: Julgamento / Percepção vs. Volume Médio Rotativo ........................................................................ 275

Quadro 183 - Teste Qui-quadrado: Julgamento / Percepção vs. Volume Médio Rotativo .................................................................. 275

Quadro 184 - Faixas de Índice Gastos/Renda por Perfil Psicológico ................ 278

Quadro 185 - Teste Qui-Quadrado: Gastos/Renda por Perfil Psicológico.......... 278

Quadro 186 - Tabela Cruzada: 16 tipos vs. Índice Compras / Renda ................. 279

Quadro 187 - Teste Qui-quadrado: 16 tipos vs. Índice Compras / Renda .......... 279

Quadro 188 - Tabela Cruzada: Extroversão / Introversão vs. Índice Compras / Renda. 
Quadro 189 - Teste Qui-Quadrado: Extroversão / Introversão vs. Índice Compras / Renda

Quadro 190 - Tabela Cruzada: Intuição / Sensação vs. Índice Compras / Renda....

Quadro 191 - Teste Qui-Quadrado: Intuição / Sensação vs. Índice Compras / Renda.

Quadro 192 - Tabela Cruzada: Sentimento / Pensamento vs. Índice Compras / Renda.

Quadro 193 - Teste Qui-Quadrado: Sentimento / Pensamento vs. Índice Compras / Renda

Quadro 194 - Tabela Cruzada: Sentimento / Pensamento vs. Índice Compras / Renda

Quadro 195 - Teste Qui-Quadrado: Sentimento / Pensamento vs. Índice Compras / Renda

Quadro 196 - Faixas de Rotativo/Renda por Perfil Psicológico.... 286

Quadro 197 - Teste Qui-Quadrado: Faixas Rotativo /Renda por Perfil Psicológico

Quadro 198 - Tabela Cruzada: 16 tipos vs. Rotativo / Renda .......................... 287

Quadro 199 - Teste Qui-quadrado: 16 tipos vs. Rotativo / Renda ...................... 287

Quadro 200 - Tabela Cruzada: Extroversão / Introversão vs. Rotativo / Renda....

Quadro 201 - Teste Qui-quadrado: Extroversão / Introversão vs. Rotativo / Renda...................................................................... 288

Quadro 202 - Tabela Cruzada: Sensação / Intuição vs. Rotativo / Renda ......... 289 Quadro 203 - Teste Qui-quadrado: Sensação / Intuição vs. Rotativo / Renda ... 289 Quadro 204 - Tabela Cruzada: Sentimento / Pensamento vs. Rotativo/ Renda

Quadro 205 - Teste Qui-quadrado: Sentimento / Pensamento vs. Rotativo/ Renda........................................................................ 290

Quadro 206 - Tabela Cruzada: Julgamento / Percepção vs. Rotativo / Renda .. 291 Quadro 207 - Teste Qui-quadrado: Julgamento / Percepção vs. Rotativo /

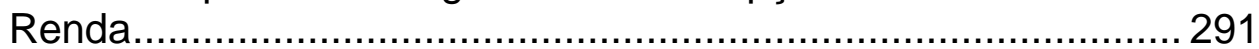

Quadro 208 - Tabela Cruzada: Investimentos em CDB vs. Graduação J-P ....... 295 Quadro 209 - Somers'd: Investimentos em CDB vs. Graduação J-P ................ 295 Quadro 210 - Tabela Cruzada: Cheque Especial vs. Graduação E-I ................ 297 Quadro 211 - Teste Somers'd: Cheque Especial vs. Graduação E-I................ 297 Quadro 212 - Tabela Cruzada: Cheque Especial vs. Graduação J-P ................ 299 Quadro 213 - Somers'd: Cheque Especial vs. Graduação J-P .......................... 299 Quadro 214 - Tabela Cruzada: Empréstimos vs. Graduação E-I ....................... 301 Quadro 215 - Somers'd: Empréstimos vs. Graduação E-I............................. 301 Quadro 216 - Tabela Cruzada: Empréstimos vs. Graduação S-N.................... 303 Quadro 217 - Somers'd: Empréstimos vs. Graduação S-N ............................. 303 Quadro 218 - Tabela Cruzada: Crédito Pessoal vs. Graduação E-I .................... 304 Quadro 219 - Somers'd: Crédito Pessoal vs. Graduação E-I ............................ 304 Quadro 220 - Tabela Cruzada: Previdência vs. Graduação E-I....................... 305 Quadro 221 - Somers'd: Previdência vs. Graduação E-I................................. 305 Quadro 222 - Tabela Cruzada: Propensão a Consumir vs. Graduação E-I........ 306 Quadro 223 - Somers'd: Propensão a Consumir vs. Graduação E-I ................. 306 Quadro 224 - Tabela Cruzada: Propensão a Consumir vs. Graduação S-N ...... 307 Quadro 225 - Somers'd: Propensão a Consumir vs. Graduação S-N ................ 307 
Quadro 226 -Tabela Cruzada: Desempenho Comercial vs. Graduação E-I....... 311 Quadro 227 - Somers'd: Desempenho Comercial vs. Graduação E-I ................. 311 Quadro 228 - Tabela Cruzada: Avaliação de Desempenho vs. Graduação E-I . 312 Quadro 229 - Somers'd: Avaliação de Desempenho vs. Graduação E-I ............. 312 Quadro 230 - Resultados das Associações.................................................... 318 


\section{INTRODUÇÃO}

São diversos os fatores que têm submetido a economia, a sociedade e o indivíduo a um freqüente e intenso ritmo de mudanças.

Dentre esses fatores destacam-se a inovação tecnológica, a globalização e a busca de novas configurações sociais e políticas cujos impactos se fazem sentir sobre a empregabilidade, estabilidade econômica, dinâmica dos mercados e o comportamento dos consumidores, entre outras variáveis.

$\mathrm{Na}$ indústria financeira de varejo o movimento não é diferente. O alto nível de volatilidade experimentado pelo setor é magnificado por ondas de fusões e aquisições, desregulamentação, desintermediação financeira e acirramento de concorrência sujeitando o setor a uma crescente pressão por ajustes e revisões do modelo de negócios.

De forma resumida, a ênfase e a solução de continuidade da indústria financeira de varejo, como também dos negócios em geral, repousa sobre a capacidade de satisfazer as necessidades dos seus clientes, merecendo como retribuição o retorno sobre os investimentos realizados.

Entretanto, a identificação das necessidades dos clientes, assim como de suas tendências, é tarefa árdua mas decisiva enquanto vantagem competitiva capaz de definir a permanência e sobrevivência num cenário de progressiva concorrência. 
O conhecimento do consumidor da indústria financeira de varejo representa assim uma variável crítica para o sucesso do setor.

Em que pese o fato de diversas áreas do conhecimento humano debruçaremse sobre o tema, aliadas ao crescente movimento de interdisciplinaridade que aproxima os diversos objetos de estudo científicos, cabe à Psicologia enquanto responsável pelo estudo dos fenômenos psicológicos, que segundo Bock, Furtado e Teixeira (1999, p.23) "referem-se a processos que acontecem em nosso mundo interno e que são construídos durante a nossa vida. São processos contínuos, que nos permitem pensar e sentir o mundo, nos comportarmos das mais diferentes formas, nos adaptarmos à realidade e transformá-la", contribuir de maneira mais significativa para a ampliação do conhecimento sobre o assunto.

Assim sendo, a presente pesquisa visa aprofundar o conhecimento sobre o consumidor da indústria financeira de varejo à luz da Psicologia e encontra-se assim estruturada:

O segundo capítulo, Canais de Distribuição Bancária, trata do cenário atual das instituições financeiras e em particular dos bancos de varejo, quando são examinados os fatores e conceitos que submetem o setor a constantes mudanças e reconfiguram sua logística de distribuição, dando novos contornos e papéis aos canais bancários, desenhando para os mesmos novas tendências que irão alicerçar o novo paradigma de distribuição bancária. 
O terceiro capítulo, Tipos Psicológicos, apresenta a teoria que trata do tema apresentando temperamentos, tipos de preferências dos indivíduos utilizados no decorrer desse estudo, buscando inseri-los no contexto financeiro.

O quarto capítulo, Questões Objeto desse Estudo, apresenta as hipóteses a serem testadas nessa pesquisa que buscam associar tipos psicológicos com o comportamento financeiro e desempenho profissional.

O quinto capítulo, Metodologia, trata dos critérios adotados para a seleção da amostra da pesquisa, composta por atendentes de um call center de uma grande instituição de varejo bancário, da aplicação nos mesmos do Keirsey Temperament Sorter e dos testes estatísticos utilizados.

O sexto capítulo, Perfil da Base, descreve os perfis demográfico e de relacionamento com o banco da amostra dos atendentes de call center da pesquisa, exibindo distribuições referentes ao tempo de relacionamento e uso de produtos e serviços bancários.

O sétimo capítulo, Associações e Correlações, expõe os resultados encontrados a partir da aplicação dos testes estatísticos que visam identificar evidências de relação entre os tipos psicológicos e comportamento financeiro dos representantes da amostra, como também com o seu desempenho profissional. 
O oitavo capítulo, Conclusões Finais, sintetiza as evidências apuradas no estudo, suas aplicações e limitações, procurando estabelecer explicações e respostas para as hipóteses formuladas.

O nono capítulo, Sugestões para Pesquisas Futuras, apresenta um conjunto não exaustivo de propostas de novos estudos que podem complementar ou derivar deste, tendo em vista a constatação de evidências encontradas que sugerem um aprofundamento dos objetos de pesquisa.

Na seqüência são exibidas as referências bibliográficas utilizadas e um anexo que contém a base de dados da amostra do estudo. 


\section{CANAIS DE DISTRIBUIÇÃO BANCÁRIA}

\subsection{Exposição do assunto}

O acirramento da concorrência resulta em incremento e melhor qualificação na oferta de produtos e serviços ao mercado consumidor, tendo como conseqüência o aprimoramento do seu nível de demanda, constituindo-se, por conseguinte em mais um aspecto a pressionar as empresas e em particular os bancos, na busca de novas soluções competitivas.

Uma das tendências é a distribuição através de outros canais. Atualmente, as agências bancárias desempenham papel central na distribuição dos serviços bancários e seguramente seguirão a sê-lo no que se refere à atribuição de relacionamento com os clientes, entretanto essa solução vem passando por uma recente revisão a partir do surgimento e consolidação de canais alternativos de atendimento e distribuição, capazes de potencializar uma nova ordenação na logística de distribuição dos bancos.

As forças motrizes dessa mudança no paradigma da distribuição bancária subdividem-se em dois vetores, caracterizados pela ótica tecnológica e pela motivação humana, que define os aspectos comportamentais.

Pela ótica tecnológica, a frenética expansão dos meios de transmissão de voz e dados em protocolos da Internet nos últimos anos, promoveu a convergência das informações que suportadas pela mobilidade trazida com os inúmeros dispositivos 
móveis portáteis como laptops, palmtops e principalmente os telefones celulares, têm causado uma verdadeira revolução no comportamento e nas relações humanas, seja na simples comunicação, como na vida profissional, no entretenimento ou na aquisição de produtos ou realização de serviços.

Pela ótica motivacional e do comportamento humano, a tecnologia inevitavelmente traz consigo inúmeras oportunidades, ampliando a visão e o conhecimento do consumidor, tornando-o naturalmente mais exigente, fazendo com que variáveis como conveniência, facilidade de uso e segurança, se tornem fatores intrínsecos à prestação dos serviços, não sendo encaradas mais como diferenciais competitivos e sim como pré-requisitos para viabilizar a expansão da utilização dos canais preferenciais de distribuição bancária.

\subsection{Objetivos}

Em conseqüência dos avanços tecnológicos, caracterizados pela convergência e pela mobilidade, presencia-se uma reconfiguração do paradigma atual de distribuição bancária.

Neste contexto, os canais de relacionamento remoto com os clientes, agora, intitulados canais preferenciais de relacionamento, representados pelas operações realizadas via Internet, Auto-Atendimento, Call Center e Mobile Banking, são responsáveis na grande maioria das instituições financeiras de varejo que atuam no país pela realização de aproximadamente $85 \%$ de todas as transações capturadas pelas mesmas, fato que demonstra a consolidação dos canais e o reconhecimento 
dos consumidores das vantagens, conveniência e segurança de se relacionar remotamente com seu banco (Febraban, 2006).

Por outro lado, a intensificação dessa dinâmica de relacionamento, realizada em sua grande parte à distância, gera um grande desafio para os bancos no sentido de que os mesmos desenvolvam soluções capazes de diferenciá-los na prestação dos serviços, buscando conciliar uma operação de custos inferiores aos do canal convencional, a agência física, com uma solução de maior interesse, conveniência e geração de valor, recompensando-os com um melhor desempenho na geração de resultado para o sistema e o cliente.

Riscos e oportunidades para o desenvolvimento de alternativas de distribuição distintas das sistemáticas convencionais não são uma prerrogativa do ambiente bancário, Kotler (1999) examina situação presente na indústria automobilística e alerta para o risco de se manter no mesmo canal de distribuição, como também para a dificuldade de se liberar do mesmo.

\subsection{Justificativa}

A busca de alternativas de distribuição, distintas do modelo convencional, compreende desafios, entretanto a fixação pelo canal convencional aprofunda a necessidade de investimentos no mesmo e pode significar a perda de oportunidade ou a abertura para o ingresso de concorrentes que poderão vir a fazer uso de outros canais de forma mais eficiente e competitiva. É necessário, portanto, manter-se atento às novas formas de distribuição, buscando abstrair-se da sistemática 
tradicional de se abordar o assunto. O desenvolvimento dos canais preferenciais de relacionamento, com visão multicanal, representa uma iniciativa nessa direção.

A expectativa desse trabalho é a de apresentar as principais questões que irão direcionar a dinâmica em torno do novo paradigma na distribuição bancária, no que tange ao que está mudando no cenário atual de distribuição bancária, porque está mudando e como deverá ser o novo cenário após as mudanças.

\subsection{Evolução de Manufaturas de Grande Volume}

Seguindo um conceito de evolução natural, as empresas têm sofrido grandes transformações nos últimos anos, decorrentes da necessidade de se adaptarem a um mercado cada vez mais competitivo e exigente caracterizado pela elevada freqüência de mudanças de paradigmas que revisitam condutas de negócio, modelos de gestão, dimensão de mercados, estágio da tecnologia, logística de distribuição, dentre diversos outros fatores determinantes da organização econômica social.

Bolwijn e Kumpe (1990) estabeleceram um modelo para explicar a evolução experimentada pelas manufaturas desde a década de 60 até a os dias atuais e concluíram que as manufaturas de grandes volumes evoluíram ao longo do citado período passando por diferentes e bastante característicos estágios de evolução durante essa jornada. 
Os autores afirmam que normalmente as empresas adquirem eficiência em seus processos produtivos para depois adquirir competitividade em termos de qualidade, rapidez, flexibilidade e inovação. Como esses processos são cumulativos, uma empresa inovadora deve ser excelente em custos, qualidade, flexibilidade e inovação. A Figura 1 - Evolução de Manufaturas de Grande Volume representa os estágios desta evolução ao longo do tempo.

Figura 1 - Evolução de Manufaturas de Grande Volume



Fonte: Bolwijn e Kumpe (1990).

A indústria bancária, por sua vez, também tem experimentado uma evolução significativa nos últimos anos, especialmente no mercado nacional.

As mudanças ocorridas nas instituições bancárias nos últimos anos possibilitam contrastá-las com o modelo de Bolwijn e Kumpe, identificando as variáveis que caracterizam a transição da empresa flexível para empresa inovadora, no ambiente bancário, tendo por base o modelo de evolução: eficiência => qualidade => flexibilidade $=>$ inovação, ressaltando-se as particularidades do setor de serviços. 


\subsection{Função Bancária e Financeira}

De acordo com Gitman (2004), "a maioria das empresas bem-sucedidas, tem necessidade permanente de fundos. Elas podem obtê-los de fontes externas de três maneiras. Uma delas é por meio de uma "instituição financeira" que receba poupanças e as transfira aos que têm necessidade de recursos. Outra é por meio de "mercados financeiros", ou seja, fóruns organizados nos quais os que ofertam e os demandantes de fundos de diversos tipos podem transacionar entre si. A terceira maneira é pelas colocações fechadas. Por causa da natureza pouco estruturada destas últimas, o foco deste estudo será as instituições e os mercados financeiros".

O autor afirma ainda que "as instituições financeiras atuam como intermediárias, promovendo a canalização das poupanças de indivíduos, empresas e órgãos de governo para empréstimos ou aplicações. Muitas dessas instituições direta ou indiretamente pagam juros pelos fundos nelas depositados; outras prestam serviços em troca de tarifas. Algumas aceitam depósitos de clientes e emprestam esse dinheiro a outros clientes ou empresas; há as que investem as economias de clientes ativos geradores de rendimentos, tais como imóveis, ações ou títulos de renda fixa. Todas as instituições financeiras são obrigadas pelo governo a atuar dentro de diretrizes regulamentadoras bem definidas".

Segundo Gitman (2004), os mercados financeiros "são fóruns nos quais os fornecedores e os demandantes de fundos podem transacionar diretamente. Enquanto os empréstimos e as aplicações pelas instituições financeiras são feitos sem o conhecimento direto dos fornecedores de fundos (poupadores), nos mercados 
financeiros eles conhecem o destino do empréstimo ou da aplicação. Os dois mercados financeiros básicos são o mercado monetário e o mercado de capitais. As transações que envolvem instrumentos de dívida de curto prazo, ou títulos negociáveis, ocorrem no mercado monetário; os títulos de longo prazo, obrigações e ações, são negociados no mercado de capitais".

As instituições financeiras participam ativamente dos mercados financeiros, como fornecedoras e como demandantes de fundos. A Figura 2- Fluxo de Intermediação Financeira, representa de forma ilustrativa, o fluxo de intermediação financeira entre tomadores e doadores de recursos.

Figura 2- Fluxo de Intermediação Financeira



Fonte: Adaptado de Savóia (2004)

\subsection{Produtos e Servicos}

De acordo com Kotler e Armstrong (2003), define-se produto como "algo que pode ser oferecido a um mercado para apreciação, aquisição, uso ou consumo e para satisfazer um desejo ou uma necessidade. Produtos são mais do que apenas 
bens tangíveis. Definidos amplamente incluem bens físicos, serviços, eventos, pessoas, lugares, organizações, idéias ou um misto de todas essas entidades".

Os autores citam que "analisando-se de forma mais ampla, os serviços são considerados como um tipo de produto essencialmente intangível que consiste em atividades, benefícios ou satisfações oferecidas à venda e que não resultam na propriedade de algo. Alguns exemplos são os serviços bancários, de hotelaria, de consultoria tributária e de reformas domésticas".

Segundo Kotler e Armstrong (2003), "os planejadores de produtos precisam pensar em três níveis de produtos e serviços. O nível mais fundamental e o produto central, que aborda a questão: O que o comprador está realmente levando? Como ilustra a Figura 3 - Os três níveis de produto, o produto central, ocupa a parte central do produto total. A mulher que compra um batom compra mais do que cor para os lábios. Charles Revson, da Revlon, percebeu isso bem cedo: "Na fábrica, fazemos cosméticos; na loja, vendemos esperança". Assim, ao projetar produtos, as empresas devem primeiramente definir o núcleo de benefícios que eles oferecerão aos compradores. Devem entender a experiência total do cliente intrínseca à compra e ao uso do produto". 
Figura 3 - Os três níveis de produto

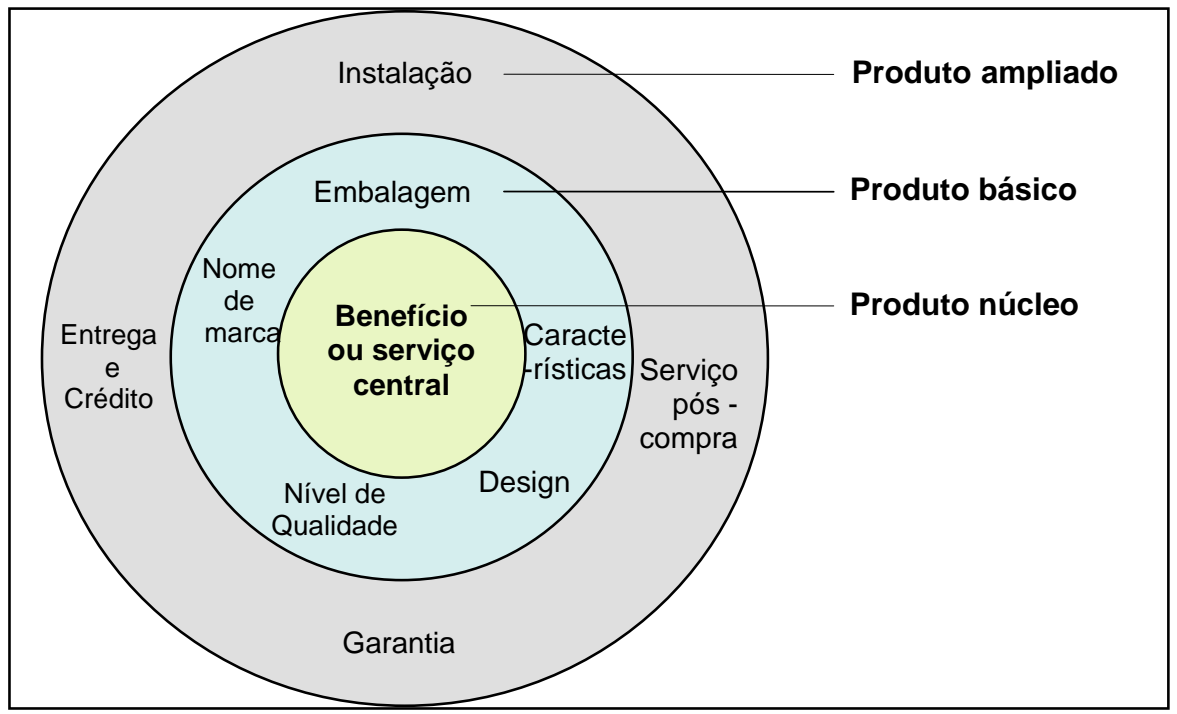

Fonte: Kotler e Armstrong (2003)

Kotler e Armstrong (2003) afirmam que em seguida "o planejador de produto deve preparar um produto "básico" ao redor do produto núcleo. Produtos básicos podem ter até cinco características: nível de qualidade, característica, design, um nome de marca e embalagem.

Por fim, o planejador de produto deve preparar um produto "ampliado" partindo dos produtos básico e núcleo, oferecendo serviços e benefícios adicionais ao consumidor.

Portanto, um produto é mais do que um simples conjunto de características tangíveis. A tendência dos consumidores é ver o produto como uma complexa conjugação de benefícios que satisfazem as suas necessidades. Ao desenvolver produtos, as empresas devem primeiramente identificar quais necessidades centrais dos consumidores serão satisfeitas por eles. Em seguida, devem projetar o produto 
básico e procurar maneiras de ampliá-lo com o intuito de criar o conjunto de benefícios que melhor satisfará os consumidores".

Kotler e Armstrong (2003) registram que "uma das maiores tendências mundiais destes últimos anos tem sido o impressionante crescimento dos serviços. Como resultado da maior riqueza, de mais tempo de lazer e do crescimento da complexidade dos produtos que requerem serviços, os Estados Unidos transformaram-se na primeira economia de serviços do mundo. Atualmente, o setor é responsável por 74 por cento do produto interno bruto norte-americano. Enquanto na década de 1970 os empregos no setor de serviços perfaziam 55 por cento do total de postos de trabalho nos Estados Unidos, em 1993 já eram responsáveis por 79 por cento do total. Os serviços estão crescendo até mais aceleradamente na economia mundial, representando um quarto do valor de todo o comércio internacional. De fato, as empresas de serviços - de bancos, seguros e comunicações, transportes, viagens e entretenimento - são responsáveis agora por bem mais de 60 por cento da economia dos países desenvolvidos em todo o mundo. Um grande número de organizações empresariais oferece serviços - companhias aéreas, bancos, hotéis, seguradoras, empresas de consultoria, escritórios de advocacia, consultórios médicos, empresas de entretenimento, empresas imobiliárias, agências de propaganda, institutos de pesquisa e varejistas, entre outras".

Uma empresa deve considerar quatro características especiais do serviço ao elaborar seus programas de marketing: intangibilidade, inseparabilidade, 
variabilidade e perecibilidade. Essas características estão resumidas na Figura 4 Quatro características dos serviços.

Figura 4 - Quatro características dos serviços

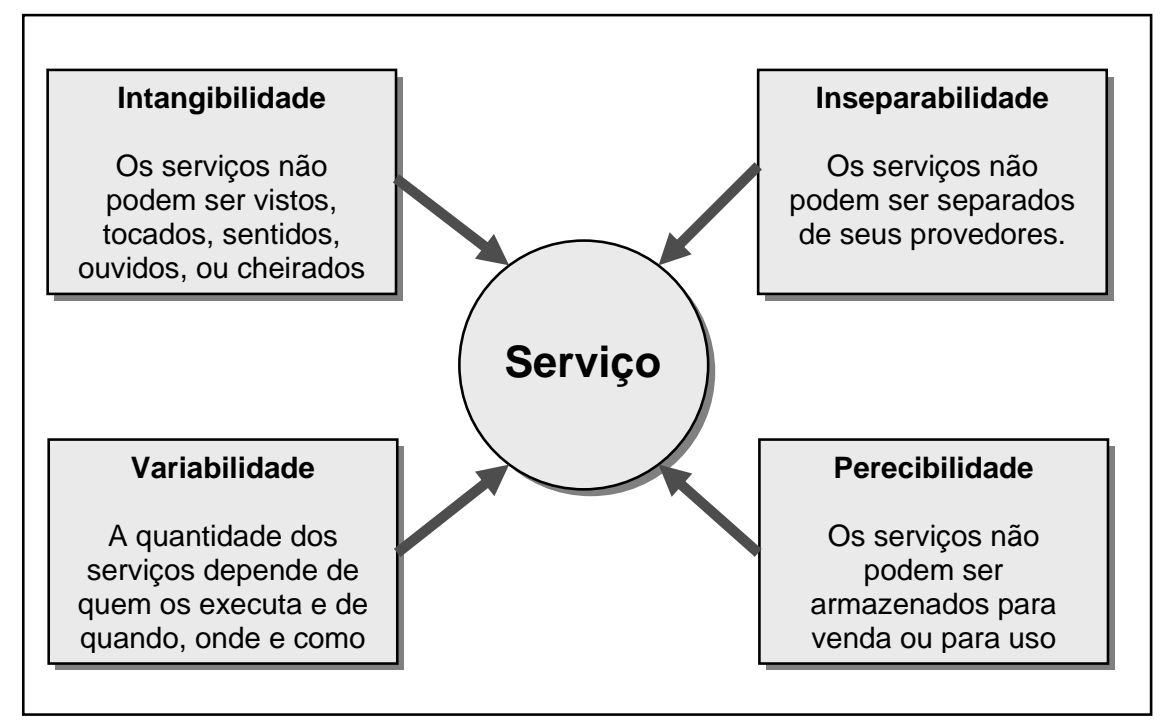

Fonte: Kotler e Armstrong (2003)

Exatamente como as empresas manufatureiras, Kotler e Armstrong (2003) observam que "as boas empresas prestadoras de serviços usam o marketing para conseguir um forte posicionamento nos mercados-alvo selecionados".

No entanto, os autores complementam que "como os serviços são diferentes dos produtos tangíveis, muitas vezes eles exigem abordagens de marketing adicionais. No caso de uma empresa fabricante de produtos, eles são razoavelmente padronizados e podem ficar nas prateleiras à espera dos consumidores. Mas no caso de prestadoras de serviço, o cliente e o empregado da linha de frente interagem no momento da execução do serviço. Por isso, as prestadoras de serviços têm de interagir efetivamente com seus clientes para criar valor superior durante a realização deles. Interação efetiva, por sua vez, depende da capacidade dos 
empregados da linha de frente e dos processos de produção e de apoio aos serviços que Ihes dão sustentação".

\subsection{Vantagem Competitiva}

O exame da questão da competitividade tem particular interesse para o presente trabalho em razão de que a tecnologia desempenha no setor de serviços bancários, assim como em todo o ambiente empresarial, uma função de elevado conteúdo competitivo, sendo responsável pela criação de inúmeras oportunidades de negócios no setor, atuando sobre custos, acirrando a disputa no mercado, ampliando o próprio limite do mercado e propiciando o ingresso de novos agentes no cenário já bastante disputado.

A competitividade entre empresas é um fator fundamental para o sucesso. Segundo Porter (1986), "são cinco as forças competitivas básicas que determinam potencial de lucro final da empresa, avaliado em termos de taxa de retorno a longo prazo sobre o capital investido. São elas:

- Ameaça de Entrada: considera a possibilidade de ingresso no mercado de novas empresas;

- Intensidade da rivalidade entre os concorrentes existentes: a rivalidade entre as empresas afeta a rentabilidade das mesmas;

- Pressão dos produtos substitutos: os substitutos reduzem os retornos potenciais da empresa, limitando os preços fixados pela mesma;

- Poder de negociação dos compradores: o resultado da empresa é afetado na medida em que os compradores pressionam preços, exigem qualidade e atuam sobre os concorrentes da empresa; 
- Poder de negociação dos fornecedores: a dependência em relação a fornecedores pode ter reflexos em preços e qualidade dos bens e serviços fornecidos".

As cinco forças competitivas descritas por Porter (1989), são responsáveis pelo resultado da empresa, sendo necessário para a mesma criar e sustentar uma vantagem competitiva que surge quando a empresa é bem sucedida na criação de valor para os seus compradores, que supera o seu custo de fabricação. De acordo com o autor "O valor é aquilo que os compradores estão dispostos a pagar, e o valor superior provém da oferta de preços mais baixos que os da concorrência por benefícios equivalentes ou do fornecimento de benefícios singulares que mais do que compensam um preço mais alto".

Segundo Porter (1980), "as estratégias podem ser classificadas em três categorias: diferenciação, liderança por meio do custo e foco".

A estratégia de "diferenciação" segundo o autor, "consiste em projetar uma forte identidade própria para o serviço ou produto, que o torne nitidamente distinto dos produtos e serviços concorrentes. Isso significa enfatizar uma ou mais vantagens competitivas, como qualidade, serviço, prestígio para o consumidor, estilo do produto ou aspecto das instalações". O autor (op.cit) cita como exemplo:

- "O McDonalds enfatiza a qualidade uniforme de seus produtos, rapidez do atendimento, limpeza e higiene das instalações e da preparação de refeições. 
- A Montblanc enfatiza a exclusividade e o prestígio de seus clientes; a Bic enfatiza a praticidade".

O autor (op.cit) complementa ainda que "na estratégia da busca de "liderança por meio do custo", o objetivo não é diferenciar-se dos concorrentes, mas oferecer um produto ou serviço mais barato. Essa estratégia é largamente utilizada pelos fabricantes de computadores, à medida que a tecnologia torna os produtos muito semelhantes e barateia os componentes. Também foi a estratégia usada pelos fabricantes japoneses de automóveis e relógios digitais, que destruíram o mito de que qualidade superior significa preço mais alto. E quem quer que use um relógio Ironman deixou-se convencer pela mesma estratégia, usada pela Texas Instruments".

Brunstein (2005) acrescenta que "a natureza, a constituição e o comportamento dos custos em relação ao nível de atividades e seu ótimo técnico são aspectos essenciais da rentabilidade dos produtos e elementos-chave na competitividade das empresas".

Segundo Porter (1980), “a estratégia do "foco" (também chamada de estratégia de concentração ou do nicho) consiste em escolher um nicho ou segmento do mercado e concentrar-se nele. Quando adota a estratégia do foco, a empresa procura dominar os recursos para explorar o nicho escolhido da melhor forma possível, ao invés de procurar enfrentar todos os concorrentes no grande mercado. A estratégia, portanto, é ser o melhor e tirar o máximo proveito de mercados ou produtos e serviços selecionados de forma estreita". 
Segundo Kotler e Armstrong (2003), "nesta época de intensa concorrência de preços, as empresas de serviços reclamam da dificuldade de criar uma diferenciação entre seus serviços e os de seus concorrentes. Na proporção em que consideram semelhantes os serviços prestados por diferentes empresas, os clientes se preocupam menos com o prestador de serviços do que com o preço".

Os autores (op.cit) mencionam que "a solução para a concorrência de preços é o desenvolvimento de oferta, entrega e imagem diferenciadas. A oferta pode incluir características inovadoras que a destacam das ofertas dos concorrentes. Por exemplo: as companhias aéreas introduziram inovações como filmes e serviço telefônico a bordo, reserva antecipada de lugares e programas de milhagem para diferenciar suas ofertas. A British Airwaiys até oferece a seus passageiros internacionais uma cabine para dormir, chuveiro com água quente e cafés da manha diferenciados".

Kotler e Armstrong (2003) ressaltam que "as empresas prestadoras de serviços também podem diferenciar a entrega de seus serviços contratando pessoas mais qualificadas e confiáveis para executá-los, desenvolvendo um ambiente físico de qualidade superior para a entrega do produto ou serviço ou elaborando um processo de entrega superior. Por exemplo: muitos bancos oferecem a seus clientes o homebanking eletrônico, indubitavelmente um método muito melhor de usufruir dos serviços bancários sem ter de dirigir e estacionar um carro e esperar na fila".

Por fim, os autores (op.cit) complementam que "as empresas prestadoras de serviços também podem batalhar para diferenciar suas imagens por meio de 
símbolos de construção de marca. Por exemplo: O Harris Bank de Chicago adotou o leão como seu símbolo nos papéis que usa, nas campanhas publicitárias e até mesmo nos animaizinhos de pelúcia com que presenteou os novos correntistas. O bem conhecido leão do Harris confere ao banco uma imagem de força".

Segundo Levitt (1980), "não existe commodity. Todo bem e serviço é diferenciável. Embora a percepção comum seja de que isso vale mais para bens de consumo do que para bens e serviços industriais, o oposto é realidade. Em bolsas de commodities, corretores de metais, grãos e carcaça suína negociam artigos genéricos, totalmente indiferenciados. Mas o que "vendem" é a alegada distinção de sua execução - a eficiência de transações em nome do cliente, a pronta resposta a solicitações, clareza e a velocidade de confirmações e por aí afora. Em suma, o produto oferecido é diferenciado, embora o produto genérico seja idêntico".

Levitt (1980) conclui que o "valor que o cliente atribui ao produto é proporcional a sua suposta capacidade de resolver um problema ou satisfazer uma necessidade. Todo o resto é secundário".

\subsection{A Economia Digital}

A humanidade tem assistido recentemente, com uma freqüência crescente, uma quantidade gigantesca de mudanças tecnológicas. Tomando por referência a capacidade humana de locomoção, Palazzo (1993), observa ter sido a velocidade de deslocamento do ser humano, limitada pela tração animal por milhões e milhões de anos. Entretanto, em menos de 150 anos com o advento do trem sucedido pelo 
automóvel, avião e foguete, a velocidade de deslocamento saltou de $30 \mathrm{~km} / \mathrm{h}$ para $30.000 \mathrm{~km} / \mathrm{h}$.

Ao analisar o impacto sobre a capacidade de transmissão de mensagens, complementa o autor que no século passado, a mesma também se encontrava limitada pela tração animal quando se conceituava "o tamanho de uma comunidade em função do espaço percorrido pela notícia, desde o nascer até o pôr-do-sol".

Estabelecendo-se um paralelo entre os novos limites de velocidade experimentados nesse século pela capacidade de deslocamento humano e a capacidade de transmissão de mensagens, o autor relata que enquanto uma variou de $30 \mathrm{~km} / \mathrm{h}$ para $30.000 \mathrm{~km} / \mathrm{h}$, a outra saltou do mesmo patamar inicial para 300.000 km/s, tendo como conseqüência imediata a ampliação do "tamanho da comunidade" com o surgimento da globalização.

Conforme resume Savóia (1996), entende-se globalização como sendo "um fenômeno recente iniciado na década de 80, configurando-se como uma etapa posterior à internacionalização da economia, aonde ocorre a integração da produção de bens, serviços e dos fluxos de capital a nível mundial, gerando interdependência entre as organizações e os países".

Cumpre destacar que num intervalo de tempo muito curto, equivalente a aproximadamente duas gerações humanas, romperam-se diversos paradigmas com conseqüências significativas sobre a sociedade, do ponto de vista da 
competitividade empresarial surgiram diversas oportunidades tendo a mesma se acirrado sobremaneira.

A evolução e a adoção de novas tecnologias emergentes, aliadas ao processo de globalização, têm sido fatores preponderantes que atuam como agentes de mudança no comportamento da sociedade atual.

Segundo Davis e Meyer (1999), "a infra-estrutura digital construída ao longo dos últimos anos possibilitou que se tornasse realidade a conexão entre: pessoas, máquinas e organizações, por meio das mais variadas combinações a qualquer tempo, e em qualquer lugar".

De acordo com Airbar apud Costa (2004), "a tecnologia é uma das fontes mais importantes que promove as mudanças sociais". Salienta que uma importante tendência é observada a partir de 1994, podendo ser chamada de determinismo tecnológico, onde a idéia de que uma nova era de negócios, caracterizada por uma velocidade e complexidade sem precedentes, ocorreria com a introdução de uma nova tecnologia e tudo mudaria da noite para o dia, independente do valor criado para a sociedade.

Costa (2004) menciona ainda que "O termo determinismo tecnológico foi criado pelo sociólogo americano Veblen apud Chandler (1995) e os defensores desta teoria abraçam a idéia de que o desenvolvimento tecnológico molda a sociedade, sem, contudo, ser influenciado por ela. Ele existe fora da sociedade, entretanto, influencia a mudança social". 
Para Negroponte (1995) a natureza física constituída de átomos, passa a ser transmitida e "transformada" em outra natureza, a natureza digital (bits), ("É o menor elemento atômico no DNA da informação"). Como não é baseada em matéria física, a informação em bits pode ser transmitida cada vez mais em um tempo e espaço menor, ultrapassando os limites da informática e estando cada vez mais presente na vida dos seres humanos.

De acordo com o Negroponte (1995), "haverá uma interação maior entre os humanos de todos os lados do mundo, compartilhando idéias e isso de uma forma cada vez mais dinâmica. Assim como grandes computadores transformaram-se hoje em laptops e palmtops que podem ser carregados até em bolsos. Além disso, será cada vez maior a interatividade e o mundo digital irá se adaptar a quem o serve, sendo cada vez mais personalizado".

Segundo Negroponte (1995) a economia pode estar caminhando rumo a uma economia da informação, mas deve-se medir o comércio e fazer-se seus balanços pensando em termos de átomos.

Negroponte (1995) falava há doze anos atrás com extrema naturalidade, sobre temas relacionados à era digital que se presenciam hoje de maneira corriqueira em residências, escritórios e na comunidade em geral:

Segundo o autor (op.cit), "A superestrada da informação nada mais é do que o movimento global de bits sem peso à velocidade da luz. Um conteúdo inteiramente 
diverso emergirá dessa digitalização, assim como novos jogadores, novos modelos econômicos e provavelmente, uma indústria caseira da informação e do entretenimento. Á medida que o mundo dos negócios for se globalizando e a Internet crescendo, começaremos a ver um espaço digital contínuo de trabalho". (Negroponte, 1995,:p. 23; 216; 218).

Negroponte (1995), afirmou que "assim como a uma força da natureza, a era digital não poderá ser negada ou detida e disporá de quatro principais características que determinarão o seu triunfo final: a descentralização, a globalização, a harmonização e a capacitação".

Ao se estabelecer um paralelo entre a visão de futuro trazida por Negroponte e os principais desafios citados por Nóbrega (2001), ao afirmar que "a evolução das tecnologias representa a evolução do pensar humano, num esforço para criar organizações mais eficientes e inventar formas de superar obstáculos, sendo o tempo e o espaço as dificuldades mais prementes de serem vencidas", observa-se que os mesmos já não são mais impeditivos para as organizações, pelo menos em determinados nichos, predominantemente digitais.

\subsection{Mercado Virtual}

Os ambientes virtuais estão pressionando cada vez mais a estrutura das empresas e a informação, matéria prima do conhecimento, o que conseqüentemente assume um caráter essencial na inserção de novas funcionalidades interativas presentes nas trocas e transações realizadas nesse ambiente. 
A criação de espaços inteligentes começa a surgir em decorrência da provisão e distribuição de informações através de uma rede que permite que seus interlocutores possam interagir em esfera global, onde sua composição é, total ou parcialmente, composta por agentes artificiais autônomos como, webbots, shopbots e robôs.

$\mathrm{Na}$ perspectiva de Carley (2002), "os espaços inteligentes possuem as seguintes características:

a) Acesso Simultâneo: agentes, humanos ou artificiais, acessam ou provêm informações quando e onde seu uso for necessário;

b) Escala: grande volume de informações automaticamente selecionado, coletado e armazenado por um vasto número de agentes;

c) Cognição e Inteligência Distribuída: a capacidade de acesso, processamento e difusão de informações estará distribuída através de agentes, dispositivos físicos e meios de comunicação;

d) Computação Invisível: a nanotecnologia e o crescente número de satélites de órbita baixa têm possibilitado transferir a capacidade dos computadores para um crescente número de diferentes dispositivos físicos, aproximando a interface entre o mundo digital e o analógico.

A criação de espaços inteligentes aumenta o tamanho e complexidade das relações, especialmente ampliadas pela interação entre agentes que tem habilidade para aprender, adaptar e evoluir enquanto grupo".

Em termos práticos, nos mercados virtuais, o desenvolvimento de idéias atingiu uma velocidade sem precedentes, criando uma necessidade por rapidez e 
eficiência, dificilmente alcançada por indivíduos e organizações que não assimilem a perspectiva de melhorar sua performance ao combinar seu trabalho com o de outros (Subramani e Rajagopalan, 2003, Carley, 2002).

Estabelecendo-se um paralelo com o potencial dos mercados virtuais em esfera global, em 2006, o comércio eletrônico no Brasil, apresentou crescimento de $35 \%$ em relação ao ano anterior, totalizando 13,3 bilhões de reais em vendas no varejo on line, o que representa $3,5 \%$ do varejo no Brasil, de acordo com dados do IBGE, (Instituto Brasileiro de Geografia e Estatística).

Segundo dados divulgados pela comScore apud Ciashop (2007) "em contraste com esses dados, o varejo on line nos Estados Unidos encerrou o ano de 2006 com faturamento de 100 bilhões de dólares, crescimento de 24\% em relação ao ano anterior. Como o internauta não tinha a necessidade de enfrentar o período de festas em lojas e shoppings superlotados, o período de compra se estendeu por mais tempo e gastou mais".

Os indicadores brasileiros são modestos se comparados aos norte americanos, porém, demonstram um claro sinal de que o usuário de internet brasileiro está amadurecendo rapidamente. Segundo balanço divulgado pelo Ibope/NetRatings em dez/06, o Brasil acaba de atingir o novo recorde de usuários residenciais ativos na internet, com 14,5 milhões de internautas. O estudo aponta também, que mesmo com a queda de 26 minutos no tempo médio mensal navegado, o Brasil manteve a liderança entre os usuários que mais acessam a internet em casa, com média de 20 horas e 4 minutos por internauta. 
A França aparece na segunda posição, com 19 horas e 30 minutos, seguido pelos Estados Unidos, com 18 horas e 10 minutos, e Espanha, com 17 horas e 54 minutos.

Esses dados demonstram o enorme potencial que o comercio eletrônico possui no Brasil. Ao se realizar um paralelo com o mercado convencional, mais especificamente analisando-se o comportamento dos consumidores paulistanos que freqüentam Shopping Centers, segundo a Associação Brasileira de Shopping Centers (Abrasce), somente a cidade de São Paulo, conta atualmente com 41 shoppings, que atraem mensalmente, 40 milhões de consumidores.

Atualmente, praticamente todos esses Shoppings, estão passando por grandes reformulações conceituais, cujas novas tendências, diferem em muito dos projetos da década de 90, cujo foco era de criar corredores estreitos com iluminação artificial, de modo que os consumidores uma vez lá dentro, perdessem a noção da hora. Hoje os shoppings, muito mais do que centros de compras, em função de suas características de comodidade, conforto e segurança, privilegiam a questão da realização dos mais variados tipos de serviços que vão desde possibilitar um simples corte de cabelo, freqüentar aulas de ginástica e teatro à realização de exames laboratoriais. Observando-se ainda que a grande tendência do momento fica por conta da parte de entretenimento, onde as salas de cinema e enormes teatros ganham cada vez mais espaço nos shoppings paulistanos. 
Esses dados foram divulgados em matéria da revista veja (2006) indicando inclusive que, o Brasil está seguindo uma nova tendência, muito em voga nos Estados Unidos, cujas características arquitetônicas dos shoppings privilegiam a amplitude e a iluminação natural, conforme menção na matéria, "A tendência agora é tentar reproduzir dentro do shopping a sensação de liberdade e espaço que o consumidor enfrenta na rua, com a vantagem da segurança e do ar-condicionado".

É nesse contexto que, seguindo a percepção dos consumidores norteamericanos, o comércio eletrônico pode tirar grande proveito, pois pode ser encarado, não como um mercado concorrente à estrutura de comércio convencional, mas sim como um grande aliado que possibilitará aos consumidores, maior comodidade e horário estendido para realização de suas compras, podendo então aumentar seu tempo disponível para usufruir das novas funcionalidades disponíveis nos shopping centers com objetivo de diversão e entretenimento.

Além disso, quanto maior o hábito de consumo nos canais eletrônicos, maior o conhecimento adquirido pelas empresas dos respectivos públicos e segmentos, o que favorece a criação de ofertas customizadas, que além de fidelizar, agregam valor elevando a satisfação e a credibilidade, conseqüentemente, elevando os ganhos.

\subsection{Banco Virtual - O Banco Móvel sem agências}




\subsection{1 $\underline{\text { Conceito }}$}

Considera-se o Banco Virtual como uma proposta de atendimento personalizado e distribuição de serviços bancários e não bancários, que busca através de um ferramental tecnológico utilizado por um quadro treinado e capacitado a interagir transacional e negocialmente, proporcionar a maior conveniência possível e gerar maior valor à relação cliente-banco, visando a superação das dificuldades que derivam da minimização do contato físico, que por sua natureza é incrementador do potencial para a realização de negócios e fidelização da base de clientes; candidatando-se a ser um aliado potencial e econômico-financeiramente viável da agência convencional na estratégia de distribuição bancária.

A Figura 5 - Consolidação do Banco Virtual apresenta a proposta na qual se projeta o objetivo de capacitá-lo a desempenhar com a mesma eficiência da central de atendimento no que tange ao ambiente transacional e cumulativamente desempenhar eficientemente o papel de realizador de negócios, como ocorre potencialmente no ambiente das agências convencionais, onde o contato físico propicia o relacionamento e a conseqüente oportunidade de se desenvolver negócios com maior poder persuasivo e probabilidade de sucesso. 
Figura 5 - Consolidação do Banco Virtual

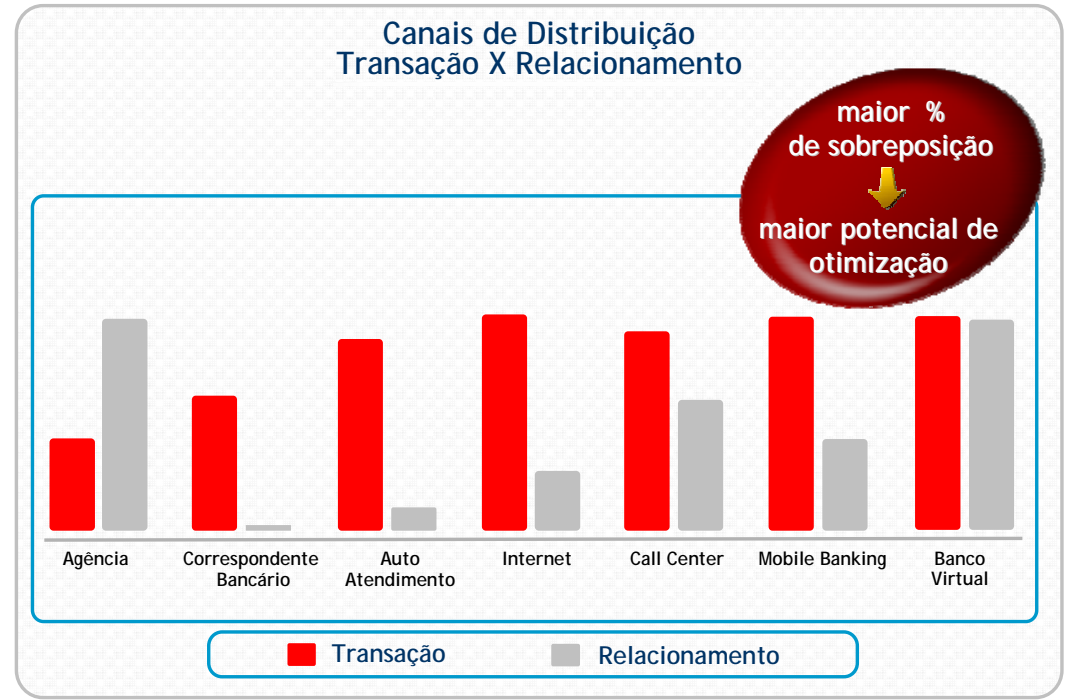

Dessa maneira, o Banco Virtual posiciona-se como canal que busca apresentar uma solução verticalizada de distribuição de serviços bancários e não bancários, postulando, por conseguinte uma condição de destaque no composto de distribuição dos bancos.

\subsubsection{Gestão do relacionamento com o Cliente}

No setor financeiro o benchmark para a mensuração do relacionamento com o cliente é a administradora de cartões de crédito. Esta dinâmica foi concebida de maneira bastante simplificada, fato que confere a essa sistemática facilidade no processo de comunicação com os clientes, uma vez que a variável básica utilizada como métrica da relação cliente-cartão é o pagamento da fatura das despesas que o cliente realiza com o cartão, sendo também utilizado, em alguns programas, o pagamento da tarifa de anuidade do cartão.

No caso dos bancos, o relacionamento do cliente-banco se expressa de forma complexa, uma vez que o cliente tem à sua disposição inúmeros serviços com 
processos e configurações para formação de resultados bastante diferenciados, podendo se apresentar como simples prestação de serviços, operações ativas ou passivas, resultando em maior dificuldade de apuração de sua margem de contribuição individual, como também na tradução dessa medida de relacionamento banco-cliente de maneira simples.

Entretanto, o poder de fidelização e retenção de clientes, resultante de um programa bem estruturado de reconhecimento de relacionamento, justifica o desafio da transposição do modelo desenvolvido no ambiente de cartões de crédito para o ambiente do banco comercial, em que pese o fato de que há dificuldades a serem superadas, tanto no caso da apuração quanto na comunicação, para os clientes da proxy que representa a métrica do relacionamento cliente-banco.

A observação dos movimentos bem sucedidos realizados fora do ambiente bancário e a avaliação da possibilidade de sua transposição para o mesmo demonstram a necessidade dos bancos de acompanharem modelos de negociação e gestão externos à sua atividade tradicional que através de processos de desintermediação e desregulamentação acabam por se manifestar potencial e diretamente em sua atividade principal, reiterando a idéia de que há outros benchmarks que não somente bancos na indústria bancária.

A gestão de relacionamento visa ser uma sistemática de reconhecimento da preferência que o cliente dedica ao banco, buscando desempenhar o papel de atração, retenção e fidelização do cliente à instituição, cuja dinâmica pode ser sumarizada segundo a Figura 6 - Dinâmica da Gestão de Relacionamento. 
Figura 6 - Dinâmica da Gestão de Relacionamento



Observa-se que há o propósito de se estabelecer um transparente canal de comunicação no qual se definem de maneira objetiva os eventos de maior valorização, ou seja, pontuação, como também os benefícios disponíveis em função da pontuação obtida.

Dessa forma a gestão de relacionamento se caracteriza como processo "vivo", procurando acompanhar a dinâmica do mercado e das relações clientebanco.

A gestão de relacionamento permite ao banco a apuração individualizada da relação cliente-banco. Essa medida é extremamente valiosa uma vez que permite orientar as ações de marketing one-to-one, indicando o enfoque correto para cada tipo de cliente e a abordagem com maior probabilidade de sucesso no sentido de se despertar a motivação do cliente e estimular seu comportamento. 
O adequado armazenamento das pontuações obtidas pelos clientes, seu detalhamento e evolução constituem um valioso database marketing que alicerça as ações de incremento de relacionamento e conseqüente fidelização.

A dinâmica de funcionamento da gestão de relacionamento, apresentada de maneira sumarizada na Figura 6 , sugere o desenvolvimento modularizado e customizado de serviços financeiros e benefícios exclusivos para determinados nichos, amparando uma abordagem segmentada e específica de mercado.

Essa flexibilidade na concepção do serviço permite à instituição uma maior rapidez e adequação às condições de mercado, permitindo a exploração das oportunidades de segmentação com custos de desenvolvimento reduzidos, em função da arquitetura modularizada do processo, resultando em vantagem competitiva necessária para diferenciar-se no acirrado cenário econômico.

\subsubsection{Organização do Banco Virtual}

O Banco Virtual deve operar como uma "agência independente", possuindo contabilidade distinta das outras agências convencionais e reforçando sua característica de complementaridade na busca de novos clientes minimizando conflitos de interesse com a base existente do banco.

A estrutura comercial sugerida é dividida em dois grandes grupos: Gerentes de Operações e Gerentes de Negócios. 
Observe-se que a função principal do gerente de operações é o de administrar o processo de abertura de conta corrente, sendo essa operação apartada da gestão das contas já abertas, fato que se constitui numa especialização por função, à semelhança do que ocorre na indústria de cartão de crédito, na qual as atividades de venda de cartões e a de manutenção da carteira são independentes e desempenhadas por diferentes áreas e indivíduos.

Já na agência convencional, os procedimentos de abertura e manutenção de contas correntes são realizados pelo mesmo responsável, o gerente da agência.

O segundo grupo que compõe a equipe comercial do Banco Virtual é o de gerente de negócios, a ele cabe o atendimento e administração dos clientes. O exercício de sua função se dá na sede do Banco Virtual que pode se localizar em local menos oneroso por não ter visibilidade para o cliente, ainda que raramente visitado por alguns deles.

O gerente de negócios deve ter um sólido treinamento, tanto técnico quanto comercial, visto que sobre ele repousa a responsabilidade de buscar superar a limitação de não ter contato físico com o cliente para a realização de negócios.

O processo de formação dos recursos humanos é extremamente facilitado numa plataforma na qual se tem condições de acompanhar o histórico de desenvolvimento comercial dos envolvidos, resultando em profissionais melhor monitorados, para os quais se faculta um processo de aprendizagem acelerado e mais eficaz, apoiando e facilitando a identificação de ações de caráter motivacional. 
O gerente de negócios, em função de não conhecer pessoalmente o cliente depende também do desenvolvimento de uma ferramenta que procure complementar dados a respeito do mesmo para ampará-lo no momento do atendimento, considerando-se o fato de que o cliente pode ser atendido por qualquer gerente.

\subsubsection{Proposta de Segmentação Lógica do Mercado}

O Banco Virtual deve apresentar uma solução inovadora de abordagem de mercado. Para tanto precisa conjugar os seguintes fatores:

- Cartões de crédito como benchmark: oferece à operação mecanismos poderosos de atração, fidelização e retenção de seus clientes, facultandoIhe uma abordagem diferenciada de mercado;

- Gestão de relacionamento: ferramenta flexível e modularizada, cuja construção do sistema permite o desenvolvimento de atributos específicos e em princípio exclusivos para determinados nichos de mercado;

- Canal alternativo virtual: Pode potencializar o uso da abordagem diferenciada para distribuir serviços bancários de uma forma economicamente viável;

Os três fatores mencionados capacitam o Banco Virtual a transferir para o ambiente bancário uma solução de abordagem de nichos diferenciada. 
A gestão de relacionamento do Banco Virtual deve inspirar-se assim na lógica de abordagem de mercado da indústria de cartão de crédito procurando atribuir maior valor à relação cliente-banco.

Observa-se que os mesmos gerentes podem atender diferentes nichos, considerando-se que as facilidades descritas Ihes permitem a identificação da origem e o conhecimento das características de cada um dos nichos;

Assim sendo, o Banco Virtual apresenta uma solução que viabiliza uma abordagem de nichos mais focados e menores quando comparada ao poder do banco convencional de viabilizar economicamente esses nichos.

A utilização de mecanismo controlador da métrica de relacionamento do Banco Virtual com os nichos abordados possibilita conceder aos mesmos benefícios específicos e exclusivamente desenhados, tomando-se por base a capacidade do relacionamento moldar-se de forma flexível e modularizada a cada nicho para o qual se deseja conferir molduras singulares.

A alternativa de abordagem de mercado apresentada pelo Banco Virtual resulta numa proposta inédita de segmentação lógica que se ampara na solução virtual de distribuição para viabilizar a customização de tratamento de segmentos de mercado.

Em razão de sua plataforma tecnológica, o Banco Virtual está capacitado a oferecer uma solução de segmentação de mercado diferenciada no ambiente virtual, 
pelo fato de seus gerentes poderem receber treinamento especialmente customizado para suas necessidades, sendo possível que os mesmos atendam, de forma teoricamente ilimitada, clientes pertencentes a diversos nichos de mercado.

Essa vantagem competitiva confere ao Banco Virtual a capacidade de atuar num número praticamente ilimitado de segmentos tirando proveito da economia de escala característica de sua sistemática de operação. Trata-se da oportunidade de se alcançar a customização combinada com uma redução de custos em função da escala do processo, fato que resulta numa combinação poderosa a ser explorada mercadologicamente.

\subsubsection{Valores do Banco Virtual}

\subsubsection{Valores Mercadológicos}

O Banco Virtual visa expandir os negócios do banco, buscando o crescimento de sua base de clientes, de maneira a complementar o mercado atendido por sua rede atual.

O público alvo desejado pelo Banco Virtual é formado por pessoas que valorizam o fator tempo. Esse grupo está normalmente presente em grandes metrópoles nas quais o processo de locomoção encontra-se progressivamente dificultado pelo tráfego e demais aspectos, tais como segurança que acabam por incrementar a dimensão desse grupo, demandando das instituições bancárias uma ação cada vez mais premente para com esse nicho em crescimento, fato que se constitui numa oportunidade singular de mercado. 
Enquanto a agência tradicional funciona, na maior parte das praças, das 10 às 16 horas, isto é, durante seis horas, nos dias úteis; o Banco Virtual pode operar, com atendimento personalizado, de maneira ininterrupta.

\subsubsection{Valores Econômico-Financeiros}

O Banco Virtual busca oferecer uma alternativa de distribuição de serviços bancários, na qual se experimenta um significativo potencial para economia de escala.

É interessante frisar que a redução de custo de transação por mídia está inversamente correlacionada com o incremento do conteúdo tecnológico de cada canal e diretamente correlacionada com a redução de mão-de-obra alocada para a realização da transação, tendo em vista que o cliente passa a realizar cada vez mais autonomamente a transação.

As ferramentas tecnológicas desenvolvidas permitem ampliar o escopo da economia possível para o âmbito do negócio, visualizando-se assim a possibilidade de incrementar o resultado do banco, através da economia com as transações, associada à economia com a infra-estrutura para a realização de negócios.

Talvez resida aqui o argumento econômico-financeiro mais sedutor para o desenvolvimento do Banco Virtual. Quando se simula o custo de operação do Banco Virtual considerando-se o aumento de clientes atendidos pela mesma infra-estrutura, 
observa-se que o mesmo tem a possibilidade de experimentar uma significativa economia de escala.

\subsubsection{Valores Tecnológicos}

Ao examinar o potencial da tecnologia no ambiente bancário, Carmoy (1992), sugere repensar o papel da agência convencional no processo de distribuição, tendo em vista a perspectiva do banque à domicile.

A superação do desafio proposto de integração de plataformas de naturezas transacional e negocial credenciam a instituição a condensar numa única plataforma a operação do banco.

Essa consolidação representa uma poderosa vantagem para a organização cuja conseqüência é dotar o banco de uma solução unificada que funciona em um terminal e, que no limite, pode se configurar como uma plataforma móvel, ou seja, o "banco móvel".

Nessas circunstâncias o Banco Virtual se presta à função de laboratório para desenvolvimento de novas sistemáticas que, uma vez consolidadas, passam a se incorporar ao leque de ofertas da agência tradicional.

O processo de monitoramento das ligações permite um registro contínuo e fidedigno da qualidade do serviço disponibilizado, além de oferecer à organização uma rápida detecção de necessidades de treinamento e correção de posturas e 
comportamentos, identificando principais questionamentos e oportunidades de desenvolvimento de negócios.

\subsubsection{Oportunidades - Especialização e Benefícios}

$\mathrm{Na}$ medida em que se aborda um maior número de segmentos ocorre um incremento de custos referente à necessária estruturação do negócio para se alcançar uma interação bem sucedida. Espera-se, como contrapartida do investimento realizado, um aumento no volume de receitas que deriva do maior nível de especialização para se atingir o mercado.

O desejo de se aumentar o número de segmentos abordados pelas organizações sempre encontrou barreira para o seu desenvolvimento na relação custo benefício, conforme apresentado na Figura 7 - Revendo a segmentação.

Figura 7 - Revendo a segmentação

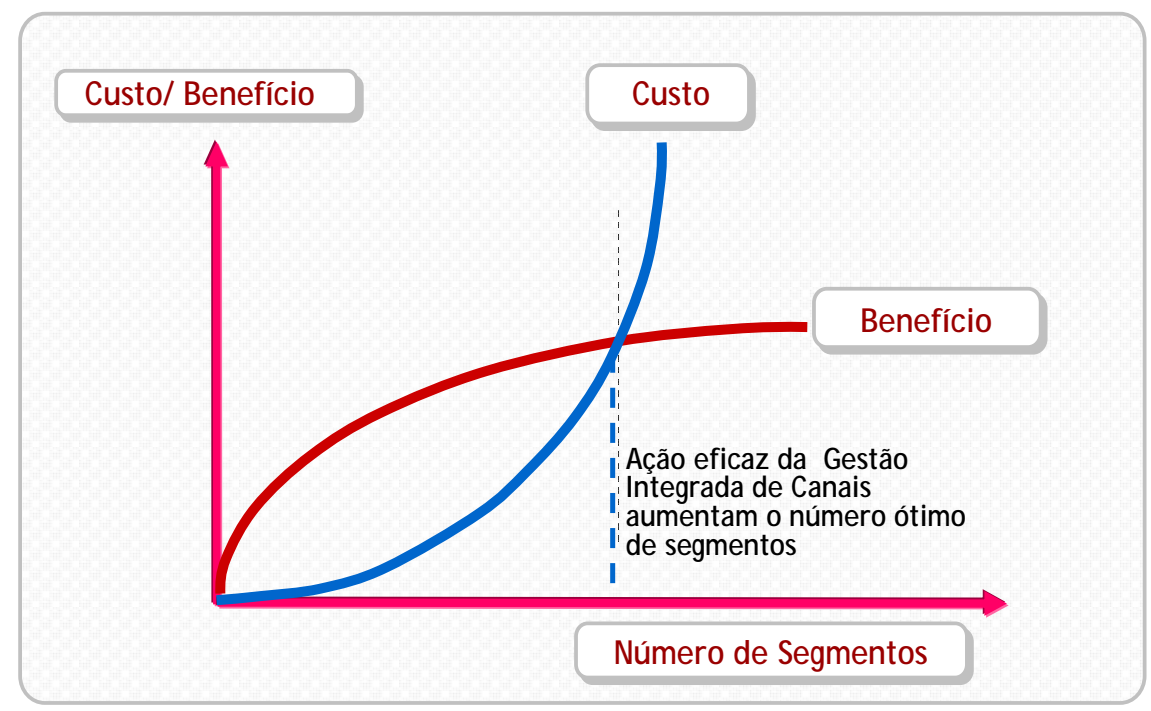

Fonte: Adaptado de The IT Journal - HP 
A quantidade ótima de segmentos a serem abordados pela empresa se dá no encontro das curvas de custo e benefício associados ao número de segmentos tratados.

Entretanto, a aplicação eficaz da Gestão Integrada de Canais proporciona o deslocamento para a direita na condição de equilíbrio, viabilizando um maior número de segmentos a serem abordados com eficácia econômico-financeira e mercadológica.

Conjugando-se o poder de segmentação conferido pelo modelo de abordagem de mercado da indústria de cartão de crédito, com a flexibilidade e modularização disponibilizadas pela gestão do relacionamento e o potencial de distribuição virtual de serviços bancários atinge-se um patamar de posicionamento mercadológico fortemente competitivo e inovador que se caracteriza como uma segmentação lógica, revisitando o modelo convencional de segmentação física.

Ao complementar o mix de distribuição bancária, o Banco Virtual deve buscar continuamente a superação do obstáculo que é a falta do contato físico, como agente de grande valia e incentivo na realização de negócios.

Aliada à dificuldade anteriormente citada há que se considerar a rejeição do cliente ao uso de tecnologia, como também a administração da preferência do cliente pelo contato, ainda que telefônico, com um gerente. 
A conseqüência do custo reduzido na operação do Banco Virtual é a de dotar o banco de uma poderosa e sustentável vantagem competitiva de custos, constituindo-se numa valiosa arma estratégica para a organização.

A consolidação da citada tendência representará uma natural reconfiguração do canal convencional que passará a dispor de mais tempo e recursos para desenvolvimento de sua insuperável capacitação que é a de realização de negócios, mas deixará progressivamente de contar com a presença física dos clientes com os quais se busca a realização de negócios, uma vez que o fluxo de clientes no canal convencional tenderá a ser reduzido.

O movimento migratório de transações conjuga a motivação de redução de custos do banco com o de conveniência por parte do cliente, entretanto essa premissa que é válida no ambiente transacional não é imediatamente extensiva ao cenário negocial.

O Banco Virtual se posiciona como canal de distribuição complementar, flexível e inovativo visando prover o diferencial necessário para atrair, fidelizar e desenvolver relacionamento comercial com o cliente oriundo do canal convencional ou aquele que irá experimentar em caráter inicial a solução no canal alternativo.

\subsection{Segurança}

Seguindo a estratégia de distribuição bancária no conceito de canais remotos preferenciais, os aspectos de segurança são primordiais para que os clientes estabeleçam o necessário vínculo de confiança para a utilização dos canais. 
Em fevereiro de 2007 no Panamá, foi apresentada no Congresso Latino Americano de Segurança da Informação, pesquisa realizada pela empresa Unisys (2007), sobre roubo de dados, realizada em oito países: Austrália, Brasil, França, Alemanha, Hong Kong, México, Reino Unido e Estados Unidos, cuja amostra envolveu 8.500 pessoas entre 18 e 65 anos. No congresso, foram apresentados os principais resultados da pesquisa, evidenciando-se as seguintes tendências:

- 37 \% das reclamações, na Comissão Federal do Comércio dos EUA, foram relacionadas a roubo de identidade, que são todos os tipos de delitos nos quais o indivíduo obtém e utiliza ilicitamente os dados de outra pessoa;

- Entre 100 entrevistados, 10 foram vítimas de roubo de identidade sendo que, os EUA lideram este item com 17 ocorrências;

- 33\% dos clientes recebem informação sobre segurança sendo que 85\% gostariam de receber esta informação;

- $12 \%$ dos entrevistados estão mudando de Instituição Financeira em função da falta de segurança;

- A Biometria foi apontada como o método mais eficaz para evitar o roubo de identidade.

Em recente divulgação do Federal Financial Institutions Examination Council, houve recomendação de que toda instituição financeira deverá utilizar no mínimo dois fatores de autenticação para se relacionar com os Clientes, remotamente, a partir de 2007.

Os fatores de autenticação classificam-se em três vetores: 
1) O que você sabe: senha, frases, etc;

2) O que você tem: Cartão, Smartcard, Token ou TanCode;

3) O que você é: Características Biométricas.

Todos esses fatores conjugados determinam a dinâmica de relacionamento seguro entre cliente $x$ banco, possibilitando que as transações sejam realizadas com conveniência e facilidade de uso em cada um dos canais de relacionamento preferenciais remotos. Porém, essa dinâmica deverá ser alinhada a toda uma cultura de utilização e comunicação gradual, a ser implementada pelos bancos por meio de ações integradas de marketing.

\subsection{Marketing de Relacionamento}

\subsubsection{Conceito}

Para Gordon (1999) O Marketing de Relacionamento é: "o processo continuo de identificação e criação de novos valores com clientes individuais e o compartilhamento de seus benefícios durante uma vida toda de parceria" Ou seja, uma condição que a empresa deve seguir para que ela saiba o que o cliente quer, criando um entendimento na mente do cliente do que ela pode lhe oferecer, ou seja, os benefícios.

Segundo Gordon (1999), o marketing de relacionamento se concentra nos processos e no que for necessário para aprimorar o relacionamento com o cliente, não apenas nos envolvimentos de linha de frente com ele. Ele procura transformar a empresa em uma outra que seja mais hábil em administração como uma empresa 
digital, na qual as tradicionais "leis" de marketing sejam ultrapassadas. No mundo digital, os clientes são importantes individualmente e, assim, atendidos com produtos personalizados e customizados em massa, processos de serviços e de comunicações.

Segundo Kotler e Armstrong, (2003), Marketing de Relacionamento, significa "criar, manter e aprimorar fortes relacionamentos com os clientes e outros interessados. Além de elaborar estratégias para atrair novos clientes e criar transações com eles, as empresas empenham-se em reter os clientes existentes e construir com eles relacionamentos lucrativos e duradouros. O marketing é visto agora como a ciência e a arte de descobrir, reter, cultivar clientes lucrativos".

Segundo os autores (op.cit.) "a chave para a construção de relacionamentos duradouros é a criação de valor e satisfação superiores para o cliente. Clientes satisfeitos têm maior probabilidade de se tornar clientes fiéis, e clientes fiéis têm maior probabilidade de dar à empresa uma participação maior em sua preferência. Atrair e reter clientes pode ser uma tarefa difícil". Atualmente os clientes têm à sua disposição uma grande variedade de escolha de produtos e marcas, preços e fornecedores. A empresa deve responder a uma pergunta-chave: como os clientes escolhem? A resposta é que eles escolhem a oferta de marketing que acham que irá Ihes entregar maior valor. Ficam satisfeitos e continuam a comprar ofertas que satisfazem ou ultrapassam suas expectativas de valor. 
A Figura 8 - Marketing de Relacionamento passado e futuro compara as principais diferenças do marketing tradicional, em relação às novas necessidades e expectativas dos clientes, que os auxilia na decisão de compra de um produto:

\subsubsection{Passado e Futuro}

Figura 8 - Marketing de Relacionamento passado e futuro

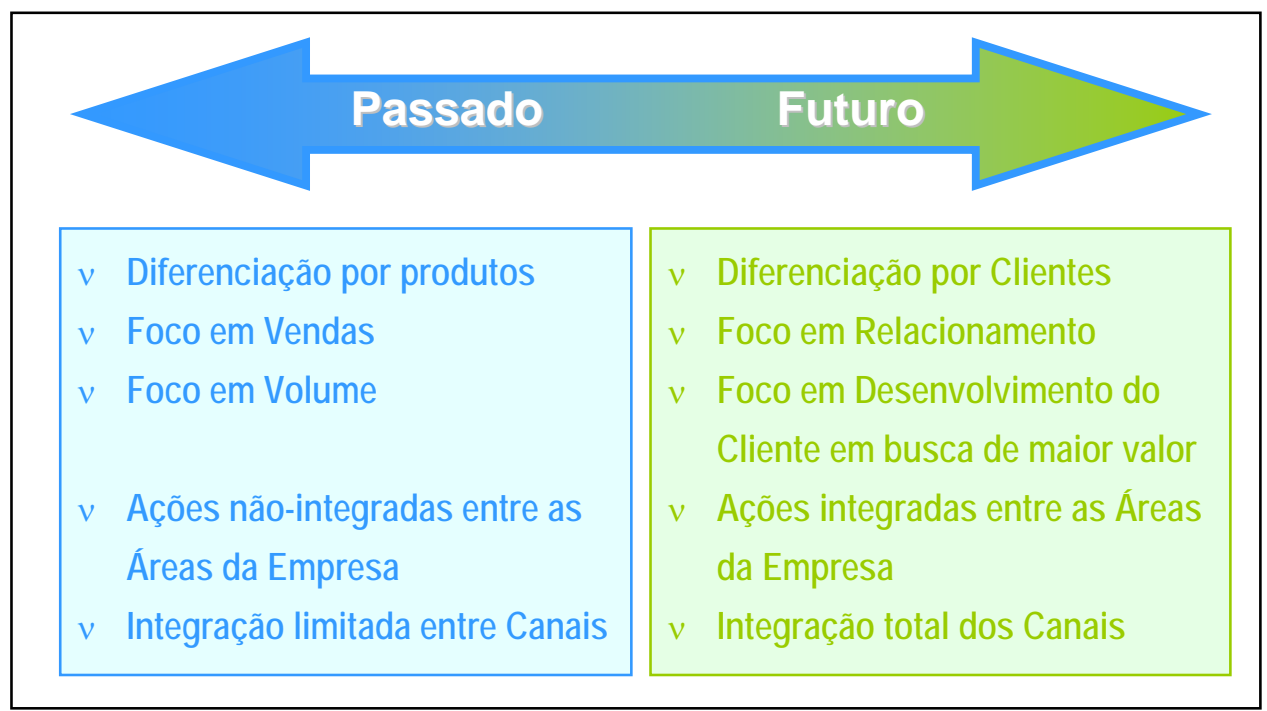

Fonte: Adaptado de Ian Gordon(1999).

Para Gordon (1999), as empresas dos dias atuais se concentram em seis atividades: tecnologia e clientes individuais, objetivos da empresa, seleção e rejeição de clientes, uma cadeia de relacionamentos, reavaliação dos quatro "Ps" do marketing (produto, preço, promoção e ponto de distribuição) e utilização de gerentes de relacionamento para ajudar as empresas a criarem novos valores com outras.

A conseqüência natural do foco na especialização no cliente combinado com a introdução do conceito de virtualidade no processo de distribuição é demonstrada no Quadro 1 - Revendo o Marketing Mix, com a sugerida revisão do "Marketing Mix", 
onde nessa condição, passa a imperar o Marketing de Relacionamento, como veículo direcionador das ações de natureza mercadológica.

Quadro 1 - Revendo o Marketing Mix

\begin{tabular}{|c|c|}
\hline $\begin{array}{l}\text { Conceito tradicional dos } 4 \text { P’s } \\
\text { não funciona mais } \\
\text { - Produtos: transformaram-se em } \\
\text { commodities, necessitam de } \\
\text { outras formas para se diferenciar. } \\
\text { - Ponto de distribuição: } \\
\text { revendedores são proprietários do } \\
\text { relacionamento com o cliente } \\
\text { - Preço: necessitam de outra } \\
\text { maneira para um prêmio no preço } \\
\text { - Promoção: marketing de massa } \\
\text { está perdendo eficiência } \\
\text { (propaganda) }\end{array}$ & $\begin{array}{l}\text { Os novos } 5 \text { C's do marketing de } \\
\text { relacionamento } \\
\text { - Cliente: produtos e serviços } \\
\text { projetados para atender } \\
\text { necessidades específicas } \\
\text { - Custo: custo de satisfazer o } \\
\text { cliente versus preço do produto } \\
\text { - Conveniência para o cliente: } \\
\text { onde, quando e como quiser } \\
\text { comprar; o ponto de distribuição } \\
\text { pode ser virtual } \\
\text { - Comunicação: dois sentidos, } \\
\text { diálogo sob medida com o cliente } \\
\text { - Cuidado com o cliente: } \\
\text { resultando em rentabilidade } \\
\text { crescente }\end{array}$ \\
\hline
\end{tabular}

Fonte: Adaptado de The IT-Journal - HP

\subsubsection{Marketing one-to-one}

Segundo Peppers and Rogers (2000), "para que uma empresa possa utilizarse do conceito de marketing one-to-one, ela precisa voltar a fazer negócios como nos tempos de nossos avós":

Os autores (op.cit) mencionam que "Fizemos negócios por milhares de anos até que a tecnologia nos permitiu produzir bens e serviços em massa, para mercados de massa. De um dia para o outro, esquecemos como praticar o one-toone. Em vez de vender para clientes de forma individual, passamos a lutar por maior participação de mercado. Em vez de falar com os clientes de forma individual para conhecer suas necessidades, começamos a realizar pesquisas de mercado, 
segmentações, modelos estatísticos que permitissem predizer tendências e padrões de compra".

Para Peppers e Rogers (2000), não há dúvidas de que a produção em massa trouxe riqueza e prosperidade em várias regiões do mundo, mas que também, houve conseqüências, pois a competição global criou naturalmente uma guerra mundial de "descontos", o que pode beneficiar algumas empresas em curto prazo, mas que reduz a lucratividade com o passar do tempo.

Figura 9 - Migração para one-to-one representa como pode ser viabilizado o processo de mudança de estratégia das empresas para atuação no modelo de marketing one-to-one:

Figura 9 - Migração para one-to-one

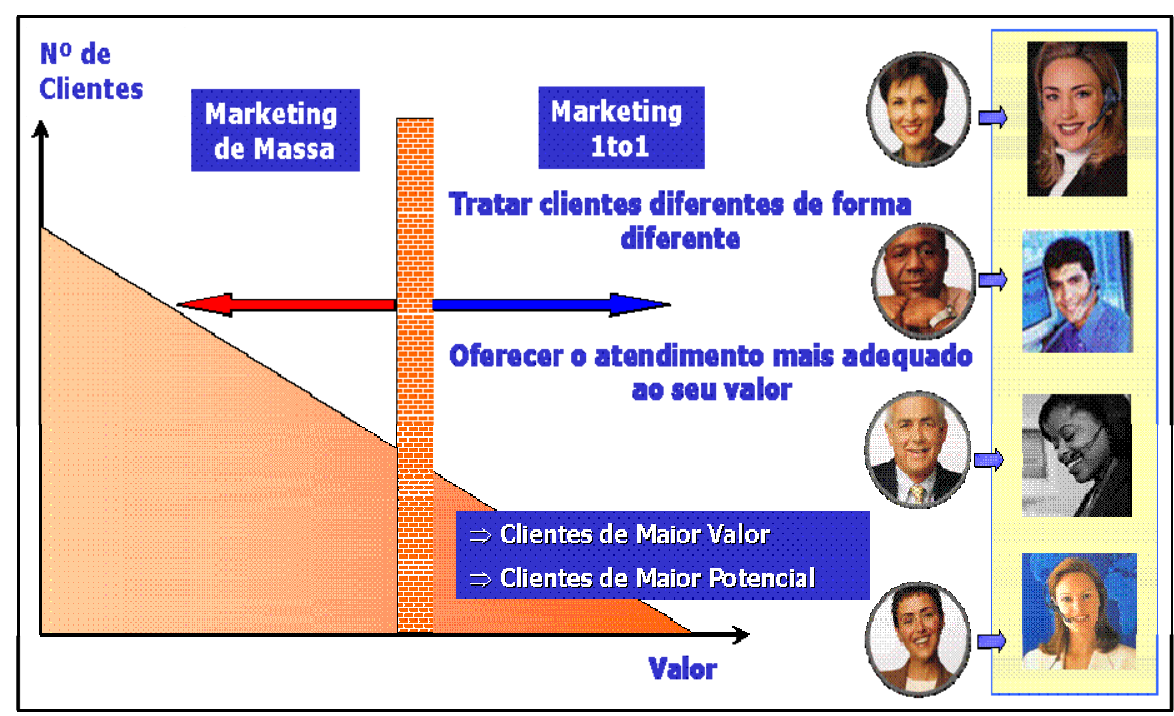

Fonte: Adaptado de CRM Series Marketing one-to-one 


\subsubsection{Segmentação física e lógica}

Pela ótica de consumidores, será que realmente estamos satisfeitos com as ofertas e os produtos disponíveis nos mais variados meios de distribuição em massa, ou mesmo, comparando as empresas que se dispõem a ofertar produtos ditos diferenciados ou especializados? Será que nossa satisfação como consumidores está sendo plenamente atendida?

Novos conceitos estão surgindo e inúmeros paradigmas estão sendo quebrados, onde o grande divisor de águas entre o potencial de distribuição de produtos em massa, porém, em nichos e públicos específicos, sem dúvida, está sendo ocasionado pela tecnologia e o grandioso potencial de comunicação que a Internet possibilita.

Para se estabelecer um paralelo, Anderson (2006) cita que "antes da Revolução Industrial, quase todas as culturas eram locais. A economia era agrária, o que distribuía as populações com tanta dispersão quanto as terras disponíveis, e a distância dividia as pessoas. A cultura era fragmentada, gerando sotaques regionais e músicas folclóricas. A falta de meios de comunicação e de transportes rápidos limitava a miscigenação cultural e a propagação de novas idéias e tendências. Essa foi a primeira era da cultura de nicho, determinada mais pela geografia do que pela afinidade".

O autor (op.cit) cita que "uma maneira de raciocinar sobre as diferenças entre as escolhas limitadas de ontem e a abundância de hoje é comparar nossa cultura com um oceano em que só aflorassem na superfície as ilhas de sucesso. Nele se 
avistam uma ilha de músicas feitas apenas das mais ouvidas nas paradas de sucesso, uma ilha composta somente de campeões de bilheteria, um arquipélago de programas populares de TV do horário nobre e assim por diante. Imagine a linha de flutuação como sendo o limiar econômico da categoria, o volume de vendas necessário para satisfazer os canais de distribuição com capacidade escassa, ou seja, o espaço de prateleira da maioria dos grandes varejistas. Perscrute o horizonte cultural e o que se destaca são os picos da popularidade elevando-se acima das ondas. No entanto, as ilhas são, na verdade, apenas os cumes de grandes montanhas subterrâneas".

Anderson (2006) declara ainda que "Quando o custo de distribuição cai, é como se o nível da água baixasse no oceano. De repente, despontam na superfície áreas até então submersas. E o que está abaixo da linha d'água é muito maior do que à tona. Agora, à medida que os varejistas on-line exploram suas extraordinárias eficiências econômicas, começamos a divisar as encostas de grandes montanhas de escolhas, onde antes, se avistava apenas o pico".

Para demonstrar essa constatação frente à economia atual na era digital, Anderson (2006) concentrou-se em alguns segmentos de mercado analisando em especial, a indústria do entretenimento, concluindo que para os produtos, cuja oferta pode se tornar ilimitada diante de potencial da Internet, que os antigos pressupostos sobre o papel dos grandes hits e dos nichos estavam absolutamente errados.

O autor (op.cit) conclui que "A escassez exige grandes sucessos - se existe pouco espaço nas prateleiras ou nas ondas de broadcast, o único procedimento 
sensato é enchê-las com os títulos que venderão mais. E se essa for a única oferta, só se comprará isso".

A pesquisa de Anderson (2006), que envolveu os principais líderes da nova indústria do entretenimento digital desde Amazon até a iTunes, deu origem a um novo conceito, denominado de "A Cauda Longa", efeito que estaria por meio da tecnologia, convertendo o mercado de massa em milhões de nichos.

Para exemplificar esse efeito, Anderson realizou um estudo com o Rhapsody, empresa que atua no mercado de venda de músicas on-line, por meio do serviço de assinatura (streaming mídia), de propriedade da Real Networks, tendo atualmente disponíveis em tempo real para seus assinantes, mais de 1,5 milhão de faixas musicais

Anderson (2006) cita que "Quando se lançam num gráfico as estatísticas mensais da Rhapsody, obtém-se uma curva de demanda parecida com a de qualquer loja: enorme procura pelas faixas principais, que despenca abruptamente e se estende numa cauda cada vez mais baixa, abrangendo músicas menos populares".

Abaixo na Figura 10- Desempenho nas vendas de músicas Rhapsody, encontra-se um gráfico que representa as 25 mil faixas mais vendidas pela Rhapsody em dezembro de 2005. 
Figura 10- Desempenho nas vendas de músicas Rhapsody



Fonte: Anderson, Chris. A Cauda Longa: Do mercado de massa para o mercado de nicho.

Anderson (2006) esclarece que "Os esforços estão concentrados em um pequeno número de faixas no lado esquerdo do gráfico, junto ao eixo vertical, o que em uma loja de CDs com limitação de espaço físico nas prateleiras representaria as faixas de grande sucesso, sendo natural a definição de um corte não muito longe do pico. Essa é a definição comparativa com o estoque do Wal-Mart, o maior varejista de músicas dos Estados Unidos, cujos 4.500 principais álbuns abrangem cerca de 25.000 faixas, onde os 200 principais álbuns correspondem por cerca de $90 \%$ das vendas".

O autor (op.cit) menciona que "Essa era a visão do mercado no século passado, com limitações físicas que definiam algum ponto de corte em seus estoques, mantendo uma cultura movida a sucessos. Porém, na nova cultura da era digital, a limitação física praticamente não existe, trazendo uma nova dinâmica de mercado". 
Anderson (2006) dá seqüência à análise gráfica e menciona que "continuando a análise do desempenho de vendas da Rhapsody, se olhamos para o lado direito do gráfico, iremos perceber que as faixas consideradas não hits possuem vendas pequenas, porém, devido à inúmera oferta de títulos, a somatória das vendas dessas faixas, corresponde por um quarto do negócio total da Rhapsody".

Figura 11- Desempenho nas vendas de músicas Rhapsody

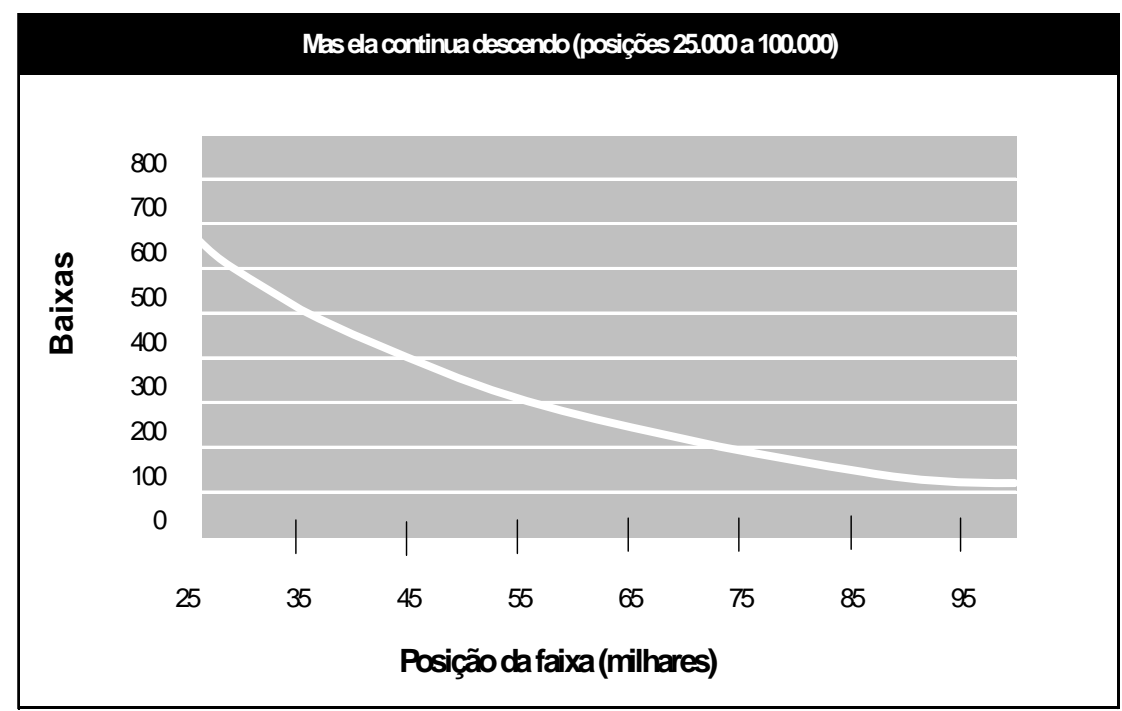

Fonte: Anderson, Chris. A Cauda Longa: Do mercado de massa para o mercado de nicho.

Na Figura 11- Desempenho nas vendas de músicas Rhapsody, se comparada ao gráfico anterior, havia indícios e de que em um dado momento, os volumes de vendas pudessem chegar a zero, porém, percebemos que mesmo chegando mais próximo da extremidade final da cauda, ainda ocorrem muitas vendas.

Segundo Anderson (2006) "O mais extraordinário é que se venderá praticamente cada uma dessas faixas. Sob a perspectiva de lojas como o Wal-Mart, a indústria de música se limita a menos de 60.000 faixas. Contudo, para varejistas on-line, como o Rhapsody, o mercado é aparentemente infinito. Sempre há alguém 
que baixa, pelo menos uma vez por mês, não só alguma de suas 60.000 faixas mais vendidas, mas também outras de suas 100 mil, 200 mil ou 400 mil faixas principais e até suas 600 mil, 900 mil faixa mais importantes, e ainda mais do que isso. $E$ assim se forma a Cauda Longa".

Anderson (2006), afirma ainda que "o novo mercado de nichos não está substituindo o tradicional mercado de hits, apenas, pela primeira vez, os dois estão dividindo o palco. Durante um século, fomos muitos seletivos em nossas triagens e só deixávamos passar o que tinha condições de se transformar em campeão de venda, para utilizar da maneira mais eficiente possível as dispendiosas prateleiras, telas, canais e atenção. Agora, numa nova era de consumidores em rede na qual tudo é digital, a economia da distribuição está mudando de forma radical, à medida que a Internet absorve quase tudo, transmutando-se em loja, teatro, difusora, por uma fração mínima do custo tradicional".

Anderson (2006), conclui que "esses novos negócios com espaço infinito nas prateleiras efetivamente aprenderam as lições da nova matemática: um número muitíssimo grande (os produtos que se situam na Cauda Longa) multiplicado por um número relativamente pequeno (os volumes de vendas de cada um) ainda é igual a um número muito grande. E, ainda mais uma vez, esse número muitíssimo grande está ficando cada vez maior".

Se transpusermos essa mesma lógica para o cenário de distribuição bancária, teremos inúmeras oportunidades de aplicabilidade, principalmente para os grandes bancos de varejo. 
A Figura 12 - Segmentação Física e Lógica, representa em sua grande maioria, a dinâmica atual de segmentação dos clientes praticada pelos bancos.

Figura 12 - Segmentação Física e Lógica

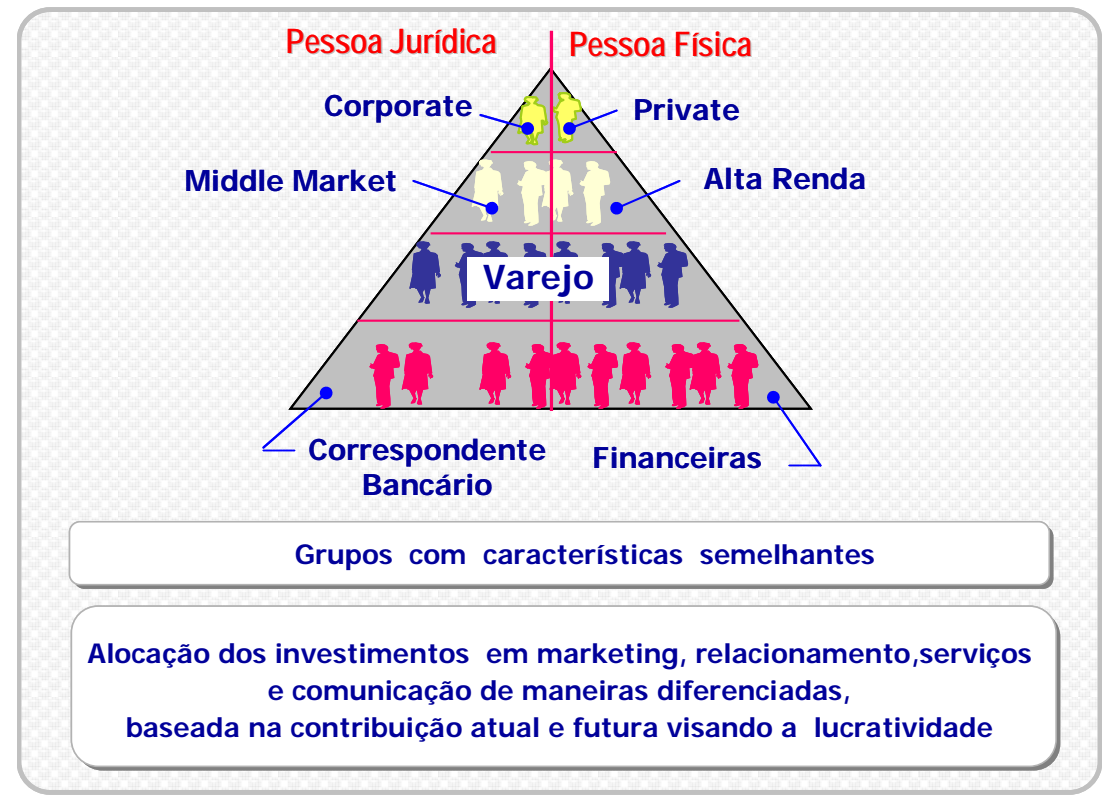

Fonte: Adaptado de Estrutura de Segmentação Banco Bradesco S.A.

Quando se avaliam os segmentos representados na Figura 12, somente pela perspectiva física, encontram-se inúmeras barreiras no que tange à préidentificação, ofertas de produtos e serviços customizados, principalmente quando se concentra na base da pirâmide, pois, à analogia do que ocorre com Cris Anderson, pode-se afirmar que no topo da pirâmide, os segmentos de pessoas físicas e jurídicas - Corporate, Private, Middle Marketing e Alta Renda - podem ser considerados como os grandes "Hits" e invariavelmente terão toda a atenção e certamente serão os principais geradores de receita para os bancos, justificando-se o investimento para que sejam tratados de forma diferenciada e customizada mesmo no mundo físico. 
Porém, nos bancos de varejo, a base da pirâmide possui uma importância extremamente relevante e estratégica, uma vez que o potencial da nova economia digital, incrementado pelo tráfego de voz, dados e imagem, permitirá uma visão ímpar de todos os clientes da base da pirâmide, devendo no futuro, possibilitar novas fragmentações de modo a representar uma infinidade de novos segmentos e nichos específicos, dentro da grande massa do público de varejo. Exprimindo e maximizando em sua essência, a segmentação lógica.

\subsection{5 $\underline{\text { CRM - Conceito }}$}

Inúmeras são as definições sobre o que é CRM e suas aplicabilidades. Conceitualmente, será importante abordar algumas das visões que os principais especialistas sobre o assunto defendem.

De acordo com Peppers and Rogers Group (2004), "a chamada Era do Marketing de Massa está agora dando lugar a uma nova época que poderia se denominar de (Era da Interatividade) ou (Era da Gerência do Relacionamento com Clientes)".

Os autores afirmam que "Essa era a forma como os comerciantes se relacionavam com os clientes no passado, quando havia poucos clientes e conheciam-se suas necessidades, preferências, poder aquisitivo e outras características que permitiam um relacionamento tão personalizado que era impossível à concorrência oferecer um serviço semelhante". 
Segundo Greenberg (2001), CRM pode ser definido como "uma estratégia disciplinada de negócios, voltada a criar e sustentar relações lucrativas de longo prazo com os clientes. As iniciativas bem-sucedidas de CRM começam com uma estratégia e filosofia de negócios que alinhem as atividades da empresa em torno das necessidades dos clientes. A tecnologia CRM é um capacitador crítico dos processos necessários para transformar estratégias em resultados".

Já o Gartner Group (2000), define CRM como “uma estratégia de negócio voltada ao entendimento e à antecipação das necessidades dos clientes atuais e potenciais de uma empresa".

Para Peppers and Rogers (2000), CRM Customer Relationship Management, significa "estabelecer relacionamento com os clientes de forma individual e depois usar as informações coletadas para tratar clientes diferentes de maneira diferente. $\mathrm{O}$ intercâmbio entre um cliente e a empresa torna-se mutuamente benéfico, uma vez que os clientes oferecem informações em retribuição aos serviços personalizados que atendem às suas necessidades individuais".

Segundo Cláudia Domenici - Ernest \& Young Consulting (2001), “CRM é uma estratégia de negócios com foco na otimização de receita, visando gerenciar a rentabilidade dos relacionamentos de uma empresa com sua base de clientes".

Para Stanley Brown (2001), “CRM é uma estratégia de negócios que visa entender, antecipar e administrar as necessidades dos clientes atuais e potenciais de uma organização. É uma jornada de estratégias, processos, mudanças 
organizacionais e técnicas pelas quais a empresa deseja administrar melhor seu próprio empreendimento acerca do comportamento dos clientes".

Para Miriam Bretzke (2000), Customer Relationship Management ou Gerenciamento do Relacionamento, como o próprio nome indica "é a integração entre o Marketing e a tecnologia da Informação para prover a empresa de meios mais eficazes e integrados para atender, reconhecer e cuidar do cliente, em tempo real e transformar estes dados em informações que disseminadas pela organização permitem que o cliente seja "conhecido" e cuidado por todos. Desta forma, um dos fatores mais importantes para o sucesso são os recursos humanos, que precisam ser treinados e capacitados, em todos os níveis, não só para melhorar a qualidade do atendimento, mas também para usar adequadamente as informações que transformam possibilidades de negócios em lucros. Essa integração singular pressupõe que a empresa esteja disposta a manter um relacionamento suportado por processos operacionais mais ágeis e selecione a tecnologia adequada, e isto requer metodologia, expertise e experiência comprovada neste tipo de solução. É uma grande virada no conceito de atendimento ao cliente, que extrapola a prática existente em qualidade, e possibilidade de aumentar a fidelidade do cliente e conseqüentemente a rentabilidade".

A Figura 13 - Principais Processos para viabilizar o CRM demonstra os passos básicos envolvendo os macro-processos necessários para a implantação e a manutenção das ações que norteiam o conceito e a aplicabilidade do CRM. 
Figura 13 - Principais Processos para viabilizar o CRM

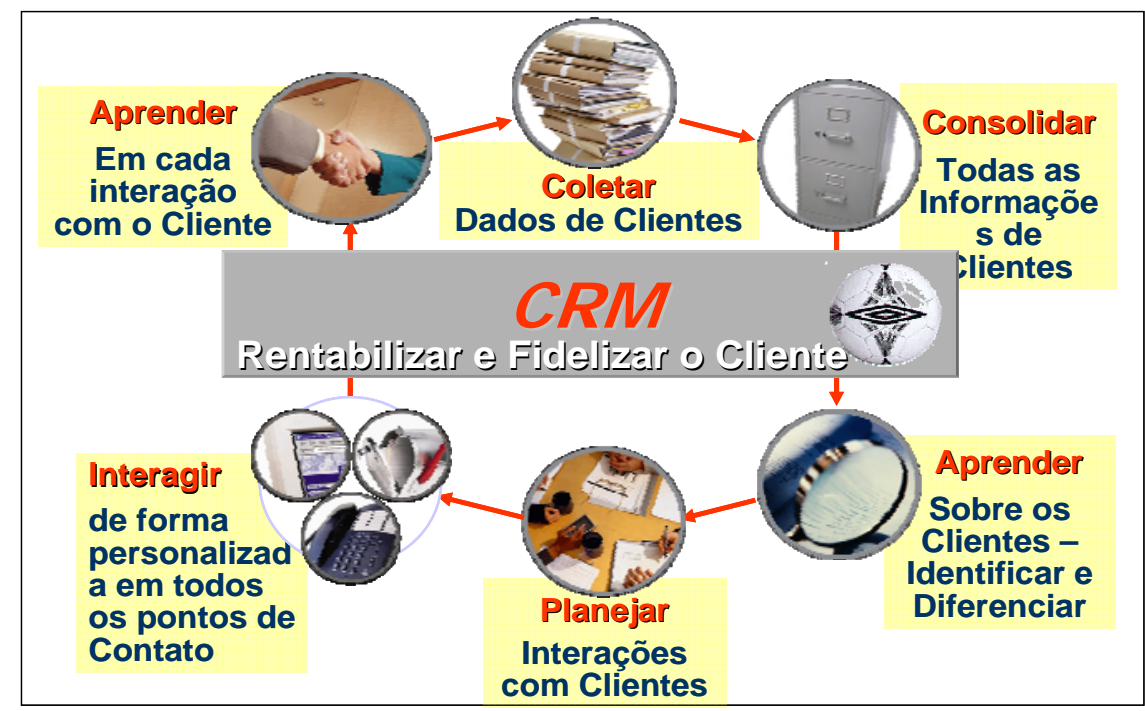

Fonte: Adaptado de Peppers and Rogers Group

Do ponto de vista tecnológico, CRM envolve capturar os dados do cliente ao longo de toda a empresa, consolidar todos os dados capturados interna e externamente em um banco de dados central, analisar os dados consolidados, distribuir os resultados dessa análise aos vários pontos de contato com o cliente e usar essa informação ao interagir com o cliente através de qualquer ponto de contato com a empresa" (Peppers and Rogers Group, 2004).

O presente estudo tem por objetivo, demonstrar sua aplicabilidade, dentro de um conceito de processos estruturados, possibilitando utilizar ao máximo o potencial de convergência entre os atuais canais de relacionamento disponíveis na indústria bancária, aproveitando o diferencial competitivo do fluxo pré-identificado de clientes, de acordo com o perfil de consumo e psicológico dos clientes. 


\subsubsection{CRM - Tecnologia de Relacionamento - Database Marketing}

Segundo Jackson e Wang (1997), "o database marketing é um método de longo prazo, voltado para o cliente e profundamente baseado em informações. O database pode ser utilizado para interligar e orientar os esforços de marketing atuais, assim como para construir uma base completa de informações, de modo a orientar futuros projetos". O database marketing sempre inclui:

- Um conjunto abrangente de dados inter-relacionados, que atende a diversas aplicações e permite a recuperação de informações precisas e oportunas.

Esse tipo de marketing interliga as informações relacionadas ao cliente, como transações de compra, produtos adquiridos, promoções, mídia, dados geodemográficos, estilo de vida, dados demográficos e características financeiras.

Para Jackson e Wang (1997), a definição clássica de database marketing é a de "um método que avalia individualmente cada tática ou contato de marketing. Já o database marketing moderno, usa o database como alicerce para os projetos de marketing em andamento".

O conceito do database marketing representa um avanço significativo na capacidade das empresas direcionarem seus esforços visando satisfação dos seus clientes na individualidade.

Essa prerrogativa é extremamente poderosa na medida em que promove o desenvolvimento de ferramentas de fidelização com probabilidade ampliada de êxito 
e acaba por dotar as empresas de um mecanismo de diferenciação competitiva capaz de posicioná-las com destaque em seu mercado de atuação e, eventualmente, em outros, nos quais uma abordagem convencional de segmentação não se justifique economicamente.

Quando se considera a hipótese de se analisar e conhecer os clientes como indivíduos únicos, o conceito de tradicional de segmentação, a partir do qual se aglutinam grupos com interesses comuns visando-se sustentar uma estratégia de abordagem de mercado, passa a ser uma solução subotimizante de atendimento das necessidades dos clientes, sendo o database marketing o responsável pela nova solução potencial.

Conforme descreve Negroponte (1995), “Na era da pós-informação, o público que se tem é, com freqüência, composto de uma única pessoa. Tudo é feito por encomenda, e a informação é extremamente personalizada".

Prossegue o autor afirmando que "parte-se de um grupo grande para um grupo pequeno; depois, para um grupo menor ainda; por fim, chega-se ao indivíduo. Quando você tiver meu endereço, meu estado civil minha idade, minha renda, a marca do meu carro, a lista de compras que faço, o que costumo beber e quanto pago de imposto, você terá a mim: uma unidade demográfica composta de uma só pessoa".

Uma das formas de tratamento dos registros que formam o database marketing, para que dele se possa extrair subsídios para gestão é o método da RFV 
- Recência, Freqüência e Valor, apresentado por Hughes (1998), como sendo "um método de dividir em categorias os registros presentes em um banco de dados, de forma a podermos conhecer quem são os compradores mais recentes, os que compram com mais freqüência e quem são os que mais gastam com nossos produtos. É um modo de definir perfis por comportamento".

É importante observar que o database marketing não se restringe apenas ao apoio de uma abordagem individualizada de clientes. Quando se detêm um banco de dados com essas características, pode-se freqüentemente realizar-se levantamentos sobre agregados cujo resultado permite avaliar o desempenho de diversos setores econômicos, hábitos regionais, comportamentos sazonais, entre outras considerações, amparando-se, por exemplo, análises e decisões de investimento, aumentando-se assim o escopo do uso da ferramenta.

O potencial de contribuição para a gestão competitiva conferida pelo database marketing é conseqüência direta do estágio atual de evolução da tecnologia da informação, definida por Cruz (1997), como sendo "o conjunto de dispositivos individuais, como hardware, software, telecomunicações ou qualquer outra tecnologia que, faça parte ou gere tratamento da informação, ou ainda, que a contenha".

A consolidação do uso do database marketing, enquanto ferramenta que propicia uma visão mais focada na individualidade do cliente, é de crucial importância para a revisão das premissas que alicerçam a gestão de negócios, impulsionando a evolução dos mesmos da "Era da Manufatura" para a "Era do 
Serviço" até alcançar a "Era do Cliente", conforme apresentado no Quadro 2 Revendo as Premissas Fundamentais do Negócio.

Quadro 2 - Revendo as Premissas Fundamentais do Negócio

\begin{tabular}{|c|c|c|c|}
\hline & Era da Manufatura & Era do Serviço & Era do Cliente \\
\hline Marketing & Subjetivo & Início de Análise & $\begin{array}{c}\text { Necessidade de } \\
\text { maior entendimento } \\
\text { do cliente }\end{array}$ \\
\hline $\begin{array}{l}\text { Valor do } \\
\text { Cliente }\end{array}$ & $\begin{array}{c}\text { Clientes igualmente } \\
\text { valorizados }\end{array}$ & $\begin{array}{l}\text { Alguns clientes têm } \\
\text { maior valor do que } \\
\text { outros }\end{array}$ & $\begin{array}{l}\text { Quase todo cliente } \\
\text { pode ser uma fonte } \\
\text { de lucro }\end{array}$ \\
\hline $\begin{array}{l}\text { Foco no } \\
\text { Cliente }\end{array}$ & $\begin{array}{c}\text { Contato pessoal é } \\
\text { vital }\end{array}$ & Consistência é vital & $\begin{array}{c}\text { Informações } \\
\text { completas são vitais }\end{array}$ \\
\hline Customização & Customização é Cara & $\begin{array}{c}\text { Customização é } \\
\text { Cara }\end{array}$ & $\begin{array}{c}\text { Serviço } \\
\text { customizado é } \\
\text { essencial }\end{array}$ \\
\hline
\end{tabular}

Fonte: Adaptado de The IT-Journal-HP

No Quadro 2, pode-se observar o nível crescente da preocupação com a satisfação das necessidades específicas com o cliente, quando se alcança a "Era do Cliente". Sem uma estrutura de informações e o adequado tratamento das mesmas, essa premissa não se viabilizaria tendo em vista que a especialização desejada atinge o status de unidade.

\subsubsection{Mudanças de Cenários face às Múltiplas Tecnologias}

As mudanças nos cenários mercadológicos têm se tornado cada vez mais rápidas e impactadas pela evolução das múltiplas tecnologias disponíveis que ao permitirem o declínio dos custos de hardware e telecomunicações, aumentam o número de Internautas no Brasil, assimilando rapidamente a cultura de utilização das múltiplas facilidades que a convergência das tecnologias de infra-estrutura, voz, 
dados, vídeo e computação, influenciando fortemente seu ambiente de consumo e entretenimento, cultura, regras de convívio e suas estruturas sociais.

A equação que envolve todos esses componentes disponibiliza aos consumidores uma enorme variedade de produtos e serviços que pelas suas características de nascimento em uma cultura digital, possuem menores custos, com maiores funcionalidades, simplicidade e principalmente, total mobilidade e conveniência.

Segundo Davis e Meyer (1999), a infra-estrutura digital construída ao longo das últimas três décadas, tornou realidade a conexão entre pessoas, máquinas, organizações, combinados de todas as maneiras possíveis a qualquer tempo, em qualquer lugar.

O Brasil é o quinto maior mercado de celulares no mundo, tendo no início de 2007, alcançado o marco histórico de 100 milhões de aparelhos celulares móveis e mais de 50 milhões de telefones fixos, demonstrando-se que o potencial de utilização das novas tecnologias se torna cada vez mais rapidamente acessível aos mais variados públicos.

Em reportagem da Revista Veja (2006), é demonstrada essa força tecnológica que impulsiona os projetos de mobilidade no mundo. Segundo a publicação, "o celular está entre os eletrônicos que conquistaram de forma mais rápida consumidores em todo o planeta. O aparelho chegou à marca de 50 milhões de usuários em cinco anos. A televisão demorou treze anos para atingir público 
semelhante e o rádio, 38 anos. Hoje existem 2,5 bilhões de celulares no mundo - 0 equivalente a 38\% da população global. No mercado nacional, $80 \%$ do total de aparelhos celulares são pré-pagos sendo que a média mundial é de $60 \%$. A previsão é que em 2010, serão 4 bilhões de aparelhos celulares em todo o Planeta".

Nesse contexto, ao se estabelecer um paralelo com os conceitos de "produção enxuta", descritas por Womack e Jones (1990) no best seller "a máquina que mudou o mundo", no qual os autores fazem referência ao modelo de produção de veículos adotado pelo Japão que revolucionou a indústria de veículos, após longos anos de domínio do modelo de produção em massa desenvolvido por Henry Ford, pode-se afirmar que o celular será sem dúvida, o grande precursor que impulsionará a convergência no século XXI, quando se poderá considerá-lo respeitosamente, como a segunda máquina que mudou o mundo.

\subsubsection{Tecnologias Emergentes no Sistema Financeiro}

Segundo informações divulgadas na CIAB (2003), o "expertise do setor em tecnologia bancária evoluiu muito nos últimos anos, o cartão magnético, os caixas eletrônicos, o banco 24 horas, as transações via telefone e, com a Internet, entraram no ar os portais das instituições financeiras".

O relatório informa ainda que "com os bancos virtuais, a rotina do mercado financeiro mudou radicalmente, seja pelo aumento e difusão de informações, seja pelo aumento de ferramentas colocadas à disposição dos clientes e gestores ou ainda pela facilidade e conveniência surgida com horários estendidos e novos serviços como consultoria on-line, simuladores e, agregadores de contas". 
Segundo informações divulgadas na CIAB (2003), "as transações em tempo real viraram padrão e, com a mobilidade, aumentam as demandas por serviços de maior valor agregado que estão diretamente relacionados com a velocidade na comunicação e acesso remoto aos dados bancários em todos os canais: celulares, computadores, pontos de venda no comércio e terminais eletrônicos de autoatendimento".

Mesmo em países como o Brasil, onde a cultura do cheque tornou-se dominante, meios eletrônicos de pagamento conquistam novos usuários a cada dia e os sinais digitais passam a ser o meio preponderante de circulação da moeda.

A evolução da tecnologia continuará a revolucionar a relação dos bancos com seus clientes e vice-versa, forçando os bancos a aprofundar seu conhecimento sobre os clientes e sobre o mercado, para que possam rever continuamente as necessidades e preferências de seu público, mantendo, dessa maneira, atualizadas propostas de valor capazes de proporcionar uma experiência distintiva, sustentada pela consistência dos serviços eficientemente disponibilizados.

O relatório divulgado na CIAB (2003) conclui que a "visão dos serviços bancários tem de ser associada ao entendimento da tecnologia da informação e canais emergentes, uma vez que tendências já visíveis para clientes de maior potencial de consumo e renda, no futuro estarão disponíveis a toda a população bancarizada". 
Em pesquisa realizada pela Febraban (CIAB 2003) foram identificadas as principais tecnologias emergentes e sua respectiva empregabilidade nos processos de automação bancária, algumas delas em uso atualmente pelos principais entidades financeiras nacionais, ou que estão em estudo para implantação, conforme demonstra a Figura 14 - Tecnologias Emergentes - Processo de Automação Bancária.

Figura 14 - Tecnologias Emergentes - Processo de Automação Bancária

\begin{tabular}{|ll|}
\hline Tecnologia & Automação BanCária \\
\hline - Código de barras & - Pagamentos de contas (banalização do uso) \\
- Multimedia e convergência de mídias & - ATM'S conversacionais, vendas em auto- serviços \\
- Reconhecimento de Imagens & - Processamento de cheques e contas \\
- Inteligência Artificial & - Reconhecimento de assinaturas \\
- Redes Wirelles & - Vendas \\
- Criptografia / Segurança & - Internet Banking \\
- Cartões inteligentes & - Pocket Banking \\
- Telefone Celular + Notebook & - Intercâmbio de informações \\
- CRM & - Conhecimentos do Cliente \\
- Biometria & - Segurança \\
- Certificação Digital (e-CPF e e-CNPJ) & - Segurança e documentação \\
- GED (Gerenciamento Eletrônico de Documentos) & Armazenamento de documentos \\
- Workflow & - Processos com controle \\
- RFID - Radio Frequency Identification & - Identificação dos clientes e logística \\
- Token - Geração de Senhas Dinâmicas & - Segurança \\
\hline
\end{tabular}

Fonte: Adaptado de Thaler - CIAB (2003)

De acordo com estudo realizado pela IBM, sobre o Paradoxo da Indústria Bancária em 2015 (2006), "a tecnologia é aperfeiçoada continuamente para permitir valor alternativo, onde os avanços na conectividade e potencial computacional global criarão e consolidarão as condições de mercado que proverão a especialização nos próximos dez anos. Redes de comunicação, operadas por banda larga e tecnologias sem fio, continuarão a produzir conectividade digital mais rápida, mais acessível e mais interativa, tornando a conexão com parceiros e clientes praticamente sem interrupções". 


\subsection{Conseqüências do Novo Paradigma na Distribuição Bancária}

\subsubsection{Cenário Financeiro Atual}

Em um mercado altamente competitivo, torna-se imprescindível para os bancos a necessidade de melhorar eficiência e reduzir custos.

Neste contexto, são vários os desafios dos bancos para que seus objetivos possam ser atingidos, como a pressão para redução de juros e tarifas, a desregulamentação, a livre concorrência, a interpenetração de mercados e empresas de diferentes segmentos, sem contar com o fato de que os clientes possuem a cada dia uma infinidade de novas opções além da natural elevação do nível de exigência, tornando as demandas cada vez mais complexas;

Segundo estudo realizado pela IBM Institute for Business Value, sobre o Paradoxo da Indústria Bancária em 2015 (2006), "Inevitavelmente, o cenário em questão, remete os bancos a uma reflexão sobre o que, onde e como atender a uma base de clientes cada vez mais informada e exigente. Ao mesmo tempo, uma avalanche de mudanças no setor, incluindo consolidação, regulamentação, especialização do mercado, mudanças das necessidades da força de trabalho e novas tecnologias, está exercendo pressão nos modelos operacionais dos bancos e levantando questões quanto às estratégias tradicionais para crescimento e criação de valor".

O estudo da IBM (2006) conclui que "Uma análise das forças que compõem esse mercado revela que o futuro exigirá extrema eficiência e excelência operacional 
de todos os bancos, enquanto a liderança será conquistada pelas instituições mais inclinadas a adotar a inovação em produtos, serviços e processos, antecipando-se e atendendo às necessidades dos clientes“.

\subsubsection{O Sistema Financeiro Nacional}

O Sistema Financeiro Nacional (SFN) tem suas características notadamente marcadas por fatores internacionais e nacionais. Dos fatores internacionais, o SFN sofre o impacto do processo de globalização das relações em nível de produção e comércio e também da velocidade da integração mundial por meio das redes de comunicação que interligam os centros financeiros.

De acordo com Miranda (2001) "a partir da segunda metade dos anos 90 do século XX, seguindo a tendência de liberação dos fluxos internacionais de capitais, os preços dos ativos financeiros passaram a ser determinados por interações instantâneas entre agentes privados, transacionando volumes de recursos superiores às reservas existentes nos Bancos Centrais, retirando, em boa medida, dos governos nacionais o poder de determinar sua política econômica e expondo os países emergentes a ataques especulativos".

No âmbito nacional, os sucessivos planos econômicos em busca de estabilidade monetária, a reestruturação da economia brasileira iniciada no princípio dos anos de 1990 e a necessidade do país participar mais ativamente do comércio mundial repercutem na dinâmica de funcionamento do SFN. 
O Brasil possui o maior e mais complexo sistema financeiro na América Latina, com 208 bancos, que se distribuem por aproximadamente 17.500 mil agências e cerca de 15 mil postos de atendimento adicionais, mas cujo desenvolvimento foi impulsionado pelo longo período inflacionário com o qual a economia brasileira conviveu ao longo das últimas décadas, de acordo com informações do Banco Central do Brasil (BCB, 2007).

\subsubsection{Tendências da Indústria Bancária}

Por meio de pesquisas de mercado e entrevistas com executivos do setor bancário, o IBM Institute for Business Value (2006) identificou cinco importantes tendências que impactarão a indústria de bancos de varejo para um futuro próximo. “Em 2015, a combinação das implicações dessas tendências criará um ambiente onde não será aceitável nada menos do que um enfoque preciso e excelência nas operações diárias, onde os bancos precisarão gerar crescimento através de inovação contínua, ou ficarão para trás:

\subsubsection{Clientes:}

Definem as novas regras do jogo: Mudanças significativas na demografia, atitudes e comportamento, além da informação onipresente estão dando aos clientes o poder de exigir maior capacidade de resposta e transparência de seus bancos.

\subsubsection{Competidores:}

Bancos Universais e bancos de nichos prosperam: Grandes organizações passarão a gerar lucros agregados mais altos ao obter benefícios de grande escala, enquanto 
instituições de nicho buscarão agressivamente os clientes, atendendo às suas necessidades das mais diversas maneiras.

\subsubsection{Capital Humano:}

Mudanças na força de trabalho exigem novas abordagens: Uma força de trabalho cada vez mais madura e diversificada aumentará a complexidade de gestão, exigindo abordagens flexíveis para compensação e gerenciamento de desempenho.

\subsubsection{Regulação:}

Encargos regulatórios aumentam: Requisitos elevados quanto à privacidade, segurança, risco de parceria e risco operacional exigirão que os bancos pratiquem uma abordagem pró-ativa, em escala corporativa, para gerenciar temas relacionados à conformidade.

\subsubsection{Tecnologia:}

Tecnologia é aperfeiçoada continuamente para permitir valor alternativo: Avançadas tecnologias permitirão que os bancos integrem seus modelos operacionais e infraestruturas de legado, atingindo uma funcionalidade sem precedentes. Tecnologias emergentes extinguirão as filosofias de auto-suficiência em prol de um modelo de alianças estratégicas no qual proliferem as empresas especializadas.

O estudo realizado pelo IBM Institute for Business Value (2006), afirmou que "entre as cinco tendências citadas, as duas primeiras - Clientes cada vez mais incisivos e competição acirrada - destacam-se como as forças significativas que levarão o mercado a mudar na próxima década. As outras três tendências - 
mudanças na administração do capital humano, normas e tecnologias - contribuirão decisivamente e reforçarão os efeitos da competição acirrada e o poder do cliente nas estratégias dos bancos".

O estudo comprovou ainda que "os padrões de decisão dos clientes se tornarão mais complexos. A compra orientada por valor, baseada na dinâmica preçoqualidade, está se tornando cada vez mais influenciada pela visão pessoal e o pelo direito de expressar esse posicionamento abertamente". Os clientes exigirão preços baixos para produtos básicos, mas pagarão mais por produtos e serviços que sejam mais importantes do ponto de vista pessoal, conforme demonstrado na

Figura 15 - Da "Bell curve" à "well curve".

Figura 15 - Da "Bell curve" à "well curve"

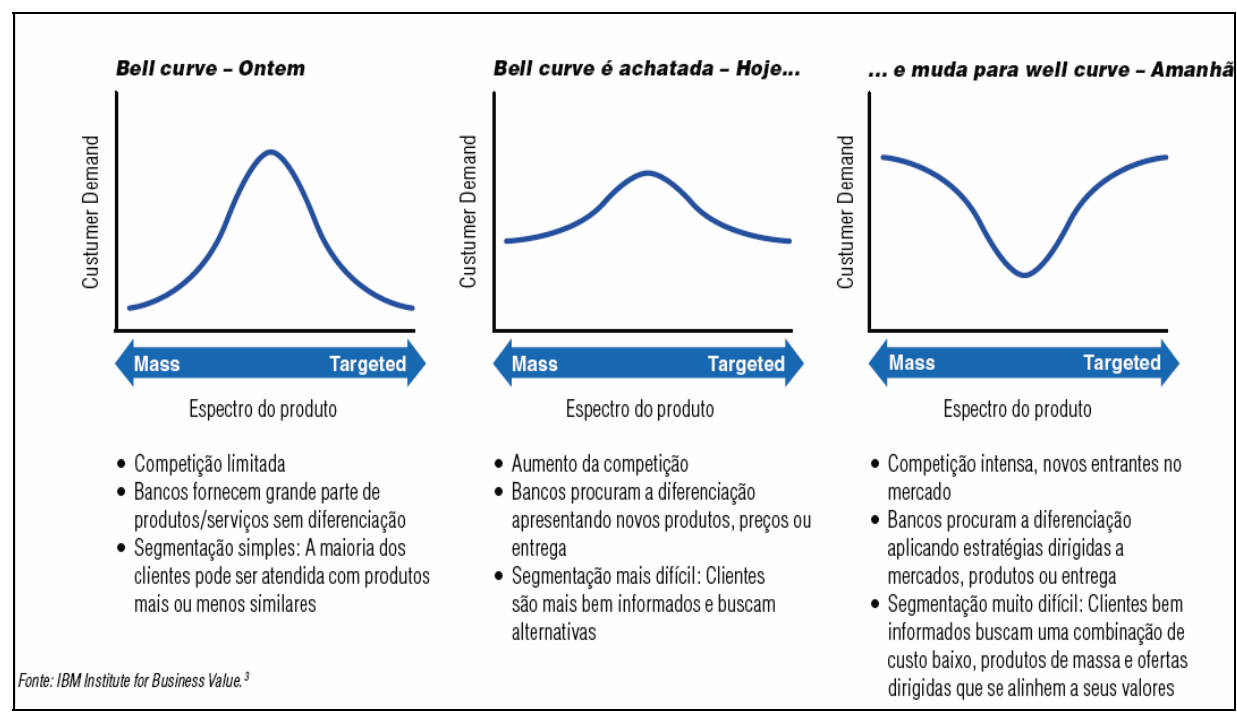

Fonte: O Paradoxo da Indústria Bancária em 2015 - IBM Institute for Business Value

O estudo realizado pelo IBM Institute for Business Value (2006), indicou também que, "para agradar os clientes, os bancos precisarão fornecer maior valor percebido do que seus concorrentes. No futuro será essencial oferecer mais opções 
e personalização de produtos e serviços - e ainda não será o bastante. Para se tornar um verdadeiro interventor do cliente, os bancos precisarão utilizar as informações dos clientes para antecipar-se e sugerir pró - ativamente as soluções bancárias que atendam às necessidades reais e de estilo de vida dos clientes".

Outro indicativo levantado pelo estudo demonstra que "os Bancos universais e instituições de nicho irão prosperar. Em 2015, os resultados de duas proeminentes forças competitivas estarão claramente visíveis: uma "contenção" dos bancos tradicionais, o surgimento de um expressivo número de especialistas da indústria e instituições não-bancárias - cada um com estratégias distintas de crescimento competitivo".

O estudo da IBM identificou também que "o mercado testemunhará a consolidação se continuar a ser afetado pela expansão do alcance dos grandes bancos e pelo surgimento de instituições de serviços bancários especializados, que determinarão novos padrões para custos e serviços. No entanto, as aquisições realizadas por grandes bancos continuarão a ser pouco atraentes até que diminua a distância entre o comprador e a avaliação do alvo potencial". A Figura 16 Transformação do panorama dos serviços bancários de varejo demonstra a tendência de transformação do contexto dos serviços bancários de varejo. 
Figura 16 - Transformação do panorama dos serviços bancários de varejo

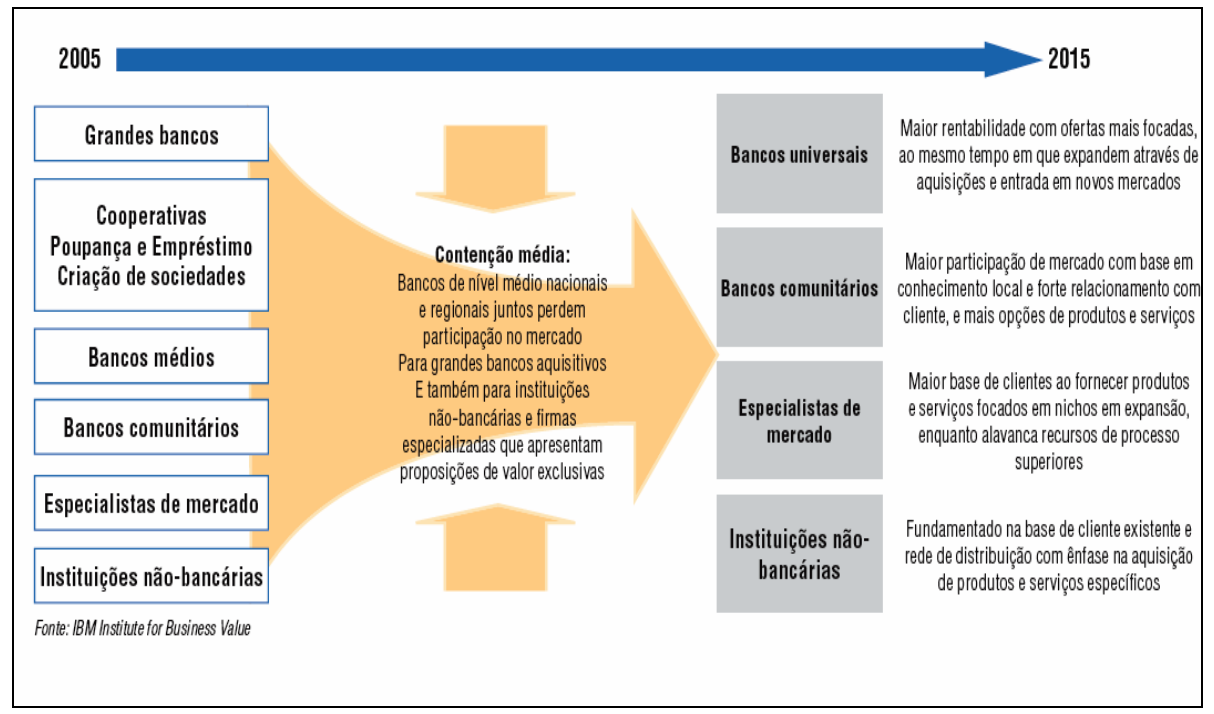

Fonte: O Paradoxo da Indústria Bancária em 2015 - IBM Institute for Business Value

O estudo da IBM conclui que "À medida que as forças as forças competitivas do mercado se intensificarem, certamente os bancos precisarão ser mais responsivos às condições de mudança do mercado e às ameaças competitivas emergentes, sem falar em uma base de cliente mais capacitada. Será necessário que os bancos tomem medidas drásticas para redefinir os modelos de negócios e reunir os melhores recursos do mercado e será necessário se transformar em organizações especializadas com enfoque em componentes de negócios diferenciados dentro da empresa, entregando tarefas não-essenciais para especialistas externos que providenciarão funcionalidade de maneira aberta e flexível".

\subsubsection{Conseqüência do Novo Paradigma na Distribuição Bancária}

No ambiente bancário, não têm sido diferente. A tecnologia vem assumindo cada vez mais importância no relacionamento entre bancos e clientes. Segundo dados apresentados na CIAB (2006), "o número de operações realizadas via 'Internet Banking' e terminais ATM, cresceu 16,9\% entre 2004 e 2005”. 
No ambiente da Internet segundo dados divulgados pelo Ibope em março de 2007, o Brasil atingiu a marca de 25 milhões de usuários domiciliares (Ibope, 2007).

Outro dado relevante divulgado na CIAB (2006) menciona que "enquanto que o atendimento nas agências obteve crescimento de 3\% das transações feitas no caixa; há expectativa de uma forte popularização do Mobile Banking";

O Setor bancário é o que mais investe em tecnologia no país. Em 2005 os bancos brasileiros gastaram mais de 18 bilhões de reais com TI, um aumento de $16,7 \%$ em relação a 2004; segundo dados divulgados em pesquisa realizada pela FGV (2005).

A pesquisa da FGV (2005) destacou ainda que "o setor financeiro foi responsável por 20\% de tudo que foi investido em tecnologia no país; em 2005, um montante superior a $11 \%$ do patrimônio líquido dos bancos investido em TI. O resultado é um foco destacado do setor bancário para operações on-line".

\subsubsection{Canais Remotos de Distribuição Bancária}

Analisando-se as tendências citadas anteriormente, observa-se que as necessidades e o valor percebido pelos clientes quanto à utilização de serviços bancários estarão cada vez mais associados a uma visão de facilidade e comodidade aliadas ao custo mais competitivo e à efetiva qualidade do produto adquirido ou do serviço prestado. 
Neste contexto, os canais de distribuição remotos ganham cada vez mais importância. Hoje, nos grandes bancos de varejo, aproximadamente $85 \%$ de todas as transações bancárias são realizadas nos canais remotos, tornado-os merecedores do título de canais preferências de relacionamento. Essa realidade reforça a importância da comunicação digital citada pela grande maioria dos especialistas apresentados nesse capítulo (Febraban, 2006).

Porém, somente a tecnologia não irá prover as condições necessárias para atender as expectativas dos clientes. Tendo em vista que a revisão e adequação dos processos internos dos bancos, assim como a qualificação das pessoas, aliados ao conhecimento sobre o comportamento dos clientes farão com que a conveniência, a praticidade e a segurança no relacionamento, candidatem-se a melhor atender as expectativas dos clientes.

O suporte da mais alta tecnologia permitida pela automação da plataforma bancária poderá convergir de acordo com a necessidade de cada cliente para o tipo de atendimento que Ihe seja mais conveniente, chegando ao atendimento personalizado por meio de um Call Center, ou até mesmo de uma vídeo conferência envolvendo o gerente de sua agência, um especialista de investimentos, o operador do Call Center, culminando em uma visita pessoal de seu Gerente de Relacionamento para concretizar o negócio ou simplesmente o envio de um courier para a assinatura de um documento. 


\subsubsection{Ação Sobre a Visão do Cliente}

Considerando-se o imperativo de minimização do custo de servir imposto aos bancos, cuja natural conseqüência é o incentivo ao uso dos canais eletrônicos, há que se agir sobre a natural preferência dos clientes que é a realização das transações via atendimento humano.

O emprego da tecnologia somente resulta bem sucedido quando a aplicação da mesma se faz à semelhança da natureza humana. Nessas circunstâncias, há um desafio a ser superado que é o de se dotar o canal eletrônico de um elenco de atributos que permitam a percepção de um valor por parte do cliente capaz de promover uma mudança em seu hábito de uso do banco na realização de suas transações. Ações que promovam essa percepção de valor estão alinhadas com a apresentação de soluções que embutam conveniência, facilidade de uso e segurança em seu composto, resultando dessa maneira numa migração bem estruturada, conforme se apresenta na Figura 17 - Ação sobre a visão do Cliente que combina as visões anteriores e posteriores à migração.

Figura 17 - Ação sobre a visão do Cliente

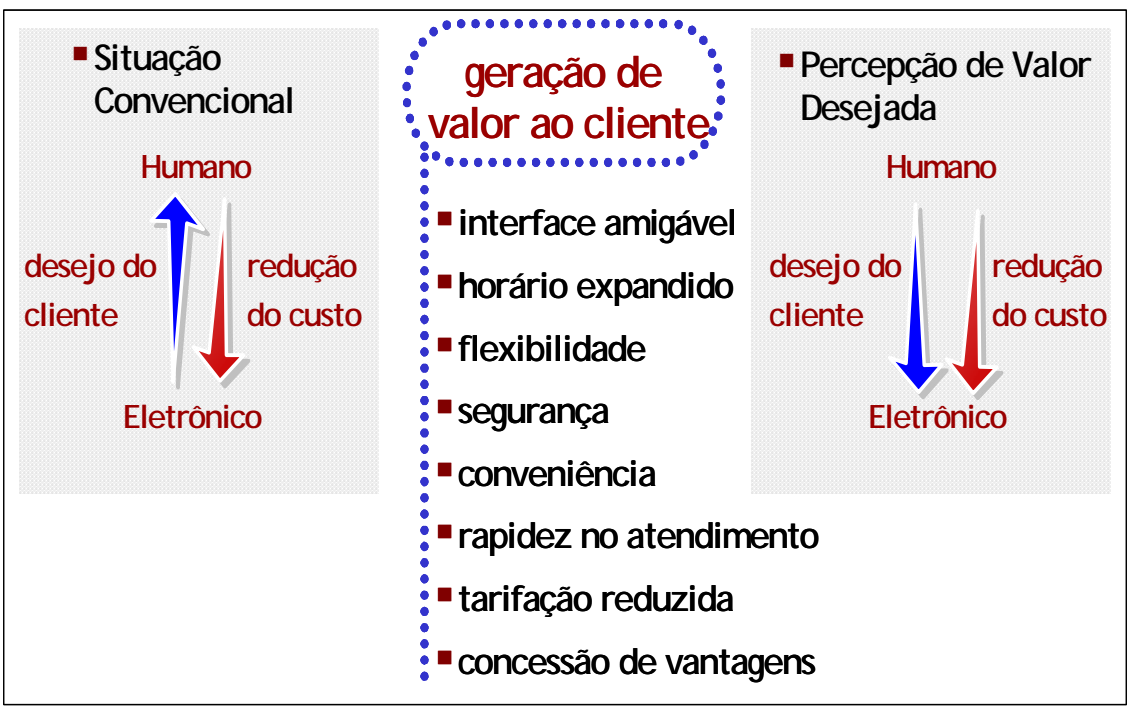


É portanto um grande desafio conjugar-se os componentes de geração de valor para os clientes, conforme mencionados no exemplo da Figura 17, para a promoção da mudança da forma de se realizar transações com o banco, compatibilizando interesses e atendendo expectativas de ambos, banco e cliente.

Para isso, os bancos deverão estar dotados de condições tecnológicas para captar de cada um de seus clientes, suas reais expectativas, onde as ferramentas de CRM e database sem dúvida terão papel preponderante para apoiá-los nesse empreendimento.

Neste contexto, os recursos humanos desempenham papel principal, pois a força de trabalho da Organização deverá estar totalmente preparada para apoiar esse processo, fazendo com que soluções tecnológicas, conhecimento adquirido, produtos e serviços customizados e adaptados a cada público ou perfil de cliente, transformem-se em ações efetivas, onde independente do canal a ser utilizado pelos clientes, a interação humana tenha a possibilidade de ser bem sucedida, ao transformar os contatos dos clientes em oportunidades de negócio.

Será o relacionamento o grande diferencial, pois a cada nova interação do cliente com o banco, a cada novo dado armazenado sobre seus hábitos de consumo, uma pessoa do outro lado (que poderá representar um efetivo contato pessoal, telefônico ou até mesmo um processo estruturado) representando a Organização, deverá entender, organizar e direcionar adequadamente cada uma dessas ações e planejar suas próximas interações, acompanhando adequadamente todo o ciclo de relacionamento com os clientes, pois as necessidades de consumo 
são extremamente dinâmicas e mutáveis, de cliente para cliente, uma vez que a mesma tecnologia que apóia os bancos em suas tomadas de decisão, também norteia e direciona muitas das ações dos clientes, tornando-os cada vez mais exigentes.

\subsubsection{Convergência e Mobilidade}

Segundo Friedman (2005), o mundo está vivenciando uma tripla convergência. A primeira começou acontecer por volta do ano 2000, quando as empresas começaram a perceber que alguns processos e tecnologias demonstravam-se estáveis, a ponto de viabilizar modificações em si próprios, ou mesmo, possibilitar a realização de serviços de maneira colaborativa, tanto com empresas que atuavam em atividades complementares ou com seus próprios clientes.

Inúmeros exemplos dessa convergência podem ser mencionados, como a convergência entre software e hardware de fluxo de trabalho, que possibilitou à Konica Minolta oferecer recursos de scanner, e-mail, impressão, fax e fotocópia no mesmo equipamento.

Temos ainda o exemplo de algumas companhias aéreas que de forma colaborativa, permite que seus clientes possam baixar e imprimir seus próprios cartões de embarque em casa pela Internet.

De acordo com Friedman (2005), "o resultado final dessa convergência foi a criação de um campo de jogo global, mediado pela web, que viabiliza diversas 
modalidades de colaboração (isto é, o compartilhamento de conhecimento e trabalho) em tempo real, independentemente da geografia, distância ou, num futuro próximo, até mesmo de idioma. Não, nem todos tem acesso ainda a tal plataforma, a esse campo de jogo, mas ele hoje está mais aberto, para mais pessoas, de mais lugares diferentes, durante mais tempo e de uma maior variedade de formas do que em qualquer momento anterior da história do mundo".

A segunda convergência está relacionada diretamente à maneira de como se daria o processo de colaboração entre indivíduos de uma mesma empresa ou de diferentes organizações e seus clientes, todos interagindo em um cenário novo e extremamente dinâmico.

Segundo Friedman (2005), "Era preciso que surgisse uma massa crítica de gerentes, inovadores, especialistas em TI, principais executivos e profissionais familiarizados com e capazes de desenvolver as modalidades de colaboração horizontal, processos de criação de valor e hábitos que lhes permitiriam tirar proveito do novo terreno mais nivelado".

Outro exemplo que define bem esse tipo de colaboração pode ser citado com a recente colaboração entre as empresas HP, Cisco e Nokia, que trabalharam conjuntamente no desenvolvimento de uma câmera/telefonia celular que transmite (sem necessidade de cabos) suas fotos digitais para impressão imediata por uma impressora HP. Nesse exemplo, Friedman (2005) cita que "cada uma das empresas havia desenvolvido uma tecnologia sofisticadíssima dentro de sua própria 
especialidade, mas só foi possível agregar valor mediante sua combinação horizontal".

A terceira convergência relatada por Friedman (2005) menciona a entrada abrupta de 3 bilhões de pessoas com possibilidade de competir e colaborar com todo o resto do mundo. São indivíduos provenientes da China, Índia, Rússia, Leste Europeu, América Latina e Ásia Central, que a partir da década de 1990, viram seus sistemas políticos e economia se abrirem, o proporcionando a seu povo a uma crescente liberdade para acesso ao jogo do livre mercado.

Friedman (2005) conclui que "essa tripla convergência - de novos jogadores, num novo campo de jogo, desenvolvendo novos processos e hábitos para a colaboração horizontal - que constitui, a meu ver, a força mais significativa a moldar a economia e a política globais neste início do século XXI. O fato de tanta gente ter todas essas ferramentas de colaboração a seu dispor, aliado à possibilidade de acessar, por meio de motores de busca e da Web, bilhões de páginas de dados brutos, vai garantir que a próxima geração de inovações venha de todos os cantos da Terra Plana. Toda a comunidade global logo poderá tomar parte de descobertas de todos os tipos, e o grau de inovação atingirá patamares jamais vistos antes".

Segundo o contexto de que o relacionamento tem papel preponderante na dinâmica cliente $\mathrm{x}$ banco, outro aspecto fundamental para os bancos diante da nova economia digital, será o aproveitamento adequado do fluxo pré-identificado dos clientes. Ao se obter as informações dos clientes em tempo real a cada nova interação, independente do canal de relacionamento que utilizar (Internet, Auto- 
atendimento, Agência, Mobile Banking, Call Center), ter-se-á meios de efetivamente consolidar o aprendizado sobre suas necessidades e hábitos de utilização.

Partindo do pressuposto de que atualmente os grandes bancos possuem essas informações sobre as interações dos clientes em cada um dos canais de relacionamento, o novo desafio a ser lançado será a possibilidade de convergência de todos esses canais.

A plataforma tecnológica de atendimento deverá necessariamente possuir funcionalidades multicanal, permitindo além da comunicação entre eles, total interatividade em tempo real, partindo de qualquer ponto de contato com a empresa, a qualquer momento, permitindo que os clientes possam acessar serviços disponíveis e complementares de outros canais, convergindo, por exemplo, de um contato iniciado em uma unidade de auto-atendimento, para o diálogo com um operador do Call Center, tendo condições de solucionar todas as suas demandas em um único contato.

Essa nova ótica de relacionamento permitirá a efetiva valorização dos clientes, de modo que possam perceber que existe verdadeira preocupação do banco, não somente em atendê-los de maneira rápida, segura e flexível, mas também, de antecipar-se às suas necessidades que podem ou não estar associadas ao âmbito dos serviços e produtos bancários.

Partindo de uma plataforma analítica de inteligência de negócios, os bancos terão uma infinidade de possibilidades a serem trabalhadas, considerando-se que 
possuem esse valioso ativo, que é a maneira correta de utilizar-se do fluxo préidentificado dos clientes, para, por exemplo, alertá-los sobre compromissos importantes, ofertar produtos e serviços customizados para suas necessidades, estabelecer parcerias com empresas que desejem colocar seus produtos e serviços (não bancários) à disposição dos clientes do banco, com condições e preços de aquisição diferenciados, fornecer informações de caráter público sobre utilidades em geral, informações de entretenimento entre outras.

O objetivo central de toda essa interatividade será o de oferecer aos clientes uma experiência de relacionamento única e extremamente diferenciada com alto valor agregado.

Figura 18 - Convergência e Mobilidade

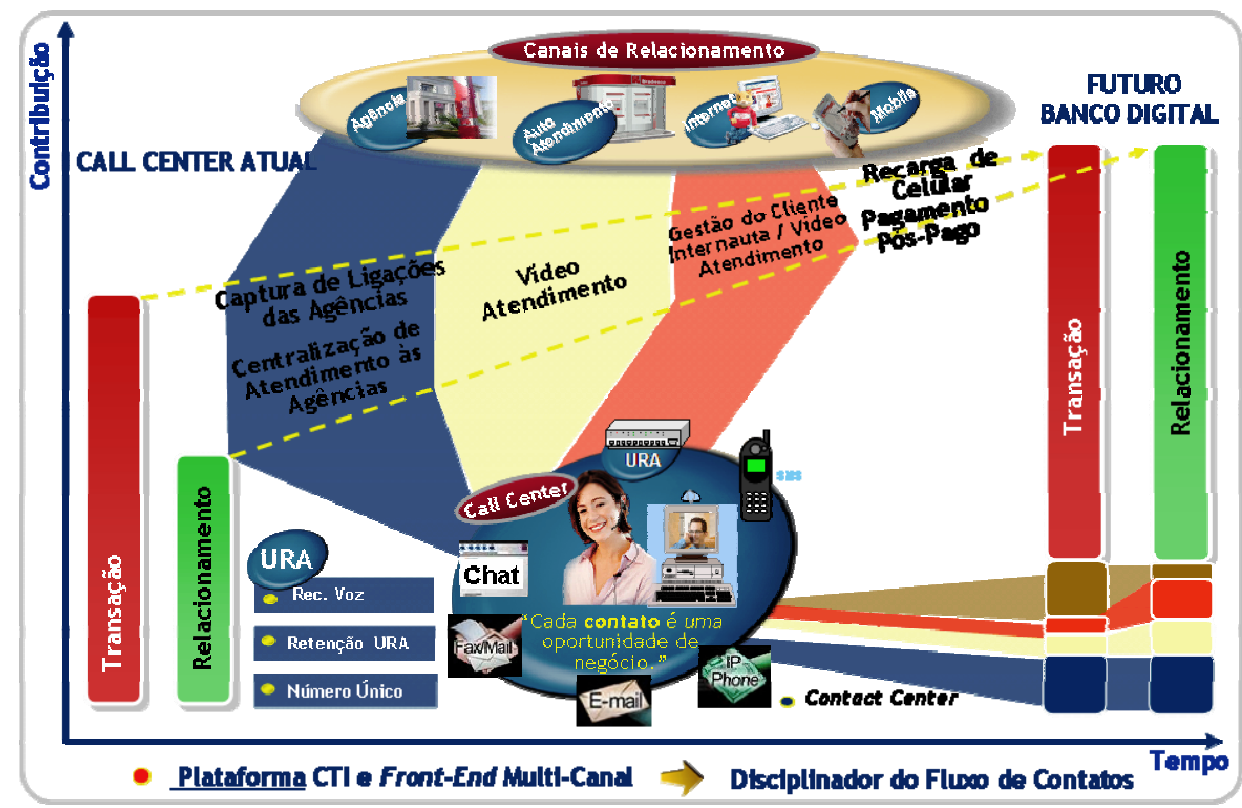

A Figura 18 - Convergência e Mobilidade representa o potencial de utilização do conhecimento dos clientes, aliado aos canais de relacionamento mais adequados a realização de cada transação, ilustrando que a convergência e a mobilidade são 
as duas vertentes essenciais que irão reconfigurar todo o processo e a logística da distribuição bancária.

A economia digital, em outros termos, fará com que todos os canais de relacionamentos com os clientes - Internet, auto-atendimento, mobile banking, agências, Call Center entre outros - convirjam para um só lugar, trazendo os clientes, onde quer que estejam para o Contact Center, onde há especialistas para prestar os mais variados tipos de serviços.

Essa será a grande vertente para a construção de relacionamentos sólidos entre clientes x bancos - Convergência digital dos canais de relacionamento. Para tal, mesmo as funções de contato eletrônico, deverão possibilitar a interação de maneira agradável, conveniente e segura, fato que impulsiona os clientes para o uso dos canais, buscando ao máximo assemelhar-se à natureza humana.

\subsubsection{Ciclo do Novo Canal}

Como conseqüência dessa nova dinâmica de interatividade possibilitando contatos dos clientes pelos múltiplos canais, enquanto o número de transações se eleva, intensifica-se a contribuição dos resultados financeiros, fortalecendo o relacionamento entre cliente x banco, conforme ilustrado na Figura 19 - Ciclo do Novo Canal. 
Figura 19 - Ciclo do Novo Canal

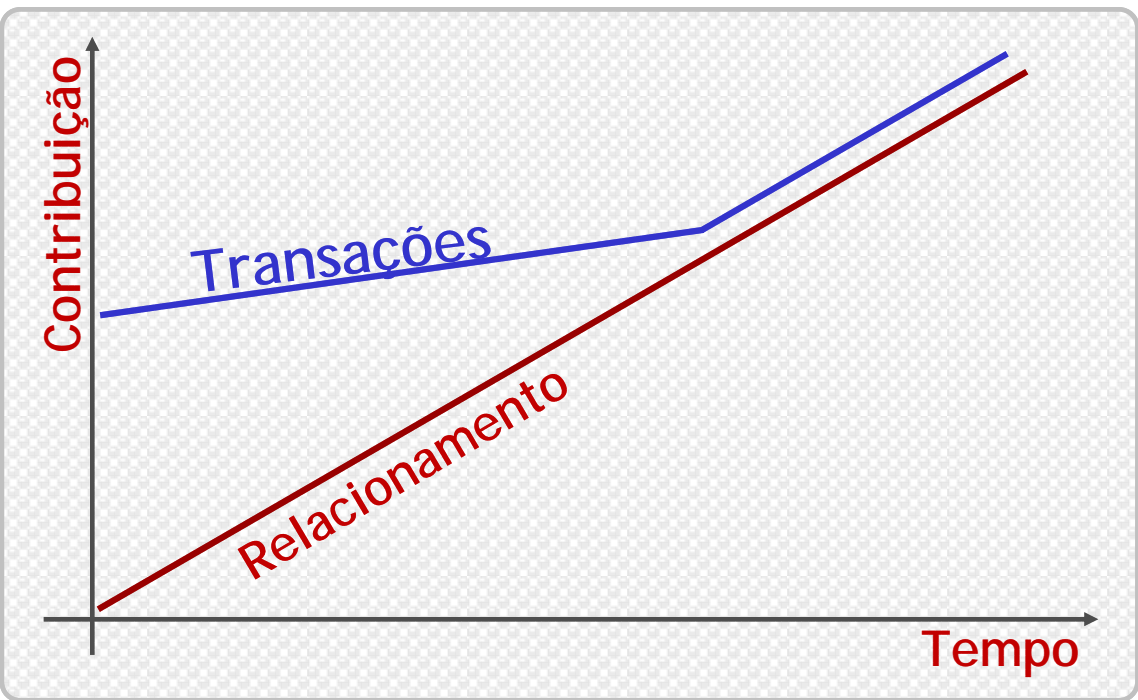

Quando o cliente passa a utilizar mais intensamente os canais para realizar suas transações surge a oportunidade de se evoluir no eixo de relacionamento, buscando-se otimizar os contatos dos clientes nos canais.

O modelo de gestão múltipla dos canais de relacionamento pressupõe que o alicerce para construção do mesmo, parte do Call Center, que se presta à função de administrar o processo de migração das transações de natureza repetitiva do ambiente das agências para os demais canais, cujo movimento é basicamente motivado pela conjugação de interesses do banco que se recompensa pela redução do custo unitário das transações e do cliente que passa a se servir dos serviços de maneira mais conveniente.

No Contact Center, o processo de contribuição para a geração de receita para o banco terá início ao utilizar-se adequadamente das ferramentas de CRM, aproveitando o fluxo de clientes pré-identificados para transformar os contatos recebidos em oportunidades de negócio. 
Partindo de uma base de dados analítica "Data Mining" que contém o histórico de inúmeras informações dos usuários dos canais de relacionamento, é realizado um trabalho de exploração, identificando necessidades de correções, para normatização das informações.

Em seguida, essa mesma base de dados sofre uma modelagem, utilizando-se para tal, softwares específicos que possibilitam o desenvolvimento de cálculos probabilísticos que envolvem inúmeras variáveis como comportamento de consumo, demografia, informações sócio-econômicas, permitindo a criação de modelos de propensão de consumo para os variados públicos, de acordo com o tipo de canal de relacionamento que utiliza.

Essas informações são armazenadas em outra base de dados operacional que possibilita a interatividade multicanal cliente-banco e no momento da realização de uma transação haverá possibilidade de uma interação pró-ativa em todos os canais de relacionamento, permitindo a oferta de produtos e serviços customizados para as necessidades dos clientes.

A Figura 20 - Modelos de Propensão representa de forma simplificada, como se dá o processo de análise de propensão para oferta de produtos aos clientes usuários dos canais de relacionamento, com o intuito de se obter um melhor índice de sucesso nas vendas, levando-se em consideração o segmento dos clientes e demais características dos públicos, bem como de nichos específicos em um mesmo segmento que originarão novos clusters. 


\subsubsection{Modelos de Propensão}

Figura 20 - Modelos de Propensão

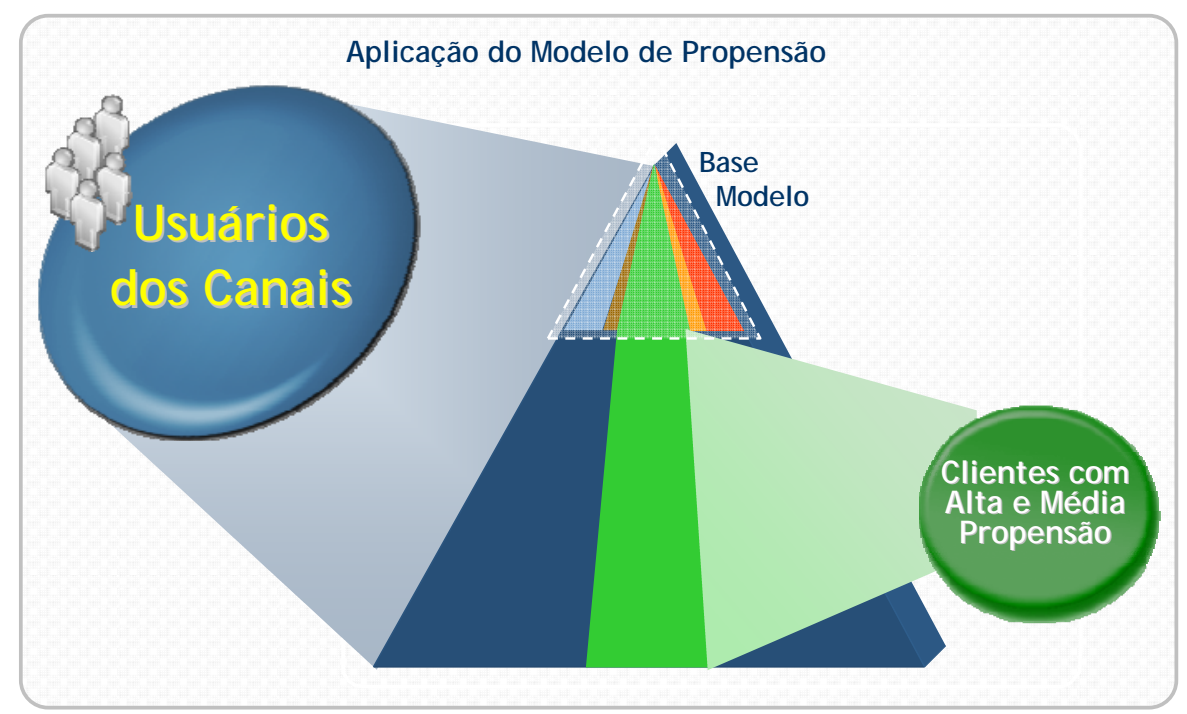

Os modelos de propensão permitem que se obtenha alto índice de assertividade nas ofertas por tipo de canal, cliente e produto, tornando o processo extremamente produtivo e eficaz.

Devido à velocidade de mudanças nas variáveis adotadas para a realização dos modelos de propensão, demanda-se a necessidade constante de realimentação do processo, o que torna contínua a análise dos dados, bem como freqüente o monitoramento dos índices de sucesso de cada uma das ações multicanal implementadas.

A Figura 21- Ciclo de Relacionamento representa o processo de relacionamento com os clientes, os requerimentos necessários para a adequada realimentação do modelo e o monitoramento dos índices de sucesso de cada campanha por tipo de canal. 


\subsubsection{Ciclo de Relacionamento}

Figura 21- Ciclo de Relacionamento

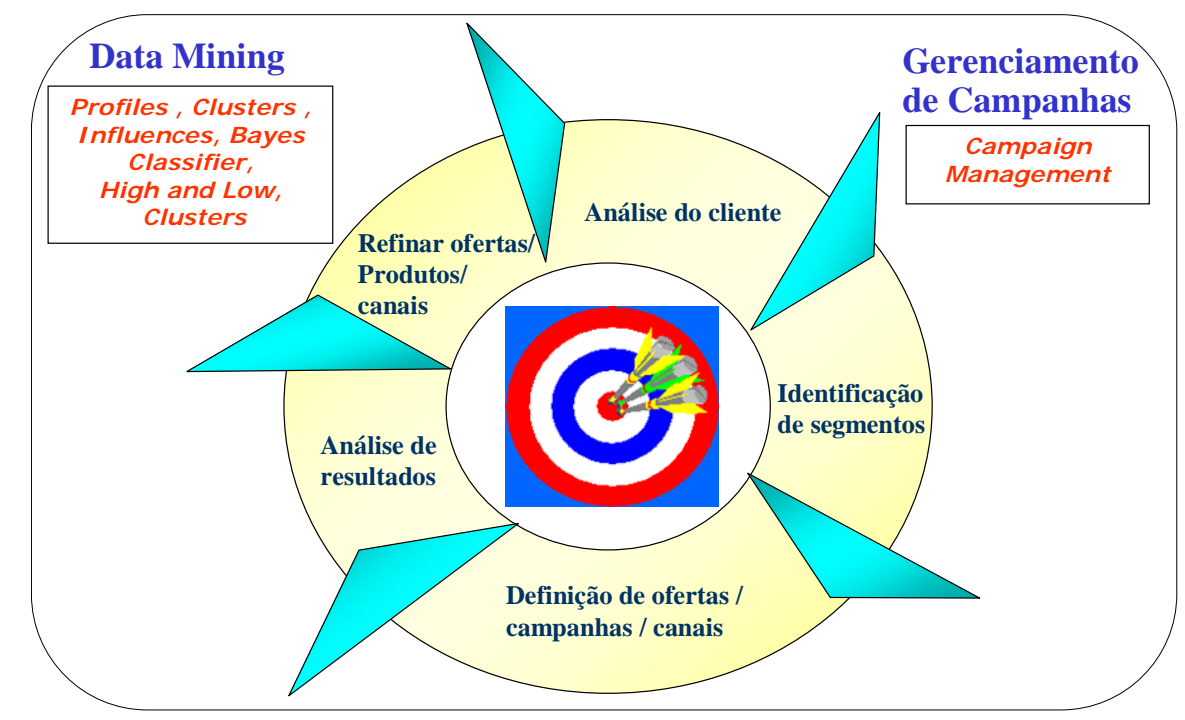

Fonte: Adaptado de KOTLER e ARMSTRONG (2003).

A efetiva manutenção do ciclo de relacionamento permitirá maior êxito nas ações, pois quanto maior for o histórico dos clientes e de suas interações maior será o conhecimento dos mesmos, favorecendo o refinamento das campanhas e elevando-se os índices de assertividade e produtividade.

Todo esse potencial confere ao banco uma poderosa ferramenta estratégica, pois a análise estruturada do comportamento do consumidor, considerando as informações disponíveis nos diferentes ambientes de atividade dos mesmos, acrescidos de dados econômicos, conjunturais e demográficos dota a organização de um valioso modelo preditivo da propensão de comportamento dos consumidores de serviços da indústria bancária. 
Um exemplo específico desse potencial em um grande banco de varejo no Brasil é demonstrado na Figura 22 - Interação com o Cliente Call Center, que representa a tela de atendimento de visualizada pelo atendente no Call Center.

Figura 22 - Interação com o Cliente Call Center

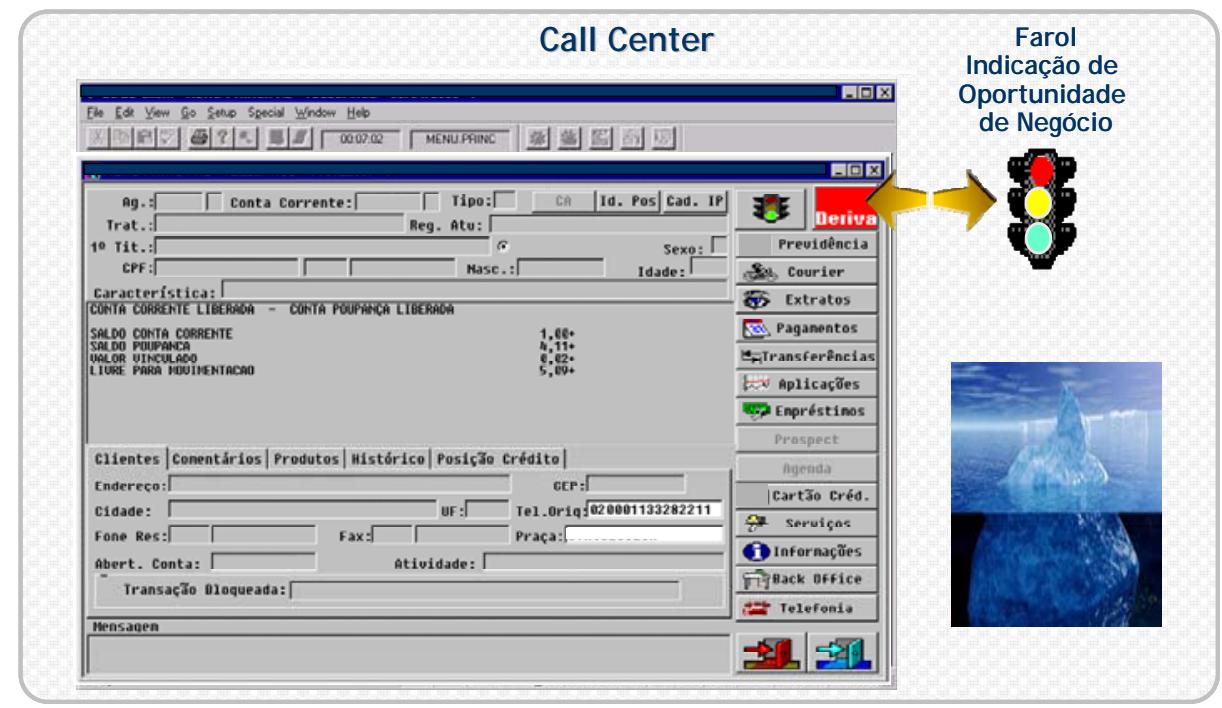

A ferramenta permite total interatividade e fornece ao atendente o histórico de relacionamento dos clientes nos canais, bem como informações úteis para o atendimento de maneira amigável e simplificada.

Ao término do contato o atendente, mediante a permissão do cliente, poderá ofertar produtos ou serviços da organização que forem adequados de forma personalizada para aquele cliente.

O atendente recebe a sinalização de que existem ofertas para o respectivo cliente no início do diálogo quando há um indicativo semafórico posicionado no canto superior direito de sua tela de atendimento. 
Além de informar as condições oportunas para a abordagem de um cliente específico, a função do indicativo semafórico também é a de informar o atendente se o momento da oferta é oportuno diante de outras variáveis como, por exemplo, se não existe outro cliente aguardando para ser atendido, pois como as ofertas ocorrem no Call Center receptivo, a prioridade será sempre atender a demanda e os serviços voluntariamente requisitados pelos clientes.

Toda a inteligência de interatividade e informações dos clientes está contida na base de dados multicanal operacional, representada na figura 22, pela base do iceberg, pois dela serão extraídas todas as informações em nível analítico, para chegar a até o atendente de forma extremamente ágil e simplificada, somente a indicação de oportunidade de negócio para o cliente e se o momento é oportuno para se fazer a abordagem comercial.

A grande vantagem competitiva desse processo é a possibilidade de otimizar as oportunidades de relacionamento com os clientes, que diante do potencial de compra dos produtos em relação ao canal mais adequado para aquisição possibilita uma economia significativa, pois minimiza os esforços já que concentra as abordagens em um público que possui elevada propensão para aquisição do produto, conciliando os benefícios e a comodidade do canal de relacionamento mais adequado para a realização do negócio.

A Figura 23 - Potencial para Ações de Vendas, representa o grau de alavancagem que se pode obter, comparando-se a realização de ofertas em um processo aleatório e não estruturado com um processo no qual a seleção do público 
que irá receber as ofertas é composto apenas daqueles com alta propensão para aceitá-las, apoiado em ferramentas de CRM multicanal.

\subsubsection{Potencial para ações de Vendas}

Figura 23 - Potencial para Ações de Vendas

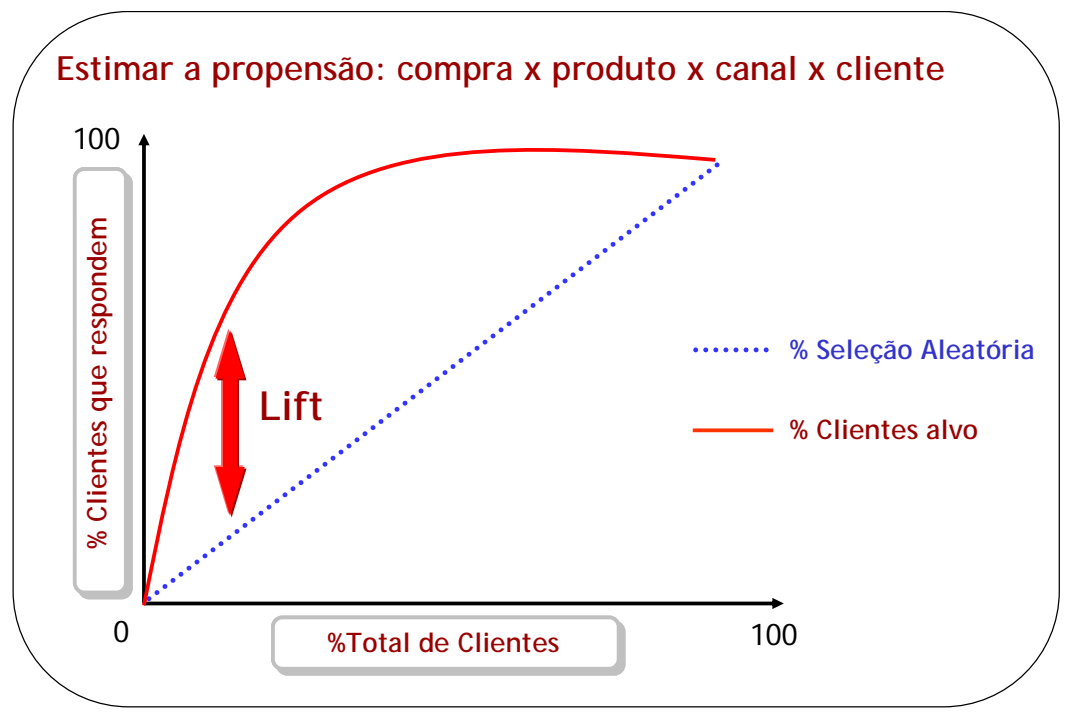

A perspectiva de utilização multicanal da ferramenta de CRM confere ao banco a possibilidade de gerir de forma integrada seus canais de relacionamento e identificar a melhor maneira de atender as necessidades dos clientes numa visão que conjugue o cliente, seu canal de contato e o produto mais adequado à necessidade a ser atendida, conforme demonstra a Figura 24- Aplicação do CRM para a Otimização do Relacionamento Cliente x Banco., permitindo uma visão única dos clientes independente do canal de sua preferência ou comodidade para relacionamento.

Essa otimização do relacionamento resultará em benefícios recíprocos, pois o banco dentro do conceito de diferenciação terá condições de aprimorar cada 
vez mais os serviços e entender adequadamente a demanda de seus clientes, antecipando-se às suas necessidades e entregando um serviço que possa verdadeiramente agregar valor ao relacionamento, visando a maior permanência dos clientes em sua base.

\subsubsection{Gestão Integrada}

Figura 24- Aplicação do CRM para a Otimização do Relacionamento Cliente x Banco.

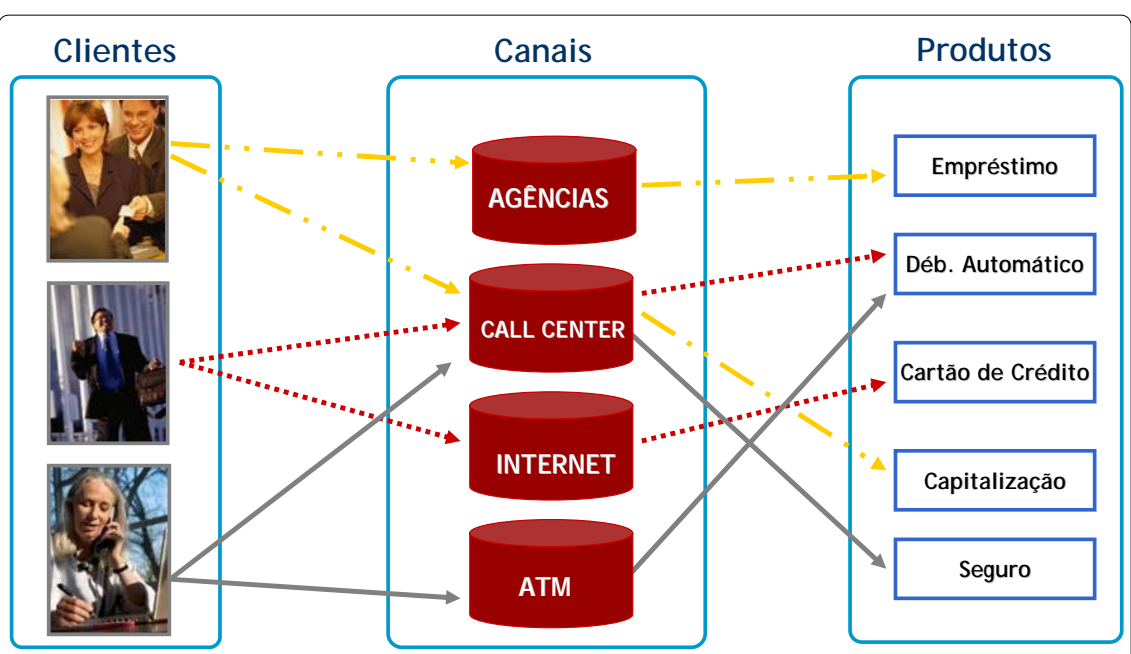

Fluxo de clientes pré-identificados $\Rightarrow$ Maior Patrimônio

O grande diferencial desse processo na indústria bancária é o fluxo préidentificado dos clientes, pois além de permitir a conciliação total da inteligência de marketing, suportada pelas ações citadas nos processos de Data base Marketing, CRM e Business Inteligence e refletidas nos modelos de propensão de vendas, o fluxo de clientes usuários dos canais de relacionamento remotos é significativamente superior ao do mundo físico, não sendo perceptível aos clientes as ações e estratégias adotadas pelo banco que irá antecipar suas necessidades e diferenciálos de acordo com sua categoria. 
A Figura 25 - Gestão Integrada procura transpor para o mundo físico a dinâmica disponível no mundo eletrônico, buscando reproduzir o processo de gestão integrada numa situação de compra na qual um cliente que se dirige a um shopping center para comprar um presente para a esposa e já a partir de seu ingresso no estacionamento, inicia-se uma série de ações personalizadas, de modo a diferenciar sua experiência de consumo.

Figura 25 - Gestão Integrada

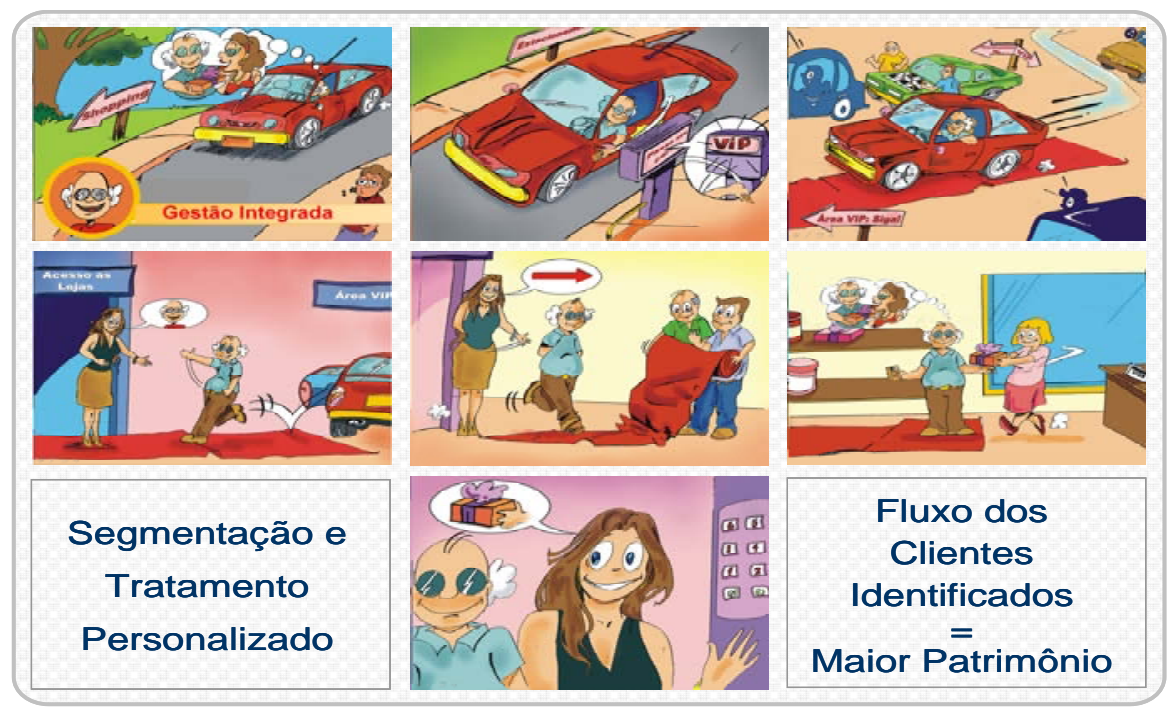

Por ser um cliente considerado VIP, tem acesso exclusivo ao estacionamento com manobrista, sendo prontamente recepcionado na loja de sua preferência, pela vendedora que já o conhece tratando-o, conseqüentemente, de maneira cortês, ágil e objetiva, pois conhece suas preferências e infere com alta propensão de acerto o que o mesmo deseja adquirir.

Ele é literalmente recebido com "tapete vermelho", aceita rapidamente sugestão apresentada pela vendedora e utiliza seu cartão de crédito da própria loja, com concessão de benefícios e programa de fidelidade personalizado, efetuando o 
pagamento, fato que trará à loja mais um registro importante a ser armazenado em sua base de dados, elevando ainda mais o conhecimento sobre seu cliente e seus hábitos de consumo.

No mundo físico, entretanto, não é simples do ponto de vista tecnológico administrar-se o fluxo pré-identificado de clientes, pois ainda não se justificou de forma econômica os investimentos que seriam necessários para se criar uma plataforma tecnológica que permitisse a pré-identificação do cliente e sua conseqüente ação comercial.

No ponto de venda físico há também outros aspectos da relação de consumo que necessitam de exame, tais como as diferentes abordagens estratégicas de comunicação e marketing que permitem transformar a experiência de consumo em uma agradável interação, constituindo-se por diversas vezes em requisito fundamental e preliminar ao início do processo de relacionamento.

De acordo com Underhill (1999), é necessário levar em consideração um princípio básico por trás da ciência das compras: Deve-se atender às necessidades fundamentais e de forma amigável, às especificações do animal homem, levando-se também em conta outras variáveis além das diferenças óbvias entre os consumidores, baseadas no sexo, idade, renda e gostos.

Witt (1991), com o propósito de complementar o modelo de comportamento econômico, incorporou conceitos extraídos da sociobiologia, ressaltando sua contribuição para a psicologia comportamental. 
Também Güth e Yaari (1992) examinam a Teoria das Preferências e observam que fatores naturais e culturais contribuem para o entendimento do comportamento econômico.

Grossmann (2002) sustenta que normas de comportamento, geralmente aceitas podem ser interpretadas como opções racionais de um processo de tomada de decisão.

Yaari e Bar-Hillel (1984) avaliam o comportamento econômico e ao realizarem estudos empíricos concluem que um julgamento justo é função de uma série de fatores, entre os quais necessidades pré-existentes e preferências das partes envolvidas no processo decisório.

Segundo Underhill (1999), "é possível prever ou mesmo determinar como e onde as pessoas andarão - de que vamos por caminhos previsíveis e aceleramos, diminuímos a marcha e paramos em resposta ao nosso ambiente. As implicações de tudo isso são claras: onde os fregueses vão, o que vêem e suas respostas determinam a própria natureza de sua experiência de compra. Eles verão mercadorias e os sinais com clareza ou não.

De acordo Underhill (1999), os potenciais clientes "alcançarão os objetos com facilidade ou dificuldade. Eles percorrerão as áreas calmamente ou com rapidez - ou simplesmente não as percorrerão. E todos esses fatores fisiológicos e anatômicos, entram em ação simultaneamente, formando uma complexa matriz de 
comportamentos que precisa ser compreendida para que o ambiente varejista se amolde com o sucesso ao animal que faz compras".

O autor (op.cit.) conclui que "a lição ampla que aprenderemos com a ciência das compras é: amenidade e rentabilidade estão total e indissoluvelmente ligadas. Cuidando-se da primeira, em todos os seus aspectos, garante-se a última. Construa e opere em um ambiente varejista adaptado às necessidades altamente específicas dos fregueses e você terá criado uma loja de sucesso".

Além disso, independente dos esforços desenvolvidos pela loja, haverá inevitavelmente uma limitação, já que o número de clientes que poderá ser tratado de maneira diferenciada será muito reduzido, dada a imprevisibilidade do modelo de relacionamento, fato que é facilmente superado no modelo de relacionamento remoto, que dependendo do tipo de negócio, poderá atender inúmeros públicos dos mais diversificados segmentos de maneira praticamente ilimitada.

Esse exemplo fica evidenciado nas figuras 26 e 27, onde comparamos primeiramente na Figura 26 - Relacionamento dos Clientes - Canais Físicos, o fluxo de clientes representando os inúmeros públicos e segmentos relacionando-se em sua agência física.

Exatamente para que não haja nenhum tipo de constrangimento para os clientes, não existe condição de segmentar o atendimento para cada tipo de público, o que acaba prejudicando o relacionamento com todos os clientes, independente da rentabilidade que cada um proporciona ao banco. 
Figura 26 - Relacionamento dos Clientes - Canais Físicos

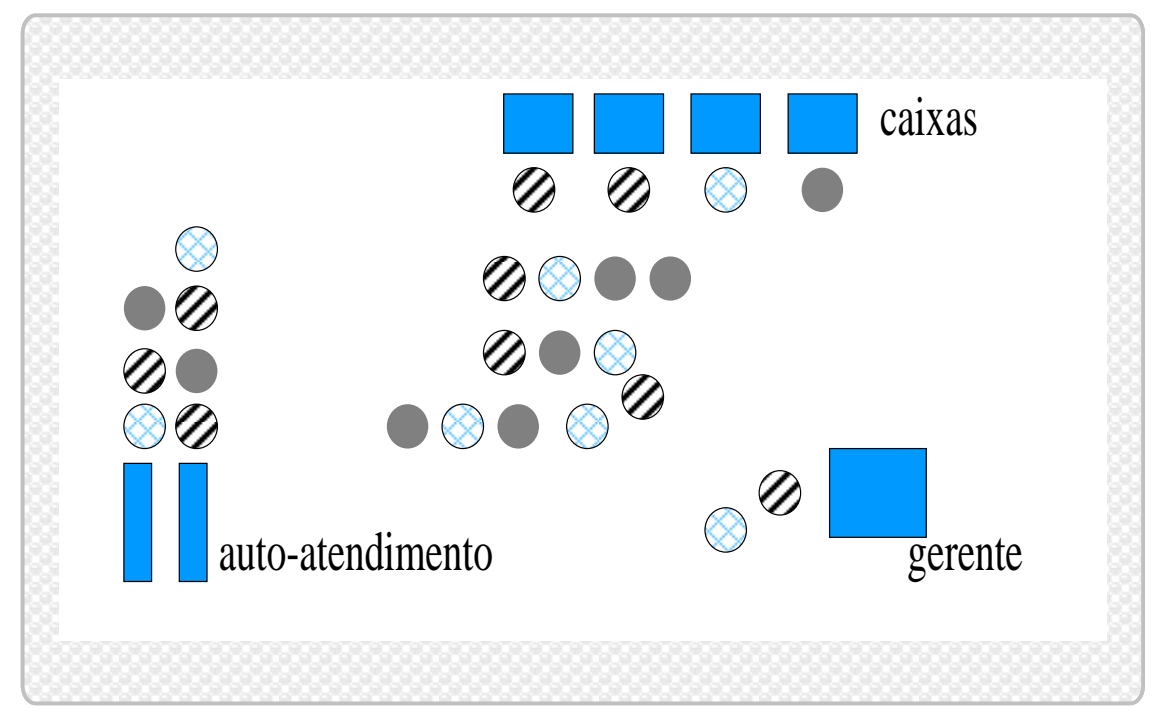

Porém, quando analisamos a ilustração fictícia do fluxo de clientes se relacionando, por exemplo, no Call Center do mesmo banco, representado pela

Figura 27 - Relacionamento dos Clientes - Canais, devido a vantagem de se ter a condição de pré-identificar os clientes, pode-se conseqüentemente realizar uma reorganização na prioridade do atendimento, bem como, identificar especialistas para atender às demandas específicas, de forma imperceptível para os clientes, permitindo total conveniência e satisfação. 
Figura 27 - Relacionamento dos Clientes - Canais

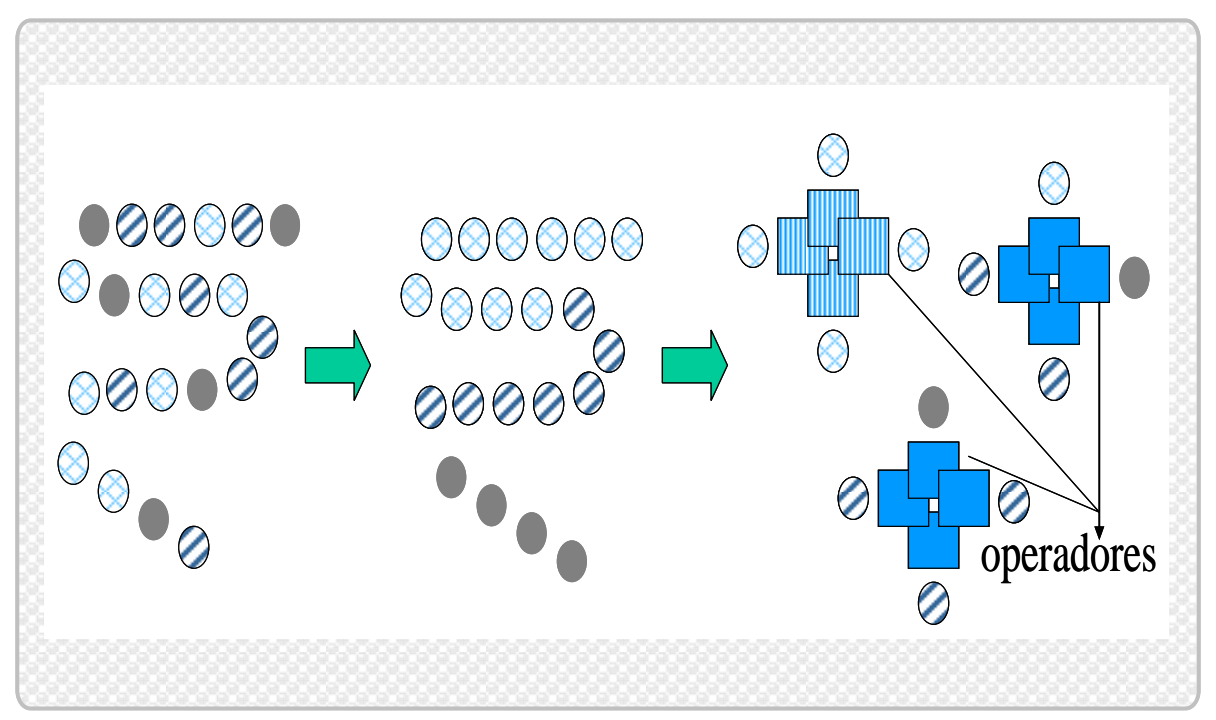

É importante ressaltar o destaque dado à criação de valor na relação empresa-cliente inserido nesse conceito, servindo de suporte para a vinculação e o prolongamento da vida útil do cliente para a empresa, conforme se observa na Figura 28 - Maximização das oportunidades do ciclo de Relacionamento ClienteBanco, na qual a gestão integrada dos canais de relacionamento com os clientes aliada à uma política de concessão de benefícios incrementam o resultado e o tempo de relacionamento com os clientes. 
Figura 28 - Maximização das oportunidades do ciclo de Relacionamento ClienteBanco

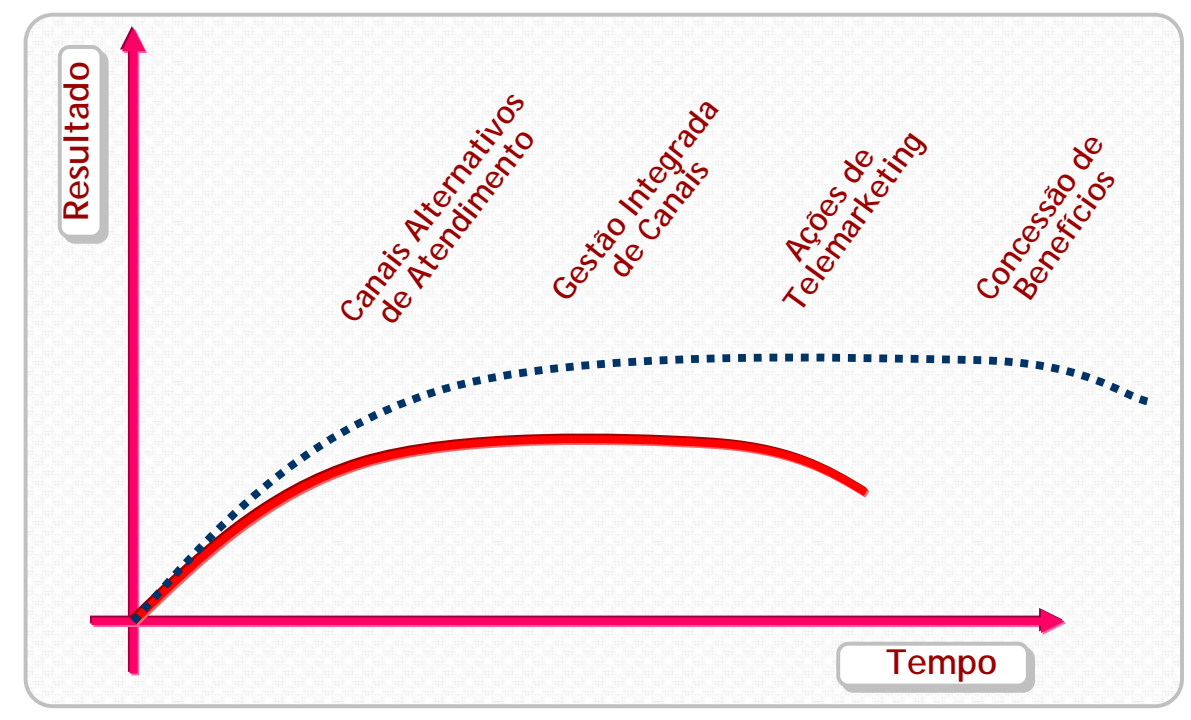

O exame das variáveis que compõem o database marketing que suporta as estratégias de CRM permite, através de tratamento estatístico aliado às interferências comportamentais, a identificação de indicadores e fatores que propiciam ou dificultam o consumo de determinados produtos para determinado perfil de cliente e o acompanhamento de seu estágio no ciclo de vida e sua natural ampliação, fato que enriquece o valor da ferramenta enquanto suporte à gestão do negócio.

É também a partir da análise do database marketing que se alcança um maior direcionamento e precisão das ações de marketing voltadas para nichos específicos de mercado, dos quais se permite conhecer perfis de consumo, reduzir custos com pesquisa em função do uso das informações disponíveis e desenvolver produtos e serviços diferenciados, tornando o mercado mais receptivo para as ações empreendidas, economizando-se tempo e recursos. 
Avaliando-se essa dinâmica voltada para os canais remotos de relacionamento, onde é minimizada a probabilidade de contato físico com o cliente, as ações estruturadas no CRM se revestem de maior importância, pois pretendem dotar a empresa com uma ferramenta que lhe permita tratar os clientes com um nível de conhecimento e especialização que busque suprir a falta do contato direto.

\subsubsection{Perspectiva Ampliada - Necessidades não financeiras - Market Place -}

\section{Comércio Eletrônico}

Alinhadas às ações de gestão integrada dos canais, suportadas pelas ações de CRM citadas, existem inúmeras oportunidades de aprimoramento do relacionamento com os clientes e potencialização dos resultados comerciais por meio da estruturação de ações de vendas cruzadas entre clientes de segmentos diferenciados e demais empresas ligadas da corporação.

A Figura 29 - Universo Virtual busca ilustrar a forma como as organizações podem potencializar os resultados demonstrando de maneira metafórica como aproveitar primeiramente as oportunidades internas significa "pescar dentro de seu aquário corporativo" as inúmeras necessidades de cada cliente e segmento, incrementando a quantidade de produtos e serviços disponíveis da organização para seus segmentos/empresas ligadas. 
Figura 29 - Universo Virtual

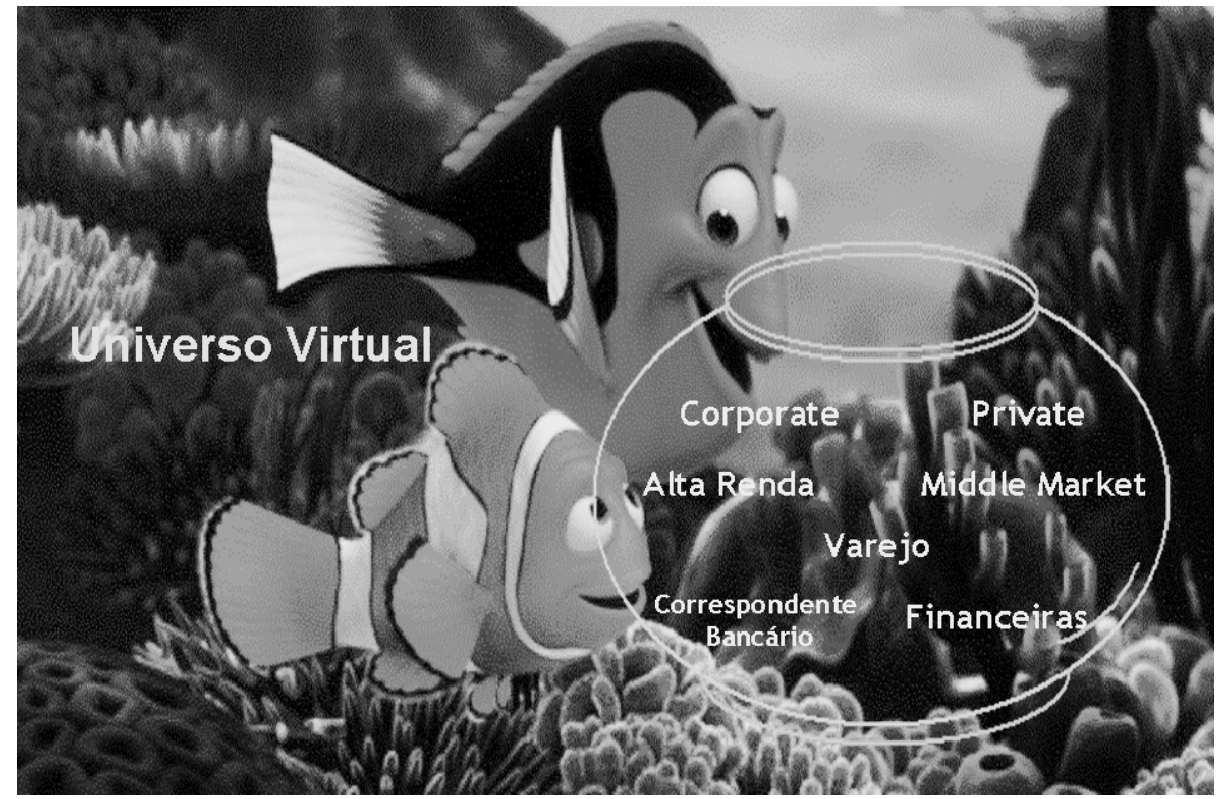

Porém, para se transformar essas oportunidades em ações efetivas é necessária uma total integração de inteligência de negócios de todas as áreas da empresa, o que não é trivial.

Nesse contexto, para os bancos potencializarem a oportunidade de utilização dos canais de relacionamento remotos, principalmente por meio da Internet, significa criar oportunidades de interação em um Universo Virtual praticamente ilimitado.

Os clientes não demandam exclusivamente produtos financeiros. Esse conceito expandido permite que sejam ampliadas as oportunidades de relacionamento para o universo $\mathrm{B} 2 \mathrm{~B}$ business to business, $\mathrm{B} 2 \mathrm{C}$ business to consumer e C2C consumer to consumer, criando um diferencial competitivo na medida em que se promove a aproximação das empresas e pessoas físicas, presentes no mesmo market place, cabendo ao banco facilitar esse relacionamento 
por conhecer as características financeiras de cada cliente e utilizar adequadamente o CRM para maximizar o potencial de sucesso dessa ação.

\subsection{Conclusões}

\subsubsection{Considerações Gerais}

\subsubsection{Mudança de Estratégia}

Fica evidenciado que num cenário de constantes mudanças, aliado às opções cada vez mais criativas e numerosas que os clientes tem à sua disposição num mercado que disputa de maneira acirrada a sua atenção, que as empresas em geral e mais particularmente os bancos, devem rever constantemente sua estratégia de atuação.

A Figura 30 - Revendo a Estratégia, demonstra claramente essa mudança de estratégia das empresas que dentre as várias modificações nas perspectivas de seu posicionamento perante o mercado, deixa evidenciado que o alvo de suas atenções e fator preponderante na determinação de sua estratégia é a mudança da visão de foco em produtos para o foco total nos clientes. 
Figura 30 - Revendo a Estratégia

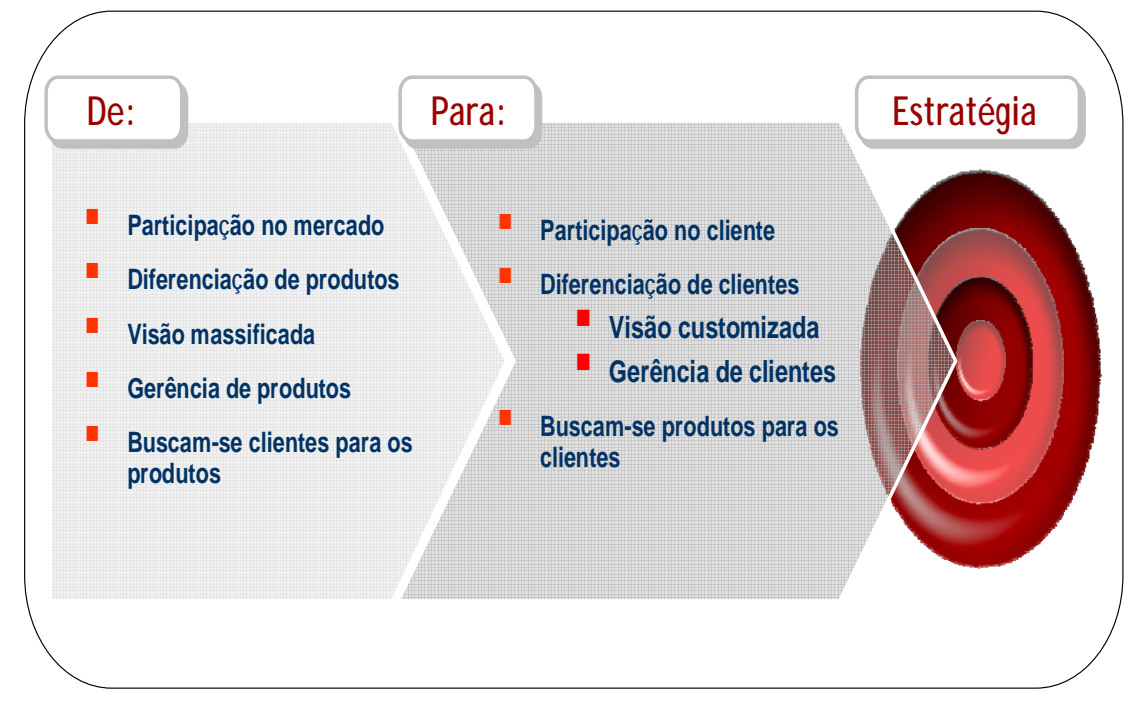

Toda a dinâmica de criação de valor para a empresa passa pelo crivo das necessidades dos clientes que determina a criação de novos produtos e as adaptações na formatação dos serviços agregados, visando despertar no consumidor a percepção de que existe exclusividade e diferenciação na oferta, tornando única sua experiência de consumo e determinando sua continuidade de relacionamento com a empresa.

\subsubsection{Gestão do Relacionamento com Clientes}

A Tecnologia produziu e segue produzindo efeitos sobre a indústria financeira, assim como sobre os seus clientes.

A evolução da tecnologia dotou a indústria financeira de varejo de um respeitável conjunto de ferramentas que lhe proporcionou a capacidade de tratar transações financeiras e procedimentos operacionais de forma mais rápida e eficaz. 
A conseqüência desse fenômeno tem sido a redução progressiva das atividades de apoio e retaguarda, tendo em vista seu crescente nível de automação, como também a disponibilização de um maior tempo para a realização de atividades de natureza comercial.

Para o cliente, um conjunto plural de serviços é constantemente ampliado, cuja utilização plena por vezes esbarra na percepção da real contribuição oferecida pelo novo serviço, como também na capacidade de adaptação do cliente a esse freqüente movimento de mudanças.

Não são poucas as vezes em que se desenvolvem serviços pouco aderentes às demandas reais, pelo fato de não terem sido as mesmas corretamente interpretadas, dando origem a crescentes gaps entre as evoluções da Tecnologia e do comportamento dos indivíduos.

A evolução tecnológica aliada à crescente tendência de automação de transações promoveu a oferta de diversos canais de serviços que se apresentaram como alternativas para o cliente da indústria financeira de varejo, dentre os quais destacam-se: o auto-atendimento, as centrais de atendimento telefônicas, a internet e o telefone celular.

$\mathrm{Na}$ medida em que a adesão aos canais alternativos se torna progressivamente mais observada, quer seja pela conveniência oferecida, quer seja pela preferência manifestada; as instituições financeiras passam a ter registros mais precisos e em maior volume, das transações e hábitos de uso de seus clientes. 
Novas técnicas foram desenvolvidas no sentido de se fazer uso desse rico banco de dados no qual estão contidos os registros das transações detalhadas e acumuladas da história do relacionamento do cliente com a instituição financeira.

À organização desses dados de maneira estruturada por assunto, histórico e demais atributos, denomina-se Data Warehouse. O desenvolvimento de soluções de arquivamento, manipulação e consulta desses dados permitiu a aplicação de sofisticadas técnicas estatísticas tendo como objeto principal a inferência sobre o comportamento do cliente, visando ampliar o conhecimento sobre o mesmo, apoiando a instituição em seu processo de tomada de decisões.

Nesse sentido, o Data Mining que conforme define Takaoka in Angelo \& Giangrande (1999, p.95) é "a extração não trivial, a partir de banco de dados, de informação útil, implícita e não conhecida previamente" procurar subsidiar a gestão do relacionamento com o cliente, denominado CRM Customer Relationship Management.

Nas relações de negócio o CRM Customer Relationship Management procura desenvolver ferramentas que tornem necessárias a intervenção humana apenas em aspectos progressivamente mais complexos e necessários à ampliação da duração do relacionamento com o cliente, otimizando o investimento em Recursos Humanos, conforme se observa na Figura 31 - Ações de CRM sobre o Relacionamento. 
Figura 31 - Ações de CRM sobre o Relacionamento

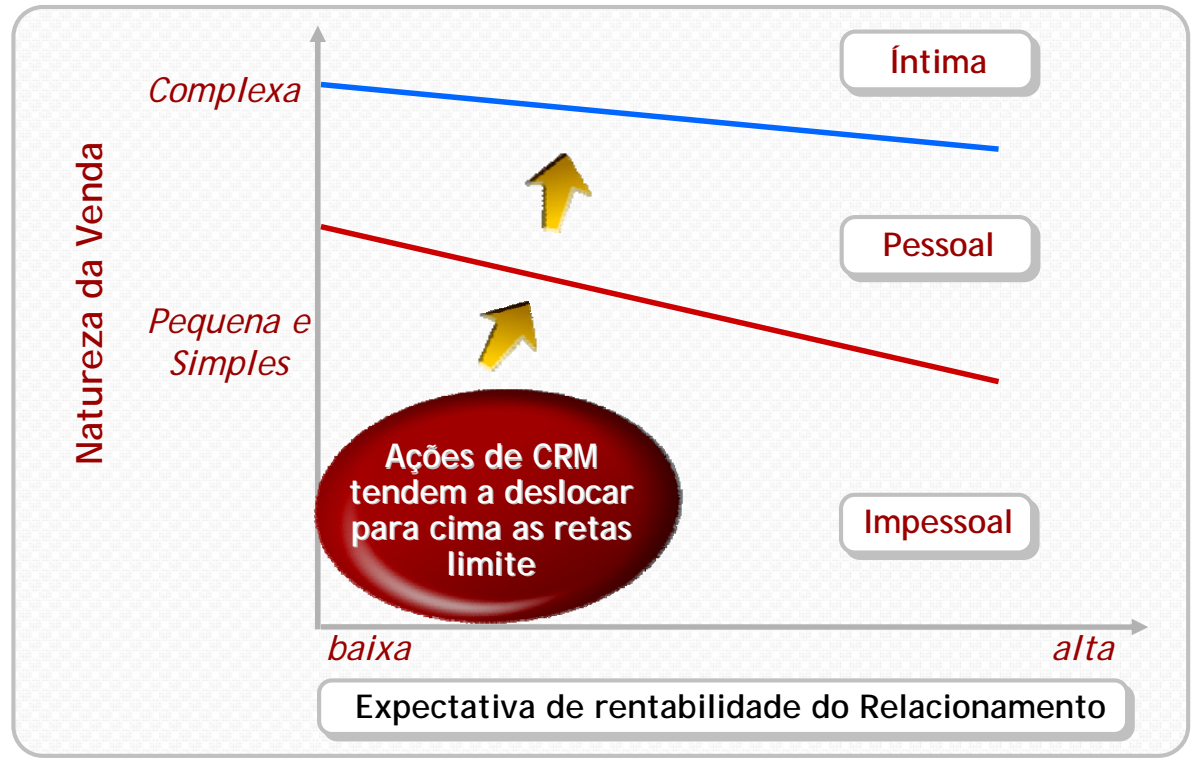

Fonte: Adaptado de The IT Journal - HP

As técnicas de Data Mining por vezes conduzem a resultados que, embora possam fazer sentido estatístico, carecem de maior conteúdo conceitual para serem mais profundamente interpretados.

Nesse contexto reside a potencial contribuição da Psicologia Social como apoio ao entendimento da dinâmica comportamental dos fenômenos observados.

\subsubsection{Tecnologia, Gerenciamento e Indivíduo.}

Palazzo (1993, p.35) estabelece uma relação de paralelismo entre o progresso experimentado pela tecnologia, pelo processo gerencial e pelo indivíduo no corrente século.

Observa o autor que a tecnologia apresentou uma evolução qualitativa significativamente mais expressiva do que a evolução das técnicas de 
gerenciamento que por sua vez também evoluiu mais do que os padrões de comportamento do indivíduo.

Como resultado dessas evoluções com gradientes diferenciados registram-se lacunas de natureza gerencial e humana provocando uma situação de descompasso entre as três variáveis em observação, conforme apresentado na Figura 32 Defasagem Tecnológica, Gerencial e Individual na Sociedade.

Figura 32 - Defasagem Tecnológica, Gerencial e Individual na Sociedade

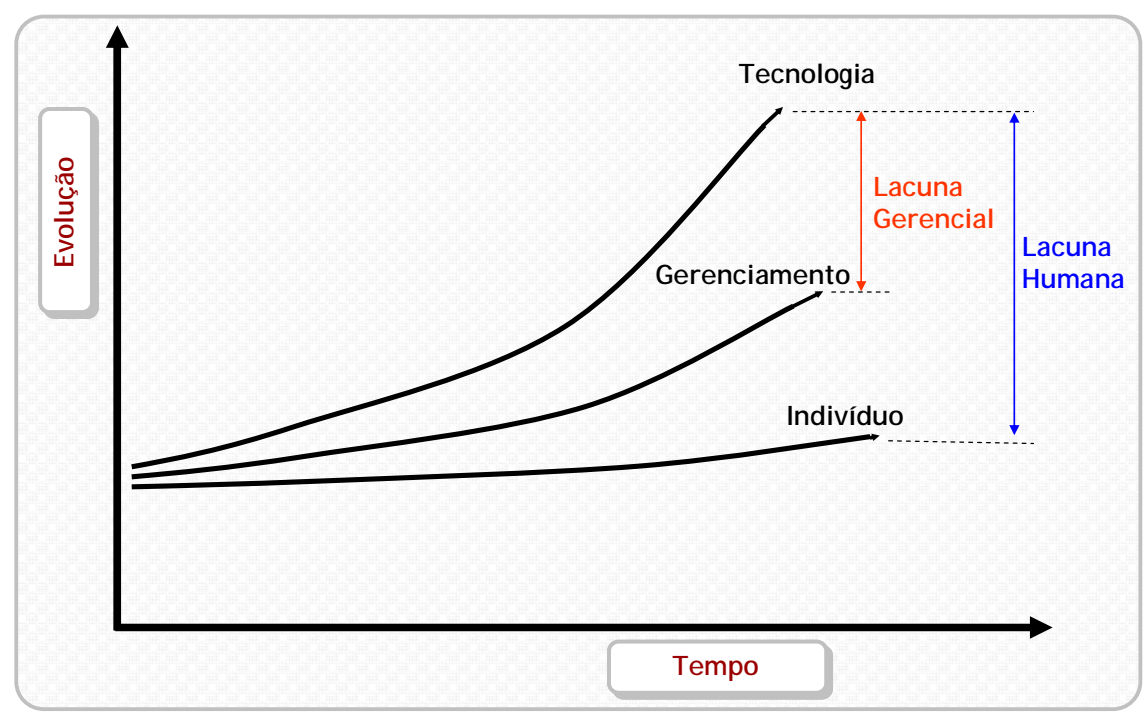

Fonte: Adaptado de Palazzo (1993 p.35)

Ainda que, qualitativamente, os padrões de comportamento do indivíduo apresentem uma variação pouco significativa quando contrastados com as demais variáveis, o aprofundamento de sua dinâmica reveste-se de substancial interesse por dotar o pesquisador de um ferramental capaz de interpretar e avaliar as ações mais apropriadas para se alcançar a melhor aderência entre as diferentes curvas de evolução traçadas. 
Nesse sentido a Psicologia e, em especial a Psicologia Social que se ocupa segundo Bock, Furtado e Teixeira (1999, p.126) da percepção social, da comunicação, das atitudes, do processo de socialização, dos grupos e papéis sociais, pode contribuir para o esclarecimento das questões relacionadas ao comportamento do indivíduo submetido ao processo de interação social cuja dinâmica se vê envolvida em variações distintas de padrões tecnológicos e gerenciais.

Beck \& Cowan apresentam o conceito de "Meme" buscando representar traços predominantes de culturas e estudar os seus estágios evolutivos refletindo suas características comuns de comportamento.

A análise dos atratores dos "Memes", entendidos como os ícones principais que os definem, contribui para a construção e interpretação do contexto psicossocial no qual se inserem os indivíduos, fornecendo parâmetros para o estudo da interação indivíduo-sociedade que é a disciplina da Psicologia Social.

\subsubsection{Inovação}

Gibson (1998) acrescenta que segundo Porter, "inovar significa oferecer coisas de um modo diferente, criar novas combinações. Inovação não significa pequenas melhorias incrementais - estas são apenas partes do modo de ser de uma organização dinâmica. Inovar é encontrar novas maneiras de combinar coisas em geral". 
Segundo Imai (1986), existem dois enfoques contrastantes do progresso: o enfoque gradual e o enfoque de grandes saltos. No primeiro há uma orientação para o aprimoramento contínuo, Kaizen enquanto que no segundo há uma orientação para a inovação. Os resultados das duas orientações ao longo do tempo podem ser assim representados, segundo as Figura 33 e Figura 34.

Figura 33 - Modelo de Aprimoramento contínuo: Qualidade - Continuidade

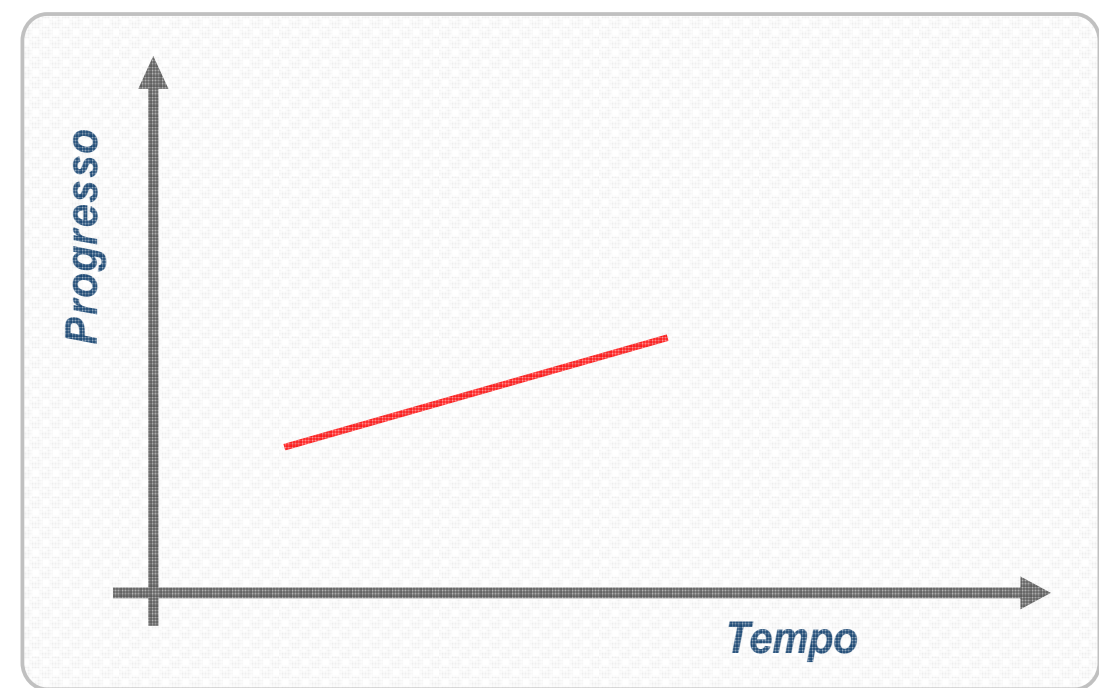

Fonte: Adaptado de Imai (1986)

Figura 34 - Modelo de Inovação: Inovação - Descontinuidade

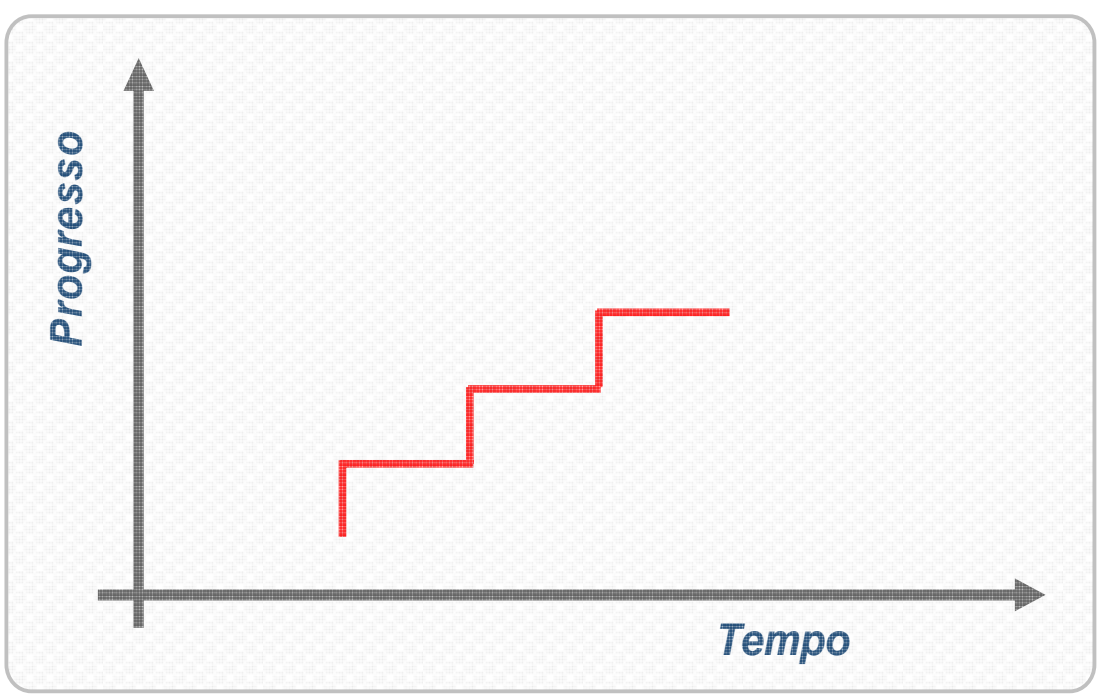

Fonte: Adaptado de Imai (1986) 
No enfoque voltado para inovação observa-se um regime de descontínuo progresso, motivado pelos "saltos" associados a inovações cujos reflexos se manifestam de maneira abrupta em razão da magnitude da mudança que os mesmos inserem, ao passo que no enfoque voltado ao aprimoramento contínuo o ritmo de evolução é gradual e tem manifestação descrita como uma curva contínua e crescente. Deve-se ressaltar que a configuração de uma curva contínua e crescente é uma aproximação do que de fato se verifica como produto do aprimoramento que é uma seqüência de "pequenos saltos" na direção do progresso.

Em matéria publicada na Revista Veja (2007), foi atribuído especial destaque para uma reportagem sobre o Vale do Silício nos Estados Unidos, intitulada de "Inovar ou morrer é a lei nesse vale".

O Vale do Silício fica localizado na Califórnia tendo como combustível principal os recursos da Universidade de Stanford, o Vale do Silício é uma vitrine da economia americana.

$\mathrm{Na}$ matéria (op.cit.) foi mencionado que "Nos anos 90, pequenos empreendimentos - muitos deles criados em garagens por estudantes universitários - tornaram-se negócios milionários da noite para o dia. Quando a bolha estourou em 1999, apenas uma em cada 4000 empresas sobreviveu, metade dos empregos se extinguiu e os investimentos secaram. Do setor de internet, a crise se disseminou em cascata. Só recentemente o rumo do crescimento foi reencontrado. 2005 foi o primeiro ano desde o fim da bolha em que a geração de empregos superou o volume de demissões. Um novo ciclo de prosperidade está em curso". 
A matéria (op.cit) destaca ainda que "nesse contexto, estão instaladas empresas como Google, IBM, Oracle, indústrias de bio e nanotecnologia, tendo também, sido a base para o nascimento do site revolucionário de vídeos You Tube, até a sua explosão de sucesso tendo sido adquirido pelo Google. A Apple de Steve Jobs também figura desse cenário. A empresa revolucionou o conceito do consumo de músicas na Internet em sua loja virtual iTunes para serem ouvidas, obviamente, em seu mundialmente cobiçado aparelho iPod. Jobs também é o criador da Pixar, estúdio de animações que revolucionou o conceito de filmes de animação com produções como Toy Story".

Mas a última de suas marcas inovadoras fica por conta da criação de uma das ferramentas de maior relevância no conceito de convergência e mobilidade da atualidade. A criação do iPhone, o novo telefone celular da Apple que dentre as inúmeras funcionalidades possui acesso à internet e toca música digital é uma verdadeira aula de inovação.

A matéria da Revista Veja (2006) destaca ainda que "a criação do aparelho produziu 200 novas patentes para a empresa. Isso é o dobro do que o Brasil registra em um ano. O iPhone reinventa a relação homem-máquina, pois o aparelho não tem teclas sendo que os dedos comandam as operações ao encostar ou apenas deslizar sobre uma tela de 3,5 polegadas sensível ao toque".

Outro destaque mencionado na matéria da Revista Veja (2006) registra que "no Google, seus fundadores Larry Page e Sergey Brin, que também deram seus primeiros passos no negócio quando ainda eram estudantes em Stanford, afirmam 
que o segredo da empresa para manter-se sempre à frente com projetos inovadores é o verdadeiro exército de Ph.D.s. que compõe o quadro de funcionários da empresa, atualmente com 10.000 funcionários. - 'Quando contratamos alguém não queremos só os melhores: queremos os mais brilhantes', - diz Marissa Mayer, profissional que gerencia a área criativa do Google".

A conclusão descrita na matéria (op.cit) afirma que "embora sejam distintas no porte e no ramo de atividade, essas empresas comungam um traço cultural que parece estar no DNA do lugar: a busca incessante da inovação".

Inovação ultrapassa novas tecnologias e novos processos, abarcando novas formas de organização, novos negócios conjuntos, novas fábricas e escritórios, sistemas diferenciados de relações industriais e formulação de novas missões.

Uma empresa inovadora é aquela que reconhece o poder resultante da combinação sinérgica decorrente da contribuição do aprimoramento contínuo como esforço em direção ao atendimento das expectativas do cliente, aliado ao incentivo à criatividade e expansão do espectro da visão de negócios, capaz de produzir "saltos" no valor que a empresa tem a proporcionar ao seu mercado, conforme ilustrado na Figura 35 - Qualidade - Inovação. 
Figura 35 - Qualidade - Inovação

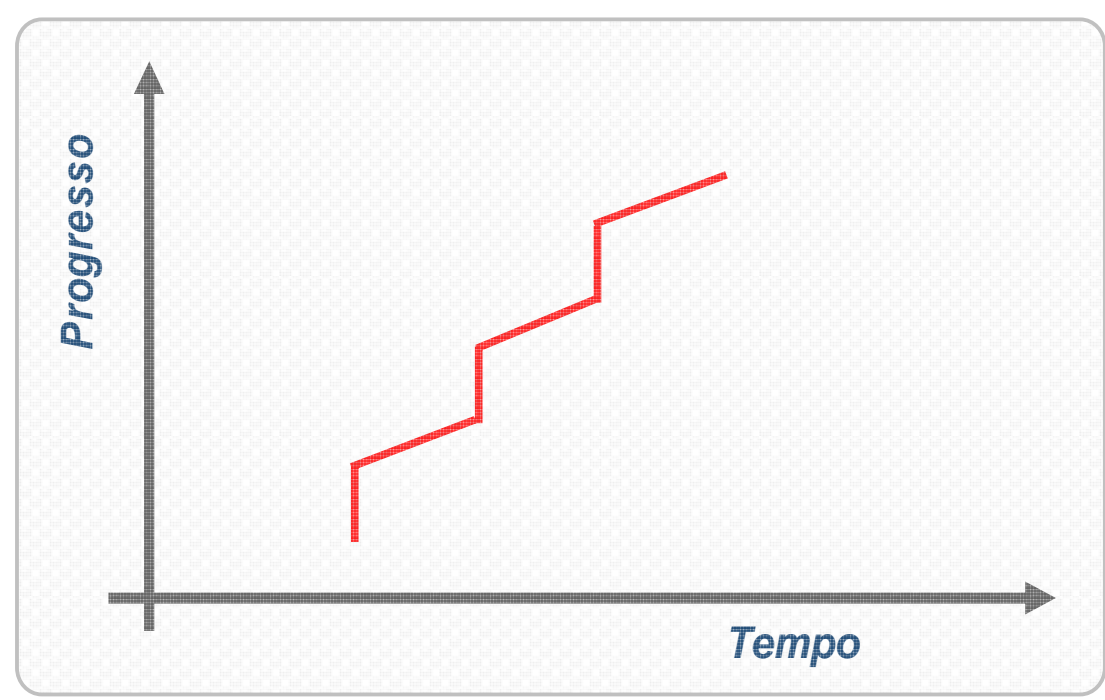

Fonte: Adaptado de Imai (1986)

A inovação é requisito na preparação da empresa que deseja competir para o futuro. De acordo com os questionamentos propostos por Hamel e Prahalad (1994), quando se pretende diagnosticar a situação da empresa que busca se posicionar em relação ao futuro, ao responder se:

- É seguidora de regras ou é formadora de regras?

- É preponderantemente orientada para o curto prazo?

- Busca de maneira inconsistente, as iniciativas de qualidade e reengenharia?

- Está mais preocupada em preservar o passado do que inventar o futuro?

A resposta às questões propostas conduz ao exercício da reflexão sobre a verdadeira condição da empresa, sua orientação com relação ao futuro e, por fim, sua posição na escala evolutiva: eficiência $=>$ qualidade $=>$ flexibilidade $=>$ inovação. 


\subsubsection{Considerações Finais}

\subsubsection{Interpretando o Novo Paradigma da Distribuição Bancária, frente ao comportamento Humano.}

No novo paradigma de distribuição bancária, resultante do avanço tecnológico, desintermediação e desregulamentação financeira e das novas demandas dos clientes, a mudança no comportamento dos mesmos definirá a dinâmica de relacionamento cliente-banco nos próximos anos.

No ambiente dos bancos, a adequada combinação dos canais preferenciais de relacionamento remoto, representados pela Internet, Auto-Atendimento, Call Center e Mobile Banking e otimizados pelas dimensões de transação e relacionamento, será o meio propulsor da convergência, suportada por uma plataforma multicanal que permita que o atendimento aos clientes possa culminar em uma experiência única de relacionamento integrado e completo, conjugando os fatores conveniência, facilidade de uso e segurança.

Para os clientes, o frenético avanço tecnológico trará a cada dia novos atores para integrar esse cenário, representados pelos inúmeros dispositivos eletrônicos como laptops, palmtops, smartphones, e principalmente os telefones celulares, que farão o papel de interlocutores de toda essa interatividade, com total mobilidade.

Fica evidenciado que as comunidades consumidoras do futuro, representadas hoje pelas crianças e jovens, terão à sua disposição um arsenal tecnológico que irá 
fomentar ainda mais os meios de relacionamento remotos, pois já nasceram em um mundo com Internet banda larga.

A convergência e a mobilidade deverão concentrar progressivamente o fluxo de transações dos canais eletrônicos, com o atributo diferencial de se tratar de um fluxo pré-identificado, interconectando os agentes da cadeia, de modo a reduzir seus elos e aproveitando toda a oportunidade do CRM para maximizar o potencial de relacionamento no processo de oferta e demanda de produtos financeiros.

Diante dessas evidências, a vantagem competitiva dos bancos será a adequada capacidade de administração do fluxo pré-identificado de clientes, norteando as ações dos bancos no sentido de se antecipar às necessidades de cada público ou nicho específico, possibilitando oferecer o diferencial necessário para atrair, fidelizar e desenvolver os relacionamentos comerciais com os clientes da forma mais duradoura possível.

Surge nesse contexto, mais um grande desafio a ser superado, tendo em vista que as influências sobre o comportamento dos indivíduos, motivadoras e resultantes da revisão da logística de distribuição bancária, culminarão numa demanda cada vez mais ampla e diversificada de produtos e serviços, tornando ainda mais difícil atuar de forma pró-ativa, em um cenário de mudanças, cujas expectativas serão cada vez maiores, em um espaço menor de tempo e ocorrendo em âmbito global. 
Esse desafio motiva o desenvolvimento do presente estudo que busca evidenciar a associação do comportamento financeiro dos clientes com seu tipo psicológico, inserindo novas variáveis e propiciando o aperfeiçoamento dos modelos de gestão do relacionamento com clientes, contribuindo para aprimorar a assertividade na identificação da melhor forma de atender a demanda e antecipar-se às necessidades dos clientes pré-identificados, cujo fluxo representa de forma majoritária o canal preferencial de contato cliente-banco. 


\section{TIPOS PSICOLÓGICOS}

\subsection{Conceito}

Conforme cita Zacharias (2006, p.54) "Segundo a concepção de Jung, tipo é uma disposição geral que se observa nos indivíduos, caracterizando-os quanto a interesses, preferências e habilidades. Jung afirma que a tipologia não tem a finalidade de dividir as pessoas, mas é um instrumento de investigação crítica, na medida em que oferece uma ordenação metódica de conteúdos psíquicos".

A descrição dos tipos psicológicos compreende uma combinação de atitudes - introversão e extroversão -, funções - intuição e sensação, pensamento e sentimento - e dimensões - julgamento e percepção - do comportamento do ser humano.

As atitudes, introversão e extroversão, representam a forma como o indivíduo direciona preferencialmente sua atenção. De acordo com Zacharias (2006, p.55) "Ambos são tão diferentes que podem ser identificados até pelos leigos. Aliás, essa diferença é percebida logo cedo no comportamento infantil. Todos nós já observamos pessoas impenetráveis que resistem aos contatos sociais, bem como aquelas que se relacionam com todos".

Myers e McCaulley (1992, p.2) complementam o conceito ao explicar que "Extraverts are oriented primarily toward the outer world; thus they tend to focus their perception and judgement on people and objects. Introverts are oriented primarily 
toward the inner world; thus they tend to focus their perception and judgement upon concepts and ideas".

Conforme prossegue Zacharias (2006, p.55) em sua explicação, "Se uma pessoa é extrovertida isso não quer dizer que ela vai se comportar de modo extrovertido em todos os lugares e sempre. É possível observar em um único indivíduo a presença de ambas as disposições. O que define o tipo é a prevalência da disposição".

As funções são divididas em dois grupos: intuição e sensação, pensamento e sentimento.

O primeiro grupo - intuição e sensação - conhecido como funções de input, refere-se à maneira preferencial do indivíduo para receber, processar, transformar e metabolizar as informações.

Jung classifica as funções de input como funções irracionais. Não se trata de como a função é julgada, mas sim como ela é recebida e organizada pelo indivíduo.

A sensação diz respeito à percepção de fatos que chegam aos indivíduos por intermédio dos cinco sentidos.

Segundo Reis (1984, p.157), "A sensação constata a presença dos objetos que nos cercam e, através de nossos sentidos, informa sobre suas características. Já a intuição é percepção via inconsciente. Cada coisa que percebemos tem uma 
história. Seu passado e seu futuro estão contidos, de algum modo, em algumas características presentes no momento da observação Estas características são captadas pela intuição; é a função que nos informa sobre de onde vêm os objetos e qual o possível curso de seu desenvolvimento. Geralmente nos chega sob a forma de pressentimentos, palpites ou inspirações".

Assim sendo, a exemplo das atitudes introversão - extroversão, as funções intuição - sensação também formam um par de opostos.

O segundo grupo de funções - pensamento e sentimento - conhecido como funções de output, diz respeito à maneira pela qual ocorre o processo de tomada de decisão.

Uma vez recebida acumulada e armazenada a informação, os indivíduos agem segundo um dos padrões de julgamento e tomada de decisão dessa função, denominada por Jung como função racional.

Reis (1984, p.156) afirma que "O pensamento é a função que esclarece o que são os objetos. Julga, classifica, discrimina uma coisa da outra. O pensamento, para avaliar os objetos, deve se basear em critérios impessoais, lógicos e objetivos. Para tal, é necessário excluir o valor afetivo que o objeto possa ter para a pessoa; se a atrai ou não, o que é domínio do sentimento. É através do sentimento, então, que o sujeito faz uma estimativa sobre o objeto, também um julgamento, porém que funciona com outra lógica, a lógica do coração". 
Myers e McCaulley (1992, p.2) acrescentam que "The Thinking-Feeling index is designed to reflect a person's preference between two contrasting ways of judgement. A person may rely on thinking $(T)$ to decide impersonally on the basis of logical consequences, or a person may rely primarily on feeling $(F)$ to decide primarily on the basis of personal or social values".

Dessa forma a função racional - pensamento e sentimento - também forma um par de opostos.

As dimensões - julgamento e percepção - representam as duas formas como os indivíduos lidam com o mundo exterior.

Myers e McCaulley (1992, p.2) observam que "The Judgement-Perception index is designed to describe the process a person uses primarily in dealing with the outer world, that is, with the extraverted part of life. A person who prefers judgement (J) has reported a preference for using a judgement process (either thinking or feeling) for dealing with the outer world. A person who prefers perception $(P)$ has reported a preference for using a perceptive process (either $S$ or $N$ ) for dealing with the outer world".

Procura-se estabelecer a seguir um quadro de referência das oito preferências apresentadas em suas quatro dimensões de agrupamento:

E - Extrovertido - Atenção ao externo / coisas

I - Introvertido - Atenção ao interno / idéias 


$$
\begin{aligned}
& \text { S - Sensação - Presente / informação } \\
& \text { N - Intuição - Futuro / possibilidade } \\
& \text { T - Pensamento - Decisão lógica } \\
& \text { F - Sentimento - Decisão por valores } \\
& \text { J - Julgamento - Abordagem planejada } \\
& \text { P - Percepção - Abordagem flexível }
\end{aligned}
$$

Dessa maneira o conjunto de variáveis que dão forma aos tipos psicológicos está composto em 16 grandes grupos, resultantes da combinação das atitudes introversão e extroversão -, funções irracionais - sensação e intuição -, funções racionais - pensamento e sentimento - e as dimensões com as quais lidamos com o mundo exterior - julgamento e percepção.

Nesse trabalho foi aplicado o teste Keirsey Temperament Sorter disponível na internet no site www.keirsey.com com o propósito de se apurar o tipo psicológico do grupo a ser estudado, conforme descrito no capítulo referente à metodologia.

O resultado do teste é apresentado em escalas, cujos significados são resumidos no Quadro 3 - Escalas medidas pelo teste Keirsey Temperament Sorter no Quadro 4 - Características das escalas.apresentadas a seguir: 
Quadro 3 - Escalas medidas pelo teste Keirsey Temperament Sorter

\begin{tabular}{|c|c|c|}
\hline Escala & Refere-se a & Atividade-chave \\
\hline $\begin{array}{c}\text { Extroversão- } \\
\text { Introversão }\end{array}$ & Como uma pessoa é motivada & Motivação \\
\hline $\begin{array}{c}\text { Sensação-Intuição } \\
\text { Pensamento- } \\
\text { Sentimento }\end{array}$ & $\begin{array}{c}\text { Naquilo que a pessoa presta } \\
\text { atenção }\end{array}$ & Observação \\
\hline $\begin{array}{c}\text { Julgamento- } \\
\text { Percepção }\end{array}$ & $\begin{array}{c}\text { Tipo de vida que uma pesso toma } \\
\text { adota }\end{array}$ & Decisões \\
\hline
\end{tabular}

Quadro 4 - Características das escalas

\begin{tabular}{|c|c|c|}
\hline \multirow[b]{2}{*}{ Motivação } & Extroversão & Introversão \\
\hline & $\begin{array}{l}\text { Preferência por tirar energia } \\
\text { do mundo exterior das } \\
\text { pessoas, atividades ou coisas }\end{array}$ & $\begin{array}{c}\text { Preferência por tirar energia } \\
\text { do mundo interior das idéias, } \\
\text { emoções ou impressões } \\
\text { pessoais }\end{array}$ \\
\hline \multirow[b]{2}{*}{ Observação } & Sensação & Intuição \\
\hline & $\begin{array}{c}\text { Preferência por obter } \\
\text { informações através dos cinco } \\
\text { sentidos e observar aquilo que } \\
\text { é real }\end{array}$ & $\begin{array}{c}\text { Preferência por obter } \\
\text { informações através do "sexto } \\
\text { sentido", observando o que } \\
\text { pode ser }\end{array}$ \\
\hline \multirow[b]{2}{*}{ Decisões } & Pensamento & Sentimento \\
\hline & $\begin{array}{l}\text { Preferência por organizar e } \\
\text { estruturar as informações para } \\
\text { tomar decisões de maneira } \\
\text { lógica e objetiva }\end{array}$ & $\begin{array}{l}\text { Preferência por organizar e } \\
\text { estruturar as informações para } \\
\text { tomar decisões de maneira } \\
\text { pessoal e orientada para os } \\
\text { valores }\end{array}$ \\
\hline \multirow{2}{*}{ Modo de vida } & Julgamento & Percepção \\
\hline & $\begin{array}{l}\text { Preferência por ter uma vida } \\
\text { organizada e planejada }\end{array}$ & $\begin{array}{l}\text { Preferência por ter uma vida } \\
\text { espontânea e flexível }\end{array}$ \\
\hline
\end{tabular}

Keirsey (1998, p.20) afirma que "There are two sides to personality, one of which is temperament and the other character" e conceitua temperamento e caráter da seguinte forma: "Temperament is a configuration of inclinations, while character is a configuration of habits. Character is disposition, temperament pre-disposition. Thus, for example, foxes are predisposed - born - to raid hen houses, beavers to dam up streams, dolphins to affiliate in close-knit schools, and owls to hunt alone in 
the dark. Each type of creatue, unless arrested in its maturation by an unfavorable environment, develops the habit appropriate to its temperament: stealing chickens, building dams, nurturing companions, or hunting at night".

Keirsey (1998, p.20) estabelece um paralelo com o cérebro humano ao efetuar a seguinte comparação "our brain is a sort of computer which has temperament for its hardware and character for its software. The hardware is the physical base from which character emerges, placing an identifiable fingerprint on each individual's attitudes and actions. His underlying consistency can be observed from a very early age - some features earlier than the others - long before individual experience or social context (one's particular software) has had time or occasion to imprint the person. Thus temperament is the inborn form of human nature; character, the emergent form, which develops through the interaction of temperament and environment".

Zacharias (2006, p.76), ao analisar o conceito de temperamento proposto por Keirsey e Bates, relata que "os tipos junguianos emergiriam dos temperamentos da diferenciação, e não da combinação entre as funções. O desenvolvimento se daria pela individuação ou separação e não pela integração, associação ou concatenação". E, acrescenta, citando Keirsey e Bates que "Um indivíduo se torna de um determinado tipo a partir de um determinado temperamento e não porque uma atitude de alguma forma se combinou com uma função". 
Assim, os temperamentos resultariam da combinação entre Sensação (S) Intuição (N) e Pensamento (T) e Sentimento (F), produzindo quatro agrupamentos distintos.

Keirsey (1998, p.20) enfatiza que "temperament, character and personality are configured, which means that, not only are we predisposed to develop certain attitudes and not others, certain actions and not others, but that these actions and attitudes are unified - they hang together".

E Keirsey (1998, p.20) prossegue apresentando as quatro combinações resultantes de temperamento: "Thus, the SPs base their self-image on artistic action, audacity, and adaptability to circumstance, these three traits evolving together of necessity. Furthermore, these three traits, developing together as if out of a single seed, preclude the emergence of a self-image based on, say, empathy, benevolence, and authenticity, which are characteristics of the NFs. In the same way, the SJs base their self-image on reliability, service, and respectability, these three traits emerging together as a unified structure of personality. And again, the unfolding of these three traits weighs against developing a self-image based on ingenuity, autonomy, and willpower, which is characteristic of the NTs".

Nagelschmidt apud Zacharias (2006, p.78), observa que "a chave para o entendimento do conceito de temperamento formulado por Keirsey e Bates estaria na importância dada pelos autores à diferença entre Sensação e Intuição, pois para eles a identificação das diferenças na forma como as pessoas coletam informações permitiria a compreensão da maior parte das interações humanas. Portanto, o 
temperamento seria definido a partir da preferência pela Sensação (S) ou pela Intuição (N)".

Zacharias (2006, p.78) prossegue na descrição dos temperamentos SJ e SP, definidos por Keirsey como sendo respectivamente, Guardians e Artisans, e acrescenta que "A preferência pela Sensação como método de coleta de informação significa a preferência por informações concretas, que possam ser vistas, cheiradas ou tocadas. De acordo com Keirsey e Bates (1978), para indivíduos que preferem as informações concretas é importante saber o que fazer com os dados que recebem: organizá-los metodicamente (preferência pelo modo Julgamento de relacionar-se com o mundo). Portanto, para os indivíduos tipo Sensação, os temperamentos possíveis seriam o Realista Judicativo (SJ) ou o Realista Perceptivo (SP) (SILVA, 1992)".

Farrell (2003, p.60) propõe uma denominação distinta para os quatro grupos, segundo sua ótica de seu estudo ao afirmar que "Keirsey calls them Artisans, Rationals, Idealists, and Guardians. We refer to them as Freelance Creators, Systems Masterminds, Pathfinders, and Guardians of Establishment to reflect the way each defines wealth and getting rich in the Millionaire's Code".

Linder (2002, p.122-125) apresenta uma relação entre Temperament and Money e propõe a seguinte classificação para os grupos:

"Here is a summary of the four primary temperaments, focusing on their implications for our financial decisions". 
Para os Guardians é elaborado o seguinte conceito:

\section{"Protectors (SJ): Most Responsible}

For protectors, the good life is preserving a comfortable, secure, and organized home and work environment. Their behaviors show protectors to be economical, structured, conservative, and cautious, with an orientation on the past".

Os Artisans são apresentados como:

\section{"Players (SP): Most Free-Spirited}

For players, the good life is having the freedom to do what feels good and make an impression. Their behaviors show players to be spontaneous, impulsive, risk-taking, and present-oriented".

Os Idealists são comparados a:

\section{"Pleasers (NF): Most Empathetic}

For pleasers, the good life is cultivating relationships, growing personally, and helping others achieve their potential. Their behaviors show pleasers to be focused on relationships and personal involvement, with an orientation on the future".

O último grupo de temperamentos, os Rationals, é classificado por Linder como: 
For planners, the good life is challenging one's self to acquire expertise and pursue excellence. Their behaviors show planners to be problem solving, pursuing excellence, and skeptical, with a future/infinite orientation".

Os 16 tipos psicológicos, resultantes das combinações dos quatro binômios de preferências: Extroversão (E) - Introversão (I); Sensação (S) - Intuição (N); Pensamento (T) - Sentimento (F) e Julgamento (J) - Percepção $(P)$, são a seguir descritos, sendo os mesmos agrupados em seus quatro tipos de temperamento: Artisans, Guardians, Idealists e Rationals.

\section{2 $\underline{\text { Artisans }}$}

Inicialmente são descritos os tipos psicológicos que compõem o temperamento dos Artisans, ou seja: The Promoter, The Crafter, The Performer e The Composer.

\subsubsection{The Promoter (ESTP)}

Segundo Zacharias (2006, p.174-175), esse tipo é denominado Sensação extrovertida com pensamento auxiliar, sendo que:

"Essas pessoas demonstram uma curiosidade ativa em relação a objetos, paisagens, pessoas, comida ou qualquer novidade apresentada a seus sentidos. Sua grande habilidade em usar os sentidos pode manifestar-se:

a) pela capacidade sempre presente de avaliar o que precisa ser feito em um momento qualquer e que se expressa em movimentos fáceis e graciosos; 
b) pela capacidade de absorver, utilizar e lembrar de um grande número de fatos;

c) por um gosto artístico apurado;

d) por um manejo habilidoso de ferramentas e matérias-primas".

Keirsey (1998, p.63) complementa a conceituação desse grupo ao afirmar que "Promoting is the art of putting forward an enterprise and then winning others to your side, persuading them have confidence in you and to go along with what you purpose. Of all the Artisans, ESTPs seem especially able to advertise or publicize their endeavors in this way, and to maneuver others in the direction they want them to".

Keirsey (1998, p.65) cita como exemplos desse tipo "some of America's most charismatic political leaders, including Andrew Jackson, Teddy Roosevelt, Franklin Roosevelt, John Kennedy, and Lyndon Johnson".

Keirsey (1998, p.66) resume assim os ESTPs "Charming, confident, popular, these tough, outgoing Artisans carry on amusing repartee with friends and colleagues, the laughter surrounding them as they recount from their endless supply of quips, anecdotes, and jokes. At the same time, these smooth Operators are usually something of a mystery to others. While they live in the moment and lend excitement - and unpredictability - to all their relationships, they rarely let anyone get really close to them". 


\subsubsection{The Crafter (ISTP)}

De acordo com Keirsey (1998, p.66), "The nature of the ISTPs is most clearly seen in their masterful operation of tools, equipments, machines, and instruments of all kinds. From microscopic drill to supersonic jet, from tiny scalpel to giant crane, a tool is any piece of equipment that extends or varies human powers - vehicles, lifters, cutters, and weapons are just four of the many categories of the tools that surround us".

Conhecidos como Pensamento introvertido com sensação auxiliar, os ISTPs, segundo Zacharias (2006, p.190), "usam o pensamento para buscar os princípios em que estão baseadas as informações que Ihes chegam à consciência. Estão habituadas a confiar no pensamento geralmente são lógicas, analíticas, capazes de críticas objetivas, só se deixando influenciar por argumentos que sejam racionais e solidamente fundamentados em fatos estabelecidos".

Myers e McCaulley (1992, p.20) complementam que os ISTPs são "Cool onlookers - quiet, reserved, observing and analyzing life with detached curiosity, and unexpected flashes of original humor. Usually interested in cause and effect, how and why mechanical things work, and organizing facts using logical principles".

Keirsey $(1998$, p.67) contrapõe que "Strangely, however, Crafters are not bored while doing their thing, even though there may be long stretches when nothing happens, as during travel, surfing, hunting, or fishing". 


\subsubsection{The Performer (ESFP)}

Myers e McCaulley (1992, p.20) explicam que os ESFPs são "Outgoing, easygoing, accepting, friendly, enjoy everything and make things more fun for others by their enjoyment. Like sports and making things happen. Know what's going on and join in eagerly. Find remembering facts easy than mastering theories. Are best in situations that need sound common sense and practical ability with people as well as with things".

Zacharias (2006,p.170) acrescenta que os ESFPs, Sensação extrovertida com pensamento auxiliar, "mostram uma curiosidade ativa a respeito de novos objetos, novas paisagens, novas atitudes, tipos de comida exóticas e diferentes, pessoas novas - em resumo, qualquer coisa nova apresentada a seus cinco sentidos. Essa grande habilidade para explorar e utilizar o sensório pode se manifestar por:

a) estarem sempre prontas e capazes de saber que tipo de ação um determinado momento exige e executá-la com precisão e elegância;

b) serem hábeis no manejo de pessoas e conflitos;

c) terem a capacidade de absorver, aplicar e recordar-se de um grande número de fatos;

d) terem um gosto artístico apurado.

Suas decisões são tomadas com base em valores pessoais (característica do sentimento) em vez da análise lógica do pensamento". 
Keirsey (1998, p.71) complementa aspectos da natureza do comportamento financeiro dos Performers ao afirmar que "They love to spend money on fun things (like clothes, jewelry, sports cars, vacation trips, and so on), and they will impulsively use up their credit card limits, and more, without giving much thought to family necessities".

\subsubsection{The Composer (ISFP)}

Keirsey (1988, p.71-72) esclarece que "Although ISFPs excel in what are called the fine arts, composing must not be thought of as only writing music, but as bringing into synthesis any aspect of the world of the senses. More than the other Artisans, Composers have a sure grasp of what fits and what doesn't fit in any and all kinds of artistic works, and so when an especially gifted painter, sculptor, choreographer, film director, song writer, playwright, poet, novelist, chef, decorator, or fashion designer shows up, he or she is likely an ISFP".

Zacharias (2006, p.186) observa que os ISFPs, Sentimento introvertido com sensação auxiliar, "tem sua atenção voltada principalmente para a realidade que aprende por meio de seus órgãos dos sentidos, realidade esta que tanto pode ser interior quanto exterior".

E acrescenta que "Embora sejam pessoas que se prendam a valores com grande intensidade, são facilmente influenciáveis por aqueles de quem gostam. Suas existências são governadas por lealdades e ideais internos sobre os quais não tem muita facilidade de falar. Os indivíduos que se enquadram nesse tipo psicológico 
expressam muito raramente suas emoções mais profundas e escondem-se atrás de uma máscara de tranqüila reserva, um núcleo interior muito suave e doce. Na sua vida cotidiana demonstram tolerância, flexibilidade, adaptabilidade e espírito aberto".

\subsubsection{Exemplos de Representantes dos Artisans}

No Quadro 5 - Artisans são exemplificados representantes do temperamento Artisans, segundo Keirsey.

Quadro 5 - Artisans

\begin{tabular}{|c|c|c|}
\hline \multicolumn{2}{|c|}{ ENTERTAINERS } & \multicolumn{2}{c|}{ OPERATORS } \\
\hline & & \\
\hline
\end{tabular}

\subsection{Guardians}

Os tipos psicológicos que compõem o agrupamento do temperamento Guardians, ou seja, The Supervisor, The Inspector, The Provider e The Protector encontram-se descritos a seguir. 


\subsubsection{The Supervisor (ESTJ)}

Zacharias (2006, p.172) afirma que os ESTJs, Pensamento extrovertido com sensação auxiliar, "acreditam que o comportamento dos indivíduos deveria basearse na lógica e aplicam isso a seu próprio comportamento: elas possuem um conjunto de regras bem definidas que irá regular seus postulados básicos sobre a vida e sobre o mundo; qualquer mudança em seu comportamento tem de ser precedida por uma mudança deliberada nesse conjunto de regras.

As pessoas que relatam esse perfil de preferências estão geralmente mais interessadas em perceber e apreciar a realidade presente no aqui-e-agora do que em possibilidades futuras, o que as torna mais sensatas, com os pés firmemente plantados no chão, práticas e realistas".

O autor (2006, p.173) complementa que "Esse tipo psicológico geralmente precisa fazer um esforço para valorizar o sentimento. Como tende a confiar cegamente em sua maneira lógica e racional de encarar os problemas, corre o risco de passar com freqüência por cima de valores sentimentais, não levando em consideração aquilo que é pessoalmente importante para elas e para as outras pessoas".

Keirsey (1998, p.105) enfatiza que "Like all the guardians, Supervisors worry a good deal about society falling apart, morality decaying, standards being undermined, traditions being lost, and so on, and they do all they can to preserve and to extend the institution that embody social order. These Guardians are so in tune 
with the established, time-honored institutions that they have a hard time understanding those who might wish to abandon or radically change them".

\subsubsection{The Inspector (ISTJ)}

Myers e McCaulley (1992, p.20) apresentam os ISTJs, Sensação introvertida com pensamento auxiliar, com sendo "Serious, quiet, earn success by concentration and thoroughness. Practical, orderly, matter-of-fact, logical, realistic, and dependable. See to it that everything is well organized. Take responsibility. Make up their own minds as to what should be accomplished and work toward it steadily, regardless of protests or distractions".

Keirsey (1998, p.109) observa que o interesse dos Guardians do tipo Inspectors "in thoroughness, detail, legality, standard procedures, and orderly flow of materiel leads this type to a number of occupations. Inspectors can handle difficult, detailed forms and columns of figures, and thus they make excellent auditors, accountants, or tax attorneys. Investments in securities are likely to interest this type, particularly investments in municipal bonds and blue-chip securities. Inspectors are not likely to take chances either with their own or others' money, and the thought of a bankrupt nation, state, institution, or family gives them more than a little uneasiness. The idea of dishonoring a contract also bothers an ISTJ - their word is their bond and naturally communicate a message of trustworthiness and stability, which can make them successful in business". 
Zacharias (2006, p.188) acrescenta que os ISTJs "Embora raramente o demonstrem publicamente, suas reações emocionais muitas vezes são vividas e intensas. Essa peculiaridade de esconder suas reações mais íntimas as faz parecerem extremamente calmas e seguras quando têm de enfrentar situações de crise. Só quando se conhece bem essas pessoas, é que se percebe que por trás da fachada de calma estão encarando a situação de um ponto de vista extremamente pessoal. Contudo, quando estão em público e têm de lidar com o mundo das realidades concretas, mostram-se extremamente confiáveis e sensatas. Costumam também ser sistemáticas, perseverantes, trabalhadoras e capazes de levar em consideração cada pormenor de um problema, bem como as regras que devem ser seguidas em cada caso. Essa capacidade para a perseverança estabiliza todas as coisas com que entram em contato".

\subsubsection{The Provider (ESFJ)}

De acordo com Keirsey (1998, p.110), "Providing is the act of furnishing others with the necessities of life, and the ESFJs seem eager to serve others, making sure they feel well-supplied with provisions and a part of the group. These Providers take it upon themselves to arrange the physical health and welfare of those in need, but they are also the most sociable of the Guardians, and thus are the great nurturers of established institutions such as schools, churches, social clubs, and civic groups".

Prossegue o autor (1998, p.111) afirmando que "Providers tend to have observable things on their mind rather than imaginary things. They are likely to be 
aware of and enjoy discussing events and problems in people's lives; but when conversations turn to philosophic or scientific abstractions, they may become restive".

Zacharias (2006, p.168) acrescenta que os ESFJs, Sentimento extrovertido com pensamento auxiliar "quando começam um novo projeto ou tarefa, tendem a começar a fazer aquilo que acreditam que deveria ser feito, em vez de parar e pensar e descobrir o que seria mais útil ou necessário".

Keirsey (1998, p.111) adiciona que "Providers are highly sensitive and are not all reluctant to express their emotional reactions. They are quick to like and dislike, tending to put on a pedestal whatever or whomever they admire, and come to down hard on those people and issues they don't care for. Ever conscious of appearances, they take seriously the opinions of others regarding their own acceptability".

\subsubsection{The Protector (ISFJ)}

Segundo Myers e McCaulley (1992, p.20), os ISFJs, Sensação introvertida com sentimento auxiliar, são "Quiet, friendly, responsible, and conscientious. Work devotedly to meet their obligations. Lend stability to any project or group. Thorough painstaking, accurate. Their interests are usually not technical. Can be patient with necessary details. Loyal, considerate, perceptive, concerned with how other people feel".

Zacharias (2006, p.183-184) acrescenta que "As pessoas que pertencem a esse perfil de preferências são extremamente confiáveis e capazes de aceitar 
responsabilidades que vão além de sua obrigação. Costumam ter um respeito completo, realista e prático por fatos concretos. Quando, a partir desses, percebem que é preciso fazer algo, geralmente param para pensar a respeito, e quando decidem que sua ação poderia contribuir para esclarecer a situação, aceitam a responsabilidade por ela. São pessoas que lembram e utilizam um grande número de fatos, dando grande importância à sua fidedignidade. Apreciam muito que tudo seja apresentado da forma mais clara possível".

Keirsey (1998, p.113) acrescenta que "Like all Guardians, they are concrete in communicating and cooperative in implementing their goals. They are preoccupied with morality, and work well with materiel. In orientation, they tend to be fatalistic, pessimistic, and stoical as they guard the gateways and look to yesterday. They base their self-image on being seen as dependable, beneficent, and respectable. Often seriously concerned about things, they trust authority, yearn for belonging, seek security, prize gratitude, and aspire to executive position. Intellectually, they are prone to practice logistics far more than tactics, diplomacy, and especially strategy. Further, being friendly or fond-hearted in nature, they tend to take up the Conservator's roles of Protector and Provider more comfortably than the toughminded Administrator's role of Supervisor and Inspector. And owing to their sense of quiet reserve they seem more comfortable acting as a Protector than a Provider".

\subsubsection{Exemplos de Representantes dos Guardians}

Segundo Keirsey, são apresentados no Quadro 6 - Guardians exemplos do temperamento Guardians. 
Quadro 6 - Guardians

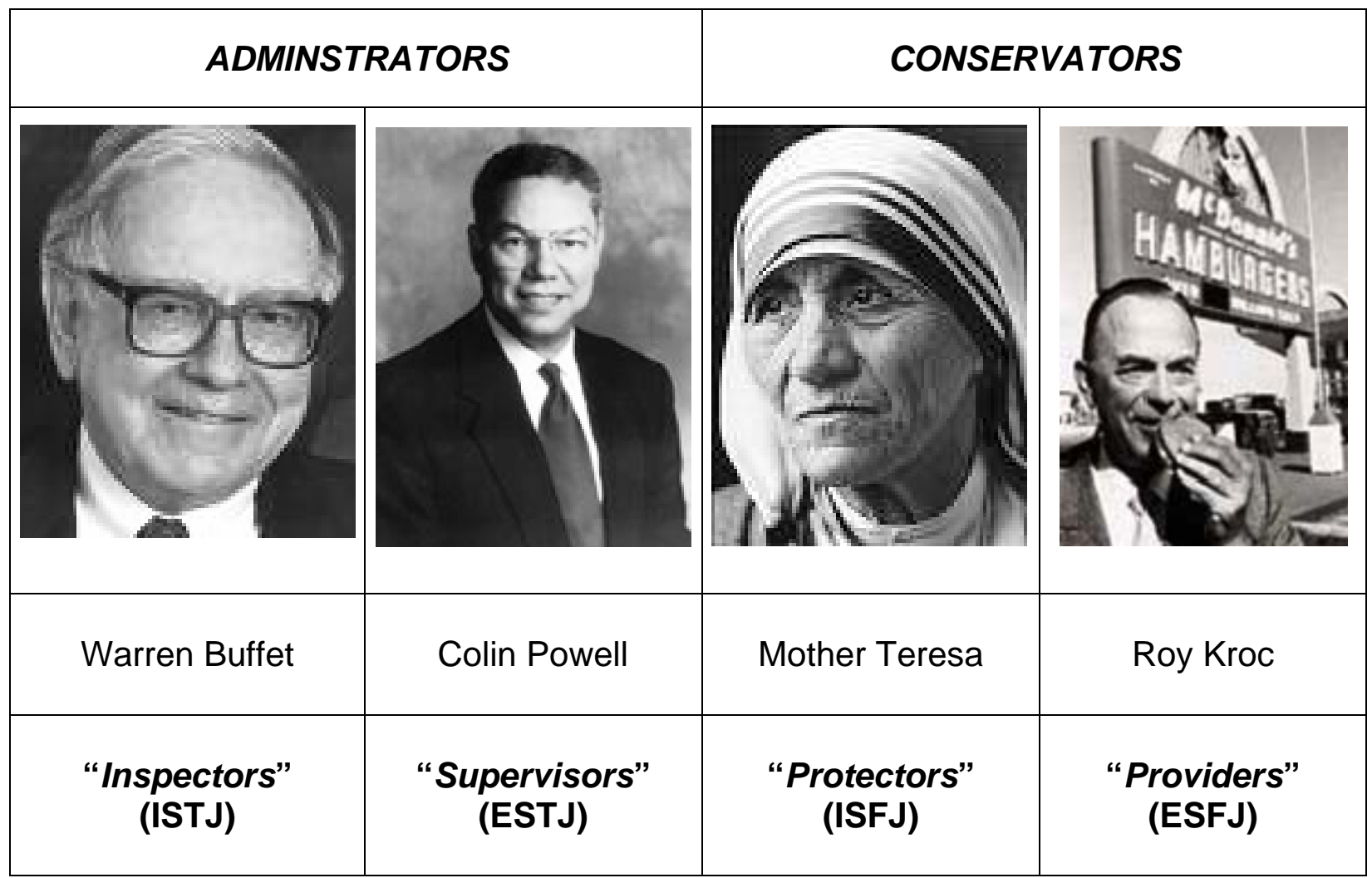

\subsection{Idealists}

A seguir são descritos os tipos psicológicos que se agrupam no temperamento Idealists, isto é: The Teacher, The Counselor, The Champion e The Healer.

\subsubsection{The Teacher (ENFJ)}

Myers e McCaulley (1992, p.21) conceituam os ENFJs, Sentimento extrovertido com função intuição auxiliar, como sendo "Responsive and responsible. Generally feel real concern for what others think or want, and try to handle things with due regard for the other person's feelings. Can present a proposal or lead a group discussion with ease and tact. Sociable, popular, sympathetic. Responsive to praise and criticism". 
Keirsey (1998, p.149) afirma que "Like all the Idealists they are abstract in communicating and cooperative in implementing goals. They want to learn about the humanities, are preoccupied with morale, and work well with personnel. In orientation they are altruistic, credulous, mystical, situated on pathways, and with their eye on tomorrow. They base their self-image on being seen as empathic, benevolent, and authentic. Often enthusiastic, they trust intuition, yearn for romance, seek identity, prize recognition, and aspire wisdom of the sage. Intellectually, they are prone to practice diplomacy far more than strategy, logistics, and especially tactics".

Zacharias (2006, p.159) acrescenta que o maior interesse dos ENFJs é "enxergar as possibilidades que estão além daquilo que está presente, é óbvio ou conhecido. A intuição aguça sua curiosidade por idéias novas, sua visão do futuro e sua capacidade de penetrar além do conhecido. São geralmente pessoas que se interessam pela leitura e pela teoria. É provável que expressem bem suas idéias, mas que usem essa facilidade para se expressar principalmente quando têm que falar em público (já ao escrever nem tanto). Aliás, pensam melhor quando estão falando com outras pessoas do que sozinhas".

\subsubsection{The Counselor (INFJ)}

Segundo Keirsey (1998, p.152), "Counseling is the side of mentoring that focuses on helping people to realize their human potential, and INFJs have an unusually strong desire to contribute to the welfare of others and genuinely enjoy guiding their companions toward great personal fulfillment". 
Myers e McCaulley (1992, p.21) acrescentam que os INFJs, Intuição introvertida com sentimento auxiliar, "Succeed by perseverance, originality, and desire to do whatever is needed or wanted. Put their best efforts into their work. Quietly forceful, conscientious, concerned for others. Respected to their firm principles. Likely to be honored and followed for their clear convictions as to how best to serve the common good".

Keirsey (1998, p.153) observa que "Counselors can be hard to get to know. They have an unusually rich inner life, but they are reserve and tend not to share their reactions except with those they trust. With their loved ones, certainly, they are not reluctant to express their feelings, their face lighting up with the positive emotions, but darkening like as thunderhead with the negative, Because of their strong ability to take into themselves the feelings of others, Counselors can be hurt rather easily by those around them, which, perhaps, is one reason why they tend to be private people, quietly, withdrawing from human contact. At the same time, friends who know them for years may find sides emerging which come as a surprise. Not that Counselors are inconsistent; they value their integrity a great deal, but they have mysterious, intricately woven personalities which sometimes puzzle even them.

This type of Idealist has strong empathic abilities and can become aware of another's emotions or intentions - good or evil - even before that person is conscious of them. Such mind-reading can take the form of feeling the hidden distress or illnesses of others to an extent which is difficult for others types to comprehend. Even INFJs can seldom tell how thy penetrate other's feelings so keenly". 
Zacharias (2006, p.176) afirma que os INFJs "São independentes e individualistas, já que pautam sua vida na intuição. Os dados assim obtidos são tão válidos e importantes para eles, que às vezes custam a entender porque as outras pessoas não os aceitam com tanta facilidade".

\subsubsection{The Champion (ENFP)}

Keirsey (1998, p.155) afirma que "In the view of the Champions nothing occurs that is without significance, without a profound meaning. And they don't want to miss any of it. ENFPs must experience all the events that affect people's lives, and then they are eager to relate the stories they've uncovered, hoping to disclose some truth about people and issues, and to motivate others with their powerful convictions. This strong drive to speak out on social events can make these Champions tireless in conversing with others, like fountains that bubble and splash, spilling over their own words to get it all out. Their enthusiasm is boundless and is often contagious, making them the most vivacious of all types, and also inspiring others to join their cause".

Keirsey (1998, p.156) acrescenta que os ENFPs, Intuição extrovertida com sentimento auxiliar, "have outstanding intuitive powers and often find themselves trying to read what is going on inside of others, interpreting events in terms of another's hidden motives, and giving special meaning to words and actions. While this interpretation can be accurate, it can also be negative, and may introduce an unnecessary toxic element into the relationship". 
Zacharias (2006, p.161) adiciona que os ENFPs "Vislumbram tantas possibilidades novas que têm muitas vezes dificuldades de escolher entre elas aquelas que apresentam o maior potencial. Nesse momento seria útil que entrassem em contato com sua função sentimento , para que esta os ajude a escolher, pesando cuidadosamente o valor de cada alternativa. O julgamento pelo sentimento também pode ajuda-las a tornar seus lampejos intuitivos mais profundos".

\subsubsection{The Healer (INFP)}

Keirsey (1998, p.157-158) afirma que "To the INFP healing means mending those divisions that plague one's private life and one's relationships. It means treating oneself and relating to others in a conciliatory manner, helping to restore lost unity, integrity, or what INFPS calls oneness. These Healers present a tranquil and noticeably pleasant face to the world, but while to all appearances they might seem gentle and easy-going, on the inside they are anything but serene, having a capacity for caring not usually found in other types. Healers care deeply - passionately about a few special persons or a favorite cause, and their fervent aim is to bring peace to the world and wholeness to themselves and their love ones".

Myers e McCaulley (1992, p.21) acrescentam que os INFPs, Sentimento introvertido com intuição auxiliar, são "Full of enthusiasms and loyalties, but seldom talk of these until they know you well. Care about learning, ideas, language, and independent projects of their own, Tend to undertake too much, then somehow get it done. Friendly, but often too absorbed in what they are doing to be sociable. Little concerned with possessions or physical surroundings". 
Zacharias (2006, p.178-179) observa que o interesse principal dos INFPS "está em vislumbrar além do que está presente, do óbvio e do conhecido. São muito mais eficientes quando trabalham em algo que acreditam, já que o sentimento Ihes fornece combustível para seus esforços. Desejam que o trabalho que realizam contribua de alguma forma para com os demais: uma maior compreensão entre as pessoas, um pouco mais de felicidade para alguns, uma melhoria nas condições de saúde. Querem também que seu trabalho Ihes ofereça algo mais do que salário no fim do mês, não importando quão bom seja este. São muito perfeccionistas, quando alguma coisa lhes é cara e importante".

\subsubsection{Exemplos de Representantes dos Idealists}

O Quadro 7 - Idealists apresenta exemplos de temperamento Idealists, conforme descrito por Keirsey. 


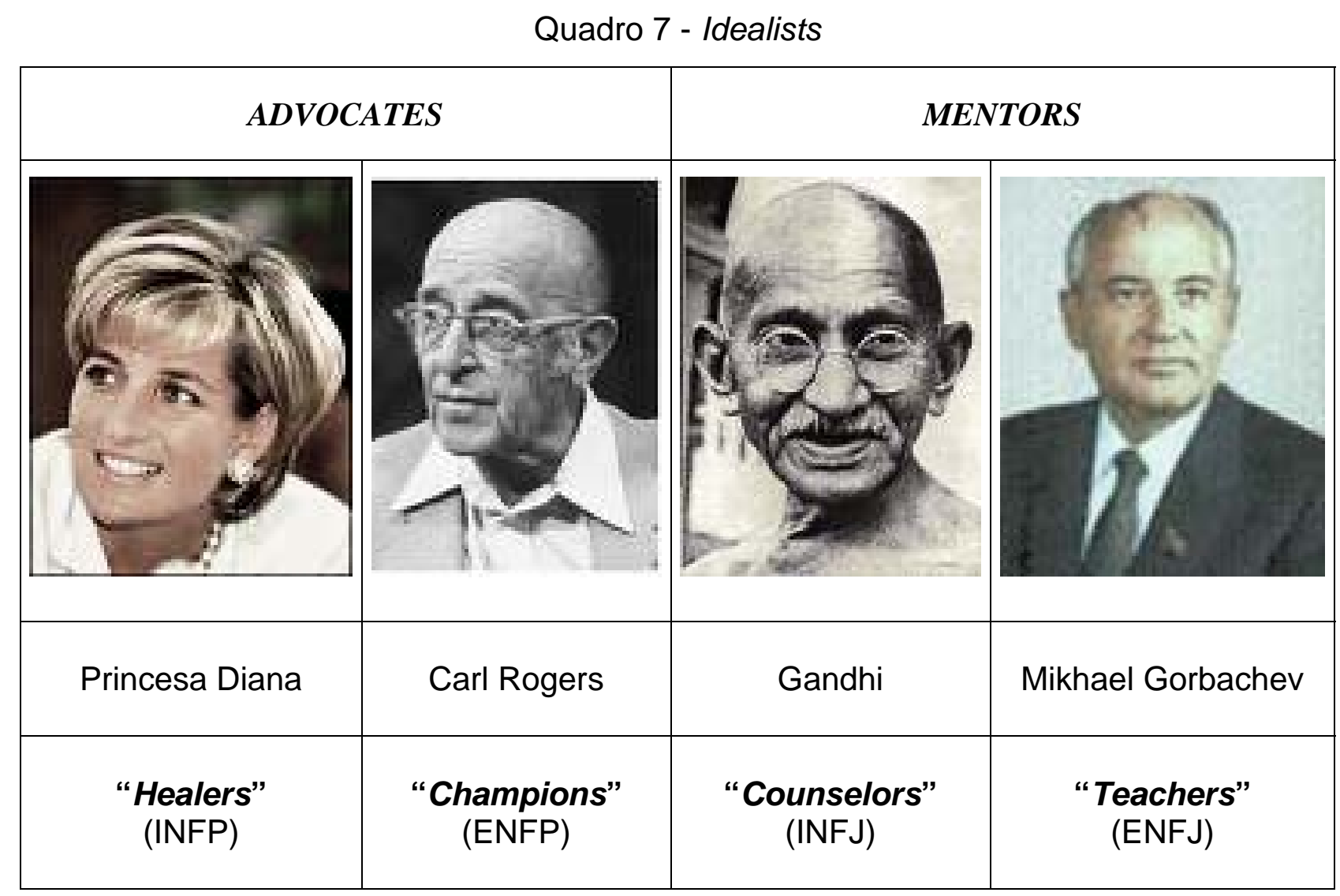

\subsection{Rationals}

São a seguir descritos os tipos psicológicos componentes do temperamento Rationals, assim denominados: The Fieldmarshal, The Mastermind, The Inventor e The Architect.

\subsubsection{The Fieldmarshal (ENTJ)}

Keirsey (1998, p.198) afirma que "These decisive and outspoken Rationals will usually rise to positions of responsibility in the workplace and enjoy being in charge. They are so single-minded and easily caught up in some project or campaign that they can easily block out other areas of life for the sake of their work. Superb executives, they mobilize their forces into smooth-functioning systems, planning in advance, keeping both short-term and long-range objectives well in mind. For the 
ENTJ, there must always be a reason for doing anything, and people's feelings usually are not sufficient reason. More than any other type they are skilled at reducing bureaucracy in any of its forms, and they are willing to dismiss employees who cannot get with the program and increase their efficiency. Although Fieldmarshals are tolerant of some established procedures, they can and will abandon any procedure when it can be shown ineffective in accomplishing its goal. Fieldmarshals are the supreme pragmatists, always aware of the relationship of means to ends. Any procedure the objective of which is no longer pursued is instantly eliminated and its users reassigned to more productive actions".

Segundo Zacharias (2006, p.163) os ENTJ, Pensamento extrovertido com intuição auxiliar, "raramente se sentem satisfeitas em um tipo de trabalho que não utilize a intuição. Os problemas tendem a entusiasmá-las e, portanto, freqüentemente as pessoas desse tipo exercem funções executivas, nas quais podem encontrar e implementar soluções inovadoras. Já que sua atenção está focalizada no quadro mais amplo e mais geral, tendem a negligenciar a importância de certos pormenores. Preferem trabalhar com aqueles, que, como elas, confiam na intuição. Tendem a subestimar certas realidades e geralmente precisam ter junto de si pessoas dotadas de sólido bom senso, que Ihes mostrem facetas negligenciadas e que se responsabilizem por detalhes importantes que devam ser levados em conta". 


\subsubsection{The Mastermind (INTJ)}

Segundo Myers e McCaulley (1992, p.21), os INTJs, Intuição introvertida com pensamento auxiliar, "Usually have original minds and great drive for their own ideas and purposes. In fields that appeal to them, they have a fine power to organize a job and carry it through with, or without help. Skeptical, critical, independent, determined, sometimes stubborn. Most learn to yield less important points in order to win the most important".

Zacharias (2006, p.180) observa que "São pessoas inovadoras incansáveis tanto em pensamento quanto em ação. Confiam na intuição para Ihes fornecer dados sobre os significados reais e as relações verdadeiras dos objetos, não ligando muito para o que as autoridades reconhecidas ou a opinião pública possam pensar sobre essas coisas. A fé que depositam em sua visão interior pode mover montanhas e os problemas nada mais fazem do que estimulá-los: para eles, conseguir o impossível vai demorar um pouco mais de tempo - não muito porém. São os mais independentes dos tipos psicológicos sendo, às vezes, até extremamente teimosos. Valorizam muito a eficiência, tanto a própria quanto a dos outros.

Já que estão tão seguros sobre o valor e a validade de suas inspirações, desejam ardentemente que estas sejam colocadas em prática, aceitas e utilizadas pelas outras pessoas, estando dispostos a não poupar tempo e esforços para que isso seja conseguido. São geralmente resolutos e perseverantes, e muitas vezes irão conseguir que outras pessoas trabalhem quase tão duramente quanto elas. 
Embora suas preferências se encaminhem decididamente para o uso da intuição, são capazes, se necessário, de focalizar sua atenção nos pormenores de uma situação, a fim de que sua visão pode ser realizada" .

Keirsey (1992, p.200) afirma que "Although they are highly capable leaders, INTJs are not at all eager to take command, preferring to stay in the background until others demonstrate their inability to lead ".

\subsubsection{The Inventor (ENTP)}

Segundo Myers e McCaulley (1992, p.21), os ENTPs, Intuição extrovertida com pensamento auxiliar, são "Quick, ingenious, good at many things, Stimulating company, alert and outspoken. May argue for fun on either side of a question. Resourceful in solving new and challenging problems, but may neglect routine assignments. Apt to turn to one new interest after another. Skillful in finding logical reasons for what they want".

Zacharias (2006, p.165) acrescenta que "As pessoas desse tipo percebem, quase como por mágica, o que as outras estão pensando ou sentindo sobre alguém ou alguma coisa, podendo utilizar esse conhecimento para obter apoio para seus projetos. Geralmente, estão mais interessadas em entender do que em julgar outras pessoas. A energia psicológica que essas pessoas têm ao seu dispor é proveniente de uma contínua sucessão de novos projetos; seu universo está sempre repleto de possíveis projetos. O problema é que elas podem estar interessadas por uma tal quantidade de coisas diferentes, que terão dificuldades em focalizar sua atenção em 
qualquer uma delas em particular. Neste caso, o pensamento, sua função auxiliar; pode vir em seu socorro, dando-Ihes a possibilidade de analisar e criticar suas inspirações de forma construtiva e assim ajudar no aprofundamento de seus lampejos intuitivos. O fato de estarem acostumadas em confiar no pensamento torna essas pessoas bastante objetivas tanto no que diz respeito aos projetos em que estão interessadas quanto às pessoas que ocupam um lugar em suas vidas".

\subsubsection{The Architect (INTP)}

De acordo com Zacharias (2006, p.181-182), os INTPs, Pensamento introvertido com intuição auxiliar, "usam o pensamento para encontrar os princípios subjacentes às idéias que lhe chegam à consciência, confiando também no intelecto para desenvolver as conseqüências lógicas desses princípios e antecipar suas conseqüências. São analíticas lógicas e capazes de crítica objetiva.

Provavelmente prestam mais atenção às idéias do que às pessoas que estão por trás das idéias. Preferem organizar conhecimentos e idéias do que atuar nas mais variadas situações; só farão isso se as circunstâncias assim o exigirem.

Geralmente mostram grande curiosidade intelectual. Tendem a ter apenas um pequeno círculo de amigos chegados e apreciam a companhia daqueles que gostam de discutir idéias".

Segundo Keirsey (1992, p.204), "Architectonics is the science of spatial relationships - organization, structure, build, configuration - and Architects from a 
very early age are preoccupied with spatial relativity and systems design. But INTPs must not be thought of as only interested in configuring three-dimensional spaces such as buildings, bridges, and machines; they are also architects of curricula, of corporation, and of all kinds of theoretical systems. In other words, INTPs are men and women whose aim is to design systemic structures and to engineer structural models".

\subsubsection{Exemplos de Representantes dos Rationals}

No Quadro 8 - Rationals, apresentado a seguir, são exemplificados os temperamentos classificados como Rationals por Keirsey.

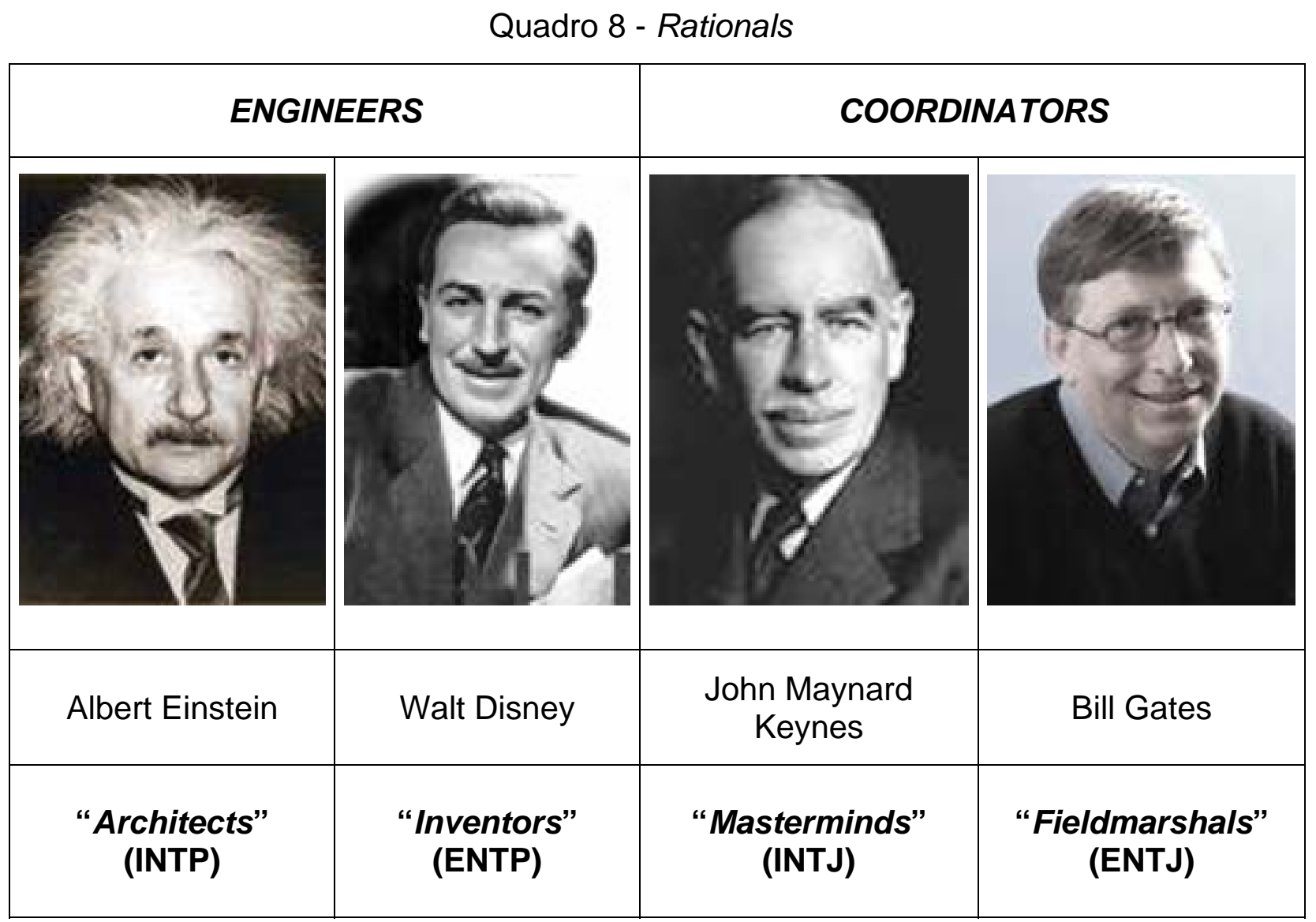




\subsection{Considerações Adicionais}

Farrell (2003, p.59) observa que "the original types created by Carl Jung in 1921 were expanded over the years by the Myers-Briggs team. Jung considered the Extravert-Introvert function one of the most significant in developing his system of eight types, an essential to typecasting people along the Sensor - Intuitive and Thinking - Feeling functions.

Myers and Briggs added the Judging - Perceiving function to distinguish their typology, but they stayed true to Jung's structure and his emphasis on the importance of the Extravert - Introvert opposition".

Já Keirsey propõe a divisão dos indivíduos em quatro temperamentos: Artisans, Guardians, Idealists e Rationals e subdivide cada um deles em quatro subgrupos.

O tipo psicológico busca representar o funcionamento do indivíduo, demonstrando as situações de trabalho e a interação com outros indivíduos. É importante frisar-se que as preferências identificadas não são habilidades ou conhecimentos adquiridos.

Zacharias (2006, p.157) enfatiza que "não é possível definir objetivamente o comportamento e o perfil tipológico de alguém com absoluta certeza. A psique humana é dinâmica e o resultado de qualquer indicador de tipos deve ser compreendido como um indicador que facilite a compreensão do fenômeno humano do ponto de vista geral". 


\section{QUESTÕES OBJETO DESSE ESTUDO}

Há uma significativa quantidade de dados que versa sobre o comportamento do cliente da indústria financeira de varejo.

Os comportamentos de clientes compreendem todo o escopo de sua relação com a indústria financeira de varejo através do consumo de produtos e serviços financeiros, caracterizados pelo ciclo de vida dos mesmos, isto é, aquisição, crescimento, manutenção e declínio no relacionamento com os clientes. As instituições, por sua vez, buscam ampliar o resultado desse relacionamento por intermédio de ações de atração, retenção e fidelização, conforme apresentado na Figura 36 - Ação sobre o Ciclo de Vida de Produtos ou Serviços, p. 151:

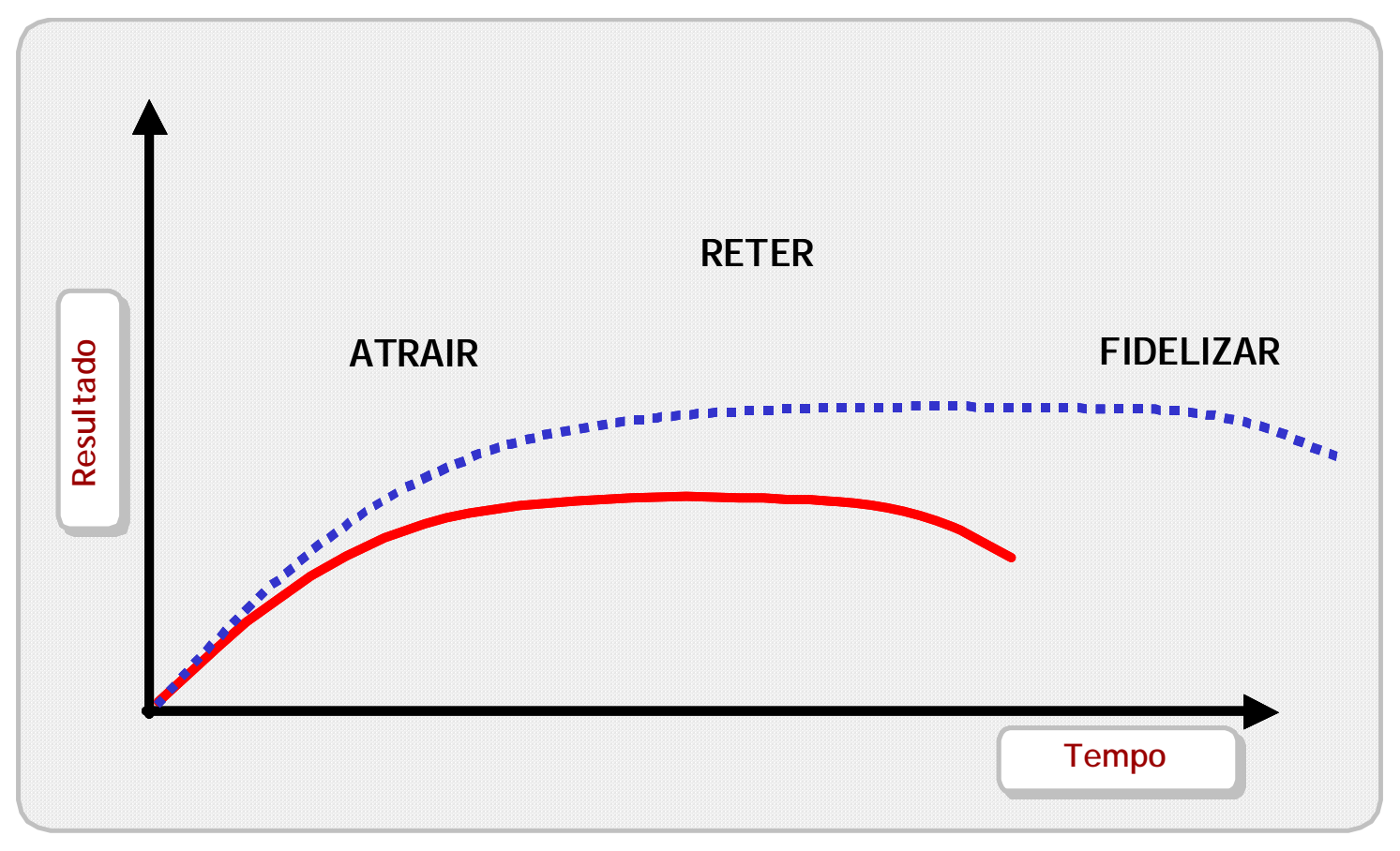

Figura 36 - Ação sobre o Ciclo de Vida de Produtos ou Serviços 
Assim sendo, variáveis como propensão e hábitos de consumo de determinado serviço financeiro e inadimplência são exemplos de padrões de comportamentos observados no relacionamento do cliente da indústria financeira do varejo.

$\mathrm{Na}$ medida em que se aplicam técnicas estatísticas buscando esclarecer padrões e tendências de comportamento dos clientes, procura-se associá-los aos tipos psicológicos descritos na literatura.

Essa associação busca solucionar o seguinte problema: A identificação dos tipos psicológicos dos clientes da indústria financeira de varejo permite explicar os comportamentos desses clientes?

O cartão de crédito é um dos serviços financeiros de varejo que oferece um conjunto de informações mais rico no que se refere aos padrões de utilização, tipos de estabelecimento nos quais se realizam compras, formas de pagamento de faturas, freqüência de uso, entre outras variáveis.

Essa significativa massa de informações permite uma avaliação de seu relacionamento com os tipos psicológicos a partir da qual se formula a seguinte questão:

Os diferentes tipos psicológicos apresentam comportamentos característicos no que concerne aos seus hábitos de uso de cartão de crédito? 
Formula-se assim a primeira hipótese a ser confirmada no presente estudo:

Há correlação entre os tipos psicológicos e os hábitos de consumo de cartão de crédito.

Considerando-se que os clientes se servem das instituições financeiras de varejo para poupança e consumo de recursos financeiros, pode-se estabelecer uma relação entre os padrões de comportamento referentes às propensões para poupar e consumir e os tipos psicológicos?

Giannetti (2005, p.71) ao conceituar troca intertemporal estabelece um paralelo entre juro e desconto que guarda uma relação entre poupança e consumo.

Segundo Giannetti "troca intertemporal implica falar em termo de intercâmbio: a relação entre o que se pagou (custo) e o que se recebeu (benefício) numa dada transação. Juro e desconto são vocábulos que denotam especificamente o termo de intercâmbio contido nas trocas intertemporais. A diferença entre eles é que, enquanto o juro computa os valores de troca do presente para o futuro (o valor adicional que se paga/recebe amanhã por aquilo que se tomou/cedeu hoje), o desconto faz a mesma operação, só que no sentido inverso, ou seja, do futuro para o presente (o valor daquilo que se pagará/receberá amanhã caso isso fosse pago/recebido hoje). Cada um é, portanto, a imagem simétrica invertida do outro: o juro olha a troca intertemporal daqui para lá, e o desconto, de lá para cá. O desconto é o juro no espelho". 
O ato de se poupar ou consumir também está associado à postecipação/antecipação de gratificações.

Será possível estabelecer-se uma relação entre os tipos psicológicos e os hábitos de poupança e consumo de recursos financeiros?

A segunda hipótese formulada nesse trabalho é:

Há correlação entre as propensões a poupar e a consumir e os tipos psicológicos.

No presente trabalho utillizou-se como amostra de clientes de uma instituição financeira de varejo, atendentes de um call center.

Considerando-se que para esses atendentes, encontram-se disponíveis informações relativas ao seu desempenho profissional, avaliado por indicadores de performance comercial, produtividade e qualidade de atendimento, procurou-se estabelecer relação entre o desempenho e os perfis psicológicos.

A terceira hipótese que se levanta na presente pesquisa é:

O desempenho profissional, caracterizado pela performance comercial, produtividade e qualidade de atendimento, está correlacionado com os tipos psicológicos. 
A solução dessas questões permite uma melhor sintonia entre o processo de oferta e demanda de serviços financeiros com os tipos psicológicos, assim como na satisfação dos clientes em questão.

Com o propósito de se refinar a busca de uma relação nas três hipóteses formuladas, os tipos psicológicos foram considerados da seguinte maneira:

Foram avaliadas as dimensões na sua individualidade: Extroversão (E) - , Introversão (I), Sensação (S) - Intuição (N), Pensamento (T) - Sentimento (F) e Julgamento (J) - Percepção (P).

Foram avaliados os temperamentos: Artisans (SP), Guardians (SJ), Idealists (NF) e Rationals (NT).

Foram considerados os tipos: Promoter (ESTP), Crafter (ISTP), Performer (ESFP), Composer (ISFP), Supervisor (ESTJ), Inspector (ISTJ), Provider (ESFJ), Protector (ISFJ), Teacher (ENFJ), Counselor (INFJ), Champion (ENFP), Healer (INFP), Fieldmarshal (ENTJ), Mastermind (INTJ), Inventor (ENTP) e Architect (INTP). 


\section{METODOLOGIA}

\subsection{Selecão da Amostra}

\subsubsection{Critérios de seleção da amostra}

Para o desenvolvimento desse trabalho selecionou-se uma amostra composta por atendentes de um grande call center de uma instituição financeira de varejo.

O call center responde pelo atendimento telefônico dos clientes da instituição, função essa que vem ganhando cada vez mais importância, tendo em vista o crescimento experimentado por essa indústria em termos mundiais nos diversos setores econômicos, motivado pela conveniência que propicia em razão de sua alta disponibilidade e número de serviços oferecidos, capazes de replicar grande parte do existente no mundo físico.

As tendências apresentadas anteriormente de convergência e mobilidade permitem observar que através de outros canais de conveniência tais como auto atendimento e internet banking é possível gerar-se demanda para o atendimento do call center, fato que amplia ainda mais a importância e capacidade de contribuição para o atendimento e o relacionamento desse canal, assim como desperta um maior interesse a respeito do estudo do desempenho do atendente, num ambiente de trabalho de características peculiares. 
O atendente de call center é, de forma geral, um profissional em início de carreira que recebe um grande investimento em treinamento visando dotá-lo de conhecimentos básicos de serviços bancários e técnicas de atendimento.

O grupo selecionado para esse estudo foi composto de atendentes em início de carreira, com idade e salário semelhantes, cujo propósito foi o de se estudar seu comportamento financeiro enquanto clientes de varejo da instituição financeira, seu desempenho profissional e buscar a obtenção de correlação entre esses aspectos e o respectivo tipo psicológico.

Inicialmente buscou-se definir a seleção de amostra com significância estatística contendo dados referentes aos hábitos de consumo financeiro e não financeiro de clientes da indústria financeira de varejo.

A amostra selecionada procurou representar dois importantes papéis:

Agrupamento de clientes de varejo de uma instituição financeira, assemelhando-se a uma empresa cuja folha de pagamento de seus funcionários está vinculada à essa instituição;

Agrupamento de funcionários do qual se observam dados referentes ao seu desempenho profissional, contendo informações a respeito da performance comercial, qualidade no atendimento e produtividade. 
5.1.2 Representatividade da amostra

\begin{tabular}{|l|rc|rc|rr|}
\cline { 2 - 7 } \multicolumn{1}{c|}{} & \multicolumn{2}{c|}{ POPULAÇÃO } & \multicolumn{3}{c|}{ AMOSTRA } \\
\hline Temperamentos & \multicolumn{1}{c|}{ Total } & $\%$ & Total & $\%$ & \multicolumn{1}{c|}{ i.c.95\% } \\
\hline Guardian & 3.040 .200 & $44 \%$ & 465 & $53 \%$ & $46,0 \%$ & $60,1 \%$ \\
Idealist & 2.072 .713 & $30 \%$ & 213 & $24 \%$ & $20,6 \%$ & $28,1 \%$ \\
Rational & 978.539 & $14 \%$ & 166 & $19 \%$ & $15,7 \%$ & $22,2 \%$ \\
Artisan & 846.026 & $12 \%$ & 32 & $4 \%$ & $2,4 \%$ & $4,9 \%$ \\
\cline { 2 - 7 } & $\mathbf{6 . 9 3 7 . 4 7 8}$ & $\mathbf{1 0 0} \%$ & $\mathbf{8 7 6}$ & $\mathbf{1 0 0 \%}$ & & \\
\cline { 2 - 7 } & & & & &
\end{tabular}

\begin{tabular}{|l|rc|rc|rr|}
\hline \multicolumn{1}{|c|}{$\begin{array}{c}\text { Variações dos } \\
\text { Temperamentos }\end{array}$} & Total & $\%$ & Total & $\%$ & \multicolumn{2}{|c|}{ i.c.95\% } \\
\hline Supervisor(ESTJ) & 817.867 & $12 \%$ & 265 & $30 \%$ & $25,9 \%$ & $34,6 \%$ \\
Inspector(ISTJ) & 732.812 & $11 \%$ & 48 & $5 \%$ & $3,9 \%$ & $7,1 \%$ \\
Provider(ESFJ) & 840.311 & $12 \%$ & 129 & $15 \%$ & $12,0 \%$ & $17,5 \%$ \\
Protector(ISFJ) & 649.210 & $9 \%$ & 23 & $3 \%$ & $1,5 \%$ & $3,7 \%$ \\
Teacher(ENFJ) & 523.127 & $8 \%$ & 130 & $15 \%$ & $12,1 \%$ & $17,6 \%$ \\
Champion(ENFP) & 599.779 & $9 \%$ & 60 & $7 \%$ & $5,1 \%$ & $8,6 \%$ \\
Counselor(INFJ) & 492.015 & $7 \%$ & 20 & $2 \%$ & $1,3 \%$ & $3,3 \%$ \\
Healer(INFP) & 457.792 & $7 \%$ & 3 & $0 \%$ & $0,0 \%$ & $0,7 \%$ \\
Fieldmarshal(ENTJ) & 249.691 & $4 \%$ & 134 & $15 \%$ & $12,5 \%$ & $18,1 \%$ \\
Inventor(ENTP) & 161.953 & $2 \%$ & 16 & $2 \%$ & $0,9 \%$ & $2,7 \%$ \\
Mastermind(INTJ) & 360.256 & $5 \%$ & 14 & $2 \%$ & $0,8 \%$ & $2,4 \%$ \\
Architect(INTP) & 206.639 & $3 \%$ & 2 & $0 \%$ & $-0,1 \%$ & $0,5 \%$ \\
Promoter(ESTP) & 185.517 & $3 \%$ & 12 & $1 \%$ & $0,6 \%$ & $2,2 \%$ \\
Operator(ISTP) & 143.286 & $2 \%$ & 1 & $0 \%$ & $-0,1 \%$ & $0,3 \%$ \\
Performer(ESFP) & 321.501 & $5 \%$ & 16 & $2 \%$ & $0,9 \%$ & $2,7 \%$ \\
Composer(ISFP) & 195.722 & $3 \%$ & 3 & $0 \%$ & $0,0 \%$ & $0,7 \%$ \\
\cline { 2 - 5 } & 6.937 .478 & $100 \%$ & $\mathbf{8 7 6}$ & $\mathbf{1 0 0} \%$ & & \\
& & & & & & \\
& & & & &
\end{tabular}

Quadro 9 - População e Amostra

(*) Contém a proporção da População

A "população" refere-se à coleta dos dados estatísticos publicados no site http://www.keirsey.com, cuja contagem refere-se ao somatório daqueles que executam o teste disponível no próprio site. Essa população é composta de testes executados, mundialmente, por internautas visitantes, seja por interesse ou até 
mesmo por simples curiosidade. Já a amostra dos atendentes de call center tem limitações de faixa etária, faixa de renda e estado civil (entre as diferenças mais relevantes).

É importante frisar-se que a amostra de atendentes considerada, por ser composta de funcionários de uma instituição financeira de varejo, submeteu-se a critérios específicos de recrutamento e seleção daquela instituição, resultando num grupo com características comuns em determinados quesitos tais como escolaridade, idade, salário, entre outros.

Por este fato, a amostra não representa a "população", mas aproxima-se muito em algumas das variações de temperamento, como ESFJ e ENTP. 


\subsection{Procedimentos adotados}

Os atendentes foram selecionados de forma aleatória sendo que, a exemplo do realizado por Lopes (2004), a eles foi oferecida a aplicação em caráter voluntário do teste Keirsey Temperament Sorter, disponível via internet no site http://www.keirsey.com, que fornece os resultados de forma on-line, como mostra a Figura 37 - Exemplo de Resultado do Teste Keirsey Temperament Sorter, p.160.

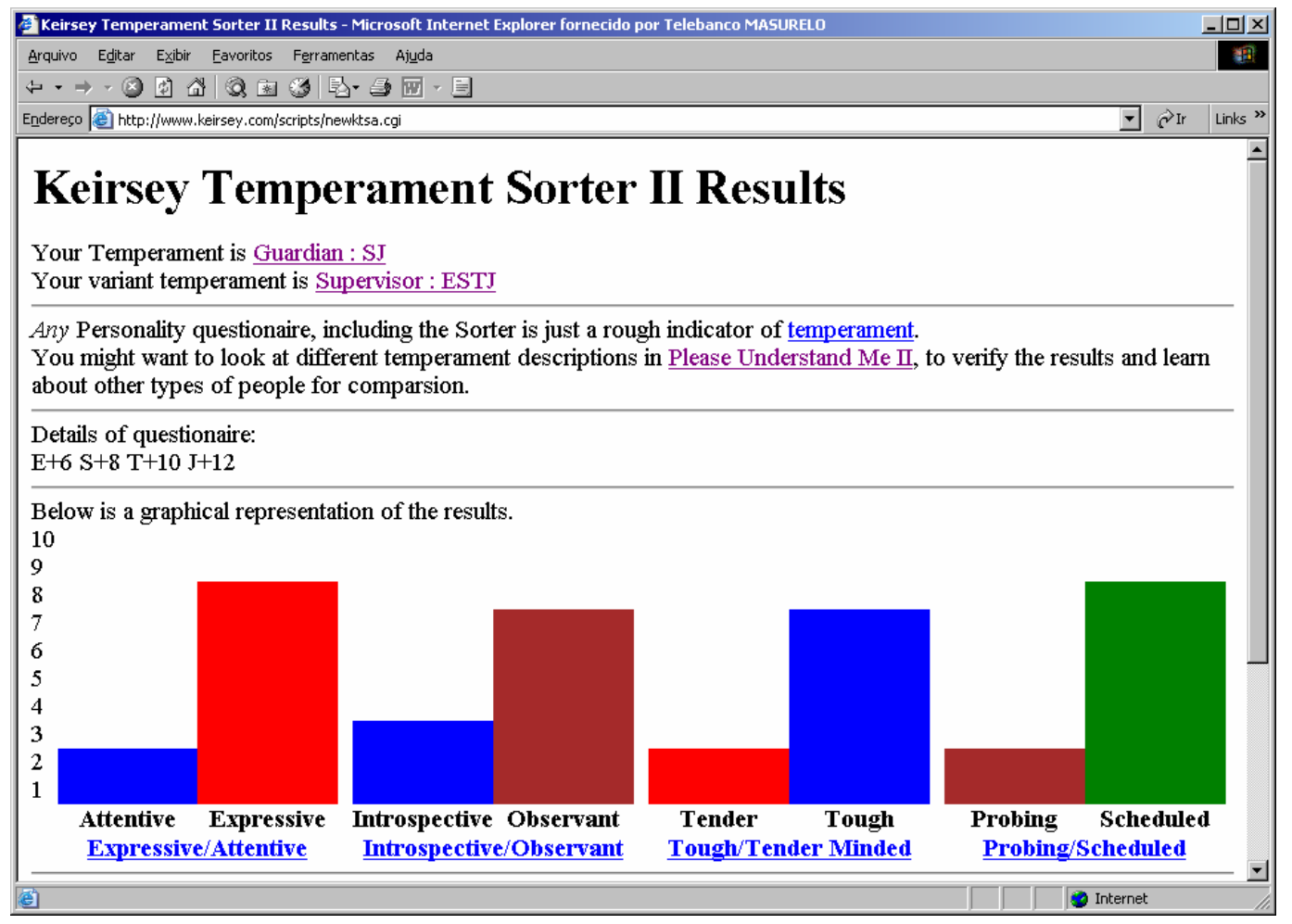

Figura 37 - Exemplo de Resultado do Teste Keirsey Temperament Sorter

Os resultados obtidos a partir da aplicação de cada teste foram armazenados considerando-se a pontuação obtida em cada uma das escalas ExtroversãoIntroversão, Sensação-Intuição, Pensamento-Sentimento e Julgamento-Percepção. 
Dessa maneira, procurou-se obter um conjunto de informações que permitisse uma forma de agrupamento flexível, ou seja o estabelecimento das seguintes distribuições

Por temperamento: Rational, Guardian, Artisan ou Idealist;

Por tipo: Supervisor, Inspector, Provider, Protector, Teacher, Champion, Counselor, Healer, Fieldmarshal, Inventor, Mastermind, Promoter, Operator, Performer, ou Composer.

Por grau de: Extroversão, Introversão, Sensação, Intuição, Pensamento, Sentimento, Julgamento, Percepção.

Uma vez realizado o levantamento de dados que permitiu uma identificação flexível das características referentes aos tipos psicológicos, conforme descrito anteriormente, foram apurados os seguintes comportamentos relativos aos atendentes:

Comportamento referente ao uso de cartão de crédito: Os atendentes foram agrupados em função de seu hábito de uso de cartão de crédito, considerando-se a freqüência de uso do cartão para compras e a freqüência de uso do crédito rotativo, isto é, a faculdade de financiar parte da fatura do cartão de crédito no momento de 
seu vencimento. Esse comportamento pode estar associado à capacidade de se antecipar/postecipar gratificações.

Avaliação segundo a ótica econômica: Nesse item procurou-se apurar indicadores que representam as óticas de poupança e consumo.

Foram apurados indicadores relativos à propensão a poupar, buscando-se relacionar volumes médios mensais apurados em períodos semestrais em conta corrente, poupança, certificados de depósito bancário, aplicações em fundos, previdência privada e títulos de capitalização com a renda auferida pelos atendentes.

Para a determinação da propensão a consumir, foram levantados indicadores das relações existentes entre a média mensal de volumes observados em períodos semestrais de compras com cartão de crédito, crédito rotativo, crédito pessoal, utilização de cheque especial, empréstimos e renegociações de dívida com a renda dos atendentes.

No concernente ao desempenho profissional dos atendentes, foram pesquisados os indicadores que refletem sua produtividade, qualidade no atendimento e montante de vendas realizadas. 
O período utilizado para a apuração dos indicadores citados foi de dezembro de 2005 a maio de 2006 .

No Quadro 10 - Variáveis obtidas no teste Keirsey Temperament Sorter, apresentado na seqüência, observa-se as variáveis resultantes da aplicação do teste:

\begin{tabular}{|c|c|c|c|}
\hline \multicolumn{4}{|c|}{ 4 Temperamentos } \\
\hline Rational & Guardian & Artisan & Idealist \\
\hline \multicolumn{4}{|c|}{16 Tipos } \\
\hline Supervisor (ESTJ) & Inspector (INTJ) & Provider (ESFJ) & Protector (ISFJ) \\
\hline Teacher (ENFJ) & Champion (ENFP) & Counselor (INFJ) & Healer (INFP) \\
\hline Fieldmarshal (ENTJ) & Inventor (ENTP) & Mastermind (INTJ) & Architect (INTP) \\
\hline Promoter (ESTP) & Operator (ISTP) & Performer (ESFP) & Composer (ISFP) \\
\hline \multicolumn{2}{|c|}{8 Graus de Preferências } \\
\hline Extroversão (E) & Introversão (I) & Sensação (S) & Intuição (N) \\
\hline Pensamento (T) & Sentimento (F) & Julgamento (J) & Percepção (P) \\
\hline
\end{tabular}

Quadro 10 - Variáveis obtidas no teste Keirsey Temperament Sorter

No Quadro 11 - Indicadores Utilizados, são apresentados os indicadores utilizados na pesquisa referentes ao comportamento de crédito, ótica econômica de propensão a poupar e a consumir e desempenho profissional. 


\section{Comportamento de Crédito}

Análise de clusters com variáveis de cartão de crédito para identificação de padrões de comportamento, resultando nos grupos: Novo/Esporádico, Rotativo, Compras e Freqüente.

\section{Ótica Econômica}

Ótica de Poupança: Volumes de Conta Corrente, Poupança, CDB, Fundos, Previdência e Capitalização sobre a Renda.

Ótica de Consumo: Volumes de Compras, Rotativo, Cheque Especial, Empréstimos e Renegociação sobre a Renda

\section{Desempenho Profissional}

Indicadores de Desempenho Profissional e Performance Comercial de Quantidade de Produtos/ Serviços Comercializados

\section{Quadro 11 - Indicadores Utilizados}

Em seguida, fez-se uso de ferramentas estatísticas visando-se a identificação de associação entre os atendentes da central de call center, seus tipos psicológicos com as variáveis que descrevem seus hábitos de uso de cartão de crédito, propensão a poupar, propensão a consumir e seu desempenho profissional, procurando-se encontrar uma associação positiva entre os mesmos. 


\subsection{Método de Análise dos Dados}

A metodologia de análise dos dados consiste em explorar de quais formas as características, ou variáveis, psicológicas dos indivíduos podem influenciar em seu comportamento financeiro. "Variável é uma característica da unidade elementar que pode ter valores diferentes entre as unidades medidas" (Lapponi, 2000, p. 4).

O dados foram explorados de forma univariada, bivariada ou multivariada, pois foram tratados, respectivamente, de forma isolada, aos pares de variáveis e mais de duas variáveis.

Para conhecimento da amostra selecionada, foi utilizada Estatística Descritiva para descrever os dados de forma isolada, por meio de representação gráfica e distribuição de freqüências das características ou atributos, tanto psicológicos, quanto demográficos e de comportamento financeiro.

A análise bivariada entre variáveis de tipos psicológicos e as de comportamento financeiro foi utilizada em estudos de associações e correlações.

As variáveis levantadas na aplicação do teste possuem características que determinaram as técnicas estatísticas analisadas no decorrer deste estudo. Uma variável será qualitativa quando resultar de uma classificação por tipos ou atributos e será quantitativa quando seus valores forem expressos em números (Costa Neto, Pedro Oliveira, 1977, p. 6) 
A classificação em quatro temperamentos, assim como suas dezesseis variações, foi utilizada como variável qualitativa de perfil psicológico

A graduação numérica das dimensões dos temperamentos foi reespecificada com a finalidade de criar intervalos que viessem a agrupar graus de dimensão com intensidades semelhantes.

Segundo (Malhotra; Naresh, 1999), a necessidade de se reespecificar variáveis envolve a transformação dos dados para criação de novas variáveis ou modificação de variáveis existentes, com a finalidade de criar variáveis que sejam consistentes com o objeto do estudo.

Assim sendo, as graduações numéricas foram transformadas em faixas de valores, a fim de que representassem a intensidade das dimensões num mesmo eixo: de Extrovertido a Introvertido; de Sensação a Intuição; de Pensamento a Sentimento; e de Julgamento a Percepção. O resultado dessa categorização foi a criação de quatro novas variáveis qualitativas ordinais, utilizando-se o seguinte critério:

Cada "lado" do eixo da dimensão (exemplo: lado da atitude Extroversão e lado da atitude Introversão) foi dividido de acordo com a distribuição dos dados, por um ponto mediano, de modo que fosse dividida entre os $50 \%$ menores, os quais foram classificados em uma faixa denominada "normal", e os 50\% maiores, os quais foram classificados em uma faixa denominada "extremo". Os indivíduos com pontuação nula foram considerados "neutros" do ponto de vista psicológico, segundo a dimensão avaliada. 
As faixas criadas distribuem-se como segue:

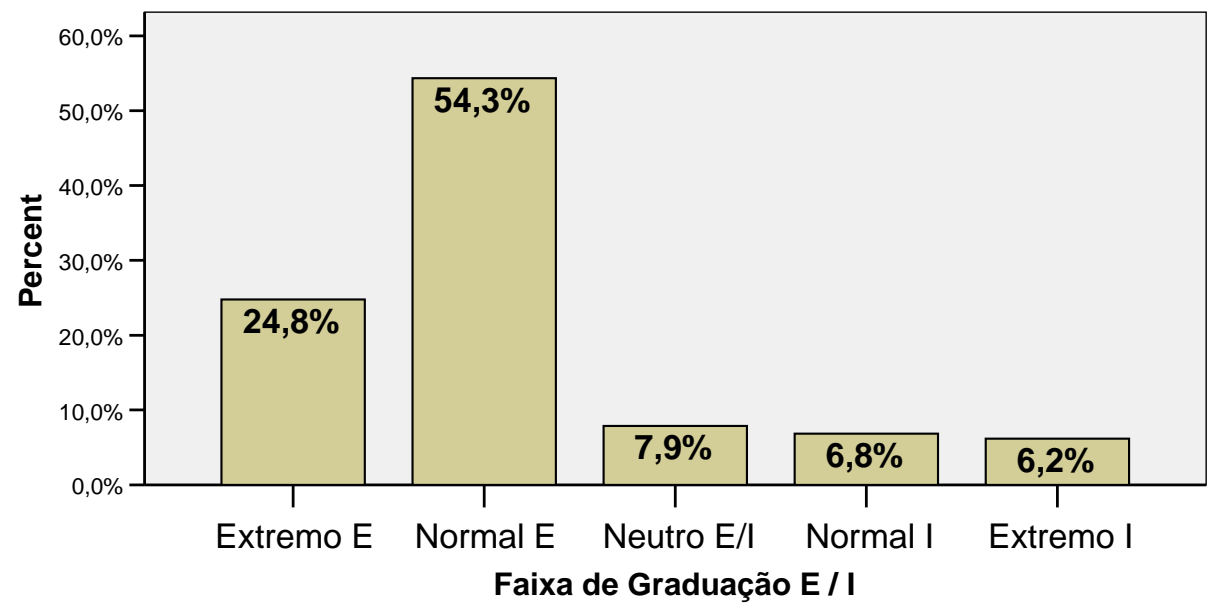

Gráfico 1 - Faixa de Graduação E/I

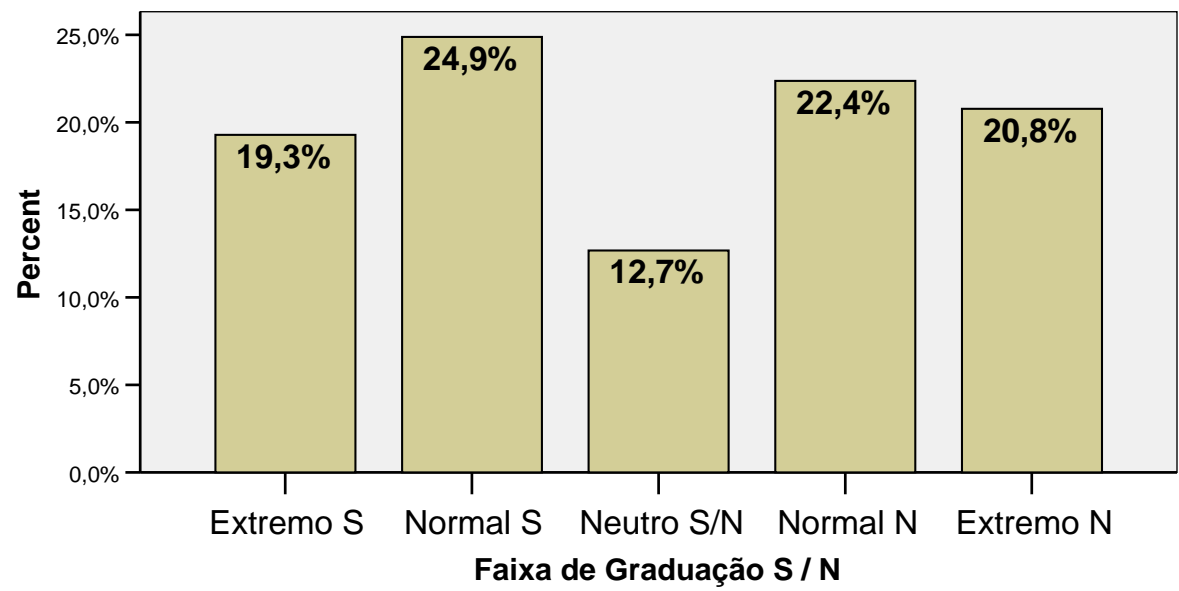

Gráfico 2 - Faixa de Graduação S/N 




Gráfico 3 - Faixa de Graduação T/F

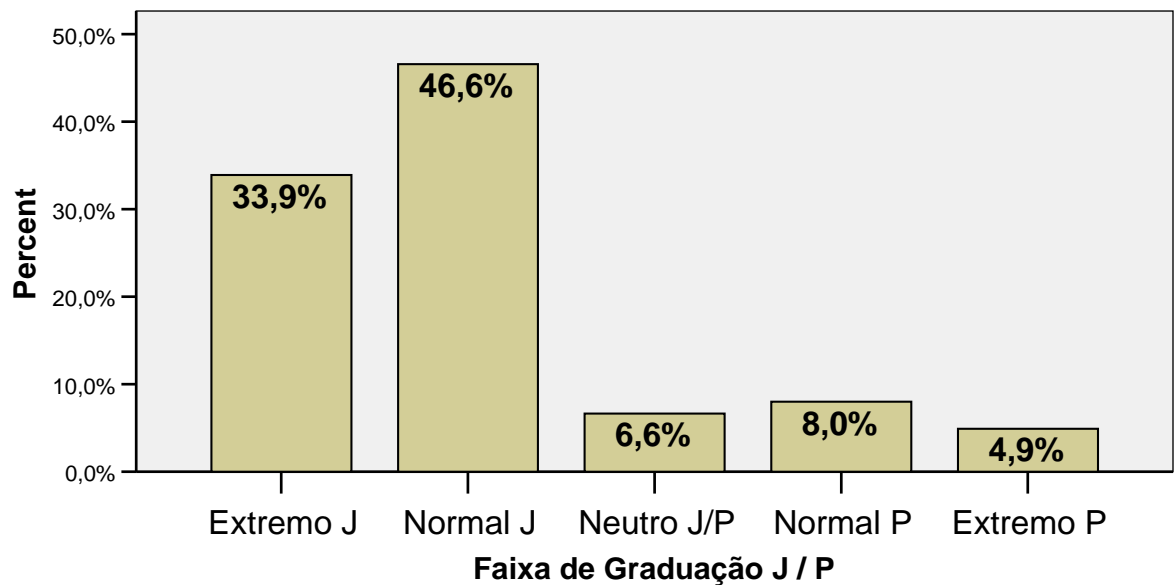

Gráfico 4 - Faixa de Graduação J/P 


\subsection{Testes Estatísticos}

As variáveis independentes (ou explicativas) desse estudo são os tipos psicológicos, considerando-se todos os elementos que os compõem, ou seja, as variáveis que descrevem atitudes, funções e dimensões, os temperamentos e os tipos propriamente ditos.

As variáveis referentes ao perfil psicológico: 8 dimensões, 16 tipos psicológicos, 4 temperamentos foram tratadas como variáveis qualitativas. Os graus das dimensões, obtidos na aplicação do teste Keirsey Temperament Sorter, foram reespecificadas como variáveis qualitativas ordinais.

As variáveis dependentes (ou resposta) são aquelas que descrevem o comportamento com o uso do cartão de crédito, a propensão a poupar e a consumir serviços financeiros e o desempenho profissional, representado pelas variáveis qualidade no atendimento, produtividade e performance comercial. Essas variáveis foram reespecificadas como variáveis qualitativas ordinais.

O Quadro 12 - Testes Estatísticos, p 170, apresentada a seguir, resume as variáveis utilizadas e os testes adequados à análise das mesmas. 


\begin{tabular}{|c|c|c|c|c|}
\hline $\begin{array}{l}\text { VARIÁVEIS } \\
\text { EXPLICATIVAS }\end{array}$ & TIPO & $\begin{array}{l}\text { VARIÁVEIS } \\
\text { RESPOSTA }\end{array}$ & TIPO & TESTE ESTATÍSTICO \\
\hline $\begin{array}{l}4 \text { Temperamentos, } \\
16 \text { Tipos, } \\
8 \text { Dimensões. }\end{array}$ & $\begin{array}{l}\text { Qualitativa } \\
\text { Nominal }\end{array}$ & \begin{tabular}{|l} 
Demográficas \\
Utilização de Produtos \\
Bancários \\
Segmentos de Cartão \\
de Crédito criados por \\
Análise de Cluster, \\
Faixas de Valores de \\
Uso de Cartão de \\
Crédito
\end{tabular} & $\begin{array}{l}\text { Qualitativa } \\
\text { Nominal }\end{array}$ & $\begin{array}{l}\text { Análise de } \\
\text { associação com } \\
\text { Teste Qui-quadrado }\end{array}$ \\
\hline \begin{tabular}{|lr} 
Faixas & de \\
Graduação & das \\
Dimensões &
\end{tabular} & $\begin{array}{l}\text { Qualitativa } \\
\text { Ordinal }\end{array}$ & \begin{tabular}{|l} 
Faixas de \% de \\
Comprometimento da \\
Renda com Variáveis \\
de Consumo e \\
Poupança \\
Faixas de \\
Desempenho \\
Profissional
\end{tabular} & $\begin{array}{l}\text { Qualitativa } \\
\text { Ordinal }\end{array}$ & $\begin{array}{l}\text { Análise de associação } \\
\text { utilizando teste } \\
\text { Somers'd, adequado } \\
\text { para variáveis ordinais }\end{array}$ \\
\hline
\end{tabular}




\subsection{Resultado da Aplicação do Teste Keirsey Temperament Sorter}

Os Temperamentos:

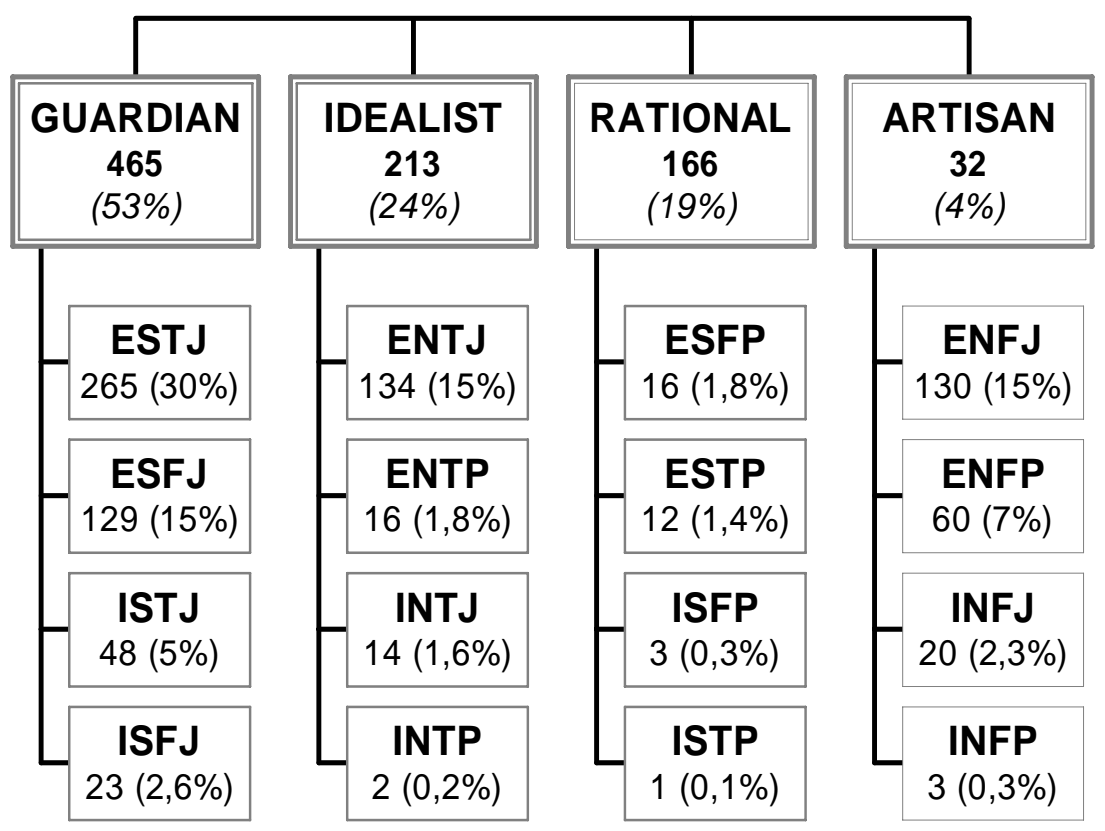

Figura 38 - Os Temperamentos: Resultado da Pesquisa

Considerando a classificação entre os 4 temperamentos, a maior concentração se dá no perfil Guardian, principalmente na sua variação ESTJ. O perfil menos comum da amostra é o Artisan. 
As Dimensões dos temperamentos:

\begin{tabular}{|c|c|c|c|}
\hline \multicolumn{4}{|c|}{$\begin{array}{c}\text { Extroversão (E) - Introversão (I) } \\
\text { perfil_El }\end{array}$} \\
\hline & & Frequency & Percent \\
\hline \multirow[t]{3}{*}{\begin{tabular}{|l} 
Valid \\
\end{tabular}} & Extrover & & 87,0 \\
\hline & Introve & & 13 \\
\hline & Total & 876 & 100,0 \\
\hline
\end{tabular}

Quadro 13 - Distribuição de Freqüências Extrovertidos / Introvertidos

\begin{tabular}{|ll|r|r|}
\hline \multicolumn{3}{|c|}{ Sensação (S) - Intuição (N) } \\
perfil_SN \\
\hline & Frequency & Percent \\
\hline Valid & Sensação & 497 & 56,7 \\
& Intuição & 379 & 43,3 \\
& Total & 876 & 100,0 \\
\hline
\end{tabular}

Quadro 14 - Distribuição de Freqüências Sensação / Intuição

\begin{tabular}{|c|c|c|c|}
\hline \multicolumn{4}{|c|}{$\begin{array}{c}\text { Pensamento }(T) \text { - Sentimento }(F) \\
\text { perfil_tF }\end{array}$} \\
\hline & & Frequency & Percent \\
\hline \multirow[t]{3}{*}{$\begin{array}{l}\text { Valid } \\
\end{array}$} & Pensamento & 492 & 56,2 \\
\hline & Sentimento & 384 & 43,8 \\
\hline & Total & 876 & 100,0 \\
\hline
\end{tabular}

Quadro 15 - Distribuição de Freqüências Pensamento / Sentimento

\begin{tabular}{|c|c|c|c|}
\hline \multicolumn{4}{|c|}{$\begin{array}{c}\text { Julgamento }(\mathrm{J}) \text { - Percepção }(\mathrm{P}) \\
\text { perfil_JP }\end{array}$} \\
\hline & & Frequency & Percent \\
\hline \multirow[t]{3}{*}{\begin{tabular}{|l} 
Valid \\
\end{tabular}} & Julgamento & 763 & 87,1 \\
\hline & Percepção & 113 & 12,9 \\
\hline & Total & 876 & 100,0 \\
\hline
\end{tabular}

Quadro 16 - Distribuição de Freqüências Julgamento / Percepção 


\section{PERFIL DA BASE}

Neste tópico, são apresentadas as características gerais da amostra estudada, através da representação gráfica das freqüências de dados demográficos e de produtos bancários dos indivíduos.

\subsection{Demográfico}

\subsubsection{Distribuição por Sexo}

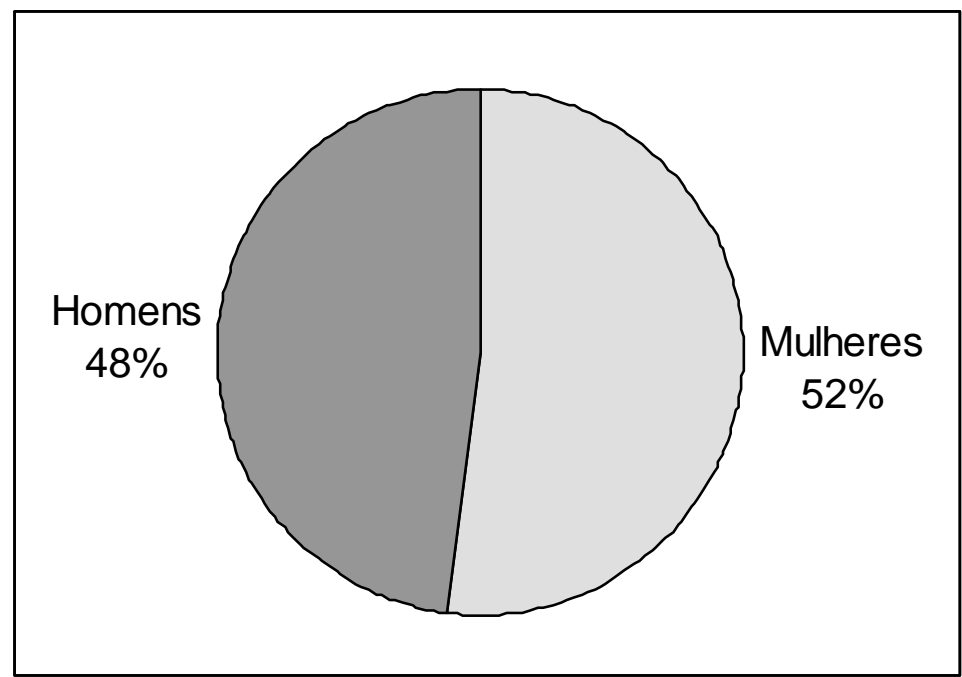

Gráfico 5 - Distribuição por Sexo 


\subsubsection{Distribuição por Estado Civil}

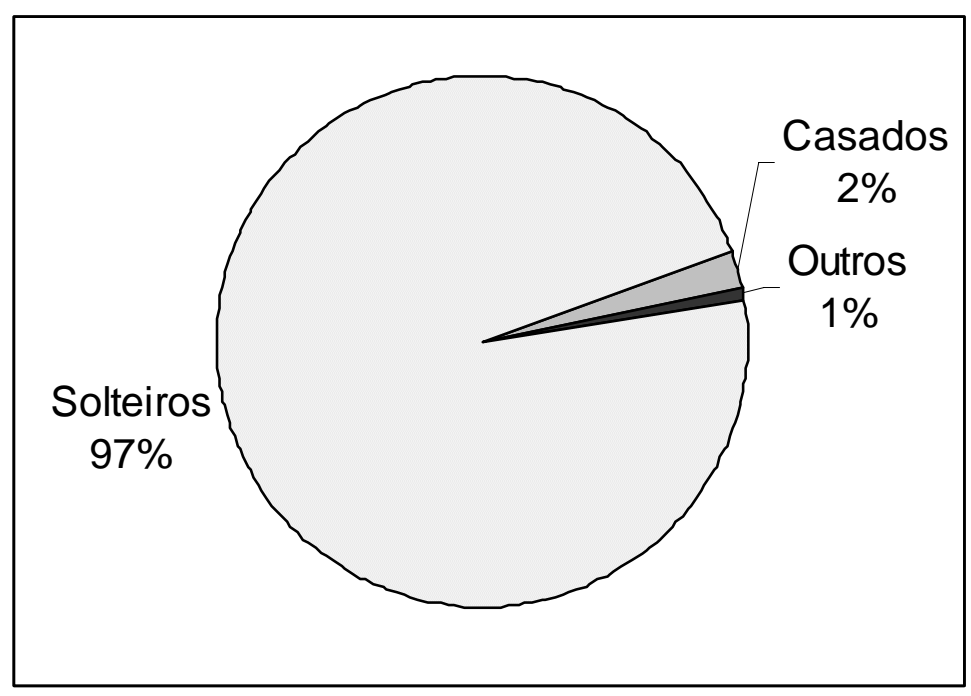

Gráfico 6 - Distribuição por Estado Civil

\subsubsection{Distribuição por Faixa Etária}

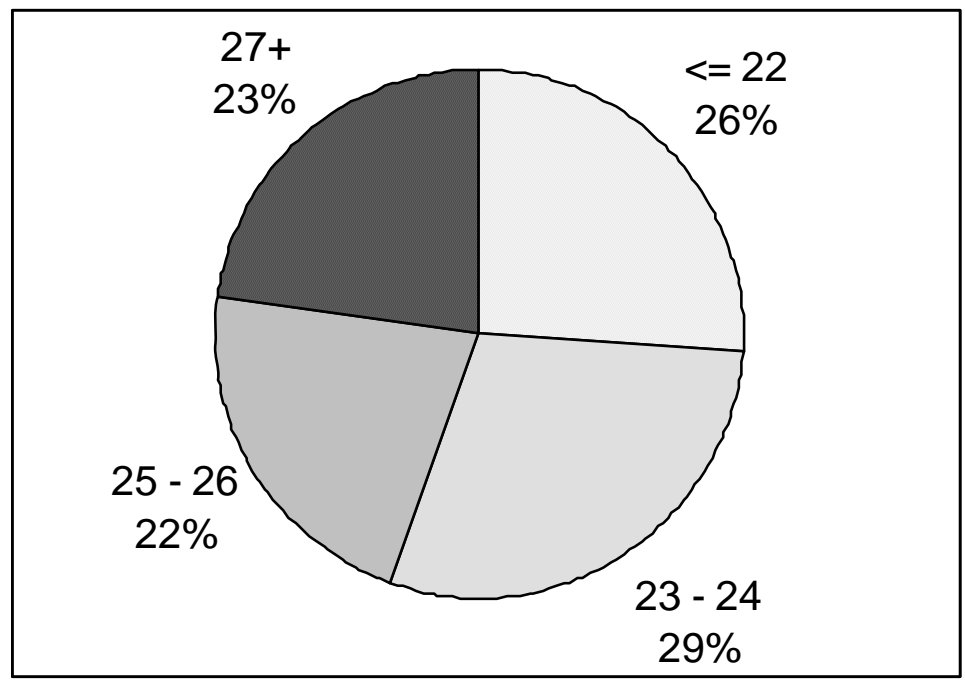

Gráfico 7 - Distribuição por Faixa Etária 


\subsubsection{Distribuição por Região Geográfica}

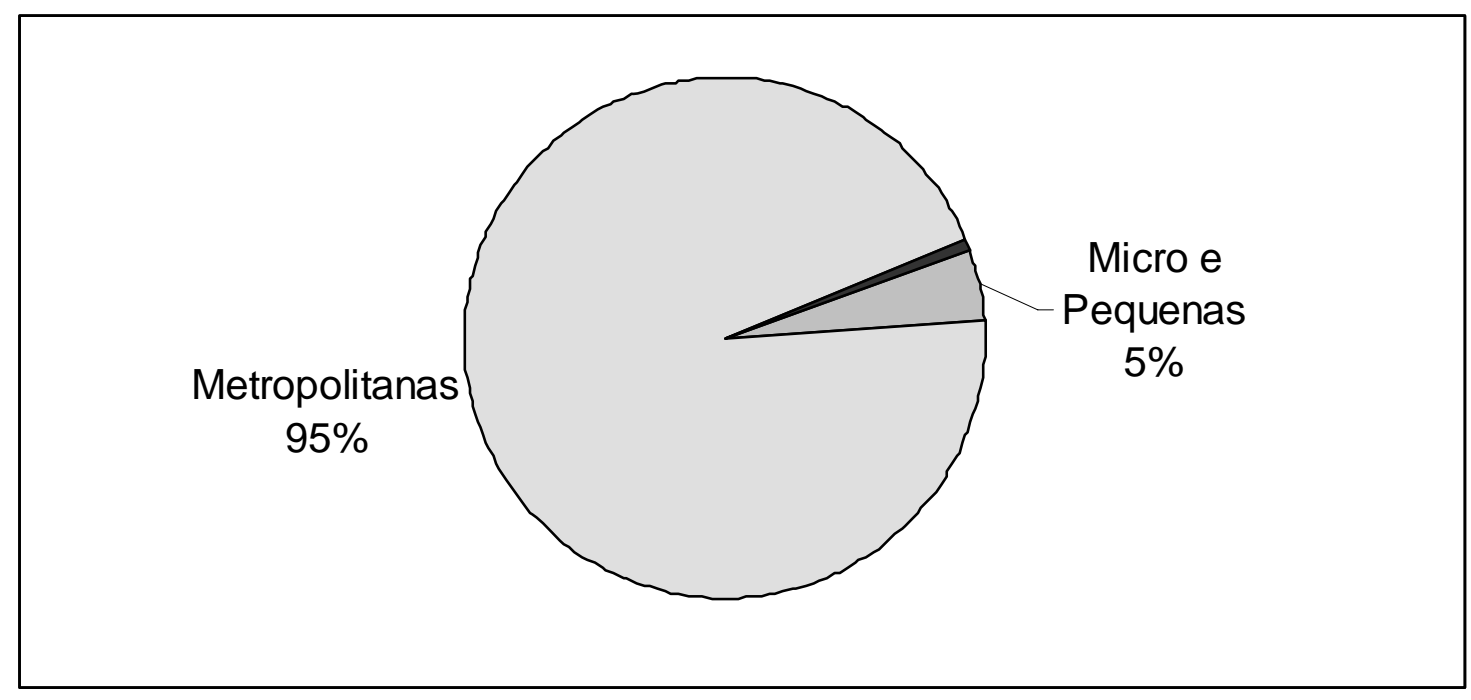

Gráfico 8 - Distribuição por Regiões Geográficas

A amostra é composta, na maioria, de jovens entre 18 e 30 anos, solteiros, residentes em regiões metropolitanas. 


\subsection{Relacionamento com o Banco}

\subsubsection{Distribuição por Tempo de Relacionamento}

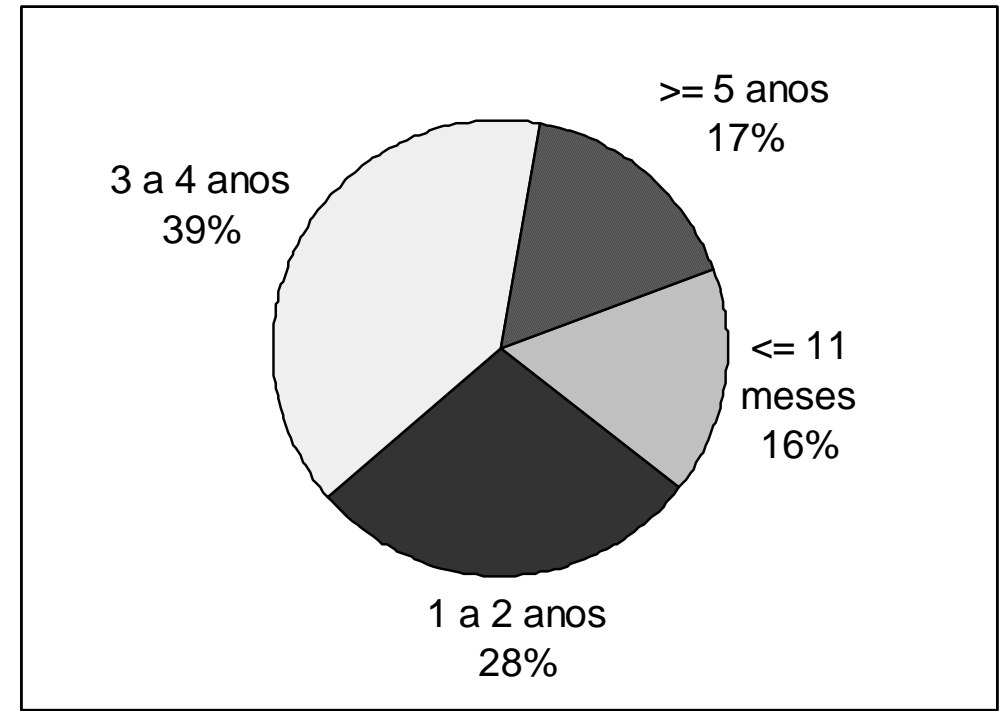

Gráfico 9 - Distribuição por Tempo de Relacionamento

\subsubsection{Distribuição por Posse de Cartão de Crédito}

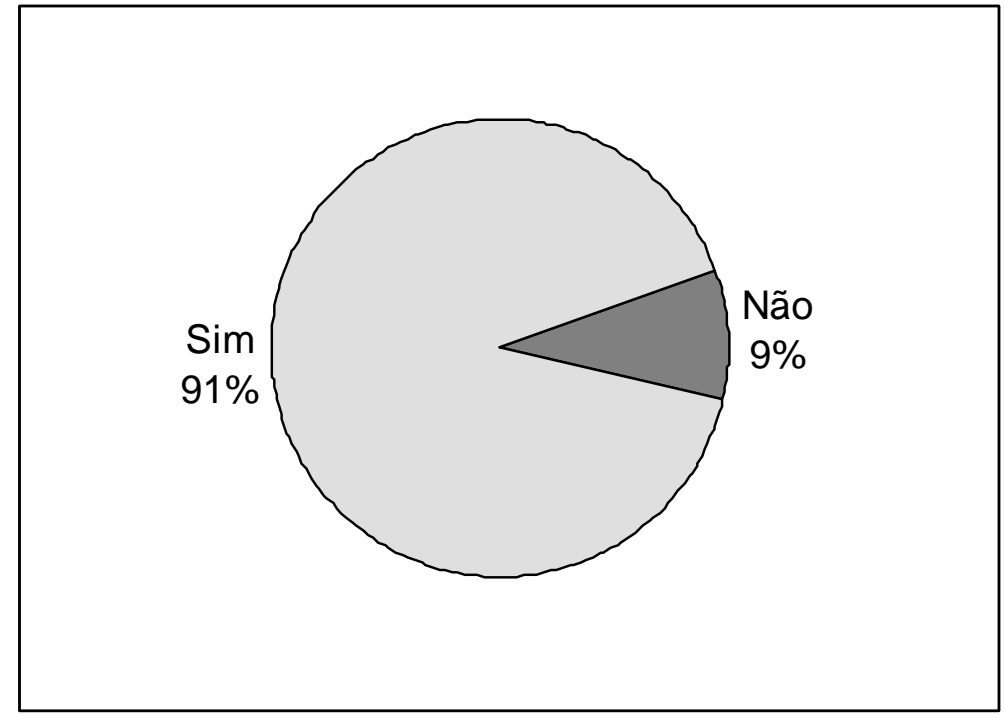

Gráfico 10 - Distribuição por Posse de Cartão de Crédito 


\subsubsection{Distribuição por Utilização de Produtos Bancários}

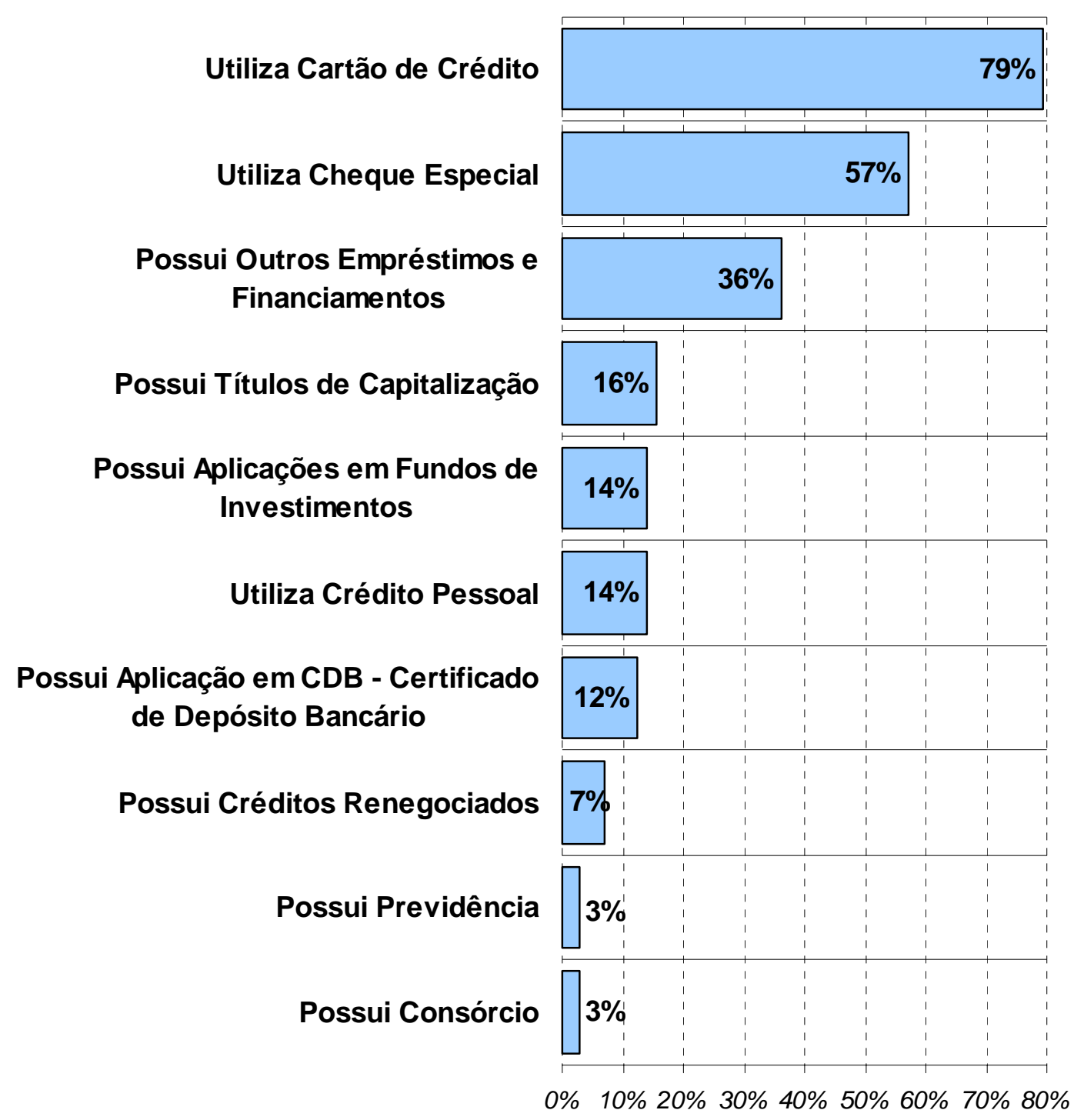

Gráfico 11 - Utilização de Produtos Bancários

A grande maioria possui cartão de crédito, sendo que $79 \%$ da amostra utiliza o cartão para compras e/ou saques.

As maiores concentrações estão em produtos de crédito, como a utilização do cheque especial e empréstimos. 


\section{ASSOCIAÇÕES E CORRELAÇÕES}

\subsection{Relação Temperamentos vs. Perfil da Base}

O objetivo desse item é avaliar o relacionamento entre os Temperamentos e o Perfil da Base.

O estudo de associações foi feito através do cruzamento entre as classificações dos 4 Temperamentos e suas 16 variações com:

- Variáveis Demográficas (sexo, estado civil e região geográfica);

- Variáveis de Relacionamento com o Banco (posse de produtos).

Portanto, cruzam-se todos os 4 temperamentos, e suas 16 variações de perfil psicológico, com os atributos demográficos e de produtos bancários dos indivíduos. 


\subsubsection{Perfil Psicológico vs. Perfil Demográfico}

\subsubsection{Sexo vs. Perfil Psicológico}

- Os 4 Temperamentos vs. Sexo

\begin{tabular}{|c|r|r|r|r|r|r|}
\hline \multirow{2}{*}{} & \multicolumn{4}{|c|}{ Sexo } & \multicolumn{2}{c|}{} \\
\cline { 2 - 5 } & \multicolumn{2}{|c|}{ Mulheres } & \multicolumn{2}{c|}{ Homens } & \multicolumn{2}{c|}{ Total } \\
\cline { 2 - 5 } & Qtde & \multicolumn{1}{|c|}{$\%$} & \multicolumn{1}{c|}{ Qtde } & \multicolumn{1}{c|}{ Qtde } & \multicolumn{1}{c|}{$\%$} \\
\hline Rational & 61 & $13,4 \%$ & 105 & $24,9 \%$ & 166 & $18,9 \%$ \\
Idealist & 122 & $26,9 \%$ & 91 & $21,6 \%$ & 213 & $24,3 \%$ \\
Artisan & 16 & $3,5 \%$ & 16 & $3,8 \%$ & 32 & $3,7 \%$ \\
Guardian & 255 & $56,2 \%$ & 210 & $49,8 \%$ & 465 & $53,1 \%$ \\
Total & 454 & $100,0 \%$ & 422 & $100,0 \%$ & 876 & $100,0 \%$ \\
\hline
\end{tabular}

Quadro 17 - Tabela Cruzada: Os 4 Temperamentos vs. Sexo

Chi-Square Tests

\begin{tabular}{|c|c|c|c|}
\hline & Value & df & $\begin{array}{l}\text { Asymp. Sig. } \\
\text { (2-sided) }\end{array}$ \\
\hline $\begin{array}{l}\text { Pearson Chi-Square } \\
\mathrm{N} \text { of Valid Cases }\end{array}$ & $\begin{array}{r}19,386 \\
876\end{array}$ & 3 & ,000 \\
\hline
\end{tabular}

Quadro 18 - Teste Qui-quadrado: Os 4 Temperamentos vs. Sexo

Teste Qui-quadrado: Há evidências que permitem rejeitar a hipótese nula de não associação das variáveis, ou seja, as evidências indicam a associação das variáveis sexo e Perfil Psicológico.

O percentual de homens com o perfil Rational, por exemplo, é de $24,9 \%$, enquanto apenas 13,4\% das mulheres têm esse perfil. Já as mulheres concentramse mais entre os Guardians e os Idealists do que os homens. 
- As 16 Variações de Temperamentos vs. Sexo

\begin{tabular}{|c|r|r|r|r|r|r|}
\hline & \multicolumn{4}{|c|}{ Sexo } & \multicolumn{2}{c|}{} \\
\cline { 2 - 6 } & \multicolumn{2}{|c|}{ Mulheres } & \multicolumn{2}{|c|}{ Homens } & \multicolumn{2}{c|}{ Total } \\
\cline { 2 - 6 } & Qtde & \multicolumn{1}{|c|}{ Qtde } & \multicolumn{1}{c|}{ Qtde } & \multicolumn{1}{c|}{$\%$} \\
\hline ENFJ & 70 & $15,4 \%$ & 60 & $14,2 \%$ & 130 & $14,8 \%$ \\
ENFP & 36 & $7,9 \%$ & 24 & $5,7 \%$ & 60 & $6,8 \%$ \\
ENTJ & 53 & $11,7 \%$ & 81 & $19,2 \%$ & 134 & $15,3 \%$ \\
ENTP & 4 &, $9 \%$ & 12 & $2,8 \%$ & 16 & $1,8 \%$ \\
ESFJ & 84 & $18,5 \%$ & 45 & $10,7 \%$ & 129 & $14,7 \%$ \\
ESFP & 7 & $1,5 \%$ & 9 & $2,1 \%$ & 16 & $1,8 \%$ \\
ESTJ & 138 & $30,4 \%$ & 127 & $30,1 \%$ & 265 & $30,3 \%$ \\
ESTP & 6 & $1,3 \%$ & 6 & $1,4 \%$ & 12 & $1,4 \%$ \\
INFJ & 15 & $3,3 \%$ & 5 & $1,2 \%$ & 20 & $2,3 \%$ \\
INFP & 1 &, $2 \%$ & 2 &, $5 \%$ & 3 &, $3 \%$ \\
INTJ & 4 &, $9 \%$ & 10 & $2,4 \%$ & 14 & $1,6 \%$ \\
INTP & 0 &, $0 \%$ & 2 &, $5 \%$ & 2 &, $2 \%$ \\
ISFJ & 16 & $3,5 \%$ & 7 & $1,7 \%$ & 23 & $2,6 \%$ \\
ISFP & 3 &, $7 \%$ & 0 &, $0 \%$ & 3 &, $3 \%$ \\
ISTJ & 17 & $3,7 \%$ & 31 & $7,3 \%$ & 48 & $5,5 \%$ \\
ISTP & 0 &, $0 \%$ & 1 &, $2 \%$ & 1 &, $1 \%$ \\
Total & 454 & $100,0 \%$ & 422 & $100,0 \%$ & 876 & $100,0 \%$ \\
\hline
\end{tabular}

Quadro 19 - Tabela Cruzada: 16 tipos vs. Sexo

\section{Chi-Square Tests}

\begin{tabular}{|l|r|r|r|}
\hline & Value & df & \multicolumn{1}{|c|}{$\begin{array}{c}\text { Asymp. Sig. } \\
\text { (2-sided) }\end{array}$} \\
\hline Pearson Chi-Square & 45,919 & 15 &, 000 \\
$N$ of Valid Cases & 876 & & \\
\hline
\end{tabular}

Quadro 20 - Teste Qui-Quadrado: 16 tipos vs. Sexo

Teste qui-quadrado: Há evidências que permitem rejeitar a hipótese nula de não associação das variáveis, ou seja, as evidências indicam a associação das variáveis. Como exemplo, 19,2\% dos homens têm perfil ENTJ (variação dos racionais), enquanto $11,7 \%$ das mulheres têm esse mesmo perfil. Por outro lado, 
18,5\% das mulheres têm perfil ESFJ, enquanto apenas 10,7\% dos homens têm esse mesmo perfil.

- As Dimensões de Temperamentos vs. Sexo

Extroversão / Introversão:

\begin{tabular}{|c|r|r|r|r|r|r|}
\hline \multirow{2}{*}{} & \multicolumn{4}{|c|}{ Sexo } & \multirow{2}{*}{} \\
\cline { 2 - 6 } & \multicolumn{2}{|c|}{ Mulheres } & \multicolumn{2}{c|}{ Homens } & \multicolumn{2}{c|}{ Total } \\
\cline { 2 - 7 } & Qtde & \multicolumn{1}{c|}{$\%$} & \multicolumn{1}{c|}{ Qtde } & \multicolumn{1}{c|}{$\%$} & Qtde & \multicolumn{1}{c|}{$\%$} \\
\hline Extroversão & 398 & $87,7 \%$ & 364 & $86,3 \%$ & 762 & $87,0 \%$ \\
Introversão & 56 & $12,3 \%$ & 58 & $13,7 \%$ & 114 & $13,0 \%$ \\
Total & 454 & $100 \%$ & 422 & $100 \%$ & 876 & $100 \%$ \\
\hline
\end{tabular}

Quadro 21 - Tabela Cruzada: Extroversão/Introversão vs. Sexo

Chi-Square Tests

\begin{tabular}{|c|c|c|c|}
\hline & Value & $d f$ & $\begin{array}{l}\text { Asymp. Sig. } \\
\text { (2-sided) }\end{array}$ \\
\hline Pearson Chi-Square &, 384 & 1 &, 536 \\
\hline $\mathrm{N}$ of Valid Cases & 876 & & \\
\hline
\end{tabular}

Quadro 22 - Teste Qui-Quadrado: Extroversão/Introversão vs. Sexo

Teste Qui-Quadrado: Não há evidências que permitam rejeitar a hipótese nula de não associação das variáveis, ou seja, as evidências indicam a independência das variáveis. 
Intuição / Sensação:

\begin{tabular}{|c|c|c|c|c|c|c|}
\hline \multirow{2}{*}{} & \multicolumn{4}{|c|}{ Sexo } & \multicolumn{2}{c|}{} \\
\cline { 2 - 7 } & \multicolumn{2}{|c|}{ Mulheres } & \multicolumn{2}{c|}{ Homens } & \multicolumn{2}{c|}{ Total } \\
\cline { 2 - 7 } & Qtde & \multicolumn{1}{|c|}{$\%$} & Qtde & \multicolumn{1}{c|}{$\%$} & Qtde & $\%$ \\
\hline Intuição & 183 & $40,3 \%$ & 196 & $46,4 \%$ & 379 & $43,3 \%$ \\
Sensação & 271 & $59,7 \%$ & 226 & $53,6 \%$ & 497 & $56,7 \%$ \\
Total & 454 & $100,0 \%$ & 422 & $100,0 \%$ & 876 & $100,0 \%$ \\
\hline
\end{tabular}

Quadro 23 - Tabela Cruzada Intuição / Sensação vs. Sexo

Chi-Square Tests

\begin{tabular}{|c|c|c|c|}
\hline & Value & df & $\begin{array}{l}\text { Asymp. Sig. } \\
\text { (2-sided) }\end{array}$ \\
\hline $\begin{array}{l}\text { Pearson Chi-Square } \\
\mathrm{N} \text { of Valid Cases }\end{array}$ & $\begin{array}{r}3,356 \\
876\end{array}$ & 1 & ,067 \\
\hline
\end{tabular}

Quadro 24 - Teste Qui-Quadrado: Intuição/Sensação vs. Sexo

Teste Qui-Quadrado: Não há evidências que permitam rejeitar a hipótese nula de não associação das variáveis, ou seja, as evidências indicam a independência das variáveis.

\section{Sentimento / Pensamento:}

\begin{tabular}{|c|c|c|c|c|c|c|}
\hline \multirow{2}{*}{} & \multicolumn{4}{|c|}{ Sexo } & \multicolumn{2}{c|}{} \\
\cline { 2 - 7 } & \multicolumn{2}{|c|}{ Mulheres } & \multicolumn{2}{c|}{ Homens } & \multicolumn{2}{c|}{ Total } \\
\cline { 2 - 7 } & Qtde & $\%$ & Qtde & $\%$ & Qtde & \multicolumn{1}{c|}{$\%$} \\
\hline Sentimento & 232 & $51,1 \%$ & 152 & $36,0 \%$ & 384 & $43,8 \%$ \\
Pensamento & 222 & $48,9 \%$ & 270 & $64,0 \%$ & 492 & $56,2 \%$ \\
Total & 454 & $100,0 \%$ & 422 & $100,0 \%$ & 876 & $100,0 \%$ \\
\hline
\end{tabular}


Quadro 25 - Tabela Cruzada: Sentimento/Pensamento vs. Sexo

Chi-Square Tests

\begin{tabular}{|c|c|c|c|}
\hline & Value & $\mathrm{df}$ & $\begin{array}{l}\text { Asymp. Sig. } \\
\text { (2-sided) }\end{array}$ \\
\hline $\begin{array}{l}\text { Pearson Chi-Square } \\
\mathrm{N} \text { of Valid Cases }\end{array}$ & $\begin{array}{r}20,208 \\
876\end{array}$ & 1 & ,000 \\
\hline
\end{tabular}

Quadro 26 - Teste Qui-Quadrado: Sentimento/Pensamento vs. Sexo

Teste qui-quadrado: Há evidências que permitem rejeitar a hipótese nula de não associação das variáveis, ou seja, as evidências indicam a associação das variáveis. Neste caso, os homens estão mais concentrados no perfil Pensamento e as mulheres estão mais concentradas no perfil Sentimento.

A dependência entre as variáveis acima confirma o teste anterior de que há evidências de associação entre os 4 Temperamentos e suas 16 variações com o sexo. Assim sendo, é através das funções Sentimento - Pensamento que a classificação dos tipos psicológicos difere entre homens e mulheres.

Julgamento / Percepção:

\begin{tabular}{|c|r|r|r|r|r|r|}
\hline \multirow{2}{*}{} & \multicolumn{4}{|c|}{ Sexo } & \multirow{2}{*}{} \\
\cline { 2 - 7 } & \multicolumn{2}{|c|}{ Mulheres } & \multicolumn{2}{c|}{ Homens } & \multicolumn{2}{c|}{ Total } \\
\cline { 2 - 7 } & \multicolumn{1}{|c|}{ Qtde } & \multicolumn{1}{|c|}{ Qtde } & \multicolumn{1}{c|}{$\%$} & Qtde & \multicolumn{1}{c|}{$\%$} \\
\hline Julgamento & 397 & $87,4 \%$ & 366 & $86,7 \%$ & 763 & $87,1 \%$ \\
Percepção & 57 & $12,6 \%$ & 56 & $13,3 \%$ & 113 & $12,9 \%$ \\
Total & 454 & $100,0 \%$ & 422 & $100,0 \%$ & 876 & $100,0 \%$ \\
\hline
\end{tabular}

Quadro 27 - Tabela Cruzada: Julgamento/Percepção vs. Sexo 
Chi-Square Tests

\begin{tabular}{|c|c|c|c|}
\hline & Value & df & $\begin{array}{l}\text { Asymp. Sig. } \\
\text { (2-sided) }\end{array}$ \\
\hline $\begin{array}{l}\text { Pearson Chi-Square } \\
\mathrm{N} \text { of Valid Cases }\end{array}$ & $\begin{array}{l}.100 \\
876\end{array}$ & 1 & ,752 \\
\hline
\end{tabular}

Quadro 28 - Teste Qui-Quadrado: Julgamento/Percepção vs. Sexo

Teste qui-quadrado: Não há evidências que permitam rejeitar a hipótese nula de não associação das variáveis, ou seja, as evidências indicam a independência das variáveis. 


\subsubsection{Faixa Etária vs. Perfil Psicológico}

- Os 4 Temperamentos vs. Faixa Etária

\begin{tabular}{|c|c|c|c|c|c|c|c|c|c|c|}
\hline & \multicolumn{8}{|c|}{ Faixa Etária } & \multirow{2}{*}{\multicolumn{2}{|c|}{ Total }} \\
\hline & \multicolumn{2}{|c|}{$<=22$} & \multicolumn{2}{|c|}{$23-24$} & \multicolumn{2}{|c|}{$25-26$} & \multicolumn{2}{|c|}{$27+$} & & \\
\hline & Qtde & $\%$ & Qtde & $\%$ & Qtde & $\%$ & Qtde & $\%$ & Qtde & $\%$ \\
\hline Rational & 49 & $21,5 \%$ & 54 & $20,8 \%$ & 36 & $19,0 \%$ & 27 & $13,5 \%$ & 166 & $18,9 \%$ \\
\hline Idealist & 70 & $30,7 \%$ & 62 & $23,9 \%$ & 46 & $24,3 \%$ & 35 & $17,5 \%$ & 213 & $24,3 \%$ \\
\hline Artisan & 13 & $5,7 \%$ & 3 & $1,2 \%$ & 8 & $4,2 \%$ & 8 & $4,0 \%$ & 32 & $3,7 \%$ \\
\hline Guardian & 96 & $42,1 \%$ & 140 & $54,1 \%$ & 99 & $52,4 \%$ & 130 & $65,0 \%$ & 465 & $53,1 \%$ \\
\hline Total & 228 & $100 \%$ & 259 & $100 \%$ & 189 & $100 \%$ & 200 & $100 \%$ & 876 & $100 \%$ \\
\hline
\end{tabular}

Quadro 29 - Tabela Cruzada: Os 4 Temperamentos vs. Faixa Etária

Chi-Square Tests

\begin{tabular}{|c|c|c|c|}
\hline & Value & df & $\begin{array}{l}\text { Asymp. Sig. } \\
\text { (2-sided) }\end{array}$ \\
\hline $\begin{array}{l}\text { Pearson Chi-Square } \\
\mathrm{N} \text { of Valid Cases }\end{array}$ & $\begin{array}{r}29,929 \\
876\end{array}$ & 9 & ,000 \\
\hline
\end{tabular}

Quadro 30 - Teste Qui-Quadrado: Os 4 Temperamentos vs. Faixa Etária

Teste Qui-Quadrado: Há evidências que permitem rejeitar a hipótese nula de não associação das variáveis, ou seja, as evidências indicam a associação das variáveis. Os mais "maduros", considerando que a amostra é de jovens, concentramse mais no perfil Guardians, reduzindo os percentuais de Idealists e Rationals. 
- Os 16 tipos vs. Faixa Etária

\begin{tabular}{|c|c|c|c|c|c|c|c|c|c|c|}
\hline & \multicolumn{8}{|c|}{ Faixa Etária } & \multirow{2}{*}{\multicolumn{2}{|c|}{ Total }} \\
\hline & \multicolumn{2}{|c|}{$<=22$} & \multicolumn{2}{|c|}{$23-24$} & \multicolumn{2}{|c|}{$25-26$} & \multicolumn{2}{|c|}{$27+$} & & \\
\hline & Qtde & $\%$ & Qtde & $\%$ & Qtde & $\%$ & Qtde & $\%$ & Qtde & $\%$ \\
\hline ENFJ & 43 & $18,9 \%$ & 32 & $12,4 \%$ & 33 & $17,5 \%$ & 22 & $11,0 \%$ & 130 & $14,8 \%$ \\
\hline ENFP & 21 & $9,2 \%$ & 21 & $8,1 \%$ & 8 & $4,2 \%$ & 10 & $5,0 \%$ & 60 & $6,8 \%$ \\
\hline ENTJ & 40 & $17,5 \%$ & 43 & $16,6 \%$ & 30 & $15,9 \%$ & 21 & $10,5 \%$ & 134 & $15,3 \%$ \\
\hline ENTP & 4 & $1,8 \%$ & 6 & $2,3 \%$ & 4 & $2,1 \%$ & 2 & $1,0 \%$ & 16 & $1,8 \%$ \\
\hline ESFJ & 29 & $12,7 \%$ & 44 & $17,0 \%$ & 25 & $13,2 \%$ & 31 & $15,5 \%$ & 129 & $14,7 \%$ \\
\hline ESFP & 8 & $3,5 \%$ & 2 & ,8\% & 3 & $1,6 \%$ & 3 & $1,5 \%$ & 16 & $1,8 \%$ \\
\hline ESTJ & 55 & $24,1 \%$ & 78 & $30,1 \%$ & 52 & $27,5 \%$ & 80 & $40,0 \%$ & 265 & $30,3 \%$ \\
\hline ESTP & 3 & $1,3 \%$ & 0 &, $0 \%$ & 4 & $2,1 \%$ & 5 & $2,5 \%$ & 12 & $1,4 \%$ \\
\hline INFJ & 5 & $2,2 \%$ & 9 & $3,5 \%$ & 4 & $2,1 \%$ & 2 & $1,0 \%$ & 20 & $2,3 \%$ \\
\hline INFP & 1 &, $4 \%$ & 0 &, $0 \%$ & 1 &, $5 \%$ & 1 &, $5 \%$ & 3 & ,3\% \\
\hline INTJ & 3 & $1,3 \%$ & 5 & $1,9 \%$ & 2 & $1,1 \%$ & 4 & $2,0 \%$ & 14 & $1,6 \%$ \\
\hline INTP & 2 &, $9 \%$ & 0 &, $0 \%$ & 0 &, $0 \%$ & 0 &, $0 \%$ & 2 &, $2 \%$ \\
\hline ISFJ & 4 & $1,8 \%$ & 6 & $2,3 \%$ & 8 & $4,2 \%$ & 5 & $2,5 \%$ & 23 & $2,6 \%$ \\
\hline ISFP & 2 &, $9 \%$ & 0 & $0 \%$ & 1 &, $5 \%$ & 0 &, $0 \%$ & 3 & ,3\% \\
\hline ISTJ & 8 & $3,5 \%$ & 12 & $4,6 \%$ & 14 & $7,4 \%$ & 14 & $7,0 \%$ & 48 & $5,5 \%$ \\
\hline ISTP & 0 &, $0 \%$ & 1 & ,4\% & 0 &, $0 \%$ & 0 &, $0 \%$ & 1 & ,1\% \\
\hline Total & 228 & $100 \%$ & 259 & $100 \%$ & 189 & $100 \%$ & 200 & $100 \%$ & 876 & $100 \%$ \\
\hline
\end{tabular}

Quadro 31 - Tabela Cruzada: 16 tipos vs. Faixa Etária

Chi-Square Tests

\begin{tabular}{|l|r|r|r|}
\hline & Value & df & $\begin{array}{c}\text { Asymp. Sig. } \\
\text { (2-sided) }\end{array}$ \\
\hline Pearson Chi-Square & 63,635 & 45 &, 035 \\
N of Valid Cases & 876 & & \\
\hline
\end{tabular}

Quadro 32 - Teste Qui-Quadrado: 16 tipos vs. Faixa Etária

Teste Qui-Quadrado: Há evidências que permitem rejeitar a hipótese nula de não associação das variáveis, ou seja, as evidências indicam a associação das variáveis. Confirmando o teste anterior, há uma tendência a aumentar a concentração no perfil ESTJ para os mais maduros. Reduzindo, principalmente, o perfil ENTJ e ENFJ. 
- As Dimensões dos Temperamentos vs. Faixa Etária

\section{Extroversão / Introversão}

\begin{tabular}{|c|c|c|c|c|c|c|c|c|c|c|}
\hline & \multicolumn{8}{|c|}{ Faixa Etária } & \multirow{2}{*}{\multicolumn{2}{|c|}{ Total }} \\
\hline & \multicolumn{2}{|c|}{$<=22$} & \multicolumn{2}{|c|}{$23-24$} & \multicolumn{2}{|c|}{$25-26$} & \multicolumn{2}{|c|}{$27+$} & & \\
\hline & Qtde & $\%$ & Qtde & $\%$ & Qtde & $\%$ & Qtde & $\%$ & Qtde & $\%$ \\
\hline Extroversão & 203 & $89,0 \%$ & 226 & $87,3 \%$ & 159 & $84,1 \%$ & 174 & $87,0 \%$ & 762 & $87,0 \%$ \\
\hline Introversão & 25 & $11,0 \%$ & 33 & $12,7 \%$ & 30 & $15,9 \%$ & 26 & $13,0 \%$ & 114 & $13,0 \%$ \\
\hline Total & 228 & $100,0 \%$ & 259 & $100,0 \%$ & 189 & $100,0 \%$ & 200 & $100,0 \%$ & 876 & $100,0 \%$ \\
\hline
\end{tabular}

Quadro 33 - Tabela Cruzada: Extroversão/Introversão vs. Faixa Etária

Chi-Square Tests

\begin{tabular}{|c|c|c|c|}
\hline & Value & $\mathrm{df}$ & $\begin{array}{l}\text { Asymp. Sig. } \\
\text { (2-sided) }\end{array}$ \\
\hline Pearson Chi-Square & 2,227 & $\overline{3}$ & ,527 \\
\hline
\end{tabular}

Quadro 34 - Extroversão/Introversão vs. Faixa Etária

Teste Qui-Quadrado: Não há evidências que permitam rejeitar a hipótese nula de não associação das variáveis, ou seja, as evidências indicam a independência das variáveis. 
Sensação / Intuição

\begin{tabular}{|c|c|c|c|c|c|c|c|c|c|c|}
\hline & \multicolumn{8}{|c|}{ Faixa Etária } & \multirow{2}{*}{\multicolumn{2}{|c|}{ Total }} \\
\hline & \multicolumn{2}{|c|}{$<=22$} & \multicolumn{2}{|c|}{$23-24$} & \multicolumn{2}{|c|}{$25-26$} & \multicolumn{2}{|c|}{$27+$} & & \\
\hline & Qtde & $\%$ & Qtde & $\%$ & Qtde & $\%$ & Qtde & $\%$ & Qtde & $\%$ \\
\hline Intuição & 119 & $52,2 \%$ & 116 & $44,8 \%$ & 82 & $43,4 \%$ & 62 & $31,0 \%$ & 379 & $43,3 \%$ \\
\hline Sensação & 109 & $47,8 \%$ & 143 & $55,2 \%$ & 107 & $56,6 \%$ & 138 & $69,0 \%$ & 497 & $56,7 \%$ \\
\hline Total & 228 & $100,0 \%$ & 259 & $100,0 \%$ & 189 & $100,0 \%$ & 200 & $100,0 \%$ & 876 & $100,0 \%$ \\
\hline
\end{tabular}

Quadro 35 - Tabela Cruzada: Sensação/Intuição vs. Faixa Etária

Chi-Square Tests

\begin{tabular}{|c|c|c|c|}
\hline Statistics & Value & $\mathrm{df}$ & $\begin{array}{l}\text { Asymp. Sig. } \\
\text { (2-sided) }\end{array}$ \\
\hline Pearson Chi-Square & 19,906 & 3 & ,000 \\
\hline
\end{tabular}

Quadro 36 - Teste Qui-Quadrado: Sensação/Intuição vs. Faixa Etária

Teste Qui-Quadrado: Há evidências que permitem rejeitar a hipótese nula de não associação das variáveis, ou seja, as evidências indicam a associação das variáveis. Existe uma relação entre a faixa etária da amostra observada e as funções Sensação / Intuição.

À medida que aumenta a faixa etária, há maior incidência do perfil Sensação. Pessoas deste perfil são mais detalhistas, extraem informações através dos 5 sentidos e observam aquilo que é real. Podendo indicar, assim, que as pessoas evoluem no sentido "observador" à medida que ficam mais maduras, explorando mais a forma de trabalhar as informações adquiridas. 
Sentimento / Pensamento

\begin{tabular}{|c|r|r|r|r|r|r|r|r|r|r|r|}
\hline \multirow{4}{*}{} & \multicolumn{9}{|c|}{ Faixa Etária } & \multicolumn{2}{c|}{} \\
\cline { 2 - 11 } & \multicolumn{2}{|c|}{$<=22$} & \multicolumn{2}{|c|}{$23-24$} & \multicolumn{2}{|c|}{$25-26$} & \multicolumn{2}{c|}{$27+$} & \multicolumn{2}{c|}{ Total } \\
\cline { 2 - 11 } & Qtde & $\%$ & Qtde & $\%$ & Qtde & $\%$ & Qtde & $\%$ & Qtde & $\%$ \\
\hline Sentimento & 113 & $49,6 \%$ & 114 & $44,0 \%$ & 83 & $43,9 \%$ & 74 & $37,0 \%$ & 384 & $43,8 \%$ \\
Pensamento & 115 & $50,4 \%$ & 145 & $56,0 \%$ & 106 & $56,1 \%$ & 126 & $63,0 \%$ & 492 & $56,2 \%$ \\
Total & 228 & $100 \%$ & 259 & $100 \%$ & 189 & $100 \%$ & 200 & $100 \%$ & 876 & $100 \%$ \\
\hline
\end{tabular}

Quadro 37 - Tabela Cruzada: Sentimento/Pensamento vs. Faixa Etária

Chi-Square Tests

\begin{tabular}{|c|c|c|c|}
\hline & Value & $\mathrm{df}$ & $\begin{array}{c}\text { Asymp. Sig. } \\
\text { (2-sided) }\end{array}$ \\
\hline Pearson Chi-Square & 6,836 & 3 & ,077 \\
\hline $\mathrm{N}$ of Valid Cases & 876 & & \\
\hline
\end{tabular}

Quadro 38 - Teste Qui-Quadrado: Sentimento/Pensamento vs. Faixa Etária

Teste Qui-Quadrado: Não há evidências que permitam rejeitar a hipótese nula de não associação das variáveis, ou seja, as evidências indicam a independência das variáveis.

Julgamento / Percepção

\begin{tabular}{|c|c|c|c|c|c|c|c|c|c|c|}
\hline & \multicolumn{8}{|c|}{ Faixa Etária } & \multirow{2}{*}{\multicolumn{2}{|c|}{ Total }} \\
\hline & \multicolumn{2}{|c|}{$<=22$} & \multicolumn{2}{|c|}{$23-24$} & \multicolumn{2}{|c|}{$25-26$} & \multicolumn{2}{|c|}{$27+$} & & \\
\hline & Qtde & $\%$ & Qtde & $\%$ & Qtde & $\%$ & Qtde & $\%$ & Qtde & $\%$ \\
\hline Julgamento & 187 & $82,0 \%$ & 229 & $88,4 \%$ & 168 & $88,9 \%$ & 179 & $89,5 \%$ & 763 & $87,1 \%$ \\
\hline Percepção & 41 & $18,0 \%$ & 30 & $11,6 \%$ & 21 & $11,1 \%$ & 21 & $10,5 \%$ & 113 & $12,9 \%$ \\
\hline Total & 228 & $100 \%$ & 259 & $100 \%$ & 189 & $100 \%$ & 200 & $100 \%$ & 876 & $100 \%$ \\
\hline
\end{tabular}

Quadro 39 - Tabela Cruzada: Julgamento/Percepção vs. Faixa Etária 
Chi-Square Tests

\begin{tabular}{|c|c|c|c|}
\hline & Value & $\mathrm{df}$ & $\begin{array}{l}\text { Asymp. Sig. } \\
\text { (2-sided) }\end{array}$ \\
\hline $\begin{array}{l}\text { Pearson Chi-Square } \\
\mathrm{N} \text { of Valid Cases }\end{array}$ & $\begin{array}{r}7,205 \\
876\end{array}$ & 3 & ,066 \\
\hline
\end{tabular}

Quadro 40 - Teste Qui-Quadrado: Julgamento/Percepção vs. Faixa Etária

Teste Qui-Quadrado: Não há evidências que permitam rejeitar a hipótese nula de não associação das variáveis, ou seja, as evidências indicam a independência das variáveis. 


\subsubsection{Perfil Psicológico vs. Perfil de Utilização de Produtos Bancários}

Neste item, são analisadas as associações entre os tipos psicológicos e suas variações, incluindo as variações das dimensões dos temperamentos com a utilização de produtos bancários. Parte-se do pressuposto que todos os observados são correntistas, portanto, não está incluída a variável de relacionamento com o banco que indica a posse de conta corrente.

\subsubsection{Capitalização}

Os 4 temperamentos vs. Título de Capitalização:

\begin{tabular}{|c|r|c|r|r|r|r|}
\hline \multirow{2}{*}{} & \multicolumn{3}{|c|}{ Possui Capitalização } & \multicolumn{2}{|c|}{} \\
\cline { 2 - 7 } & \multicolumn{2}{|c|}{ Não } & \multicolumn{2}{c|}{ Sim } & \multicolumn{2}{c|}{ Total } \\
\cline { 2 - 7 } & Qtde & \multicolumn{1}{|c}{$\%$} & \multicolumn{1}{c|}{ Qtde } & \multicolumn{1}{c|}{$\%$} & Qtde & $\%$ \\
\hline Rational & 139 & $83,7 \%$ & 27 & $16,3 \%$ & 166 & $100 \%$ \\
Idealist & 180 & $84,5 \%$ & 33 & $15,5 \%$ & 213 & $100 \%$ \\
Artisan & 25 & $78,1 \%$ & 7 & $21,9 \%$ & 32 & $100 \%$ \\
Guardian & 396 & $85,2 \%$ & 69 & $14,8 \%$ & 465 & $100 \%$ \\
Total & 740 & $84,5 \%$ & 136 & $15,5 \%$ & 876 & $100 \%$ \\
\hline
\end{tabular}

Quadro 41 - Tabela Cruzada: Os 4 Temperamentos vs. Capitalização

Chi-Square Tests

\begin{tabular}{|l|r|r|c|}
\hline & Value & df & $\begin{array}{c}\text { Asymp. Sig. } \\
\text { (2-sided) }\end{array}$ \\
\hline Pearson Chi-Square & 1,220 & & 3 \\
N of Valid Cases & 876 & &, 748 \\
\hline
\end{tabular}

Quadro 42 - Teste Qui-Quadrado: Os 4 Temperamentos vs. Capitalização 
Teste Qui-Quadrado: Não há evidências que permitam rejeitar a hipótese nula de não associação das variáveis, ou seja, as evidências indicam a independência das variáveis.

- Os 16 tipos vs. Título de Capitalização:

\begin{tabular}{|c|r|r|r|r|r|r|}
\hline & \multicolumn{4}{|c|}{ Possui Capitalização } & \multicolumn{2}{|c|}{} \\
\cline { 2 - 5 } & \multicolumn{2}{|c|}{ Não } & \multicolumn{2}{|c|}{ Sim } & \multicolumn{2}{c|}{ Total } \\
\cline { 2 - 5 } & \multicolumn{1}{|c|}{ Qtde } & \multicolumn{1}{c|}{$\%$} & Qtde & \multicolumn{1}{c|}{$\%$} & Qtde & \multicolumn{1}{c|}{$\%$} \\
\hline ENFJ & 109 & $83,8 \%$ & 21 & $16,2 \%$ & 130 & $100,0 \%$ \\
ENFP & 50 & $83,3 \%$ & 10 & $16,7 \%$ & 60 & $100,0 \%$ \\
ENTJ & 110 & $82,1 \%$ & 24 & $17,9 \%$ & 134 & $100,0 \%$ \\
ENTP & 13 & $81,3 \%$ & 3 & $18,8 \%$ & 16 & $100,0 \%$ \\
ESFJ & 113 & $87,6 \%$ & 16 & $12,4 \%$ & 129 & $100,0 \%$ \\
ESFP & 12 & $75,0 \%$ & 4 & $25,0 \%$ & 16 & $100,0 \%$ \\
ESTJ & 218 & $82,3 \%$ & 47 & $17,7 \%$ & 265 & $100,0 \%$ \\
ESTP & 10 & $83,3 \%$ & 2 & $16,7 \%$ & 12 & $100,0 \%$ \\
INFJ & 19 & $95,0 \%$ & 1 & $5,0 \%$ & 20 & $100,0 \%$ \\
INFP & 2 & $66,7 \%$ & 1 & $33,3 \%$ & 3 & $100,0 \%$ \\
INTJ & 14 & $100,0 \%$ & 0 &, $0 \%$ & 14 & $100,0 \%$ \\
INTP & 2 & $100,0 \%$ & 0 &, $0 \%$ & 2 & $100,0 \%$ \\
ISFJ & 22 & $95,7 \%$ & 1 & $4,3 \%$ & 23 & $100,0 \%$ \\
ISFP & 2 & $66,7 \%$ & 1 & $33,3 \%$ & 3 & $100,0 \%$ \\
ISTJ & 43 & $89,6 \%$ & 5 & $10,4 \%$ & 48 & $100,0 \%$ \\
ISTP & 1 & $100,0 \%$ & 0 &, $0 \%$ & 1 & $100,0 \%$ \\
Total & 740 & $84,5 \%$ & 136 & $15,5 \%$ & 876 & $100,0 \%$ \\
\hline
\end{tabular}

Quadro 43 - Tabela Cruzada: 16 tipos vs. Capitalização

Chi-Square Tests

\begin{tabular}{|l|r|r|c|}
\hline & Value & df & $\begin{array}{c}\text { Asymp. Sig. } \\
\text { (2-sided) }\end{array}$ \\
\hline Pearson Chi-Square & $\begin{array}{r}13,271 \\
\text { N of Valid Cases }\end{array}$ & 15 &, 581 \\
\hline
\end{tabular}

Quadro 44 - Teste Qui-Quadrado: 16 tipos vs. Capitalização 
Teste Qui-Quadrado: Não há evidências que permitam rejeitar a hipótese nula de não associação das variáveis, ou seja, as evidências indicam a independência das variáveis

As Dimensões dos Temperamentos vs. Capitalização:

\section{Extroversão / Introversão}

\begin{tabular}{|c|c|c|r|r|r|r|}
\hline \multirow{2}{*}{} & \multicolumn{3}{|c|}{ Possui Capitalização } & \multicolumn{2}{c|}{} \\
\cline { 2 - 5 } & \multicolumn{2}{|c|}{ Não } & \multicolumn{2}{c|}{ Sim } & \multicolumn{2}{c|}{ Total } \\
\cline { 2 - 7 } & Qtde & \multicolumn{1}{c|}{$\%$} & \multicolumn{1}{c|}{ Qtde } & \multicolumn{1}{c|}{ Qtde } & $\%$ \\
\hline Extroversão & 635 & $83,3 \%$ & 127 & $16,7 \%$ & 762 & $100 \%$ \\
Introversão & 105 & $92,1 \%$ & 9 & $7,9 \%$ & 114 & $100 \%$ \\
Total & 740 & $84,5 \%$ & 136 & $15,5 \%$ & 876 & $100 \%$ \\
\hline
\end{tabular}

Quadro 45 - Tabela Cruzada: Extroversão/Introversão vs. Capitalização

Chi-Square Tests

\begin{tabular}{|l|r|r|r|}
\hline & Value & df & $\begin{array}{c}\text { Asymp. Sig. } \\
\text { (2-sided) }\end{array}$ \\
\hline Pearson Chi-Square & 5,818 & & 1 \\
N of Valid Cases & 876 & &, 016 \\
\hline
\end{tabular}

Quadro 46 - Teste Qui-Quadrado: Extroversão/Introversão vs. Capitalização

Teste Qui-Quadrado: Há evidências que permitem rejeitar a hipótese nula de não associação das variáveis, ou seja, as evidências indicam a associação das variáveis. 
Estatisticamente, há evidências de ocorrer uma diferença entre indivíduos extrovertidos e introvertidos quanto à posse de títulos de capitalização. A capitalização é uma economia programada, vinculada a sorteios e, ao final do plano, o cliente receberá o valor pago atualizado monetariamente.

Aqueles indivíduos que possuem títulos estão mais concentrados no perfil Extrovertido do que no perfil Introvertido. 
Sensação / Intuição

\begin{tabular}{|c|c|c|r|r|r|r|}
\hline \multirow{2}{*}{} & \multicolumn{4}{|c|}{ Possui Capitalização } & \multicolumn{2}{c|}{} \\
\cline { 2 - 7 } & \multicolumn{2}{|c|}{ Não } & \multicolumn{2}{c|}{ Sim } & \multicolumn{2}{c|}{ Total } \\
\cline { 2 - 7 } & Qtde & $\%$ & Qtde & $\%$ & Qtde & $\%$ \\
\hline Intuição & 319 & $84,2 \%$ & 60 & $15,8 \%$ & 379 & $100 \%$ \\
Sensação & 421 & $84,7 \%$ & 76 & $15,3 \%$ & 497 & $100 \%$ \\
Total & 740 & $84,5 \%$ & 136 & $15,5 \%$ & 876 & $100 \%$ \\
\hline
\end{tabular}

Quadro 47 - Tabela Cruzada: Sensação/Intuição vs. Capitalização

Chi-Square Tests

\begin{tabular}{|c|c|c|c|}
\hline & Value & df & $\begin{array}{c}\text { Asymp. Sig. } \\
\text { (2-sided) }\end{array}$ \\
\hline Pearson Chi-Square & ,048 & 1 & ,827 \\
\hline $\mathrm{N}$ of Valid Cases & 876 & & \\
\hline
\end{tabular}

Quadro 48 - Teste Qui-Quadrado: Sensação/Intuição vs. Capitalização

Teste Qui-Quadrado: Não há evidências que permitam rejeitar a hipótese nula de não associação das variáveis, ou seja, as evidências indicam a independência das variáveis. 
Sentimento / Pensamento

\begin{tabular}{|c|c|c|r|c|c|c|}
\hline \multirow{2}{*}{} & \multicolumn{4}{|c|}{ Possui Capitalização } & \multirow{2}{*}{} \\
\cline { 2 - 6 } & \multicolumn{2}{|c|}{ Não } & \multicolumn{2}{c|}{ Sim } & \multicolumn{2}{c|}{ Total } \\
\cline { 2 - 7 } & Qtde & \multicolumn{1}{|c}{$\%$} & Qtde & $\%$ & Qtde & $\%$ \\
\hline Sentimento & 329 & $85,7 \%$ & 55 & $14,3 \%$ & 384 & $100 \%$ \\
Pensamento & 411 & $83,5 \%$ & 81 & $16,5 \%$ & 492 & $100 \%$ \\
Total & 740 & $84,5 \%$ & 136 & $15,5 \%$ & 876 & $100 \%$ \\
\hline
\end{tabular}

Quadro 49 - Tabela Cruzada: Sentimento/Pensamento vs. Capitalização

Chi-Square Tests

\begin{tabular}{|c|c|c|c|}
\hline & Value & $\mathrm{df}$ & $\begin{array}{c}\text { Asymp. Sig. } \\
\text { (2-sided) }\end{array}$ \\
\hline Pearson Chi-Square & $\begin{array}{l}753 \\
, 753\end{array}$ & 1 & ,385 \\
\hline $\mathrm{N}$ of Valid Cases & 876 & & \\
\hline
\end{tabular}

Quadro 50 - Teste Qui-Quadrado: Sentimento/Pensamento vs. Capitalização

Teste Qui-Quadrado: Não há evidências que permitam rejeitar a hipótese nula de não associação das variáveis, ou seja, as evidências indicam a independência das variáveis.

\section{Julgamento / Percepção}

\begin{tabular}{|c|r|c|r|c|r|c|}
\hline \multirow{2}{*}{} & \multicolumn{4}{|c|}{ Possui Capitalização } & \multicolumn{2}{c|}{} \\
\cline { 2 - 6 } & \multicolumn{2}{|c|}{ Não } & \multicolumn{2}{c|}{ Sim } & \multicolumn{2}{c|}{ Total } \\
\cline { 2 - 6 } & Count & $\%$ & Count & $\%$ & Count & $\%$ \\
\hline Julgamento & 648 & $84,9 \%$ & 115 & $15,1 \%$ & 763 & $100 \%$ \\
Percepção & 92 & $81,4 \%$ & 21 & $18,6 \%$ & 113 & $100 \%$ \\
Total & 740 & $84,5 \%$ & 136 & $15,5 \%$ & 876 & $100 \%$ \\
\hline
\end{tabular}

Quadro 51 - Tabela Cruzada: Julgamento/Percepção vs. Capitalização 
Chi-Square Tests

\begin{tabular}{|c|c|c|c|}
\hline & Value & $\mathrm{df}$ & $\begin{array}{l}\text { Asymp. Sig. } \\
\text { (2-sided) }\end{array}$ \\
\hline Pearson Chi-Square & ,926 & 1 & ,336 \\
\hline $\mathrm{N}$ of Valid Cases & 876 & & \\
\hline
\end{tabular}

Quadro 52 - Teste Qui-Quadrado: Julgamento/Percepção vs. Capitalização

Teste Qui-Quadrado: Não há evidências que permitam rejeitar a hipótese nula de não associação das variáveis, ou seja, as evidências indicam a independência das variáveis. 


\subsubsection{Cartão de Crédito}

Os 4 Temperamentos vs. Utilização de Cartão de Crédito:

\begin{tabular}{|c|r|c|r|r|r|c|}
\hline \multirow{2}{*}{} & \multicolumn{3}{|c|}{ Utiliza Cartão de Crédito } & \multicolumn{2}{|c|}{} \\
\cline { 2 - 7 } & \multicolumn{2}{|c|}{ Não } & \multicolumn{2}{c|}{ Sim } & \multicolumn{2}{c|}{ Total } \\
\cline { 2 - 6 } & Qtde & \multicolumn{1}{|c}{$\%$} & Qtde & \multicolumn{1}{c|}{$\%$} & Qtde & $\%$ \\
\hline Rational & 31 & $18,7 \%$ & 135 & $81,3 \%$ & 166 & $100,0 \%$ \\
Idealist & 36 & $16,9 \%$ & 177 & $83,1 \%$ & 213 & $100,0 \%$ \\
Artisan & 4 & $12,5 \%$ & 28 & $87,5 \%$ & 32 & $100,0 \%$ \\
Guardian & 75 & $16,1 \%$ & 390 & $83,9 \%$ & 465 & $100,0 \%$ \\
Total & 146 & $16,7 \%$ & 730 & $83,3 \%$ & 876 & $100,0 \%$ \\
\hline
\end{tabular}

Quadro 53 - Tabela Cruzada: Os 4 Temperamentos vs. Cartão de Crédito

Chi-Square Tests

\begin{tabular}{|c|c|c|c|}
\hline & Value & $\mathrm{df}$ & $\begin{array}{l}\text { Asymp. Sig. } \\
\text { (2-sided) }\end{array}$ \\
\hline Pearson Chi-Square & 987 & 3 & ,804 \\
\hline
\end{tabular}

Quadro 54 - Teste Qui-Quadrado: Os 4 Temperamentos vs. Cartão de Crédito

Teste Qui-Quadrado: Não há evidências que permitam rejeitar a hipótese nula de não associação das variáveis, ou seja, as evidências indicam a independência das variáveis. 
Os 16 tipos vs. Utilização de Cartão de Crédito:

\begin{tabular}{|c|c|c|c|c|c|c|}
\hline & \multicolumn{4}{|c|}{ Utiliza Cartão de Crédito } & \multirow{2}{*}{\multicolumn{2}{|c|}{ Total }} \\
\hline & \multicolumn{2}{|c|}{ Não } & \multicolumn{2}{|c|}{ Sim } & & \\
\hline & Qtde & $\%$ & Qtde & $\%$ & Qtde & $\%$ \\
\hline ENFJ & 21 & $16,2 \%$ & 109 & $83,8 \%$ & 130 & $100,0 \%$ \\
\hline ENFP & 10 & $16,7 \%$ & 50 & $83,3 \%$ & 60 & $100,0 \%$ \\
\hline ENTJ & 20 & $14,9 \%$ & 114 & $85,1 \%$ & 134 & $100,0 \%$ \\
\hline ENTP & 5 & $31,3 \%$ & 11 & $68,8 \%$ & 16 & $100,0 \%$ \\
\hline ESFJ & 20 & $15,5 \%$ & 109 & $84,5 \%$ & 129 & $100,0 \%$ \\
\hline ESFP & 1 & $6,3 \%$ & 15 & $93,8 \%$ & 16 & $100,0 \%$ \\
\hline ESTJ & 39 & $14,7 \%$ & 226 & $85,3 \%$ & 265 & $100,0 \%$ \\
\hline ESTP & 2 & $16,7 \%$ & 10 & $83,3 \%$ & 12 & $100,0 \%$ \\
\hline INFJ & 2 & $10,0 \%$ & 18 & $90,0 \%$ & 20 & $100,0 \%$ \\
\hline INFP & 3 & $100,0 \%$ & 0 &, $0 \%$ & 3 & $100,0 \%$ \\
\hline INTJ & 5 & $35,7 \%$ & 9 & $64,3 \%$ & 14 & $100,0 \%$ \\
\hline INTP & 1 & $50,0 \%$ & 1 & $50,0 \%$ & 2 & $100,0 \%$ \\
\hline ISFJ & 6 & $26,1 \%$ & 17 & $73,9 \%$ & 23 & $100,0 \%$ \\
\hline ISFP & 1 & $33,3 \%$ & 2 & $66,7 \%$ & 3 & $100,0 \%$ \\
\hline ISTJ & 10 & $20,8 \%$ & 38 & $79,2 \%$ & 48 & $100,0 \%$ \\
\hline ISTP & 0 &, $0 \%$ & 1 & $100,0 \%$ & 1 & $100,0 \%$ \\
\hline Total & 146 & $16,7 \%$ & 730 & $83,3 \%$ & 876 & $100,0 \%$ \\
\hline
\end{tabular}

Quadro 55 - Tabela Cruzada: 16 tipos vs. Cartão de Crédito

Chi-Square Tests

\begin{tabular}{|l|r|r|r|}
\hline & Value & df & \multicolumn{1}{|c|}{$\begin{array}{c}\text { Asymp. Sig. } \\
\text { (2-sided) }\end{array}$} \\
\hline Pearson Chi-Square & 28,635 & 15 &, 018 \\
N of Valid Cases & 876 & & \\
\hline
\end{tabular}

Quadro 56 - Teste Qui-Quadrado: 16 tipos vs. Cartão de Crédito

Teste Qui-Quadrado: Não há evidências que permitam rejeitar a hipótese nula de não associação das variáveis, ou seja, as evidências indicam a independência das variáveis. 
As Dimensões de Temperamento vs. Utilização de Cartão de Crédito

\section{Extrovertido / Introvertido}

\begin{tabular}{|c|r|c|r|r|r|r|}
\hline \multirow{2}{*}{} & \multicolumn{3}{|c|}{ Utiliza Cartão de Crédito } & \multirow{2}{*}{} \\
\cline { 2 - 7 } & \multicolumn{2}{|c|}{ Não } & \multicolumn{2}{c|}{ Sim } & \multicolumn{2}{c|}{ Total } \\
\cline { 2 - 7 } & \multicolumn{1}{|c|}{ Qtde } & \multicolumn{1}{|c|}{$\%$} & \multicolumn{1}{c|}{ Qtde } & $\%$ & Qtde & $\%$ \\
\hline Extroversão & 118 & $15,5 \%$ & 644 & $84,5 \%$ & 762 & $100 \%$ \\
Introversão & 28 & $24,6 \%$ & 86 & $75,4 \%$ & 114 & $100 \%$ \\
Total & 146 & $16,7 \%$ & 730 & $83,3 \%$ & 876 & $100 \%$ \\
\hline
\end{tabular}

Quadro 57 - Tabela Cruzada: Extroversão/Introversão vs. Cartão de Crédito

Chi-Square Tests

\begin{tabular}{|c|c|c|c|}
\hline & Value & df & $\begin{array}{l}\text { Asymp. Sig. } \\
\text { (2-sided) }\end{array}$ \\
\hline $\begin{array}{l}\text { Pearson Chi-Square } \\
\mathrm{N} \text { of Valid Cases }\end{array}$ & $\begin{array}{r}5,881 \\
876\end{array}$ & 1 & 015, \\
\hline
\end{tabular}

Quadro 58 - Teste Qui-Quadrado: Extroversão/Introversão vs. Cartão de Crédito

Teste Qui-Quadrado:. Há evidências que permitem rejeitar a hipótese nula de não associação das variáveis, ou seja, as evidências indicam a associação das variáveis. Os extrovertidos apresentam evidências de maior utilização de cartão de crédito do que os introvertidos. 
Sensação / Intuição

\begin{tabular}{|c|r|c|c|c|c|c|}
\hline \multirow{2}{*}{} & \multicolumn{3}{|c|}{ Utiliza Cartão de Crédito } & \multirow{2}{*}{} \\
\cline { 2 - 7 } & \multicolumn{2}{|c|}{ Não } & \multicolumn{2}{c|}{ Sim } & \multicolumn{2}{c|}{ Total } \\
\cline { 2 - 7 } & Qtde & \multicolumn{1}{|c|}{$\%$} & Qtde & $\%$ & Qtde & $\%$ \\
\hline Intuição & 67 & $17,7 \%$ & 312 & $82,3 \%$ & 379 & $100,0 \%$ \\
Sensação & 79 & $15,9 \%$ & 418 & $84,1 \%$ & 497 & $100,0 \%$ \\
Total & 146 & $16,7 \%$ & 730 & $83,3 \%$ & 876 & $100,0 \%$ \\
\hline
\end{tabular}

Quadro 59 - Tabela Cruzada: Sensação/Intuição vs. Cartão de Crédito

Chi-Square Tests

\begin{tabular}{|c|c|c|c|}
\hline & Value & df & $\begin{array}{l}\text { Asymp. Sig. } \\
\text { (2-sided) }\end{array}$ \\
\hline Pearson Chi-Square & ,492 & 1 &, 483 \\
\hline $\mathrm{N}$ of Valid Cases & 876 & & \\
\hline
\end{tabular}

Quadro 60 - Teste Qui-Quadrado: Sensação/Intuição vs. Cartão de Crédito

Teste Qui-Quadrado: Não há evidências que permitam rejeitar a hipótese nula de não associação das variáveis, ou seja, as evidências indicam a independência das variáveis. 


\section{Sentimento / Pensamento}

\begin{tabular}{|c|r|c|c|c|c|c|}
\hline \multirow{2}{*}{} & \multicolumn{3}{|c|}{ Utiliza Cartão de Crédito } & \multicolumn{2}{c|}{} \\
\cline { 2 - 7 } & \multicolumn{2}{|c|}{ Não } & \multicolumn{2}{c|}{ Sim } & \multicolumn{2}{c|}{ Total } \\
\cline { 2 - 7 } & Qtde & $\%$ & Qtde & $\%$ & Qtde & $\%$ \\
\hline Sentimento & 64 & $16,7 \%$ & 320 & $83,3 \%$ & 384 & $100 \%$ \\
Pensamento & 82 & $16,7 \%$ & 410 & $83,3 \%$ & 492 & $100 \%$ \\
Total & 146 & $16,7 \%$ & 730 & $83,3 \%$ & 876 & $100 \%$ \\
\hline
\end{tabular}

Quadro 61 - Tabela Cruzada: Sentimento/Pensamento vs. Cartão de Crédito

Chi-Square Tests

\begin{tabular}{|c|c|c|c|}
\hline & Value & df & $\begin{array}{l}\text { Asymp. Sig. } \\
\text { (2-sided) }\end{array}$ \\
\hline Pearson Chi-Square & ,000 & 1 & 1,000 \\
\hline $\mathrm{N}$ of Valid Cases & 876 & & \\
\hline
\end{tabular}

Quadro 62 - Teste Qui-Quadrado: Sentimento/Pensamento vs. Cartão de Crédito

Teste Qui-Quadrado: Não há evidências que permitam rejeitar a hipótese nula de não associação das variáveis, ou seja, as evidências indicam a independência das variáveis. 
Julgamento / Percepção

\begin{tabular}{|c|r|c|r|c|c|c|}
\hline \multirow{2}{*}{} & \multicolumn{3}{|c|}{ Utiliza Cartão de Crédito } & \multicolumn{2}{|c|}{} \\
\cline { 2 - 7 } & \multicolumn{2}{|c|}{ Não } & \multicolumn{2}{c|}{ Sim } & \multicolumn{2}{c|}{ Total } \\
\cline { 2 - 7 } & Qtde & \multicolumn{1}{|c|}{$\%$} & Qtde & \multicolumn{1}{c|}{$\%$} & Qtde & $\%$ \\
\hline Julgamento & 123 & $16,1 \%$ & 640 & $83,9 \%$ & 763 & $100,0 \%$ \\
Percepção & 23 & $20,4 \%$ & 90 & $79,6 \%$ & 113 & $100,0 \%$ \\
Total & 146 & $16,7 \%$ & 730 & $83,3 \%$ & 876 & $100,0 \%$ \\
\hline
\end{tabular}

Quadro 63 - Tabela Cruzada: Julgamento/Percepção vs. Cartão de Crédito

Chi-Square Tests

\begin{tabular}{|c|c|c|c|}
\hline & Value & $\mathrm{df}$ & $\begin{array}{c}\text { Asymp. Sig. } \\
\text { (2-sided) }\end{array}$ \\
\hline Pearson Chi-Square & 1,270 & 1 & ,260 \\
\hline $\mathrm{N}$ of Valid Cases & 876 & & \\
\hline
\end{tabular}

Quadro 64 - Teste Qui-Quadrado: Julgamento/Percepção vs. Cartão de Crédito

Teste Qui-Quadrado: Não há evidências que permitam rejeitar a hipótese nula de não associação das variáveis, ou seja, as evidências indicam a independência das variáveis. 


\subsubsection{Aplicações em CDB - Certificado de Depósito Bancário}

Os 4 Temperamentos vs. Aplicações em CDB:

\begin{tabular}{|c|r|c|r|c|r|r|}
\hline \multirow{2}{*}{} & \multicolumn{3}{|c|}{ Possui Aplicação em CDB } & \multicolumn{2}{|c|}{} \\
\cline { 2 - 6 } & \multicolumn{2}{|c|}{ Não } & \multicolumn{2}{|c|}{ Sim } & \multicolumn{2}{c|}{ Total } \\
\cline { 2 - 7 } & Qtde & \multicolumn{1}{|c|}{$\%$} & Qtde & $\%$ & Qtde & $\%$ \\
\hline Rational & 142 & $85,5 \%$ & 24 & $14,5 \%$ & 166 & $100 \%$ \\
Idealist & 189 & $88,7 \%$ & 24 & $11,3 \%$ & 213 & $100 \%$ \\
Artisan & 26 & $81,3 \%$ & 6 & $18,8 \%$ & 32 & $100 \%$ \\
Guardian & 411 & $88,4 \%$ & 54 & $11,6 \%$ & 465 & $100 \%$ \\
Total & 768 & $87,7 \%$ & 108 & $12,3 \%$ & 876 & $100 \%$ \\
\hline
\end{tabular}

Quadro 65 - Tabela Cruzada: Os 4 Temperamentos vs. CDB

Chi-Square Tests

\begin{tabular}{|c|c|c|c|}
\hline & Value & df & $\begin{array}{l}\text { Asymp. Sig. } \\
\text { (2-sided) }\end{array}$ \\
\hline Pearson Chi-Square & 2,359 & 3 &, 501 \\
\hline $\mathrm{N}$ of Valid Cases & 876 & & \\
\hline
\end{tabular}

Quadro 66 - Teste Qui-Quadrado: Os 4 Temperamentos vs. CDB

Teste Qui-Quadrado: Não há evidências que permitam rejeitar a hipótese nula de não associação das variáveis, ou seja, as evidências indicam a independência das variáveis. 
Os 16 tipos vs. Aplicações em CDB:

\section{Crosstab}

\begin{tabular}{|c|r|r|r|r|r|r|}
\hline \multirow{2}{*}{} & \multicolumn{3}{|c|}{ Possui Aplicação em CDB } & \multicolumn{2}{c|}{} \\
\cline { 2 - 5 } & \multicolumn{2}{|c|}{ Não } & \multicolumn{2}{|c|}{ Sim } & \multicolumn{2}{c|}{ Total } \\
\cline { 2 - 5 } & Qtde & \multicolumn{1}{|c|}{$\%$} & Qtde & \multicolumn{1}{c|}{$\%$} & Qtde & \multicolumn{1}{c|}{$\%$} \\
\hline ENFJ & 116 & $89,2 \%$ & 14 & $10,8 \%$ & 130 & $100,0 \%$ \\
ENFP & 52 & $86,7 \%$ & 8 & $13,3 \%$ & 60 & $100,0 \%$ \\
ENTJ & 112 & $83,6 \%$ & 22 & $16,4 \%$ & 134 & $100,0 \%$ \\
ENTP & 16 & $100,0 \%$ & 0 &, $0 \%$ & 16 & $100,0 \%$ \\
ESFJ & 110 & $85,3 \%$ & 19 & $14,7 \%$ & 129 & $100,0 \%$ \\
ESFP & 12 & $75,0 \%$ & 4 & $25,0 \%$ & 16 & $100,0 \%$ \\
ESTJ & 240 & $90,6 \%$ & 25 & $9,4 \%$ & 265 & $100,0 \%$ \\
ESTP & 10 & $83,3 \%$ & 2 & $16,7 \%$ & 12 & $100,0 \%$ \\
INFJ & 18 & $90,0 \%$ & 2 & $10,0 \%$ & 20 & $100,0 \%$ \\
INFP & 3 & $100,0 \%$ & 0 &, $0 \%$ & 3 & $100,0 \%$ \\
INTJ & 12 & $85,7 \%$ & 2 & $14,3 \%$ & 14 & $100,0 \%$ \\
INTP & 2 & $100,0 \%$ & 0 &, $0 \%$ & 2 & $100,0 \%$ \\
ISFJ & 19 & $82,6 \%$ & 4 & $17,4 \%$ & 23 & $100,0 \%$ \\
ISFP & 3 & $100,0 \%$ & 0 &, $0 \%$ & 3 & $100,0 \%$ \\
ISTJ & 42 & $87,5 \%$ & 6 & $12,5 \%$ & 48 & $100,0 \%$ \\
ISTP & 1 & $100,0 \%$ & 0 &, $0 \%$ & 1 & $100,0 \%$ \\
Total & 768 & $87,7 \%$ & 108 & $12,3 \%$ & 876 & $100,0 \%$ \\
\hline
\end{tabular}

Quadro 67 - Tabela Cruzada: 16 tipos vs. CDB

Chi-Square Tests

\begin{tabular}{|l|c|r|c|}
\hline & Value & df & \multicolumn{1}{|c|}{$\begin{array}{c}\text { Asymp. Sig. } \\
\text { (2-sided) }\end{array}$} \\
\hline Pearson Chi-Square & 11,961 & 15 &, 682 \\
N of Valid Cases & 876 & & \\
\hline
\end{tabular}

Quadro 68 - Teste Qui-Quadrado: 16 tipos vs. CDB

Teste Qui-Quadrado: Não há evidências que permitam rejeitar a hipótese nula de não associação das variáveis, ou seja, as evidências indicam a independência das variáveis. 
As Dimensões de Temperamentos vs. Aplicação em CDB:

\section{Extroversão / Introversão}

\begin{tabular}{|c|r|r|r|r|r|r|}
\hline \multirow{2}{*}{} & \multicolumn{3}{|c|}{ Possui Aplicação em CDB } & \multirow{2}{*}{} \\
\cline { 2 - 6 } & \multicolumn{2}{|c|}{ Não } & \multicolumn{2}{c|}{ Sim } & \multicolumn{2}{c|}{ Total } \\
\cline { 2 - 7 } & Qtde & \multicolumn{1}{c|}{$\%$} & Qtde & $\%$ & Qtde & $\%$ \\
\hline Extroversão & 668 & $87,7 \%$ & 94 & $12,3 \%$ & 762 & $100,0 \%$ \\
Introversão & 100 & $87,7 \%$ & 14 & $12,3 \%$ & 114 & $100,0 \%$ \\
Total & 768 & $87,7 \%$ & 108 & $12,3 \%$ & 876 & $100,0 \%$ \\
\hline
\end{tabular}

Quadro 69 - Tabela Cruzada: Extroversão/Introversão vs. CDB

Chi-Square Tests

\begin{tabular}{|l|r|r|r|}
\hline & Value & df & $\begin{array}{c}\text { Asymp. Sig. } \\
\text { (2-sided) }\end{array}$ \\
\hline Pearson Chi-Square &, 000 & 1 &, 987 \\
N of Valid Cases & 876 & & \\
\hline
\end{tabular}

Quadro 70 - Teste Qui-Quadrado: Extroversão/Introversão vs. CDB

Teste Qui-Quadrado: Não há evidências que permitam rejeitar a hipótese nula de não associação das variáveis, ou seja, as evidências indicam a independência das variáveis. 
Intuição / Sensação

\begin{tabular}{|c|c|c|r|r|r|r|}
\hline \multirow{2}{*}{} & \multicolumn{3}{|c|}{ Possui Aplicação em CDB } & \multirow{2}{*}{} \\
\cline { 2 - 5 } & \multicolumn{2}{|c|}{ Não } & \multicolumn{2}{c|}{ Sim } & \multicolumn{2}{c|}{ Total } \\
\cline { 2 - 5 } & Qtde & \multicolumn{1}{|c}{$\%$} & \multicolumn{1}{c|}{ Qtde } & \multicolumn{1}{c|}{$\%$} & Qtde & $\%$ \\
\hline Intuição & 331 & $87,3 \%$ & 48 & $12,7 \%$ & 379 & $100,0 \%$ \\
Sensação & 437 & $87,9 \%$ & 60 & $12,1 \%$ & 497 & $100,0 \%$ \\
Total & 768 & $87,7 \%$ & 108 & $12,3 \%$ & 876 & $100,0 \%$ \\
\hline
\end{tabular}

Quadro 71 - Tabela Cruzada: Sensação/Intuição vs. CDB

Chi-Square Tests

\begin{tabular}{|c|c|c|c|}
\hline & Value & $d f$ & $\begin{array}{l}\text { Asymp. Sig. } \\
\text { (2-sided) }\end{array}$ \\
\hline Pearson Chi-Square & ,070 & 1 & ,792 \\
\hline $\mathrm{N}$ of Valid Cases & 876 & & \\
\hline
\end{tabular}

Quadro 72 - Teste Qui-Quadrado: Sensação/Intuição vs. CDB

Teste Qui-Quadrado: Não há evidências que permitam rejeitar a hipótese nula de não associação das variáveis, ou seja, as evidências indicam a independência das variáveis. 
Sentimento / Pensamento

\begin{tabular}{|c|c|c|r|c|c|c|}
\hline \multirow{2}{*}{} & \multicolumn{3}{|c|}{ Possui Aplicação em CDB } & \multicolumn{2}{c|}{} \\
\cline { 2 - 7 } & \multicolumn{2}{|c|}{ Não } & \multicolumn{2}{c|}{ Sim } & \multicolumn{2}{c|}{ Total } \\
\cline { 2 - 7 } & Qtde & \multicolumn{1}{c|}{$\%$} & Qtde & $\%$ & Qtde & $\%$ \\
\hline Sentimento & 333 & $86,7 \%$ & 51 & $13,3 \%$ & 384 & $100,0 \%$ \\
Pensamento & 435 & $88,4 \%$ & 57 & $11,6 \%$ & 492 & $100,0 \%$ \\
Total & 768 & $87,7 \%$ & 108 & $12,3 \%$ & 876 & $100,0 \%$ \\
\hline
\end{tabular}

Quadro 73 - Tabela Cruzada: Sentimento/Pensamento vs. CDB

Chi-Square Tests

\begin{tabular}{|l|r|rr|c|}
\hline & Value & df & $\begin{array}{c}\text { Asymp. Sig. } \\
(2 \text {-sided })\end{array}$ \\
\hline Pearson Chi-Square &, 574 & & 1 &, 449 \\
$N$ of Valid Cases & 876 & & & \\
\hline
\end{tabular}

Quadro 74 - Teste Qui-Quadrado: Sentimento/Pensamento vs. CDB

Teste Qui-Quadrado: Não há evidências que permitam rejeitar a hipótese nula de não associação das variáveis, ou seja, as evidências indicam a independência das variáveis. 
Julgamento / Percepção

\begin{tabular}{|c|r|c|r|r|r|r|}
\hline \multirow{2}{*}{} & \multicolumn{3}{|c|}{ Possui Aplicação em CDB } & \multirow{2}{*}{} \\
\cline { 2 - 5 } & \multicolumn{2}{|c|}{ Não } & \multicolumn{2}{c|}{ Sim } & \multicolumn{2}{c|}{ Total } \\
\cline { 2 - 6 } & Qtde & \multicolumn{1}{|c}{$\%$} & \multicolumn{1}{c|}{ Qtde } & \multicolumn{1}{c|}{$\%$} & Qtde & $\%$ \\
\hline Julgamento & 669 & $87,7 \%$ & 94 & $12,3 \%$ & 763 & $100,0 \%$ \\
Percepção & 99 & $87,6 \%$ & 14 & $12,4 \%$ & 113 & $100,0 \%$ \\
Total & 768 & $87,7 \%$ & 108 & $12,3 \%$ & 876 & $100,0 \%$ \\
\hline
\end{tabular}

Quadro 75 - Tabela Cruzada: Julgamento/Percepção vs. CDB

Chi-Square Tests

\begin{tabular}{|c|c|c|c|}
\hline & Value & df & $\begin{array}{l}\text { Asymp. Sig. } \\
\text { (2-sided) }\end{array}$ \\
\hline $\begin{array}{l}\text { Pearson Chi-Square } \\
\mathrm{N} \text { of Valid Cases }\end{array}$ & $\begin{array}{l}, 000 \\
876\end{array}$ & 1 & ,983 \\
\hline
\end{tabular}

Quadro 76 - Teste Qui-Quadrado: Julgamento/Percepção vs. CDB

Teste Qui-Quadrado: Não há evidências que permitam rejeitar a hipótese nula de não associação das variáveis, ou seja, as evidências indicam a independência das variáveis. 


\subsubsection{Cheque Especial}

Os 4 Temperamentos vs. Utilização de Cheque Especial:

\begin{tabular}{|c|r|r|r|r|r|r|}
\hline \multirow{2}{*}{} & \multicolumn{3}{|c|}{ Utiliza Ch Especial } & \multicolumn{2}{c|}{} \\
\cline { 2 - 6 } & \multicolumn{2}{|c|}{ Não } & \multicolumn{2}{c|}{ Sim } & \multicolumn{2}{c|}{ Total } \\
\cline { 2 - 7 } & Qtde & $\%$ & Qtde & $\%$ & Qtde & $\%$ \\
\hline Rational & 74 & $44,6 \%$ & 92 & $55,4 \%$ & 166 & $100,0 \%$ \\
Idealist & 88 & $41,3 \%$ & 125 & $58,7 \%$ & 213 & $100,0 \%$ \\
Artisan & 10 & $31,3 \%$ & 22 & $68,8 \%$ & 32 & $100,0 \%$ \\
Guardian & 204 & $43,9 \%$ & 261 & $56,1 \%$ & 465 & $100,0 \%$ \\
Total & 376 & $42,9 \%$ & 500 & $57,1 \%$ & 876 & $100,0 \%$ \\
\hline
\end{tabular}

Quadro 77 - Tabela Cruzada: Os 4 Temperamentos vs Cheque Especial

Chi-Square Tests

\begin{tabular}{|c|c|c|c|}
\hline & Value & $\mathrm{df}$ & $\begin{array}{l}\text { Asymp. Sig. } \\
\text { (2-sided) }\end{array}$ \\
\hline Pearson Chi-Square & 2,361 & 3 &, 501 \\
\hline $\mathrm{N}$ of Valid Cases & 876 & & \\
\hline
\end{tabular}

Quadro 78 - Teste Qui-Quadrado: : Os 4 Temperamentos vs Cheque Especial

Teste Qui-Quadrado: Não há evidências que permitam rejeitar a hipótese nula de não associação das variáveis, ou seja, as evidências indicam a independência das variáveis. 
Os 16 tipos vs. Utilização de Cheque Especial:

\begin{tabular}{|c|r|r|r|r|r|r|}
\hline \multirow{2}{*}{} & \multicolumn{3}{|c|}{ Utiliza Ch Especial } & \multicolumn{2}{|c|}{} \\
\cline { 2 - 5 } & \multicolumn{2}{|c|}{ Não } & \multicolumn{2}{|c|}{ Sim } & \multicolumn{2}{c|}{ Total } \\
\cline { 2 - 5 } & Qtde & \multicolumn{1}{c|}{$\%$} & Qtde & \multicolumn{1}{c|}{$\%$} & Qtde & \multicolumn{1}{c|}{$\%$} \\
\hline ENFJ & 51 & $39,2 \%$ & 79 & $60,8 \%$ & 130 & $100,0 \%$ \\
ENFP & 22 & $36,7 \%$ & 38 & $63,3 \%$ & 60 & $100,0 \%$ \\
ENTJ & 60 & $44,8 \%$ & 74 & $55,2 \%$ & 134 & $100,0 \%$ \\
ENTP & 7 & $43,8 \%$ & 9 & $56,3 \%$ & 16 & $100,0 \%$ \\
ESFJ & 55 & $42,6 \%$ & 74 & $57,4 \%$ & 129 & $100,0 \%$ \\
ESFP & 4 & $25,0 \%$ & 12 & $75,0 \%$ & 16 & $100,0 \%$ \\
ESTJ & 112 & $42,3 \%$ & 153 & $57,7 \%$ & 265 & $100,0 \%$ \\
ESTP & 5 & $41,7 \%$ & 7 & $58,3 \%$ & 12 & $100,0 \%$ \\
INFJ & 14 & $70,0 \%$ & 6 & $30,0 \%$ & 20 & $100,0 \%$ \\
INFP & 1 & $33,3 \%$ & 2 & $66,7 \%$ & 3 & $100,0 \%$ \\
INTJ & 7 & $50,0 \%$ & 7 & $50,0 \%$ & 14 & $100,0 \%$ \\
INTP & 0 &, $0 \%$ & 2 & $100,0 \%$ & 2 & $100,0 \%$ \\
ISFJ & 14 & $60,9 \%$ & 9 & $39,1 \%$ & 23 & $100,0 \%$ \\
ISFP & 1 & $33,3 \%$ & 2 & $66,7 \%$ & 3 & $100,0 \%$ \\
ISTJ & 23 & $47,9 \%$ & 25 & $52,1 \%$ & 48 & $100,0 \%$ \\
ISTP & 0 &, $0 \%$ & 1 & $100,0 \%$ & 1 & $100,0 \%$ \\
Total & 376 & $42,9 \%$ & 500 & $57,1 \%$ & 876 & $100,0 \%$ \\
\hline
\end{tabular}

Quadro 79 - Tabela Cruzada: 16 tipos vs. Cheque Especial

Chi-Square Tests

\begin{tabular}{|l|r|r|r|}
\hline & Value & df & \multicolumn{1}{|c|}{$\begin{array}{c}\text { Asymp. Sig. } \\
(2 \text {-sided })\end{array}$} \\
\hline Pearson Chi-Square & 16,296 & 15 &, 363 \\
N of Valid Cases & 876 & & \\
\hline
\end{tabular}

Quadro 80 - Teste Quadrado: 16 tipos vs. Cheque Especial

Teste Qui-Quadrado: Não há evidências que permitam rejeitar a hipótese nula de não associação das variáveis, ou seja, as evidências indicam a independência das variáveis. 
As Dimensões de Temperamentos vs. Utilização de Cheque Especial:

\section{Extroversão / Introversão}

\begin{tabular}{|c|r|c|r|c|c|c|}
\hline \multirow{2}{*}{} & \multicolumn{3}{|c|}{ Utiliza Ch Especial } & \multirow{2}{*}{} \\
\cline { 2 - 7 } & \multicolumn{2}{|c|}{ Não } & \multicolumn{2}{c|}{ Sim } & \multicolumn{2}{c|}{ Total } \\
\cline { 2 - 7 } & Qtde & \multicolumn{1}{|c}{$\%$} & Qtde & \multicolumn{1}{c|}{$\%$} & Qtde & $\%$ \\
\hline Extroversão & 316 & $41,5 \%$ & 446 & $58,5 \%$ & 762 & $100 \%$ \\
Introversão & 60 & $52,6 \%$ & 54 & $47,4 \%$ & 114 & $100 \%$ \\
Total & 376 & $42,9 \%$ & 500 & $57,1 \%$ & 876 & $100 \%$ \\
\hline
\end{tabular}

Quadro 81 - Tabela Cruzada: Extroversão/Introversão vs. Cheque Especial

Chi-Square Tests

\begin{tabular}{|c|c|c|c|}
\hline & Value & $\mathrm{df}$ & $\begin{array}{l}\text { Asymp. Sig. } \\
\text { (2-sided) }\end{array}$ \\
\hline $\begin{array}{l}\text { Pearson Chi-Square } \\
\mathrm{N} \text { of Valid Cases }\end{array}$ & $\begin{array}{r}5,043 \\
876\end{array}$ & 1 & ,025 \\
\hline
\end{tabular}

Quadro 82 - Teste Qui-Quadrado: Extroversão/Introversão vs. Cheque Especial

Teste Qui-Quadrado: Há evidências que permitem rejeitar a hipótese nula de não associação das variáveis, ou seja, as evidências indicam a associação das variáveis. À medida que o perfil se altera de introvertido para extrovertido, altera-se também o percentual de uso do cheque especial. O percentual de usuários que utilizam o limite do cheque especial apresenta-se maior entre os extrovertidos. 
Sensação / Intuição

\begin{tabular}{|c|c|c|c|c|c|c|}
\hline \multirow{2}{*}{} & \multicolumn{3}{|c|}{ Utiliza Ch Especial } & \multicolumn{2}{c|}{} \\
\cline { 2 - 7 } & \multicolumn{2}{|c|}{ Não } & \multicolumn{2}{c|}{ Sim } & \multicolumn{2}{c|}{ Total } \\
\cline { 2 - 6 } & Qtde & $\%$ & Qtde & $\%$ & Qtde & $\%$ \\
\hline Intuição & 162 & $42,7 \%$ & 217 & $57,3 \%$ & 379 & $100 \%$ \\
Sensação & 214 & $43,1 \%$ & 283 & $56,9 \%$ & 497 & $100 \%$ \\
Total & 376 & $42,9 \%$ & 500 & $57,1 \%$ & 876 & $100 \%$ \\
\hline
\end{tabular}

Quadro 83 - Tabela Cruzada: Sensação/Intuição vs. Cheque Especial

Chi-Square Tests

\begin{tabular}{|c|c|c|c|}
\hline & Value & df & $\begin{array}{l}\text { Asymp. Sig. } \\
\text { (2-sided) }\end{array}$ \\
\hline $\begin{array}{l}\text { Pearson Chi-Square } \\
\mathrm{N} \text { of Valid Cases }\end{array}$ & $\begin{array}{l}, 009 \\
876\end{array}$ & 1 & 926 \\
\hline
\end{tabular}

Quadro 84 - Teste Qui-Quadrado: Sensação/Intuição vs. Cheque Especial

Teste Qui-Quadrado: Não há evidências que permitam rejeitar a hipótese nula de não associação das variáveis, ou seja, as evidências indicam a independência das variáveis. 
Sentimento / Pensamento

\begin{tabular}{|c|c|c|c|c|c|c|}
\hline \multirow{2}{*}{} & \multicolumn{3}{|c|}{ Utiliza Ch Especial } & \multirow{2}{*}{} \\
\cline { 2 - 7 } & \multicolumn{2}{|c|}{ Não } & \multicolumn{2}{c|}{ Sim } & \multicolumn{2}{c|}{ Total } \\
\cline { 2 - 6 } & Qtde & $\%$ & Qtde & $\%$ & Qtde & $\%$ \\
\hline Sentimento & 162 & $42,2 \%$ & 222 & $57,8 \%$ & 384 & $100 \%$ \\
Pensamento & 214 & $43,5 \%$ & 278 & $56,5 \%$ & 492 & $100 \%$ \\
Total & 376 & $42,9 \%$ & 500 & $57,1 \%$ & 876 & $100 \%$ \\
\hline
\end{tabular}

Quadro 85 - Tabela Cruzada: Sentimento/Pensamento vs. Cheque Especial Chi-Square Tests

\begin{tabular}{|c|c|c|c|}
\hline & Value & $\mathrm{df}$ & $\begin{array}{l}\text { Asymp. Sig. } \\
\text { (2-sided) }\end{array}$ \\
\hline $\begin{array}{l}\text { Pearson Chi-Square } \\
\mathrm{N} \text { of Valid Cases }\end{array}$ & $\begin{array}{r}, 151 \\
876\end{array}$ & 1 & ,698 \\
\hline
\end{tabular}

Quadro 86 - Teste Qui-Quadrado: Sentimento/Pensamento vs. Cheque Especial

Teste Qui-Quadrado: Não há evidências que permitam rejeitar a hipótese nula de não associação das variáveis, ou seja, as evidências indicam a independência das variáveis. 


\section{Julgamento / Percepção}

\begin{tabular}{|c|r|c|r|r|c|c|}
\hline \multirow{2}{*}{} & \multicolumn{3}{|c|}{ Utiliza Ch Especial } & \multirow{2}{*}{} \\
\cline { 2 - 6 } & \multicolumn{2}{|c|}{ Não } & \multicolumn{2}{c|}{ Sim } & \multicolumn{2}{c|}{ Total } \\
\cline { 2 - 7 } & \multicolumn{1}{|c|}{ Qtde } & \multicolumn{1}{|c|}{$\%$} & Qtde & $\%$ & Qtde & $\%$ \\
\hline Julgamento & 336 & $44,0 \%$ & 427 & $56,0 \%$ & 763 & $100,0 \%$ \\
Percepção & 40 & $35,4 \%$ & 73 & $64,6 \%$ & 113 & $100,0 \%$ \\
Total & 376 & $42,9 \%$ & 500 & $57,1 \%$ & 876 & $100,0 \%$ \\
\hline
\end{tabular}

Quadro 87 - Tabela Cruzada: Julgamento/Percepção vs. Cheque Especial

Chi-Square Tests

\begin{tabular}{|l|r|rr|c|}
\hline & Value & df & $\begin{array}{c}\text { Asymp. Sig. } \\
(2 \text {-sided })\end{array}$ \\
\hline Pearson Chi-Square & 2,998 & & 1 &, 083 \\
$N$ of Valid Cases & 876 & & & \\
\hline
\end{tabular}

Quadro 88 - Teste Qui-Quadrado: Julgamento/Percepção vs. Cheque Especial

Teste Qui-Quadrado: Não há evidências que permitam rejeitar a hipótese nula de não associação das variáveis, ou seja, as evidências indicam a independência das variáveis. 


\subsubsection{Empréstimos e Financiamentos}

Os 4 Temperamentos vs. Empréstimos e Financiamentos

\begin{tabular}{|c|r|r|r|r|r|r|}
\hline \multirow{2}{*}{} & \multicolumn{2}{|c|}{ Possui Outros Emprést./Financ. } & \multicolumn{2}{c|}{} \\
\cline { 2 - 5 } & \multicolumn{2}{|c|}{ Não } & \multicolumn{2}{c|}{ Sim } & \multicolumn{2}{c|}{ Total } \\
\cline { 2 - 7 } & Qtde & \multicolumn{1}{c|}{$\%$} & \multicolumn{1}{c|}{ Qtde } & $\%$ & Qtde & \multicolumn{1}{c|}{$\%$} \\
\hline Rational & 104 & $62,7 \%$ & 62 & $37,3 \%$ & 166 & $100 \%$ \\
Idealist & 147 & $69,0 \%$ & 66 & $31,0 \%$ & 213 & $100 \%$ \\
Artisan & 20 & $62,5 \%$ & 12 & $37,5 \%$ & 32 & $100 \%$ \\
Guardian & 288 & $61,9 \%$ & 177 & $38,1 \%$ & 465 & $100 \%$ \\
Total & 559 & $63,8 \%$ & 317 & $36,2 \%$ & 876 & $100 \%$ \\
\hline
\end{tabular}

Quadro 89 - Tabela Cruzada: Os 4 Temperamentos vs. Empréstimos

Chi-Square Tests

\begin{tabular}{|c|c|c|c|}
\hline & Value & $\mathrm{df}$ & $\begin{array}{l}\text { Asymp. Sig. } \\
\text { (2-sided) }\end{array}$ \\
\hline Pearson Chi-Square & 3,326 & 3 & ,344 \\
\hline $\mathrm{N}$ of Valid Cases & 876 & & \\
\hline
\end{tabular}

Quadro 90 - Teste Qui-Quadrado: Os 4 Temperamentos vs. Empréstimos

Teste qui-quadrado: Não há evidências que permitam rejeitar a hipótese nula de não associação das variáveis, ou seja, as evidências indicam a independência das variáveis. 
Os 16 tipos vs. Empréstimos e Financiamentos

\begin{tabular}{|c|c|c|c|c|c|c|}
\hline & \multicolumn{4}{|c|}{ Possui Outros Emprést./Financ. } & & \\
\hline & \multicolumn{2}{|c|}{ Não } & \multicolumn{2}{|c|}{ Sim } & \multicolumn{2}{|c|}{ Total } \\
\hline & Qtde & $\%$ & Qtde & $\%$ & Qtde & $\%$ \\
\hline ENFJ & 89 & $68,5 \%$ & 41 & $31,5 \%$ & 130 & $100,0 \%$ \\
\hline ENFP & 38 & $63,3 \%$ & 22 & $36,7 \%$ & 60 & $100,0 \%$ \\
\hline ENTJ & 82 & $61,2 \%$ & 52 & $38,8 \%$ & 134 & $100,0 \%$ \\
\hline ENTP & 10 & $62,5 \%$ & 6 & $37,5 \%$ & 16 & $100,0 \%$ \\
\hline ESFJ & 84 & $65,1 \%$ & 45 & $34,9 \%$ & 129 & $100,0 \%$ \\
\hline ESFP & 8 & $50,0 \%$ & 8 & $50,0 \%$ & 16 & $100,0 \%$ \\
\hline ESTJ & 154 & $58,1 \%$ & 111 & $41,9 \%$ & 265 & $100,0 \%$ \\
\hline ESTP & 9 & $75,0 \%$ & 3 & $25,0 \%$ & 12 & $100,0 \%$ \\
\hline INFJ & 19 & $95,0 \%$ & 1 & $5,0 \%$ & 20 & $100,0 \%$ \\
\hline INFP & 1 & $33,3 \%$ & 2 & $66,7 \%$ & 3 & $100,0 \%$ \\
\hline INTJ & 10 & $71,4 \%$ & 4 & $28,6 \%$ & 14 & $100,0 \%$ \\
\hline INTP & 2 & $100,0 \%$ & 0 &, $0 \%$ & 2 & $100,0 \%$ \\
\hline ISFJ & 16 & $69,6 \%$ & 7 & $30,4 \%$ & 23 & $100,0 \%$ \\
\hline ISFP & 2 & $66,7 \%$ & 1 & $33,3 \%$ & 3 & $100,0 \%$ \\
\hline ISTJ & 34 & $70,8 \%$ & 14 & $29,2 \%$ & 48 & $100,0 \%$ \\
\hline ISTP & 1 & $100,0 \%$ & 0 &, $0 \%$ & 1 & $100,0 \%$ \\
\hline Total & 559 & $63,8 \%$ & 317 & $36,2 \%$ & 876 & $100,0 \%$ \\
\hline
\end{tabular}

Quadro 91 - Tabela Cruzada: 16 tipos vs. Empréstimos

Chi-Square Tests

\begin{tabular}{|l|r|r|r|}
\hline & \multicolumn{1}{|c|}{ Value } & \multicolumn{1}{c|}{ df } & \multicolumn{1}{c|}{$\begin{array}{c}\text { Asymp. Sig. } \\
\text { (2-sided) }\end{array}$} \\
\hline Pearson Chi-Square & 20,476 & 15 &, 154 \\
N of Valid Cases & 876 & & \\
\hline
\end{tabular}

Quadro 92 - Teste Qui-Quadrado: 16 tipos vs. Empréstimos

Teste do Qui-Quadrado: Não há evidências que permitam rejeitar a hipótese nula de não associação das variáveis, ou seja, as evidências indicam a independência das variáveis. 
As Dimensões do Temperamento vs. Empréstimos e Financiamentos:

\section{Extroversão / Introversão}

\begin{tabular}{|c|r|c|r|r|r|c|}
\hline \multirow{2}{*}{} & \multicolumn{2}{|c|}{ Possui Outros Emprést./Financ. } & \multicolumn{2}{c|}{} \\
\cline { 2 - 7 } & \multicolumn{2}{|c|}{ Não } & \multicolumn{2}{c|}{ Sim } & \multicolumn{2}{c|}{ Total } \\
\cline { 2 - 7 } & Qtde & \multicolumn{1}{c|}{$\%$} & Qtde & $\%$ & Qtde & $\%$ \\
\hline Extroversão & 474 & $62,2 \%$ & 288 & $37,8 \%$ & 762 & $100 \%$ \\
Introversão & 85 & $74,6 \%$ & 29 & $25,4 \%$ & 114 & $100 \%$ \\
Total & 559 & $63,8 \%$ & 317 & $36,2 \%$ & 876 & $100 \%$ \\
\hline
\end{tabular}

Quadro 93 - Tabela Cruzada: Extroversão/Introversão vs. Empréstimos

Chi-Square Tests

\begin{tabular}{|c|c|c|c|}
\hline & Value & df & $\begin{array}{l}\text { Asymp. Sig. } \\
\text { (2-sided) }\end{array}$ \\
\hline $\begin{array}{l}\text { Pearson Chi-Square } \\
\mathrm{N} \text { of Valid Cases }\end{array}$ & $\begin{array}{r}6,557 \\
876\end{array}$ & $\overline{1}$ & 010, \\
\hline
\end{tabular}

Quadro 94 - Teste Qui-Quadrado: Extroversão/Introversão vs. Empréstimos

Teste qui-quadrado: Há evidências que permitem rejeitar a hipótese nula de não associação das variáveis, ou seja, as evidências indicam a associação das variáveis.

Os indivíduos extrovertidos possuem mais empréstimos e financiamentos do que os introvertidos e essa diferença é estatisticamente significante. 
Sensação / Intuição

\begin{tabular}{|c|c|c|c|c|c|c|}
\hline \multirow{2}{*}{} & \multicolumn{2}{|c|}{ Possui Outros Emprést./Financ. } & \multicolumn{2}{c|}{} \\
\cline { 2 - 7 } & \multicolumn{2}{|c|}{ Não } & \multicolumn{2}{c|}{ Sim } & \multicolumn{2}{c|}{ Total } \\
\cline { 2 - 7 } & Qtde & $\%$ & Qtde & $\%$ & Qtde & $\%$ \\
\hline Intuição & 251 & $66,2 \%$ & 128 & $33,8 \%$ & 379 & $100 \%$ \\
Sensação & 308 & $62,0 \%$ & 189 & $38,0 \%$ & 497 & $100 \%$ \\
Total & 559 & $63,8 \%$ & 317 & $36,2 \%$ & 876 & $100 \%$ \\
\hline
\end{tabular}

Quadro 95 - Tabela Cruzada: Sensação/Intuição vs. Empréstimos

Chi-Square Tests

\begin{tabular}{|l|r|rr|c|}
\hline & Value & df & $\begin{array}{c}\text { Asymp. Sig. } \\
\text { (2-sided) }\end{array}$ \\
\hline Pearson Chi-Square & 1,686 & & 1 &, 194 \\
$N$ of Valid Cases & 876 & & & \\
\hline
\end{tabular}

Quadro 96 - Teste Qui-Quadrado: Sensação/Intuição vs. Empréstimos

Teste Qui-Quadrado: Não há evidências que permitam rejeitar a hipótese nula de não associação das variáveis, ou seja, as evidências indicam a independência das variáveis. 


\section{Sentimento / Pensamento}

\begin{tabular}{|c|c|c|c|c|c|c|}
\hline \multirow{2}{*}{} & \multicolumn{3}{|c|}{ Possui Outros Emprést./Financ. } & \multicolumn{2}{c|}{} \\
\cline { 2 - 5 } & \multicolumn{2}{|c|}{ Não } & \multicolumn{2}{c|}{ Sim } & \multicolumn{2}{c|}{ Total } \\
\cline { 2 - 5 } & Qtde & $\%$ & Qtde & $\%$ & Qtde & $\%$ \\
\hline Sentimento & 257 & $66,9 \%$ & 127 & $33,1 \%$ & 384 & $100 \%$ \\
Pensamento & 302 & $61,4 \%$ & 190 & $38,6 \%$ & 492 & $100 \%$ \\
Total & 559 & $63,8 \%$ & 317 & $36,2 \%$ & 876 & $100 \%$ \\
\hline
\end{tabular}

Quadro 97 - Tabela Cruzada: Sensação/Intuição vs. Empréstimos

Chi-Square Tests

\begin{tabular}{|c|c|c|c|}
\hline & Value & $\mathrm{df}$ & $\begin{array}{l}\text { Asymp. Sig. } \\
\text { (2-sided) }\end{array}$ \\
\hline $\begin{array}{l}\text { Pearson Chi-Square } \\
\mathrm{N} \text { of Valid Cases }\end{array}$ & $\begin{array}{r}2,872 \\
876\end{array}$ & 1 & ,090 \\
\hline
\end{tabular}

Quadro 98 - Teste Qui-Quadrado: Sensação/Intuição vs. Empréstimos

Teste Qui-Quadrado: Não há evidências que permitam rejeitar a hipótese nula de não associação das variáveis, ou seja, as evidências indicam a independência das variáveis. 
Julgamento / Percepção

\begin{tabular}{|c|r|c|r|c|c|c|}
\hline \multirow{2}{*}{} & \multicolumn{2}{|c|}{ Possui Outros Emprést./Financ. } & \multicolumn{2}{|c|}{} \\
\cline { 2 - 6 } & \multicolumn{2}{|c|}{ Não } & \multicolumn{2}{c|}{ Sim } & \multicolumn{2}{c|}{ Total } \\
\cline { 2 - 7 } & Qtde & $\%$ & \multicolumn{1}{c|}{ Qtde } & $\%$ & Qtde & $\%$ \\
\hline Julgamento & 488 & $64,0 \%$ & 275 & $36,0 \%$ & 763 & $100 \%$ \\
Percepção & 71 & $62,8 \%$ & 42 & $37,2 \%$ & 113 & $100 \%$ \\
Total & 559 & $63,8 \%$ & 317 & $36,2 \%$ & 876 & $100 \%$ \\
\hline
\end{tabular}

Quadro 99 - Tabela Cruzada: Julgamento/Percepção vs. Empréstimos

Chi-Square Tests

\begin{tabular}{|c|c|c|c|}
\hline & Value & df & $\begin{array}{l}\text { Asymp. Sig. } \\
\text { (2-sided) }\end{array}$ \\
\hline $\begin{array}{l}\text { Pearson Chi-Square } \\
\mathrm{N} \text { of Valid Cases }\end{array}$ & $\begin{array}{r}, 054 \\
876\end{array}$ & 1 & ,816 \\
\hline
\end{tabular}

Quadro 100 - Teste Qui-Quadrado: Julgamento/Percepção vs. Empréstimos

Teste Qui-Quadrado: Não há evidências que permitam rejeitar a hipótese nula de não associação das variáveis, ou seja, as evidências indicam a independência das variáveis. 


\subsubsection{Aplicação em Fundos de Investimentos}

Os 4 Temperamentos vs. Aplicação em Fundos de Investimentos

\begin{tabular}{|c|r|r|r|r|r|r|}
\hline \multirow{2}{*}{} & \multicolumn{3}{|c|}{$\begin{array}{c}\text { Possui Aplicação em Fundos de } \\
\text { Investimentos }\end{array}$} & \multicolumn{2}{|c|}{} \\
\cline { 2 - 5 } & \multicolumn{2}{|c|}{ Não } & \multicolumn{2}{|c|}{ Sim } & \multicolumn{2}{c|}{ Total } \\
\cline { 2 - 7 } & Qtde & \multicolumn{1}{|c|}{$\%$} & Qtde & \multicolumn{1}{c|}{$\%$} & Qtde & \multicolumn{1}{c|}{$\%$} \\
\hline Rational & 141 & $84,9 \%$ & 25 & $15,1 \%$ & 166 & $100,0 \%$ \\
Idealist & 177 & $83,1 \%$ & 36 & $16,9 \%$ & 213 & $100,0 \%$ \\
Artisan & 29 & $90,6 \%$ & 3 & $9,4 \%$ & 32 & $100,0 \%$ \\
Guardian & 407 & $87,5 \%$ & 58 & $12,5 \%$ & 465 & $100,0 \%$ \\
Total & 754 & $86,1 \%$ & 122 & $13,9 \%$ & 876 & $100,0 \%$ \\
\hline
\end{tabular}

Quadro 101 - Tabela Cruzada: Os 4 Temperamentos vs. Fundos de Investimentos

Chi-Square Tests

\begin{tabular}{|c|c|c|c|}
\hline & Value & $\mathrm{df}$ & $\begin{array}{c}\text { Asymp. Sig. } \\
\text { (2-sided) }\end{array}$ \\
\hline Pearson Chi-Square & 3,123 & 3 & ,373 \\
\hline $\mathrm{N}$ of Valid Cases & 876 & & \\
\hline
\end{tabular}

Quadro 102 - Teste Qui-Quadrado: Os 4 Temperamentos vs. Fundos de Investimentos

Teste qui-quadrado: Não há evidências que permitam rejeitar a hipótese nula de não associação das variáveis, ou seja, as evidências indicam a independência das variáveis 
Os 16 tipos vs. Aplicação em Fundos de Investimentos

\begin{tabular}{|c|c|c|c|c|c|c|}
\hline & \multicolumn{4}{|c|}{$\begin{array}{l}\text { Possui Aplicação em Fundos de } \\
\text { Investimentos }\end{array}$} & \multirow{2}{*}{\multicolumn{2}{|c|}{ Total }} \\
\hline & \multicolumn{2}{|c|}{ Não } & \multicolumn{2}{|c|}{ Sim } & & \\
\hline & Qtde & $\%$ & Qtde & $\%$ & Qtde & $\%$ \\
\hline ENFJ & 104 & $80,0 \%$ & 26 & $20,0 \%$ & 130 & $100 \%$ \\
\hline ENFP & 52 & $86,7 \%$ & 8 & $13,3 \%$ & 60 & $100 \%$ \\
\hline ENTJ & 112 & $83,6 \%$ & 22 & $16,4 \%$ & 134 & $100 \%$ \\
\hline ENTP & 15 & $93,8 \%$ & 1 & $6,3 \%$ & 16 & $100 \%$ \\
\hline ESFJ & 111 & $86,0 \%$ & 18 & $14,0 \%$ & 129 & $100 \%$ \\
\hline ESFP & 14 & $87,5 \%$ & 2 & $12,5 \%$ & 16 & $100 \%$ \\
\hline ESTJ & 234 & $88,3 \%$ & 31 & $11,7 \%$ & 265 & $100 \%$ \\
\hline ESTP & 11 & $91,7 \%$ & 1 & $8,3 \%$ & 12 & $100 \%$ \\
\hline INFJ & 18 & $90,0 \%$ & 2 & $10,0 \%$ & 20 & $100 \%$ \\
\hline INFP & 3 & $100 \%$ & 0 & ,0\% & 3 & $100 \%$ \\
\hline INTJ & 12 & $85,7 \%$ & 2 & $14,3 \%$ & 14 & $100 \%$ \\
\hline INTP & 2 & $100 \%$ & 0 & ,0\% & 2 & $100 \%$ \\
\hline ISFJ & 20 & $87,0 \%$ & 3 & $13,0 \%$ & 23 & $100 \%$ \\
\hline ISFP & 3 & $100 \%$ & 0 &, $0 \%$ & 3 & $100 \%$ \\
\hline ISTJ & 42 & $87,5 \%$ & 6 & $12,5 \%$ & 48 & $100 \%$ \\
\hline ISTP & 1 & $100 \%$ & 0 & ,0\% & 1 & $100 \%$ \\
\hline Total & 754 & $86,1 \%$ & 122 & $13,9 \%$ & 876 & $100 \%$ \\
\hline
\end{tabular}

Quadro 103 - Tabela Cruzada: 16 tipos vs. Fundos de Investimentos

Chi-Square Tests

\begin{tabular}{|l|r|r|r|}
\hline & Value & df & \multicolumn{1}{|c|}{$\begin{array}{c}\text { Asymp. Sig. } \\
\text { (2-sided) }\end{array}$} \\
\hline Pearson Chi-Square & 8,748 & 15 &, 890 \\
N of Valid Cases & 876 & & \\
\hline
\end{tabular}

Quadro 104 - Teste Qui-Quadrado: 16 tipos vs. Fundos de Investimentos

Teste qui-quadrado: Não há evidências que permitam rejeitar a hipótese nula de não associação das variáveis, ou seja, as evidências indicam a independência das variáveis 
As Dimensões de Temperamentos vs. Aplicações em Fundos de Investimentos.

\section{Extroversão / Introversão}

\begin{tabular}{|c|c|c|r|r|r|r|}
\hline \multirow{2}{*}{} & \multicolumn{3}{|c|}{$\begin{array}{c}\text { Possui Aplicação em Fundos de } \\
\text { Investimentos }\end{array}$} & \multicolumn{2}{c|}{} \\
\cline { 2 - 6 } & \multicolumn{2}{|c|}{ Não } & \multicolumn{2}{c|}{ Sim } & \multicolumn{2}{c|}{ Total } \\
\cline { 2 - 7 } & Qtde & $\%$ & Qtde & $\%$ & Qtde & $\%$ \\
\hline Extroversão & 653 & $85,7 \%$ & 109 & $14,3 \%$ & 762 & $100 \%$ \\
Introversão & 101 & $88,6 \%$ & 13 & $11,4 \%$ & 114 & $100 \%$ \\
Total & 754 & $86,1 \%$ & 122 & $13,9 \%$ & 876 & $100 \%$ \\
\hline
\end{tabular}

Quadro 105 - Tabela Cruzada: Extroversão/Introversão vs. Fundos de Investimentos

\section{Chi-Square Tests}

\begin{tabular}{|c|c|c|c|}
\hline & Value & $\mathrm{df}$ & $\begin{array}{l}\text { Asymp. Sig. } \\
\text { (2-sided) }\end{array}$ \\
\hline $\begin{array}{l}\text { Pearson Chi-Square } \\
\mathrm{N} \text { of Valid Cases }\end{array}$ & $\begin{array}{r}, 696 \\
876\end{array}$ & 1 & ,404 \\
\hline
\end{tabular}

Quadro 106 - Teste Qui-Quadrado: Extroversão/Introversão vs. Fundos de Investimentos

Teste Qui-Quadrado: Não há evidências que permitam rejeitar a hipótese nula de não associação das variáveis, ou seja, as evidências indicam a independência das variáveis. 
Intuição / Sensação:

\begin{tabular}{|c|c|c|r|r|r|r|}
\multicolumn{9}{|c|}{ Crosstab } \\
\hline \multirow{2}{*}{} & \multicolumn{3}{|c|}{$\begin{array}{c}\text { Possui Aplicação em Fundos de } \\
\text { Investimentos }\end{array}$} & \multicolumn{2}{c|}{} \\
\cline { 2 - 6 } & \multicolumn{2}{|c|}{ Não } & \multicolumn{2}{c|}{ Sim } & \multicolumn{2}{c|}{ Total } \\
\cline { 2 - 7 } & Qtde & $\%$ & Qtde & $\%$ & Qtde & $\%$ \\
\hline Intuição & 318 & $83,9 \%$ & 61 & $16,1 \%$ & 379 & $100,0 \%$ \\
Sensação & 436 & $87,7 \%$ & 61 & $12,3 \%$ & 497 & $100,0 \%$ \\
Total & 754 & $86,1 \%$ & 122 & $13,9 \%$ & 876 & $100,0 \%$ \\
\hline
\end{tabular}

Quadro 107 - Tabela Cruzada: Sensação/Intuição vs. Fundos de Investimentos

Chi-Square Tests

\begin{tabular}{|c|c|c|c|}
\hline & Value & df & $\begin{array}{l}\text { Asymp. Sig. } \\
\text { (2-sided) }\end{array}$ \\
\hline $\begin{array}{l}\text { Pearson Chi-Square } \\
\mathrm{N} \text { of Valid Cases }\end{array}$ & $\begin{array}{r}2,619 \\
876\end{array}$ & 1 & 106 \\
\hline
\end{tabular}

Quadro 108 - Teste Qui-Quadrado: : Sensação/Intuição vs. Fundos de Investimentos

Teste Qui-Quadrado: Não há evidências que permitam rejeitar a hipótese nula de não associação das variáveis, ou seja, as evidências indicam a independência das variáveis. 


\section{Pensamento / Sentimento}

\begin{tabular}{|c|c|c|r|r|r|r|}
\hline \multirow{2}{*}{} & \multicolumn{3}{|c|}{$\begin{array}{c}\text { Possui Aplicação em Fundos de } \\
\text { Investimentos }\end{array}$} & \multicolumn{2}{c|}{ Total } \\
\cline { 2 - 7 } & \multicolumn{2}{|c|}{ Não } & \multicolumn{2}{c|}{ Sim } & \multicolumn{2}{c|}{} \\
\cline { 2 - 7 } & Qtde & $\%$ & Qtde & $\%$ & Qtde & $\%$ \\
\hline Sentimento & 325 & $84,6 \%$ & 59 & $15,4 \%$ & 384 & $100,0 \%$ \\
Pensamento & 429 & $87,2 \%$ & 63 & $12,8 \%$ & 492 & $100,0 \%$ \\
Total & 754 & $86,1 \%$ & 122 & $13,9 \%$ & 876 & $100,0 \%$ \\
\hline
\end{tabular}

Quadro 109 - Tabela Cruzada: Sentimento/Pensamento vs. Fundos de Investimentos

Chi-Square Tests

\begin{tabular}{|c|c|c|c|}
\hline & Value & df & $\begin{array}{l}\text { Asymp. Sig. } \\
\text { (2-sided) }\end{array}$ \\
\hline $\begin{array}{l}\text { Pearson Chi-Square } \\
\mathrm{N} \text { of Valid Cases }\end{array}$ & $\begin{array}{r}1,179 \\
876\end{array}$ & 1 & ,278 \\
\hline
\end{tabular}

Quadro 110 - Teste Qui-Quadrado: Sentimento/Pensamento vs. Fundos de Investimentos

Teste Qui-Quadrado: Não há evidências que permitam rejeitar a hipótese nula de não associação das variáveis, ou seja, as evidências indicam a independência das variáveis. 
Julgamento / Percepção:

\begin{tabular}{|c|c|c|r|r|r|r|}
\hline \multirow{2}{*}{} & \multicolumn{3}{|c|}{$\begin{array}{c}\text { Possui Aplicação em Fundos de } \\
\text { Investimentos }\end{array}$} & \multirow{2}{*}{} \\
\cline { 2 - 7 } & \multicolumn{2}{|c|}{ Não } & \multicolumn{2}{c|}{ Sim } & \multicolumn{2}{c|}{ Total } \\
\cline { 2 - 7 } & Qtde & $\%$ & Qtde & \multicolumn{1}{c|}{$\%$} & Qtde & $\%$ \\
\hline Julgamento & 653 & $85,6 \%$ & 110 & $14,4 \%$ & 763 & $100,0 \%$ \\
Percepção & 101 & $89,4 \%$ & 12 & $10,6 \%$ & 113 & $100,0 \%$ \\
Total & 754 & $86,1 \%$ & 122 & $13,9 \%$ & 876 & $100,0 \%$ \\
\hline
\end{tabular}

Quadro 111 - Tabela Cruzada: Julgamento/Percepção vs. Fundos de Investimentos

Chi-Square Tests

\begin{tabular}{|c|c|c|c|}
\hline & Value & df & $\begin{array}{l}\text { Asymp. Sig. } \\
\text { (2-sided) }\end{array}$ \\
\hline $\begin{array}{l}\text { Pearson Chi-Square } \\
\mathrm{N} \text { of Valid Cases }\end{array}$ & 1,184 & 1 & ,277 \\
\hline
\end{tabular}

Quadro 112 - Teste Qui-Quadrado: Julgamento/Percepção vs. Fundos de Investimentos

Teste Qui-Quadrado: Não há evidências que permitam rejeitar a hipótese nula de não associação das variáveis, ou seja, as evidências indicam a independência das variáveis. 


\subsubsection{Crédito Pessoal}

Os 4 Temperamentos vs. Crédito Pessoal

\begin{tabular}{|c|r|c|r|r|r|r|}
\hline \multirow{2}{*}{} & \multicolumn{3}{|c|}{ Utiliza Crédito Pessoal } & \multicolumn{2}{|c|}{} \\
\cline { 2 - 6 } & \multicolumn{2}{|c|}{ Não } & \multicolumn{2}{c|}{ Sim } & \multicolumn{2}{c|}{ Total } \\
\cline { 2 - 6 } & Qtde & \multicolumn{1}{|c}{$\%$} & Qtde & $\%$ & Qtde & \multicolumn{1}{c|}{$\%$} \\
\hline Rational & 142 & $85,5 \%$ & 24 & $14,5 \%$ & 166 & $100 \%$ \\
Idealist & 185 & $86,9 \%$ & 28 & $13,1 \%$ & 213 & $100 \%$ \\
Artisan & 27 & $84,4 \%$ & 5 & $15,6 \%$ & 32 & $100 \%$ \\
Guardian & 401 & $86,2 \%$ & 64 & $13,8 \%$ & 465 & $100 \%$ \\
Total & 755 & $86,2 \%$ & 121 & $13,8 \%$ & 876 & $100 \%$ \\
\hline
\end{tabular}

Quadro 113- Tabela Cruzada: Os 4 Temperamentos vs. Crédito Pessoal

Chi-Square Tests

\begin{tabular}{|l|r|r|c|}
\hline & Value & df & $\begin{array}{c}\text { Asymp. Sig. } \\
\text { (2-sided) }\end{array}$ \\
\hline Pearson Chi-Square &, 227 & & 3 \\
N of Valid Cases & 876 & &, 973 \\
\hline
\end{tabular}

Quadro 114 - Teste Qui-Quadrado: Os 4 Temperamentos vs. Crédito Pessoal

Teste qui-quadrado: Não há evidências que permitam rejeitar a hipótese nula de não associação das variáveis, ou seja, as evidências indicam a independência das variáveis. 
Os 16 tipos vs. Crédito Pessoal:

\begin{tabular}{|c|r|r|r|r|r|r|}
\hline \multirow{2}{*}{} & \multicolumn{3}{|c|}{ Utiliza Crédito Pessoal } & \multicolumn{2}{|c|}{} \\
\cline { 2 - 6 } & \multicolumn{2}{|c|}{ Não } & \multicolumn{2}{c|}{ Sim } & \multicolumn{2}{c|}{ Total } \\
\cline { 2 - 6 } & Qtde & \multicolumn{1}{c|}{$\%$} & Qtde & \multicolumn{1}{c|}{$\%$} & Qtde & \multicolumn{1}{c}{$\%$} \\
\hline ENFJ & 110 & $84,6 \%$ & 20 & $15,4 \%$ & 130 & $100,0 \%$ \\
ENFP & 55 & $91,7 \%$ & 5 & $8,3 \%$ & 60 & $100,0 \%$ \\
ENTJ & 117 & $87,3 \%$ & 17 & $12,7 \%$ & 134 & $100,0 \%$ \\
ENTP & 11 & $68,8 \%$ & 5 & $31,3 \%$ & 16 & $100,0 \%$ \\
ESFJ & 111 & $86,0 \%$ & 18 & $14,0 \%$ & 129 & $100,0 \%$ \\
ESFP & 12 & $75,0 \%$ & 4 & $25,0 \%$ & 16 & $100,0 \%$ \\
ESTJ & 224 & $84,5 \%$ & 41 & $15,5 \%$ & 265 & $100,0 \%$ \\
ESTP & 11 & $91,7 \%$ & 1 & $8,3 \%$ & 12 & $100,0 \%$ \\
INFJ & 17 & $85,0 \%$ & 3 & $15,0 \%$ & 20 & $100,0 \%$ \\
INFP & 3 & $100,0 \%$ & 0 &, $0 \%$ & 3 & $100,0 \%$ \\
INTJ & 13 & $92,9 \%$ & 1 & $7,1 \%$ & 14 & $100,0 \%$ \\
INTP & 1 & $50,0 \%$ & 1 & $50,0 \%$ & 2 & $100,0 \%$ \\
ISFJ & 22 & $95,7 \%$ & 1 & $4,3 \%$ & 23 & $100,0 \%$ \\
ISFP & 3 & $100,0 \%$ & 0 &, $0 \%$ & 3 & $100,0 \%$ \\
ISTJ & 44 & $91,7 \%$ & 4 & $8,3 \%$ & 48 & $100,0 \%$ \\
ISTP & 1 & $100,0 \%$ & 0 &, $0 \%$ & 1 & $100,0 \%$ \\
Total & 755 & $86,2 \%$ & 121 & $13,8 \%$ & 876 & $100,0 \%$ \\
\hline
\end{tabular}

Quadro 115 - Tabela Cruzada: 16 tipos vs. Crédito Pessoal

Chi-Square Tests

\begin{tabular}{|l|r|r|r|}
\hline & Value & df & \multicolumn{1}{|c|}{$\begin{array}{c}\text { Asymp. Sig. } \\
\text { (2-sided) }\end{array}$} \\
\hline Pearson Chi-Square & 15,422 & 15 &, 421 \\
N of Valid Cases & 876 & & \\
\hline
\end{tabular}

Quadro 116 - Teste Qui-Quadrado: 16 tipos vs. Crédito Pessoal

Teste qui-quadrado: Não há evidências que permitam rejeitar a hipótese nula de não associação das variáveis, ou seja, as evidências indicam a independência das variáveis. 
As Dimensões de Temperamentos vs. Crédito Pessoal.

\section{Extroversão / Introversão}

\begin{tabular}{|c|r|r|r|r|r|r|}
\hline \multirow{2}{*}{} & \multicolumn{3}{|c|}{ Utiliza Crédito Pessoal } & \multirow{2}{*}{} \\
\cline { 2 - 6 } & \multicolumn{2}{|c|}{ Não } & \multicolumn{2}{c|}{ Sim } & \multicolumn{2}{c|}{ Total } \\
\cline { 2 - 7 } & Qtde & \multicolumn{1}{|c|}{$\%$} & \multicolumn{1}{c|}{ Qtde } & \multicolumn{1}{c|}{$\%$} & Qtde & \multicolumn{1}{c|}{$\%$} \\
\hline Extroversão & 651 & $85,4 \%$ & 111 & $14,6 \%$ & 762 & $100,0 \%$ \\
Introversão & 104 & $91,2 \%$ & 10 & $8,8 \%$ & 114 & $100,0 \%$ \\
Total & 755 & $86,2 \%$ & 121 & $13,8 \%$ & 876 & $100,0 \%$ \\
\hline
\end{tabular}

Quadro 117 - Tabela Cruzada: Extroversão/Introversão vs. Crédito Pessoal

Chi-Square Tests

\begin{tabular}{|c|c|c|c|}
\hline & Value & $\mathrm{df}$ & $\begin{array}{l}\text { Asymp. Sig. } \\
\text { (2-sided) }\end{array}$ \\
\hline Pearson Chi-Square & 2,797 & $\overline{1}$ & ,094 \\
\hline
\end{tabular}

Quadro 118 - Teste Qui-Quadrado: Extroversão/Introversão vs. Crédito Pessoal

Teste qui-quadrado: Não há evidências que permitam rejeitar a hipótese nula de não associação das variáveis, ou seja, as evidências indicam a independência das variáveis. 
Sensação / Intuição

\begin{tabular}{|c|c|c|r|c|c|c|}
\hline \multirow{2}{*}{} & \multicolumn{3}{|c|}{ Utiliza Crédito Pessoal } & \multicolumn{2}{|c|}{} \\
\cline { 2 - 6 } & \multicolumn{2}{|c|}{ Não } & \multicolumn{2}{c|}{ Sim } & \multicolumn{2}{c|}{ Total } \\
\cline { 2 - 7 } & Qtde & \multicolumn{1}{c|}{$\%$} & Qtde & $\%$ & Qtde & $\%$ \\
\hline Intuição & 327 & $86,3 \%$ & 52 & $13,7 \%$ & 379 & $100 \%$ \\
Sensação & 428 & $86,1 \%$ & 69 & $13,9 \%$ & 497 & $100 \%$ \\
Total & 755 & $86,2 \%$ & 121 & $13,8 \%$ & 876 & $100 \%$ \\
\hline
\end{tabular}

Quadro 119 - Tabela Cruzada: Sensação/Intuição vs. Crédito Pessoal

Chi-Square Tests

\begin{tabular}{|c|c|c|c|}
\hline & Value & $\mathrm{df}$ & $\begin{array}{l}\text { Asymp. Sig. } \\
\text { (2-sided) }\end{array}$ \\
\hline Pearson Chi-Square & 005 & 1 & ,945 \\
\hline
\end{tabular}

Quadro 120 - Teste Qui-Quadrado: Sensação/Intuição vs. Crédito Pessoal

Teste qui-quadrado: Não há evidências que permitam rejeitar a hipótese nula de não associação das variáveis, ou seja, as evidências indicam a independência das variáveis. 
Sentimento / Pensamento

\begin{tabular}{|c|c|c|r|c|c|c|}
\hline \multirow{2}{*}{} & \multicolumn{3}{|c|}{ Utiliza Crédito Pessoal } & \multirow{2}{*}{} \\
\cline { 2 - 7 } & \multicolumn{2}{|c|}{ Não } & \multicolumn{2}{c|}{ Sim } & \multicolumn{2}{c|}{ Total } \\
\cline { 2 - 7 } & Qtde & \multicolumn{1}{c|}{$\%$} & Qtde & \multicolumn{1}{c|}{$\%$} & Qtde & $\%$ \\
\hline Sentimento & 333 & $86,7 \%$ & 51 & $13,3 \%$ & 384 & $100 \%$ \\
Pensamento & 422 & $85,8 \%$ & 70 & $14,2 \%$ & 492 & $100 \%$ \\
Total & 755 & $86,2 \%$ & 121 & $13,8 \%$ & 876 & $100 \%$ \\
\hline
\end{tabular}

Quadro 121 - Tabela Cruzada: Sentimento/Pensamento vs. Crédito Pessoal

Chi-Square Tests

\begin{tabular}{|c|c|c|c|}
\hline & Value & df & $\begin{array}{l}\text { Asymp. Sig. } \\
\text { (2-sided) }\end{array}$ \\
\hline Pearson Chi-Square & ,162 & 1 & ,687 \\
\hline $\mathrm{N}$ of Valid Cases & 876 & & \\
\hline
\end{tabular}

Quadro 122 - Teste Qui-Quadrado: Sentimento/Pensamento vs. Crédito Pessoal

Teste qui-quadrado: Não há evidências que permitam rejeitar a hipótese nula de não associação das variáveis, ou seja, as evidências indicam a independência das variáveis. 
Julgamento / Percepção

\begin{tabular}{|c|r|c|r|r|r|r|}
\hline \multirow{2}{*}{} & \multicolumn{3}{|c|}{ Utiliza Crédito Pessoal } & \multicolumn{2}{c|}{} \\
\cline { 2 - 7 } & \multicolumn{2}{|c|}{ Não } & \multicolumn{2}{c|}{ Sim } & \multicolumn{2}{c|}{ Total } \\
\cline { 2 - 7 } & Qtde & \multicolumn{1}{|c}{$\%$} & \multicolumn{1}{c|}{ Qtde } & \multicolumn{1}{c|}{$\%$} & Qtde & $\%$ \\
\hline Julgamento & 658 & $86,2 \%$ & 105 & $13,8 \%$ & 763 & $100,0 \%$ \\
Percepção & 97 & $85,8 \%$ & 16 & $14,2 \%$ & 113 & $100,0 \%$ \\
Total & 755 & $86,2 \%$ & 121 & $13,8 \%$ & 876 & $100,0 \%$ \\
\hline
\end{tabular}

Quadro 123 - Tabela Cruzada: Julgamento/Percepção vs. Crédito Pessoal

Chi-Square Tests

\begin{tabular}{|l|r|rr|c|}
\hline & Value & df & $\begin{array}{c}\text { Asymp. Sig. } \\
\text { (2-sided) }\end{array}$ \\
\hline Pearson Chi-Square &, 013 & & 1 &, 909 \\
$N$ of Valid Cases & 876 & & & \\
\hline
\end{tabular}

Quadro 124 - Teste Qui-Quadrado: Julgamento/Percepção vs. Crédito Pessoal

Teste Qui-Quadrado: Não há evidências que permitam rejeitar a hipótese nula de não associação das variáveis, ou seja, as evidências indicam a independência das variáveis. 


\subsubsection{Previdência}

Os 4 Temperamentos vs. Previdência

\begin{tabular}{|c|r|c|r|r|r|r|}
\hline \multirow{2}{*}{} & \multicolumn{3}{|c|}{ Possui Previdência } & \multicolumn{2}{c|}{} \\
\cline { 2 - 6 } & \multicolumn{2}{|c|}{ Não } & \multicolumn{2}{|c|}{ Sim } & \multicolumn{2}{c|}{ Total } \\
\cline { 2 - 6 } & Qtde & \multicolumn{1}{c|}{$\%$} & \multicolumn{1}{c|}{ Qtde } & \multicolumn{1}{c|}{$\%$} & \multicolumn{1}{c|}{ Qtde } & \multicolumn{1}{c|}{$\%$} \\
\hline Rational & 160 & $96,4 \%$ & 6 & $3,6 \%$ & 166 & $100 \%$ \\
Idealist & 207 & $97,2 \%$ & 6 & $2,8 \%$ & 213 & $100 \%$ \\
Artisan & 31 & $96,9 \%$ & 1 & $3,1 \%$ & 32 & $100 \%$ \\
Guardian & 453 & $97,4 \%$ & 12 & $2,6 \%$ & 465 & $100 \%$ \\
Total & 851 & $97,1 \%$ & 25 & $2,9 \%$ & 876 & $100 \%$ \\
\hline
\end{tabular}

Quadro 125 - Tabela Cruzada: Os 4 Temperamentos vs. Previdência

Chi-Square Tests

\begin{tabular}{|c|c|c|c|}
\hline & Value & df & $\begin{array}{l}\text { Asymp. Sig. } \\
\text { (2-sided) }\end{array}$ \\
\hline Pearson Chi-Square & ,481 & 3 & ,923 \\
\hline $\mathrm{N}$ of Valid Cases & 876 & & \\
\hline
\end{tabular}

Quadro 126 - Teste Qui-Quadrado: Os 4 Temperamentos vs. Previdência

Teste qui-quadrado: Não há evidências que permitam rejeitar a hipótese nula de não associação das variáveis, ou seja, as evidências indicam a independência das variáveis. 
Os 16 tipos vs. Previdência

\begin{tabular}{|c|c|c|c|c|c|c|}
\hline & \multicolumn{4}{|c|}{ Possui Previdência } & & \\
\hline & \multicolumn{2}{|c|}{ Não } & \multicolumn{2}{|c|}{ Sim } & \multicolumn{2}{|c|}{ Total } \\
\hline & Count & $\%$ & Count & $\%$ & Count & $\%$ \\
\hline ENFJ & 127 & $97,7 \%$ & 3 & $2,3 \%$ & 130 & $100,0 \%$ \\
\hline ENFP & 57 & $95,0 \%$ & 3 & $5,0 \%$ & 60 & $100,0 \%$ \\
\hline ENTJ & 130 & $97,0 \%$ & 4 & $3,0 \%$ & 134 & $100,0 \%$ \\
\hline ENTP & 15 & $93,8 \%$ & 1 & $6,3 \%$ & 16 & $100,0 \%$ \\
\hline ESFJ & 126 & $97,7 \%$ & 3 & $2,3 \%$ & 129 & $100,0 \%$ \\
\hline ESFP & 15 & $93,8 \%$ & 1 & $6,3 \%$ & 16 & $100,0 \%$ \\
\hline ESTJ & 258 & $97,4 \%$ & 7 & $2,6 \%$ & 265 & $100,0 \%$ \\
\hline ESTP & 12 & $100,0 \%$ & 0 &, $0 \%$ & 12 & $100,0 \%$ \\
\hline INFJ & 20 & $100,0 \%$ & 0 &, $0 \%$ & 20 & $100,0 \%$ \\
\hline INFP & 3 & $100,0 \%$ & 0 &, $0 \%$ & 3 & $100,0 \%$ \\
\hline INTJ & 13 & $92,9 \%$ & 1 & $7,1 \%$ & 14 & $100,0 \%$ \\
\hline INTP & 2 & $100,0 \%$ & 0 &, $0 \%$ & 2 & $100,0 \%$ \\
\hline ISFJ & 23 & $100,0 \%$ & 0 &, $0 \%$ & 23 & $100,0 \%$ \\
\hline ISFP & 3 & $100,0 \%$ & 0 &, $0 \%$ & 3 & $100,0 \%$ \\
\hline ISTJ & 46 & $95,8 \%$ & 2 & $4,2 \%$ & 48 & $100,0 \%$ \\
\hline ISTP & 1 & $100,0 \%$ & 0 &, $0 \%$ & 1 & $100,0 \%$ \\
\hline Total & 851 & $97,1 \%$ & 25 & $2,9 \%$ & 876 & $100,0 \%$ \\
\hline
\end{tabular}

Quadro 127 - Tabela Cruzada: 16 tipos vs. Previdência

Chi-Square Tests

\begin{tabular}{|l|r|r|c|}
\hline & Value & df & \multicolumn{1}{|c|}{$\begin{array}{c}\text { Asymp. Sig. } \\
\text { (2-sided) }\end{array}$} \\
\hline Pearson Chi-Square & 5,757 & 15 &, 984 \\
N of Valid Cases & 876 & & \\
\hline
\end{tabular}

Quadro 128 - Teste Qui-Quadrado: 16 tipos vs. Previdência

Teste qui-quadrado: Não há evidências que permitam rejeitar a hipótese nula de não associação das variáveis, ou seja, as evidências indicam a independência das variáveis. 


\section{Extroversão / Introversão}

\begin{tabular}{|c|c|c|r|r|r|r|}
\hline \multirow{2}{*}{} & \multicolumn{3}{|c|}{ Possui Previdência } & \multirow{2}{*}{} \\
\cline { 2 - 7 } & \multicolumn{2}{|c|}{ Não } & \multicolumn{2}{c|}{ Sim } & \multicolumn{2}{c|}{ Total } \\
\cline { 2 - 7 } & Qtde & \multicolumn{1}{|c}{$\%$} & Qtde & $\%$ & Qtde & $\%$ \\
\hline Extroversão & 740 & $97,1 \%$ & 22 & $2,9 \%$ & 762 & $100,0 \%$ \\
Introversão & 111 & $97,4 \%$ & 3 & $2,6 \%$ & 114 & $100,0 \%$ \\
Total & 851 & $97,1 \%$ & 25 & $2,9 \%$ & 876 & $100,0 \%$ \\
\hline
\end{tabular}

Quadro 129 - Tabela Cruzada: Extroversão/Introversão vs. Previdência

Chi-Square Tests

\begin{tabular}{|c|c|c|c|}
\hline & Value & df & $\begin{array}{l}\text { Asymp. Sig. } \\
\text { (2-sided) }\end{array}$ \\
\hline Pearson Chi-Square & ,023 & 1 & 879 \\
\hline $\mathrm{N}$ of Valid Cases & 876 & & \\
\hline
\end{tabular}

Quadro 130 - Teste Qui-Quadrado: Extroversão/Introversão vs. Previdência

Teste qui-quadrado: Não há evidências que permitam rejeitar a hipótese nula de não associação das variáveis, ou seja, as evidências indicam a independência das variáveis. 
Sensação / Intuição

\begin{tabular}{|c|c|c|c|c|c|c|}
\hline \multirow{2}{*}{} & \multicolumn{3}{|c|}{ Possui Previdência } & \multicolumn{2}{c|}{} \\
\cline { 2 - 7 } & \multicolumn{2}{|c|}{ Não } & \multicolumn{2}{c|}{ Sim } & \multicolumn{2}{c|}{ Total } \\
\cline { 2 - 7 } & Qtde & $\%$ & Qtde & $\%$ & Qtde & $\%$ \\
\hline Intuição & 367 & $96,8 \%$ & 12 & $3,2 \%$ & 379 & $100 \%$ \\
Sensação & 484 & $97,4 \%$ & 13 & $2,6 \%$ & 497 & $100 \%$ \\
Total & 851 & $97,1 \%$ & 25 & $2,9 \%$ & 876 & $100 \%$ \\
\hline
\end{tabular}

Quadro 131 - Tabela Cruzada: Sensação/Intuição vs. Previdência

Chi-Square Tests

\begin{tabular}{|c|c|c|c|}
\hline & Value & $\mathrm{df}$ & $\begin{array}{l}\text { Asymp. Sig. } \\
\text { (2-sided) }\end{array}$ \\
\hline Pearson Chi-Square &, 235 & 1 & ,628 \\
\hline
\end{tabular}

Quadro 132 - Teste Qui-Quadrado: Sensação/Intuição vs. Previdência

Teste qui-quadrado: Não há evidências que permitam rejeitar a hipótese nula de não associação das variáveis, ou seja, as evidências indicam a independência das variáveis. 
Sentimento / Pensamento

\begin{tabular}{|c|c|c|c|c|c|c|}
\hline \multirow{2}{*}{} & \multicolumn{3}{|c|}{ Possui Previdência } & \multirow{2}{*}{} \\
\cline { 2 - 6 } & \multicolumn{2}{|c|}{ Não } & \multicolumn{2}{c|}{ Sim } & \multicolumn{2}{c|}{ Total } \\
\cline { 2 - 7 } & Qtde & $\%$ & Qtde & $\%$ & Qtde & $\%$ \\
\hline Sentimento & 374 & $97,4 \%$ & 10 & $2,6 \%$ & 384 & $100 \%$ \\
Pensamento & 477 & $97,0 \%$ & 15 & $3,0 \%$ & 492 & $100 \%$ \\
Total & 851 & $97,1 \%$ & 25 & $2,9 \%$ & 876 & $100 \%$ \\
\hline
\end{tabular}

Quadro 133 - Tabela Cruzada: Sentimento/Pensamento vs Previdência

Chi-Square Tests

\begin{tabular}{|c|c|c|c|}
\hline & Value & $\mathrm{df}$ & $\begin{array}{l}\text { Asymp. Sig. } \\
\text { (2-sided) }\end{array}$ \\
\hline Pearson Chi-Square & ,154 & $\overline{1}$ & ,695 \\
\hline $\mathrm{N}$ of Valid Cases & 876 & & \\
\hline
\end{tabular}

Quadro 134 - Teste Qui-Quadrado: Sentimento/Pensamento vs Previdência

Teste Qui-Quadrado: Não há evidências que permitam rejeitar a hipótese nula de não associação das variáveis, ou seja, as evidências indicam a independência das variáveis. 
Julgamento / Percepção

\begin{tabular}{|c|c|c|r|r|r|r|}
\hline \multirow{2}{*}{} & \multicolumn{4}{|c|}{ Possui Previdência } & \multirow{2}{*}{} \\
\cline { 2 - 7 } & \multicolumn{2}{|c|}{ Não } & \multicolumn{2}{c|}{ Sim } & \multicolumn{2}{c|}{ Total } \\
\cline { 2 - 7 } & Qtde & $\%$ & Qtde & $\%$ & Qtde & $\%$ \\
\hline Julgamento & 743 & $97,4 \%$ & 20 & $2,6 \%$ & 763 & $100,0 \%$ \\
Percepção & 108 & $95,6 \%$ & 5 & $4,4 \%$ & 113 & $100,0 \%$ \\
Total & 851 & $97,1 \%$ & 25 & $2,9 \%$ & 876 & $100,0 \%$ \\
\hline
\end{tabular}

Quadro 135 - Tabela Cruzada: Julgamento/Percepção vs. Previdência

Chi-Square Tests

\begin{tabular}{|c|c|c|c|}
\hline & Value & $\mathrm{df}$ & $\begin{array}{l}\text { Asymp. Sig. } \\
\text { (2-sided) }\end{array}$ \\
\hline Pearson Chi-Square & 1,155 & 1 & ,283 \\
\hline $\mathrm{N}$ of Valid Cases & 876 & & \\
\hline
\end{tabular}

Quadro 136 - Teste Qui-Quadrado: Julgamento/Percepção vs. Previdência

Teste Qui-Quadrado: Não há evidências que permitam rejeitar a hipótese nula de não associação das variáveis, ou seja, as evidências indicam a independência das variáveis. 


\subsubsection{Renegociação de Crédito}

Os 4 Temperamentos vs. Renegociação de Crédito

\begin{tabular}{|c|c|c|c|c|c|c|}
\hline & \multicolumn{4}{|c|}{ Possui Créditos Renegociados } & \multirow{2}{*}{\multicolumn{2}{|c|}{ Total }} \\
\hline & \multicolumn{2}{|c|}{ Não } & \multicolumn{2}{|c|}{ Sim } & & \\
\hline & Qtde & $\%$ & Qtde & $\%$ & Qtde & $\%$ \\
\hline Rational & 160 & $96,4 \%$ & 6 & $3,6 \%$ & 166 & $100,0 \%$ \\
\hline Idealist & 200 & $93,9 \%$ & 13 & $6,1 \%$ & 213 & $100,0 \%$ \\
\hline Artisan & 28 & $87,5 \%$ & 4 & $12,5 \%$ & 32 & $100,0 \%$ \\
\hline Guardian & 428 & $92,0 \%$ & 37 & $8,0 \%$ & 465 & $100,0 \%$ \\
\hline Total & 816 & $93,2 \%$ & 60 & $6,8 \%$ & 876 & $100,0 \%$ \\
\hline
\end{tabular}

Quadro 137 - Tabela Cruzada: Os 4 Temperamentos vs. Créditos Renegociados

Chi-Square Tests

\begin{tabular}{|c|c|c|c|}
\hline & Value & df & $\begin{array}{l}\text { Asymp. Sig. } \\
\text { (2-sided) }\end{array}$ \\
\hline Pearson Chi-Square & 5,404 & 3 & ,144 \\
\hline $\mathrm{N}$ of Valid Cases & 876 & & \\
\hline
\end{tabular}

Quadro 138 - Teste Qui-Quadrado: Os 4 Temperamentos vs. Créditos Renegociados

Teste qui-quadrado: Não há evidências que permitam rejeitar a hipótese nula de não associação das variáveis, ou seja, as evidências indicam a independência das variáveis. 
Os 16 tipos vs. Renegociação de Crédito

\begin{tabular}{|c|r|r|r|r|r|r|}
\hline \multirow{2}{*}{} & \multicolumn{2}{|c|}{ Possui Créditos Renegociados } & \multicolumn{2}{c|}{} \\
\cline { 2 - 6 } & \multicolumn{2}{|c|}{ Não } & \multicolumn{2}{|c|}{ Sim } & \multicolumn{2}{c|}{ Total } \\
\cline { 2 - 6 } & Qtde & \multicolumn{1}{c|}{$\%$} & Qtde & \multicolumn{1}{c|}{$\%$} & Qtde & \multicolumn{1}{c|}{$\%$} \\
\hline ENFJ & 123 & $94,6 \%$ & 7 & $5,4 \%$ & 130 & $100 \%$ \\
ENFP & 56 & $93,3 \%$ & 4 & $6,7 \%$ & 60 & $100 \%$ \\
ENTJ & 130 & $97,0 \%$ & 4 & $3,0 \%$ & 134 & $100 \%$ \\
ENTP & 15 & $93,8 \%$ & 1 & $6,3 \%$ & 16 & $100 \%$ \\
ESFJ & 117 & $90,7 \%$ & 12 & $9,3 \%$ & 129 & $100 \%$ \\
ESFP & 13 & $81,3 \%$ & 3 & $18,8 \%$ & 16 & $100 \%$ \\
ESTJ & 242 & $91,3 \%$ & 23 & $8,7 \%$ & 265 & $100 \%$ \\
ESTP & 11 & $91,7 \%$ & 1 & $8,3 \%$ & 12 & $100 \%$ \\
INFJ & 18 & $90,0 \%$ & 2 & $10,0 \%$ & 20 & $100 \%$ \\
INFP & 3 & $100 \%$ & 0 &, $0 \%$ & 3 & $100 \%$ \\
INTJ & 13 & $92,9 \%$ & 1 & $7,1 \%$ & 14 & $100 \%$ \\
INTP & 2 & $100 \%$ & 0 &, $0 \%$ & 2 & $100 \%$ \\
ISFJ & 23 & $100 \%$ & 0 &, $0 \%$ & 23 & $100 \%$ \\
ISFP & 3 & $100 \%$ & 0 &, $0 \%$ & 3 & $100 \%$ \\
ISTJ & 46 & $95,8 \%$ & 2 & $4,2 \%$ & 48 & $100 \%$ \\
ISTP & 1 & $100 \%$ & 0 &, $0 \%$ & 1 & $100 \%$ \\
Total & 816 & $93,2 \%$ & 60 & $6,8 \%$ & 876 & $100 \%$ \\
\hline
\end{tabular}

Quadro 139 - - Tabela Cruzada: 16 tipos vs. Créditos Renegociados

Chi-Square Tests

\begin{tabular}{|l|c|c|c|}
\hline & Value & df & \multicolumn{1}{|c|}{$\begin{array}{c}\text { Asymp. Sig. } \\
\text { (2-sided) }\end{array}$} \\
\hline Pearson Chi-Square & 12,993 & 15 &, 603 \\
$N$ of Valid Cases & 876 & & \\
\hline
\end{tabular}

Quadro 140 - Teste Qui-Quadrado: 16 tipos vs. Créditos Renegociados

Teste Qui-Quadrado: Não há evidências que permitam rejeitar a hipótese nula de não associação das variáveis, ou seja, as evidências indicam a independência das variáveis. 
As Dimensões dos Temperamentos vs. Renegociação de Crédito.

\section{Extroversão / Introversão}

\begin{tabular}{|c|c|c|r|r|r|c|}
\hline \multirow{2}{*}{} & \multicolumn{3}{|c|}{ Possui Créditos Renegociados } & \multirow{2}{*}{} \\
\cline { 2 - 6 } & \multicolumn{2}{|c|}{ Não } & \multicolumn{2}{c|}{ Sim } & \multicolumn{2}{c|}{ Total } \\
\cline { 2 - 7 } & Qtde & \multicolumn{1}{c|}{$\%$} & Qtde & $\%$ & Qtde & $\%$ \\
\hline Extroversão & 707 & $92,8 \%$ & 55 & $7,2 \%$ & 762 & $100 \%$ \\
Introversão & 109 & $95,6 \%$ & 5 & $4,4 \%$ & 114 & $100 \%$ \\
Total & 816 & $93,2 \%$ & 60 & $6,8 \%$ & 876 & $100 \%$ \\
\hline
\end{tabular}

Quadro 141 - Tabela Cruzada: Extroversão/Introversão vs. Créditos Renegociados

Chi-Square Tests

\begin{tabular}{|l|r|r|r|}
\hline & Value & df & $\begin{array}{c}\text { Asymp. Sig. } \\
\text { (2-sided) }\end{array}$ \\
\hline Pearson Chi-Square & 1,246 & 1 &, 264 \\
N of Valid Cases & 876 & & \\
\hline
\end{tabular}

Quadro 142 - Teste Qui-Quadrado: Extroversão/Introversão vs. Créditos Renegociados

Teste Qui-Quadrado: Não há evidências que permitam rejeitar a hipótese nula de não associação das variáveis, ou seja, as evidências indicam a independência das variáveis. 
Sensação / Intuição

\begin{tabular}{|c|c|c|r|r|r|c|}
\hline \multirow{2}{*}{} & \multicolumn{3}{|c|}{ Possui Créditos Renegociados } & \multirow{2}{*}{} \\
\cline { 2 - 6 } & \multicolumn{2}{|c|}{ Não } & \multicolumn{2}{c|}{ Sim } & \multicolumn{2}{c|}{ Total } \\
\cline { 2 - 7 } & Qtde & \multicolumn{1}{c|}{$\%$} & Qtde & $\%$ & Qtde & $\%$ \\
\hline Intuição & 360 & $95,0 \%$ & 19 & $5,0 \%$ & 379 & $100,0 \%$ \\
Sensação & 456 & $91,8 \%$ & 41 & $8,2 \%$ & 497 & $100,0 \%$ \\
Total & 816 & $93,2 \%$ & 60 & $6,8 \%$ & 876 & $100,0 \%$ \\
\hline
\end{tabular}

Quadro 143 - Tabela Cruzada: Sensação/Intuição vs. Créditos Renegociados

Chi-Square Tests

\begin{tabular}{|c|c|c|c|}
\hline & Value & df & $\begin{array}{c}\text { Asymp. Sig. } \\
\text { (2-sided) }\end{array}$ \\
\hline Pearson Chi-Square & 3,530 & $\overline{1}$ & ,060 \\
\hline $\mathrm{N}$ of Valid Cases & 876 & & \\
\hline
\end{tabular}

Quadro 144 - Teste Qui-Quadrado: Sensação/Intuição vs. Créditos Renegociados

Teste Qui-Quadrado: Não há evidências que permitam rejeitar a hipótese nula de não associação das variáveis, ou seja, as evidências indicam a independência das variáveis. 


\section{Sentimento / Pensamento}

\begin{tabular}{|c|r|c|r|r|r|c|}
\hline \multirow{2}{*}{} & \multicolumn{3}{|c|}{ Possui Créditos Renegociados } & \multirow{2}{*}{} \\
\cline { 2 - 6 } & \multicolumn{2}{|c|}{ Não } & \multicolumn{2}{c|}{ Sim } & \multicolumn{2}{c|}{ Total } \\
\cline { 2 - 6 } & Qtde & \multicolumn{1}{c|}{$\%$} & Qtde & $\%$ & Qtde & $\%$ \\
\hline Sentimento & 356 & $92,7 \%$ & 28 & $7,3 \%$ & 384 & $100 \%$ \\
Pensamento & 460 & $93,5 \%$ & 32 & $6,5 \%$ & 492 & $100 \%$ \\
Total & 816 & $93,2 \%$ & 60 & $6,8 \%$ & 876 & $100 \%$ \\
\hline
\end{tabular}

Quadro 145 - Tabela Cruzada: Sentimento/Pensamento vs. Créditos Renegociados

Chi-Square Tests

\begin{tabular}{|c|c|c|c|}
\hline & Value & $\mathrm{df}$ & $\begin{array}{c}\text { Asymp. Sig. } \\
\text { (2-sided) }\end{array}$ \\
\hline Pearson Chi-Square & ,210 & 1 & ,647 \\
\hline $\mathrm{N}$ of Valid Cases & 876 & & \\
\hline
\end{tabular}

Figura 39 - Teste Qui-Quadrado: Sentimento/Pensamento vs. Créditos Renegociados

Teste Qui-Quadrado: Não há evidências que permitam rejeitar a hipótese nula de não associação das variáveis, ou seja, as evidências indicam a independência das variáveis. 
Julgamento / Percepção

\begin{tabular}{|c|c|c|r|c|c|c|}
\hline \multirow{2}{*}{} & \multicolumn{3}{|c|}{ Possui Créditos Renegociados } & \multicolumn{2}{c|}{} \\
\cline { 2 - 7 } & \multicolumn{2}{|c|}{ Não } & \multicolumn{2}{c|}{ Sim } & \multicolumn{2}{c|}{ Total } \\
\cline { 2 - 7 } & Qtde & \multicolumn{1}{c|}{$\%$} & Qtde & $\%$ & Qtde & $\%$ \\
\hline Julgamento & 712 & $93,3 \%$ & 51 & $6,7 \%$ & 763 & $100 \%$ \\
Percepção & 104 & $92,0 \%$ & 9 & $8,0 \%$ & 113 & $100 \%$ \\
Total & 816 & $93,2 \%$ & 60 & $6,8 \%$ & 876 & $100 \%$ \\
\hline
\end{tabular}

Quadro 146 - Tabela Cruzada: Julgamento/Percepção vs. Créditos Renegociados

Chi-Square Tests

\begin{tabular}{|c|c|c|c|}
\hline & Value & df & $\begin{array}{c}\text { Asymp. Sig. } \\
\text { (2-sided) }\end{array}$ \\
\hline Pearson Chi-Square & 253 & $\overline{1}$ & 615 \\
\hline $\mathrm{N}$ of Valid Cases & 876 & & \\
\hline
\end{tabular}

Quadro 147 - Teste Qui-Quadrado: Julgamento/Percepção vs. Créditos Renegociados

Teste Qui-Quadrado: Não há evidências que permitam rejeitar a hipótese nula de não associação das variáveis, ou seja, as evidências indicam a independência das variáveis. 


\subsubsection{Conclusões Relevantes dos Temperamentos vs. Perfil da Base}

As variáveis demográficas indicaram algumas evidências de relações de perfil psicológico com sexo e idade. Os homens apresentaram-se mais como Pensamento enquanto as mulheres como Sentimento. Mesmo considerando que a amostra é de indivíduos mais jovens, observa-se que entre os mais "maduros" aumenta a incidência de perfil Sensação.

Os indivíduos "extrovertidos" apresentam tendência ao consumo, pois apresentam associação com a utilização de produtos de crédito como Cheque Especial, Empréstimos/Financiamentos e Cartão de Crédito. 


\subsection{Relação Temperamentos vs. Comportamento de Cartão de Crédito}

Objetivo: Avaliar o grau de relacionamento entre o comportamento de utilização de Cartão de Crédito e os Tipos Psicológicos.

As primeiras investigações formuladas neste item são: Qual o comportamento padrão de utilização de Cartão de Crédito? Existem características da utilização dessa modalidade de crédito que permitem criar nichos de comportamento? Existem grupos distintos pelo comportamento de uso do cartão dentro de uma mesma amostra? Esses grupos com comportamento financeiro distinto são também diferentes em tipologia psicológica?

Para definição de padrões de comportamento de utilização do crédito, buscou-se uma metodologia que investiga como e quanto os indivíduos são semelhantes ou distintos uns dos outros. Pode-se entender "comportamento comum" como o comportamento homogêneo de um mesmo grupo. Por esta linha de raciocínio, a metodologia escolhida para essa fase da investigação foi um estudo de segmentação de casos, com base nas suas características de relacionamento com o produto cartão de crédito.

O estudo de segmentação foi elaborado através de Análise de Cluster, nome de um grupo de técnicas multivariadas, cuja principal finalidade é agrupar objetos com base em suas características. A Análise de Cluster classifica objetos de modo que cada objeto seja muito similar aos outros do segmento (HAIR, Joseph, 1995). 
$\mathrm{Na}$ análise de cluster, ou análise de conglomerados como também pode ser chamada, não há qualquer informação a priori sobre a composição do grupo ou conglomerado para qualquer de seus objetos. O raciocínio estatístico utilizado na Análise de Cluster não é dos mais rigorosos, se comparado a análise de variância, regressão, análise discriminante e análise fatorial. A maioria dos métodos de agrupamento é heurística, baseada em algoritmos (MALHOTRA; Naresh, 1999).

Dentre os processos existentes para execução da técnica, foi selecionado o método não-hierárquico, também chamado $k$-médias. No processamento deste método, os indivíduos são agrupados por aproximação ao centro de um conglomerado. Inicialmente, determina ou assume um centro de aglomerado e em seguida agrupa todos os objetos que estão a menos de um valor pré-especificado do centro.

Foram utilizadas todas as variáveis relacionadas a cartão de crédito, como os volumes de compras, volumes de rotativo (parte da fatura não paga que passa a ser incorporada em fatura posterior, acrescida de juros), quantidades de compras ou saques e número de meses que o indivíduo compra e utiliza-se do crédito rotativo num período de seis meses. As variáveis que mais distinguiram um grupo do outro foram as de número de meses com compras ou rotativo. Ou seja, um grupo pode ter efetuado compras freqüentemente nos seis meses sem ter utilizado o rotativo, enquanto outro grupo pode ter pode ter utilizado o crédito rotativo e efetuado compras em todos os seis meses analisados, sendo que os volumes de compras semestrais de ambos foram, em média, bem semelhantes (Gráfico 12 - Segmentos de Cartão de Crédito, p. 250) 
Posteriormente, foram estudadas as associações dos segmentos de cartão com o Perfil Psicológico, através de análises de associações. 
7.2.1 Segmentação dos Usuários de Cartão

Grupos resultantes da Análise de Cluster:

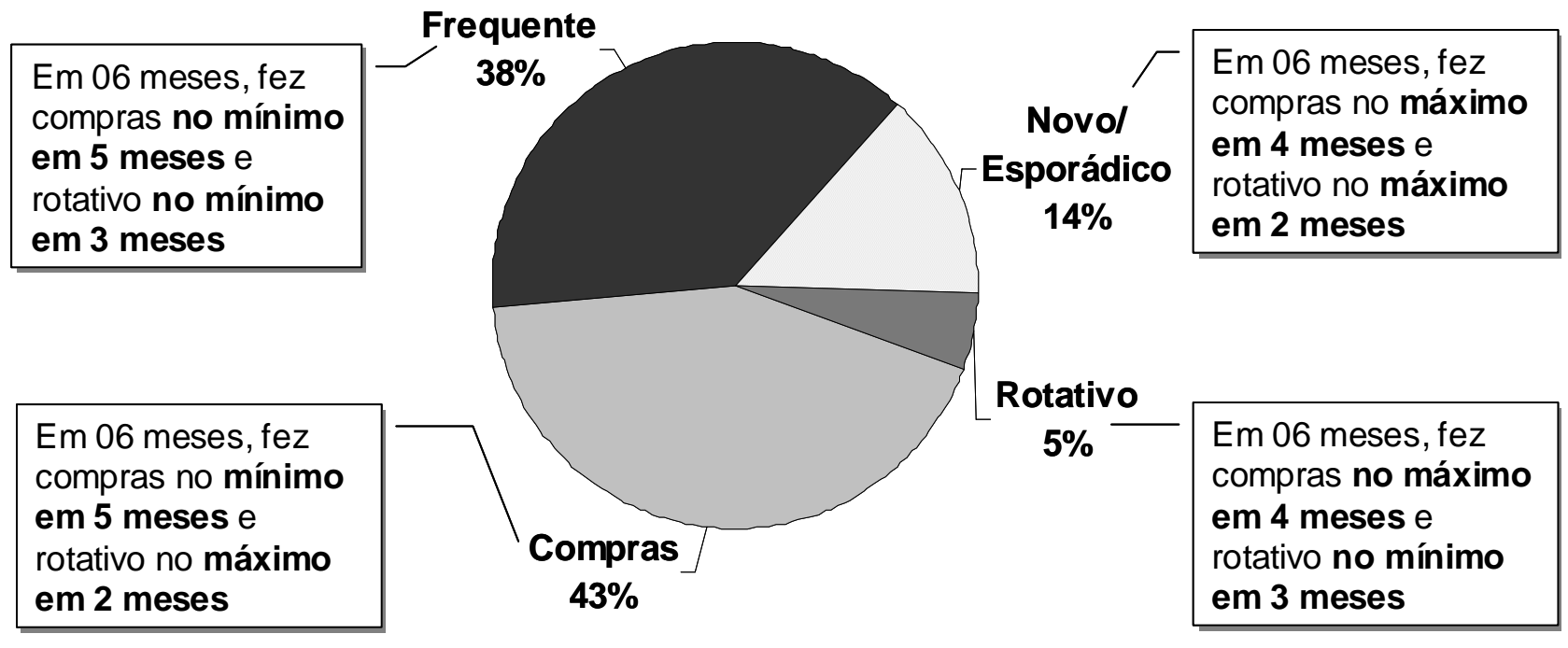

Gráfico 12 - Segmentos de Cartão de Crédito 
7.2.2 Associações entre Segmentos de Cartão de Crédito e Perfil Psicológico

Os 4 Temperamentos vs. Segmentação de Usuários de Cartão de Crédito

\begin{tabular}{|c|c|c|c|c|c|c|c|c|c|c|}
\hline & \multicolumn{8}{|c|}{ Cluster Cartão } & \multirow{2}{*}{\multicolumn{2}{|c|}{ Total }} \\
\hline & \multicolumn{2}{|c|}{$\begin{array}{c}\text { Novo/ } \\
\text { Esporádico }\end{array}$} & \multicolumn{2}{|c|}{ Rotativo } & \multicolumn{2}{|c|}{ Compras } & \multicolumn{2}{|c|}{ Frequente } & & \\
\hline & Qtde & $\%$ & Qtde & $\%$ & Qtde & $\%$ & Qtde & $\%$ & Qtde & $\%$ \\
\hline Rational & 16 & $11,9 \%$ & 5 & $3,7 \%$ & 66 & $48,9 \%$ & 48 & $35,6 \%$ & 135 & $100 \%$ \\
\hline Idealist & 29 & $16,4 \%$ & 6 & $3,4 \%$ & 76 & $42,9 \%$ & 66 & $37,3 \%$ & 177 & $100 \%$ \\
\hline Artisan & 4 & $14,3 \%$ & 1 & $3,6 \%$ & 11 & $39,3 \%$ & 12 & $42,9 \%$ & 28 & $100 \%$ \\
\hline Guardian & 56 & $14,4 \%$ & 22 & $5,6 \%$ & 157 & $40,3 \%$ & 155 & $39,7 \%$ & 390 & $100 \%$ \\
\hline Total & 105 & $14,4 \%$ & 34 & $4,7 \%$ & 310 & $42,5 \%$ & 281 & $38,5 \%$ & 730 & $100 \%$ \\
\hline
\end{tabular}

Quadro 148 - Tabela Cruzada: Os 4 Temperamentos vs. Segmentos Cartão

Chi-Square Tests

\begin{tabular}{|c|c|c|c|}
\hline & Value & $\mathrm{df}$ & $\begin{array}{c}\text { Asymp. Sig. } \\
\text { (2-sided) }\end{array}$ \\
\hline $\begin{array}{l}\text { Pearson Chi-Square } \\
\mathrm{N} \text { of Valid Cases }\end{array}$ & $\begin{array}{r}5,352 \\
730\end{array}$ & 9 & ,803 \\
\hline
\end{tabular}

Quadro 149 - Teste Qui-Quadrado: Os 4 Temperamentos vs. Segmentos Cartão

Teste Qui-Quadrado: Não há evidências que permitam rejeitar a hipótese nula de não associação das variáveis, ou seja, as evidências indicam a independência das variáveis. 
Análise Gráfica:



\section{Cluster Cartão}

Gráfico 13 - Rational vs. Segmentos Cartão

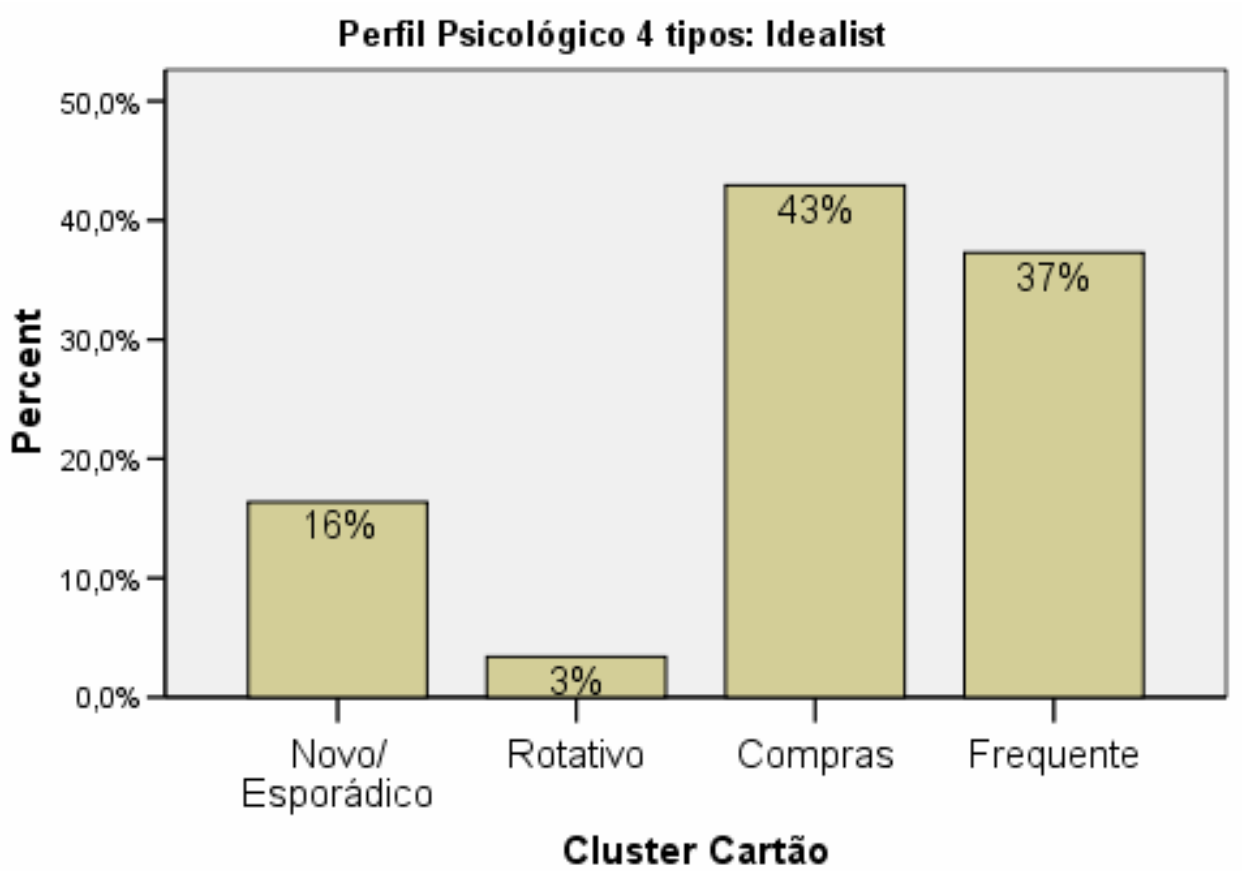

Gráfico 14 - Idealist vs. Segmentos Cartão 


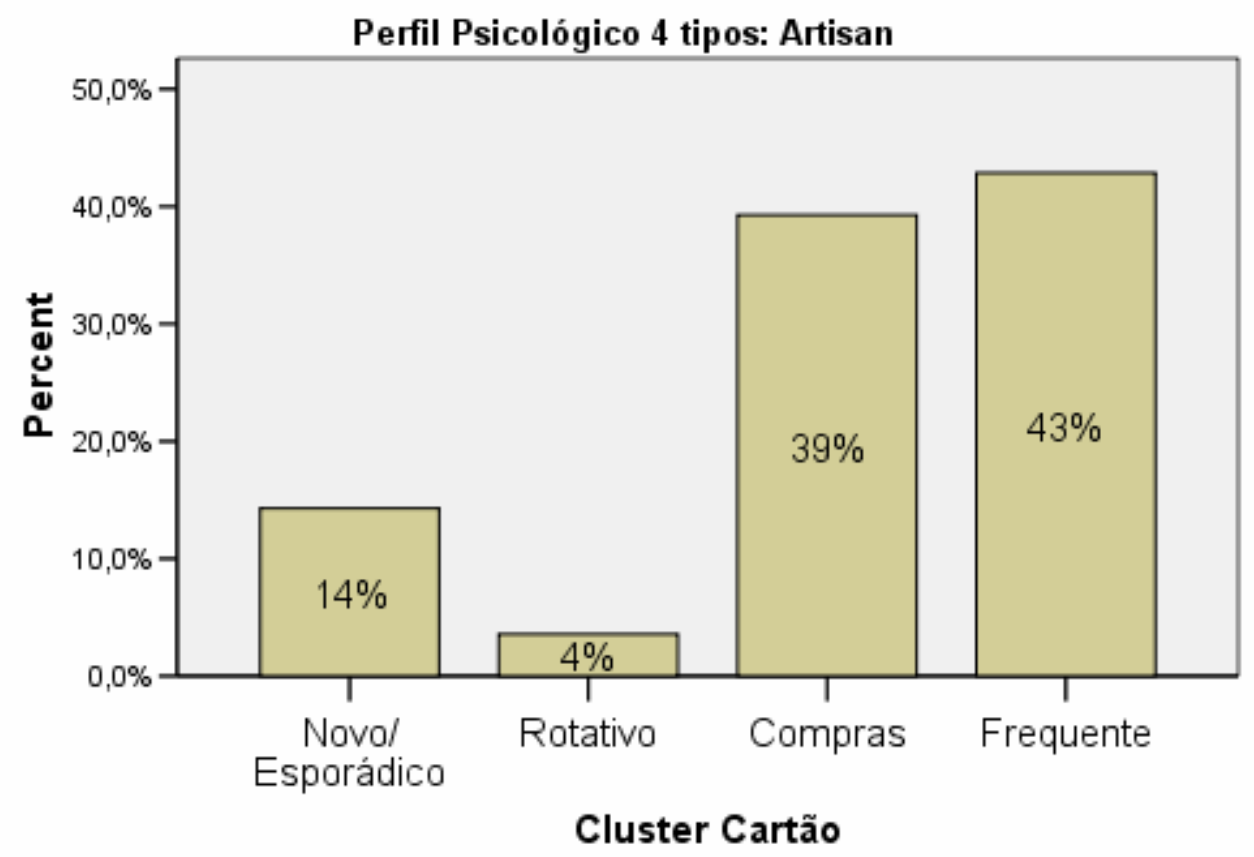

Gráfico 15 - Artisan vs. Segmentos Cartão

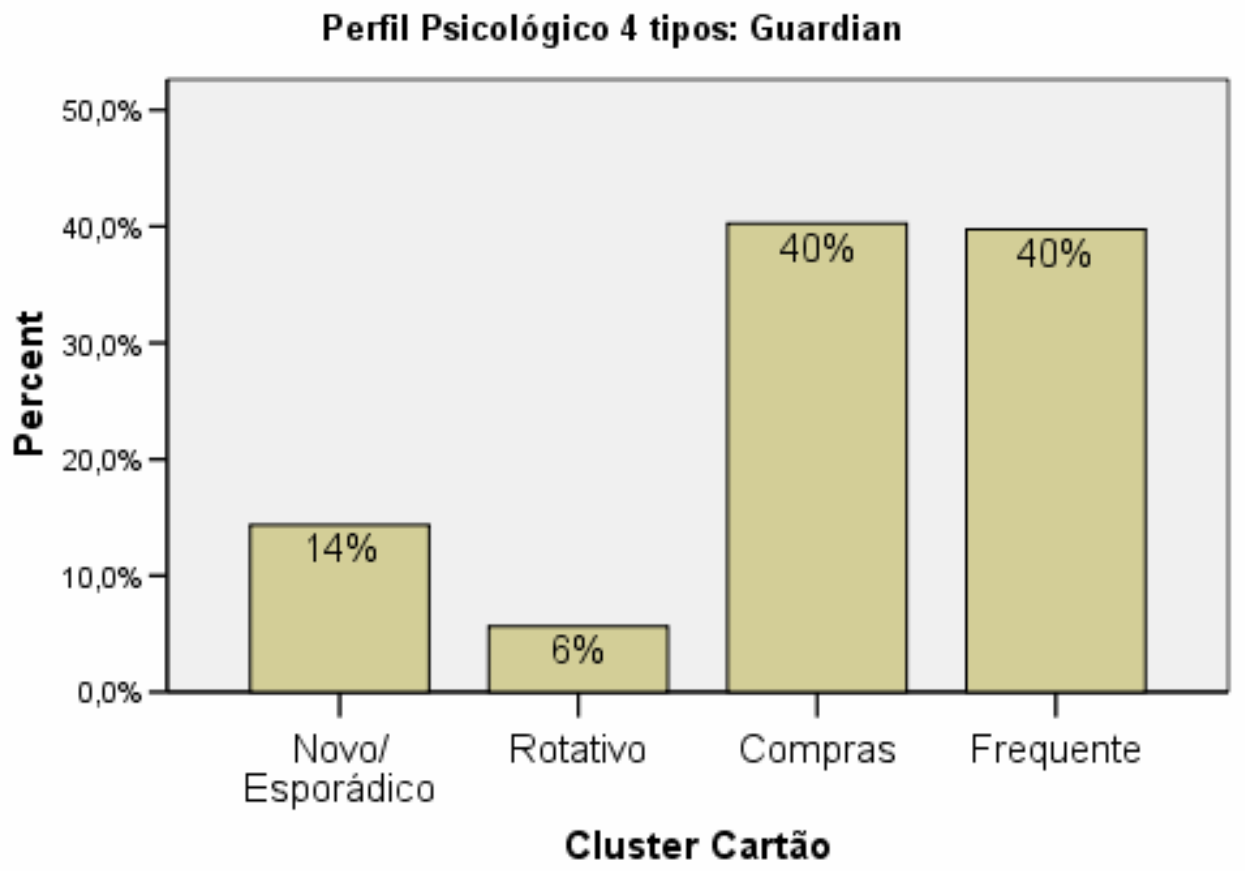

Gráfico 16 - Guardian vs. Segmentos Cartão 
Os 16 tipos vs. Segmentação de Usuários de Cartão de Crédito.

\begin{tabular}{|c|c|c|c|c|c|c|c|c|c|c|}
\hline & \multicolumn{8}{|c|}{ Cluster Cartão } & & \\
\hline & \multicolumn{2}{|c|}{$\begin{array}{c}\text { Novo/ } \\
\text { Esporádico }\end{array}$} & \multicolumn{2}{|c|}{ Rotativo } & \multicolumn{2}{|c|}{ Compras } & \multicolumn{2}{|c|}{ Frequente } & \multicolumn{2}{|c|}{ Total } \\
\hline & Qtde & $\%$ & Qtde & $\%$ & Qtde & $\%$ & Qtde & $\%$ & Qtde & $\%$ \\
\hline ENFJ & 20 & $18,3 \%$ & 4 & $3,7 \%$ & 43 & $39,4 \%$ & 42 & $38,5 \%$ & 109 & $100 \%$ \\
\hline ENFP & 9 & $18,0 \%$ & 2 & $4,0 \%$ & 20 & $40,0 \%$ & 19 & $38,0 \%$ & 50 & $100 \%$ \\
\hline ENTJ & 15 & $13,2 \%$ & 4 & $3,5 \%$ & 56 & $49,1 \%$ & 39 & $34,2 \%$ & 114 & $100 \%$ \\
\hline ENTP & 1 & $9,1 \%$ & 0 &, $0 \%$ & 4 & $36,4 \%$ & 6 & $54,5 \%$ & 11 & $100 \%$ \\
\hline ESFJ & 22 & $20,2 \%$ & 3 & $2,8 \%$ & 42 & $38,5 \%$ & 42 & $38,5 \%$ & 109 & $100 \%$ \\
\hline ESFP & 2 & $13,3 \%$ & 0 &, $0 \%$ & 8 & $53,3 \%$ & 5 & $33,3 \%$ & 15 & $100 \%$ \\
\hline ESTJ & 28 & $12,4 \%$ & 17 & $7,5 \%$ & 89 & $39,4 \%$ & 92 & $40,7 \%$ & 226 & $100 \%$ \\
\hline ESTP & 2 & $20,0 \%$ & 0 &, $0 \%$ & 2 & $20,0 \%$ & 6 & $60,0 \%$ & 10 & $100 \%$ \\
\hline INFJ & 0 &, $0 \%$ & 0 &, $0 \%$ & 13 & $72,2 \%$ & 5 & $27,8 \%$ & 18 & $100 \%$ \\
\hline INTJ & 0 &, $0 \%$ & 1 & $11,1 \%$ & 5 & $55,6 \%$ & 3 & $33,3 \%$ & 9 & $100 \%$ \\
\hline INTP & 0 &, $0 \%$ & 0 & , $0 \%$ & 1 & $100 \%$ & 0 &, $0 \%$ & 1 & $100 \%$ \\
\hline ISFJ & 0 &, $0 \%$ & 2 & $11,8 \%$ & 7 & $41,2 \%$ & 8 & $47,1 \%$ & 17 & $100 \%$ \\
\hline ISFP & 0 &, $0 \%$ & 1 & $50,0 \%$ & 1 & $50,0 \%$ & 0 &, $0 \%$ & 2 & $100 \%$ \\
\hline ISTJ & 6 & $15,8 \%$ & 0 &, $0 \%$ & 19 & $50,0 \%$ & 13 & $34,2 \%$ & 38 & $100 \%$ \\
\hline ISTP & 0 &, $0 \%$ & 0 &, $0 \%$ & 0 &, $0 \%$ & 1 & $100 \%$ & 1 & $100 \%$ \\
\hline Total & 105 & $14,4 \%$ & 34 & $4,7 \%$ & 310 & $42,5 \%$ & 281 & $38,5 \%$ & 730 & $100 \%$ \\
\hline
\end{tabular}

Quadro 150 - Tabela Cruzada: 16 tipos vs. Segmentos Cartão

Chi-Square Tests

\begin{tabular}{|l|r|r|r|}
\hline & Value & df & \multicolumn{1}{|c|}{$\begin{array}{c}\text { Asymp. Sig. } \\
\text { (2-sided) }\end{array}$} \\
\hline Pearson Chi-Square & 49,705 & 42 &, 193 \\
N of Valid Cases & 730 & & \\
\hline
\end{tabular}

Quadro 151 - Teste Qui-Quadrado: As 16 tipos vs. Segmentos Cartão

Teste Qui-Quadrado: Não há evidências que permitam rejeitar a hipótese nula de não associação das variáveis, ou seja, as evidências indicam a independência das variáveis. 
As Dimensões dos Temperamentos vs. Segmentação de Usuários de Cartão de Crédito.

\section{Extroversão / Introversão}

\begin{tabular}{|c|c|c|c|c|c|c|c|c|c|c|}
\hline & \multicolumn{8}{|c|}{ Cluster Cartão } & & \\
\hline & \multicolumn{2}{|c|}{$\begin{array}{c}\text { Novo/ } \\
\text { Esporádico }\end{array}$} & \multicolumn{2}{|c|}{ Rotativo } & \multicolumn{2}{|c|}{ Compras } & \multicolumn{2}{|c|}{ Frequente } & \multicolumn{2}{|c|}{ Total } \\
\hline & Qtde & $\%$ & Qtde & $\%$ & Qtde & $\%$ & Qtde & $\%$ & Qtde & $\%$ \\
\hline Extroversão & 99 & $15,4 \%$ & 30 & $4,7 \%$ & 264 & $41,0 \%$ & 251 & $39,0 \%$ & 644 & $100 \%$ \\
\hline Introversão & 6 & $7,0 \%$ & 4 & $4,7 \%$ & 46 & $53,5 \%$ & 30 & $34,9 \%$ & 86 & $100 \%$ \\
\hline Total & 105 & $14,4 \%$ & 34 & $4,7 \%$ & 310 & $42,5 \%$ & 281 & $38,5 \%$ & 730 & $100 \%$ \\
\hline
\end{tabular}

Quadro 152 - Tabela Cruzada: Extroversão/Introversão vs. Segmentos Cartão

Chi-Square Tests

\begin{tabular}{|c|c|c|c|}
\hline & Value & $\mathrm{df}$ & $\begin{array}{l}\text { Asymp. Sig. } \\
\text { (2-sided) }\end{array}$ \\
\hline $\begin{array}{l}\text { Pearson Chi-Square } \\
\mathrm{N} \text { of Valid Cases }\end{array}$ & $\begin{array}{r}6,837 \\
730\end{array}$ & 3 & ,077 \\
\hline
\end{tabular}

Quadro 153 - Teste Qui-Quadrado: Extroversão/Introversão vs. Segmentos Cartão

Teste Qui-Quadrado: Não há evidências que permitam rejeitar a hipótese nula de não associação das variáveis, ou seja, as evidências indicam a independência das variáveis. 
Sensação / Intuição

Crosstab

\begin{tabular}{|c|c|c|c|c|c|c|c|c|c|c|}
\hline & \multicolumn{8}{|c|}{ Cluster Cartão } & \multirow{2}{*}{\multicolumn{2}{|c|}{ Total }} \\
\hline & \multicolumn{2}{|c|}{$\begin{array}{c}\text { Novo/ } \\
\text { Esporádico }\end{array}$} & \multicolumn{2}{|c|}{ Rotativo } & \multicolumn{2}{|c|}{ Compras } & \multicolumn{2}{|c|}{ Frequente } & & \\
\hline & Qtde & $\%$ & Qtde & $\%$ & Qtde & $\%$ & Qtde & $\%$ & Qtde & $\%$ \\
\hline Intuição & 45 & $14,4 \%$ & 11 & $3,5 \%$ & 142 & $45,5 \%$ & 114 & $36,5 \%$ & 312 & $100 \%$ \\
\hline Sensação & 60 & $14,4 \%$ & 23 & $5,5 \%$ & 168 & $40,2 \%$ & 167 & $40,0 \%$ & 418 & $100 \%$ \\
\hline Total & 105 & $14,4 \%$ & 34 & $4,7 \%$ & 310 & $42,5 \%$ & 281 & $38,5 \%$ & 730 & $100 \%$ \\
\hline
\end{tabular}

Quadro 154 - Tabela Cruzada: Sensação/Intuição vs. Segmentos Cartão

Chi-Square Tests

\begin{tabular}{|c|c|c|c|}
\hline & Value & df & $\begin{array}{l}\text { Asymp. Sig. } \\
\text { (2-sided) }\end{array}$ \\
\hline $\begin{array}{l}\text { Pearson Chi-Square } \\
\mathrm{N} \text { of Valid Cases }\end{array}$ & $\begin{array}{r}3,232 \\
730\end{array}$ & 3 & ,357 \\
\hline
\end{tabular}

Quadro 155 - Teste Qui-Quadrado: Sensação/Intuição vs. Segmentos Cartão

Teste Qui-Quadrado: Não há evidências que permitam rejeitar a hipótese nula de não associação das variáveis, ou seja, as evidências indicam a independência das variáveis. 
Sentimento / Pensamento

\begin{tabular}{|c|c|c|c|c|c|c|c|c|c|c|}
\hline & \multicolumn{8}{|c|}{ Cluster Cartão } & \multirow{2}{*}{\multicolumn{2}{|c|}{ Total }} \\
\hline & \multicolumn{2}{|c|}{$\begin{array}{c}\text { Novo/ } \\
\text { Esporádico }\end{array}$} & \multicolumn{2}{|c|}{ Rotativo } & \multicolumn{2}{|c|}{ Compras } & \multicolumn{2}{|c|}{ Frequente } & & \\
\hline & Qtde & $\%$ & Qtde & $\%$ & Qtde & $\%$ & Qtde & $\%$ & Qtde & $\%$ \\
\hline Sentimento & 53 & $16,6 \%$ & 12 & $3,8 \%$ & 134 & $41,9 \%$ & 121 & $37,8 \%$ & 320 & $100 \%$ \\
\hline Pensamento & 52 & $12,7 \%$ & 22 & $5,4 \%$ & 176 & $42,9 \%$ & 160 & $39,0 \%$ & 410 & $100 \%$ \\
\hline Total & 105 & $14,4 \%$ & 34 & $4,7 \%$ & 310 & $42,5 \%$ & 281 & $38,5 \%$ & 730 & $100 \%$ \\
\hline
\end{tabular}

Quadro 156 - Tabela Cruzada: Sentimento/Pensamento vs. Segmento Cartão

Chi-Square Tests

\begin{tabular}{|l|r|r|c|}
\hline & Value & df & $\begin{array}{c}\text { Asymp. Sig. } \\
\text { (2-sided) }\end{array}$ \\
\hline Pearson Chi-Square & 3,004 & & 3 \\
N of Valid Cases & 730 & &, 391 \\
\hline
\end{tabular}

Quadro 157 - Teste Qui-Quadrado: Sentimento/Pensamento vs. Segmento Cartão

Teste Qui-Quadrado: Não há evidências que permitam rejeitar a hipótese nula de não associação das variáveis, ou seja, as evidências indicam a independência das variáveis. 
Julgamento / Percepção

\begin{tabular}{|c|c|c|c|c|c|c|c|c|c|c|}
\hline & \multicolumn{8}{|c|}{ Cluster Cartão } & & \\
\hline & \multicolumn{2}{|c|}{$\begin{array}{c}\text { Novo/ } \\
\text { Esporádico }\end{array}$} & \multicolumn{2}{|c|}{ Rotativo } & \multicolumn{2}{|c|}{ Compras } & \multicolumn{2}{|c|}{ Frequente } & \multicolumn{2}{|c|}{ Total } \\
\hline & Qtde & $\%$ & Qtde & $\%$ & Qtde & $\%$ & Qtde & $\%$ & Qtde & $\%$ \\
\hline Julgamento & 91 & $14,2 \%$ & 31 & $4,8 \%$ & 274 & $42,8 \%$ & 244 & $38,1 \%$ & 640 & $100 \%$ \\
\hline Percepção & 14 & $15,6 \%$ & 3 & $3,3 \%$ & 36 & $40,0 \%$ & 37 & $41,1 \%$ & 90 & $100 \%$ \\
\hline Total & 105 & $14,4 \%$ & 34 & $4,7 \%$ & 310 & $42,5 \%$ & 281 & $38,5 \%$ & 730 & $100 \%$ \\
\hline
\end{tabular}

Quadro 158 - Tabela Cruzada: Julgamento/Percepção vs. Segmentos Cartão

Chi-Square Tests

\begin{tabular}{|c|c|c|c|}
\hline & Value & df & $\begin{array}{l}\text { Asymp. Sig. } \\
\text { (2-sided) }\end{array}$ \\
\hline $\begin{array}{l}\text { Pearson Chi-Square } \\
\mathrm{N} \text { of Valid Cases }\end{array}$ & $\begin{array}{r}, 814 \\
730\end{array}$ & 3 &, 846 \\
\hline
\end{tabular}

Quadro 159 - Teste Qui-Quadrado: Julgamento/Percepção vs. Segmentos Cartão

Teste Qui-Quadrado: Não há evidências que permitam rejeitar a hipótese nula de não associação das variáveis, ou seja, as evidências indicam a independência das variáveis. 


\subsubsection{Associações entre Variáveis de Cartão de Crédito e Perfil Psicológico}

\section{Volume Médio de Compras}

Os 4 Temperamentos vs. Variáveis de Cartão de Crédito:

Análise Gráfica:

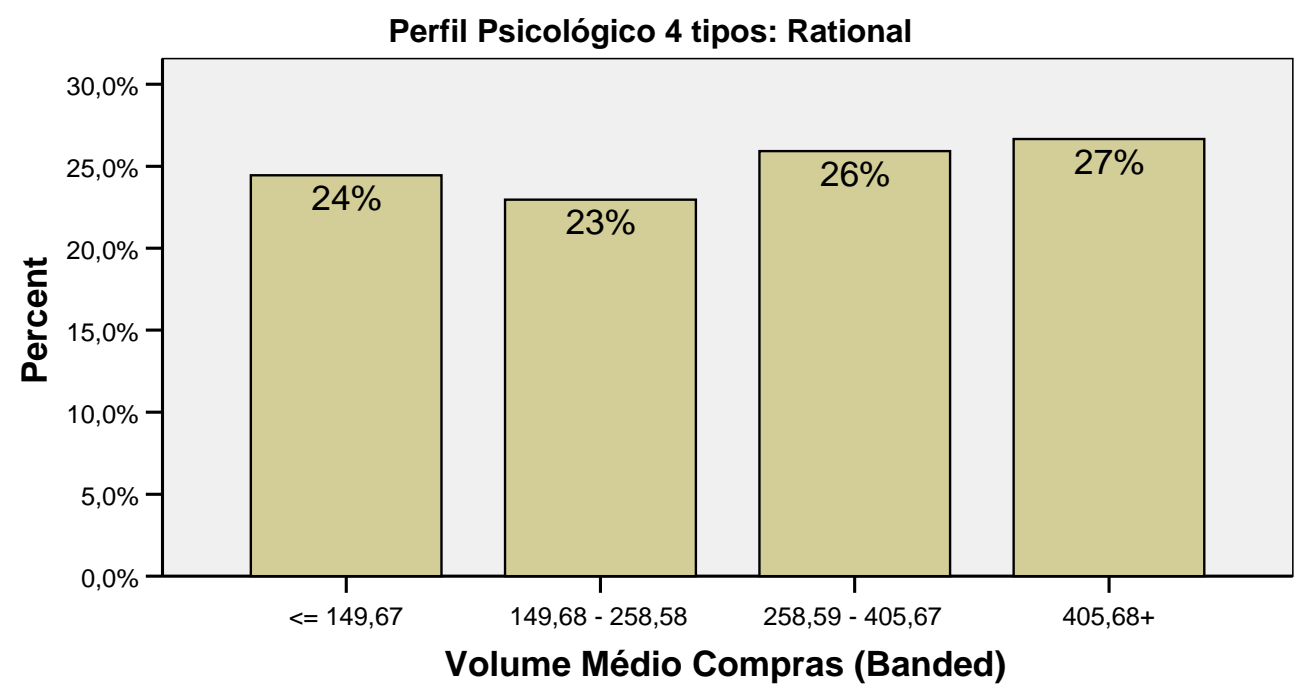

Gráfico 17 - Rationals: Volume Médio de Compras 


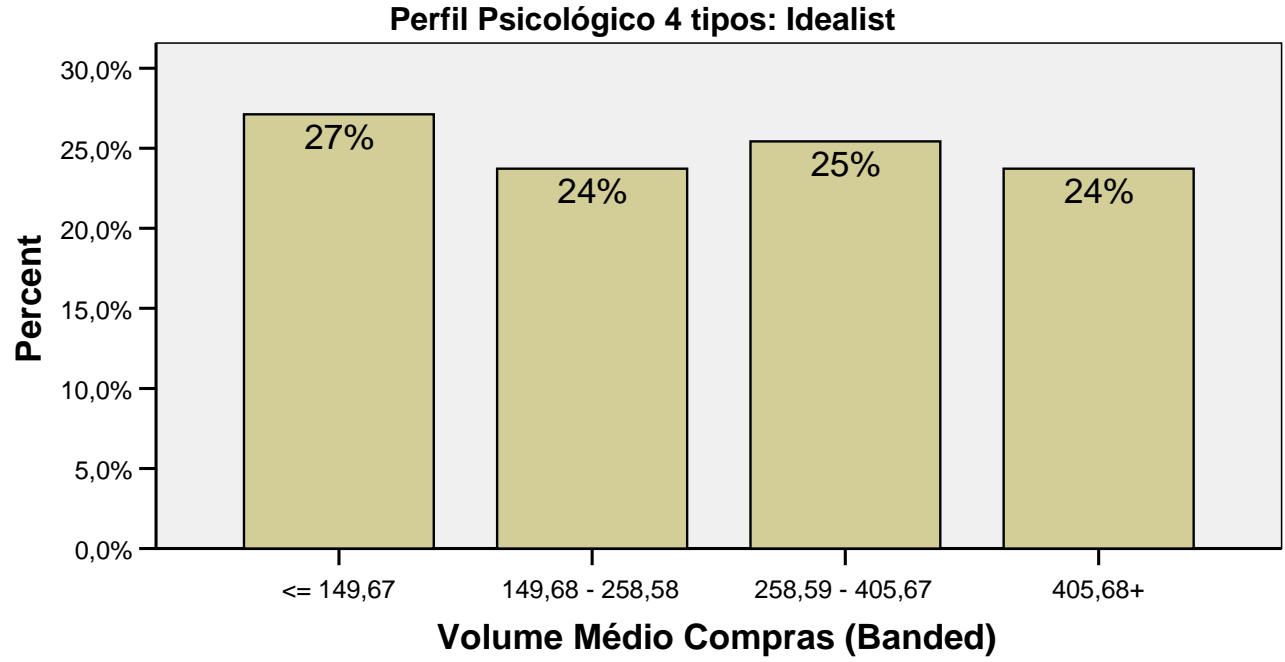

Gráfico 18 - Idealists: Volume Médio de Compras

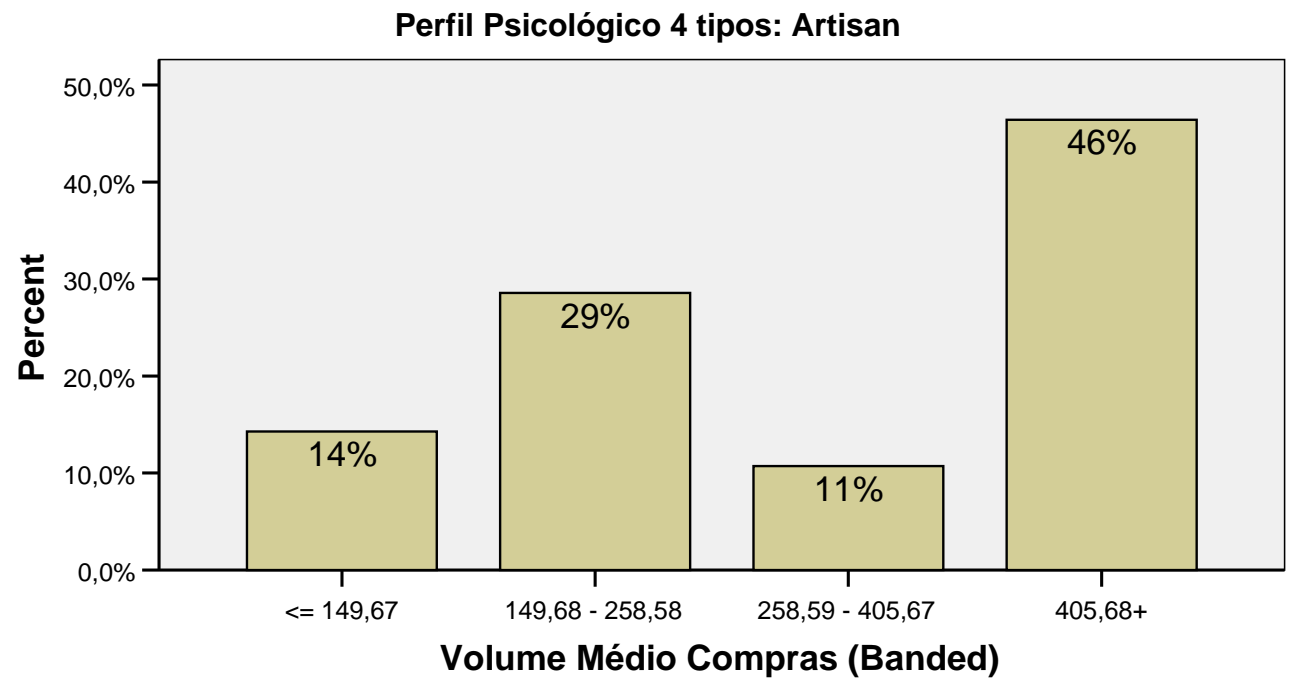

Gráfico 19 - Artisans: Volume Médio de Compras 


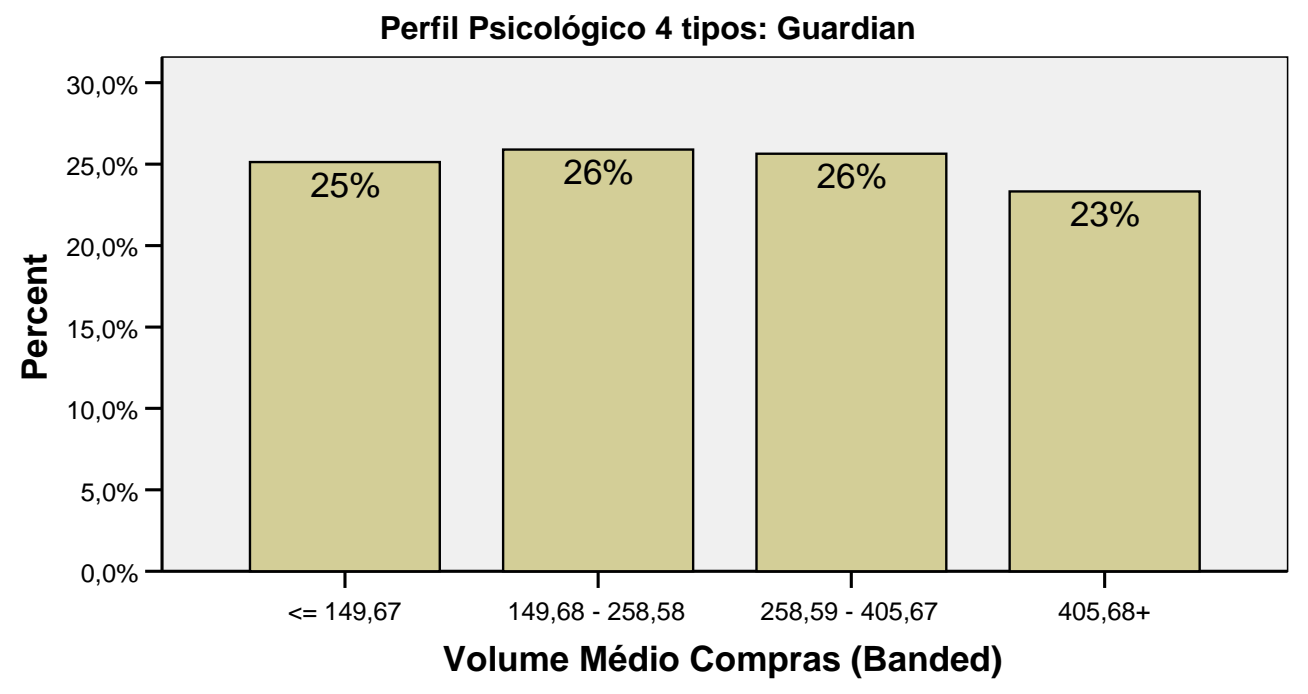

Gráfico 20 - Guardians: Volume Médio de Compras

Tabelas:

\begin{tabular}{|c|c|c|c|c|c|c|c|c|c|c|}
\hline & \multicolumn{8}{|c|}{ Volume Médio Compras (Banded) } & \multirow{2}{*}{\multicolumn{2}{|c|}{ Total }} \\
\hline & \multicolumn{2}{|c|}{$<=149,67$} & \multicolumn{2}{|c|}{$149,68-258,58$} & \multicolumn{2}{|c|}{$258,59-405,67$} & \multicolumn{2}{|c|}{$405,68+$} & & \\
\hline & Qtde & $\%$ & Qtde & $\%$ & Qtde & $\%$ & Qtde & $\%$ & Qtde & $\%$ \\
\hline Rational & 33 & $24,4 \%$ & 31 & $23,0 \%$ & 35 & $25,9 \%$ & 36 & $26,7 \%$ & 135 & $100,0 \%$ \\
\hline Idealist & 48 & $27,1 \%$ & 42 & $23,7 \%$ & 45 & $25,4 \%$ & 42 & $23,7 \%$ & 177 & $100,0 \%$ \\
\hline Artisan & 4 & $14,3 \%$ & 8 & $28,6 \%$ & 3 & $10,7 \%$ & 13 & $46,4 \%$ & 28 & $100,0 \%$ \\
\hline Guardian & 98 & $25,1 \%$ & 101 & $25,9 \%$ & 100 & $25,6 \%$ & 91 & $23,3 \%$ & 390 & $100,0 \%$ \\
\hline Total & 183 & $25,1 \%$ & 182 & $24,9 \%$ & 183 & $25,1 \%$ & 182 & $24,9 \%$ & 730 & $100,0 \%$ \\
\hline
\end{tabular}

Quadro 160 - Tabela Cruzada: Os 4 Temperamentos vs. Volumes de Compras

Chi-Square Tests

\begin{tabular}{|c|c|c|c|}
\hline & Value & $\mathrm{df}$ & $\begin{array}{l}\text { Asymp. Sig. } \\
\text { (2-sided) }\end{array}$ \\
\hline Pearson Chi-Square & 10,480 & 9 & ,313 \\
\hline
\end{tabular}

Quadro 161 - Teste Qui-quadrado: Os 4 Temperamentos vs. Volumes de Compras 
Teste Qui-Quadrado: Não há evidências que permitam rejeitar a hipótese nula de não associação das variáveis, ou seja, as evidências indicam a independência das variáveis.

Em que pese o fato da análise gráfica apresentar um comportamento distinto para os Artisans, não foi possível demonstrar-se estatisticamente essa associação. Observa-se, entretanto, que o número de Artisans presentes na amostra é bastante inferior ao dos demais temperamentos. 
As 16 tipos vs. Variáveis de Cartão de Crédito:

\begin{tabular}{|c|c|c|c|c|c|c|c|c|c|c|}
\hline & \multicolumn{8}{|c|}{ Volume Médio Compras (Banded) } & \multirow{2}{*}{\multicolumn{2}{|c|}{ Total }} \\
\hline & \multicolumn{2}{|c|}{$<=149,67$} & \multicolumn{2}{|c|}{$149,68-258,58$} & \multicolumn{2}{|c|}{$258,59-405,67$} & \multicolumn{2}{|c|}{$405,68+$} & & \\
\hline & Qtde & $\%$ & Qtde & $\%$ & Qtde & $\%$ & Qtde & $\%$ & Qtde & $\%$ \\
\hline ENFJ & 32 & $29,4 \%$ & 27 & $24,8 \%$ & 27 & $24,8 \%$ & 23 & $21,1 \%$ & 109 & $100 \%$ \\
\hline ENFP & 11 & $22,0 \%$ & 11 & $22,0 \%$ & 13 & $26,0 \%$ & 15 & $30,0 \%$ & 50 & $100 \%$ \\
\hline ENTJ & 29 & $25,4 \%$ & 27 & $23,7 \%$ & 27 & $23,7 \%$ & 31 & $27,2 \%$ & 114 & $100 \%$ \\
\hline ENTP & 2 & $18,2 \%$ & 2 & $18,2 \%$ & 4 & $36,4 \%$ & 3 & $27,3 \%$ & 11 & $100 \%$ \\
\hline ESFJ & 32 & $29,4 \%$ & 24 & $22,0 \%$ & 31 & $28,4 \%$ & 22 & $20,2 \%$ & 109 & $100 \%$ \\
\hline ESFP & 2 & $13,3 \%$ & 5 & $33,3 \%$ & 2 & $13,3 \%$ & 6 & $40,0 \%$ & 15 & $100 \%$ \\
\hline ESTJ & 54 & $23,9 \%$ & 58 & $25,7 \%$ & 58 & $25,7 \%$ & 56 & $24,8 \%$ & 226 & $100 \%$ \\
\hline ESTP & 1 & $10,0 \%$ & 3 & $30,0 \%$ & 0 &, $0 \%$ & 6 & $60,0 \%$ & 10 & $100 \%$ \\
\hline INFJ & 5 & $27,8 \%$ & 4 & $22,2 \%$ & 5 & $27,8 \%$ & 4 & $22,2 \%$ & 18 & $100 \%$ \\
\hline INTJ & 2 & $22,2 \%$ & 2 & $22,2 \%$ & 3 & $33,3 \%$ & 2 & $22,2 \%$ & 9 & $100 \%$ \\
\hline INTP & 0 &, $0 \%$ & 0 &, $0 \%$ & 1 & $100 \%$ & 0 &, $0 \%$ & 1 & $100 \%$ \\
\hline ISFJ & 3 & $17,6 \%$ & 4 & $23,5 \%$ & 2 & $11,8 \%$ & 8 & $47,1 \%$ & 17 & $100 \%$ \\
\hline ISFP & 1 & $50,0 \%$ & 0 &, $0 \%$ & 1 & $50,0 \%$ & 0 &, $0 \%$ & 2 & $100 \%$ \\
\hline ISTJ & 9 & $23,7 \%$ & 15 & $39,5 \%$ & 9 & $23,7 \%$ & 5 & $13,2 \%$ & 38 & $100 \%$ \\
\hline ISTP & 0 &, $0 \%$ & 0 &, $0 \%$ & 0 &, $0 \%$ & 1 & $100 \%$ & 1 & $100 \%$ \\
\hline Total & 183 & $25,1 \%$ & 182 & $24,9 \%$ & 183 & $25,1 \%$ & 182 & $24,9 \%$ & 730 & $100 \%$ \\
\hline
\end{tabular}

\section{Quadro 162 - Tabela Cruzada: 16 tipos vs. Volume Médio Compras}

Chi-Square Tests

\begin{tabular}{|l|r|r|c|}
\hline & Value & df & $\begin{array}{c}\text { Asymp. Sig. } \\
\text { (2-sided) }\end{array}$ \\
\hline Pearson Chi-Square & 37,324 & 42 &, 676 \\
N of Valid Cases & 730 & & 42 \\
\hline
\end{tabular}

Quadro 163 - Teste Qui-Quadrado: 16 tipos: vs. Volume Médio Compras

Teste Qui-quadrado: Não há evidências que permitam rejeitar a hipótese nula de não associação das variáveis, ou seja, as evidências indicam a independência das variáveis. 
Extroversão / Introversão:

\begin{tabular}{|c|c|c|c|c|c|c|c|c|c|c|}
\hline & \multicolumn{8}{|c|}{ Volume Médio Compras (Banded) } & \multirow{2}{*}{\multicolumn{2}{|c|}{ Total }} \\
\hline & \multicolumn{2}{|c|}{$<=149,67$} & \multicolumn{2}{|c|}{$149,68-258,58$} & \multicolumn{2}{|c|}{$258,59-405,67$} & \multicolumn{2}{|c|}{$405,68+$} & & \\
\hline & Qtde & $\%$ & Qtde & $\%$ & Qtde & $\%$ & Qtde & $\%$ & Qtde & $\%$ \\
\hline Extroversão & 163 & $25,3 \%$ & 157 & $24,4 \%$ & 162 & $25,2 \%$ & 162 & $25,2 \%$ & 644 & $100 \%$ \\
\hline Introversão & 20 & $23,3 \%$ & 25 & $29,1 \%$ & 21 & $24,4 \%$ & 20 & $23,3 \%$ & 86 & $100 \%$ \\
\hline Total & 183 & $25,1 \%$ & 182 & $24,9 \%$ & 183 & $25,1 \%$ & 182 & $24,9 \%$ & 730 & $100 \%$ \\
\hline
\end{tabular}

Quadro 164 - Tabela Cruzada: Extroversão / Introversão vs. Volume Médio de Compras

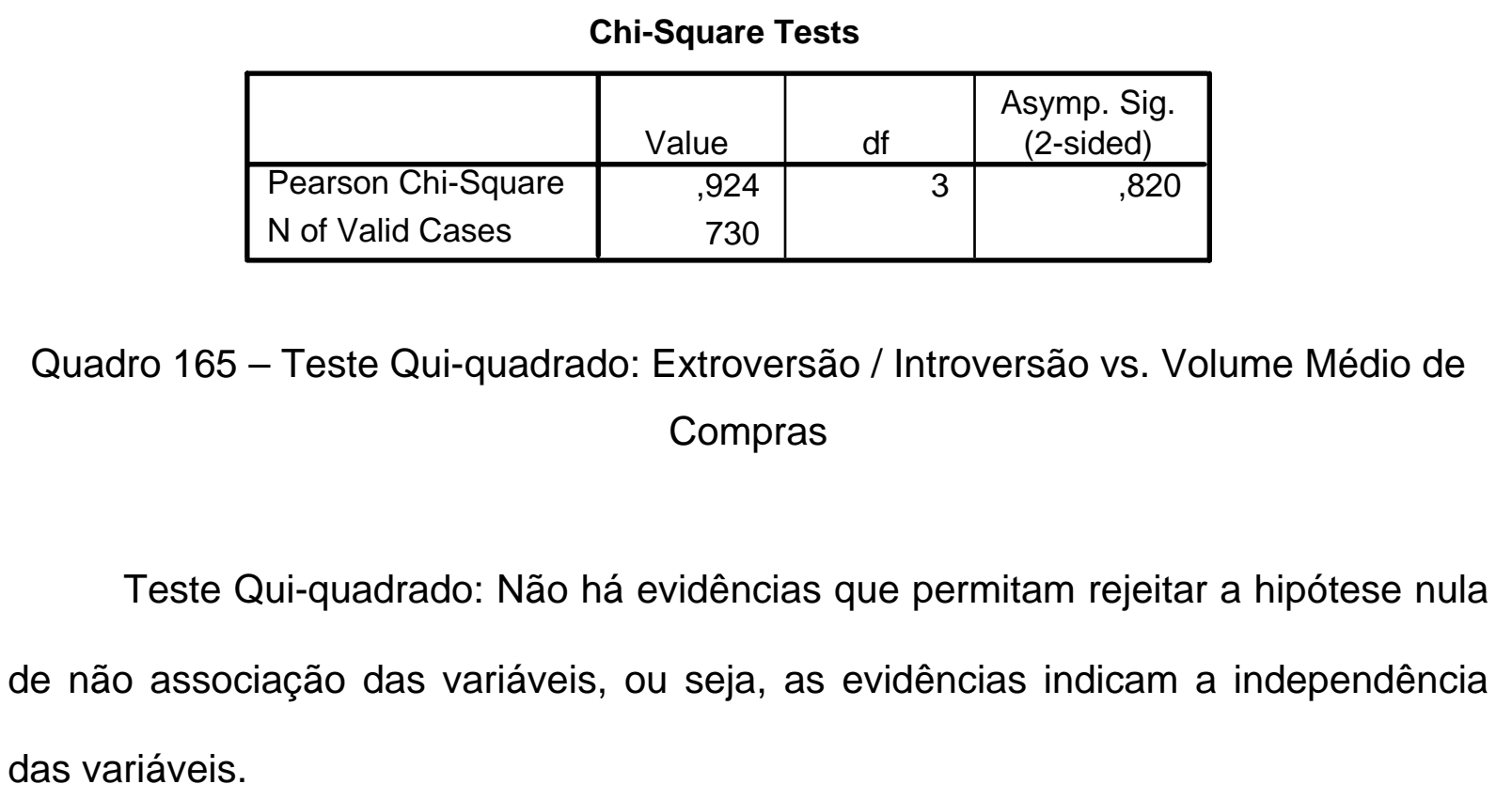


Sensação / Intuição:

\begin{tabular}{|c|c|c|c|c|c|c|c|c|c|c|}
\hline & \multicolumn{8}{|c|}{ Volume Médio Compras (Banded) } & \multirow{2}{*}{\multicolumn{2}{|c|}{ Total }} \\
\hline & \multicolumn{2}{|c|}{$<=149,67$} & \multicolumn{2}{|c|}{$149,68-258,58$} & \multicolumn{2}{|c|}{$258,59-405,67$} & \multicolumn{2}{|c|}{$405,68+$} & & \\
\hline & Qtde & $\%$ & Qtde & $\%$ & Qtde & $\%$ & Qtde & $\%$ & Qtde & $\%$ \\
\hline Intuição & 81 & $26,0 \%$ & 73 & $23,4 \%$ & 80 & $25,6 \%$ & 78 & $25,0 \%$ & 312 & $100 \%$ \\
\hline Sensação & 102 & $24,4 \%$ & 109 & $26,1 \%$ & 103 & $24,6 \%$ & 104 & $24,9 \%$ & 418 & $100 \%$ \\
\hline Total & 183 & $25,1 \%$ & 182 & $24,9 \%$ & 183 & $25,1 \%$ & 182 & $24,9 \%$ & 730 & $100 \%$ \\
\hline
\end{tabular}

Quadro 166 - Tabela Cruzada: Sensação / Intuição vs. Volume Médio de Compras

Chi-Square Tests

\begin{tabular}{|l|c|c|c|}
\hline & Value & df & $\begin{array}{c}\text { Asymp. Sig. } \\
\text { (2-sided) }\end{array}$ \\
\hline Pearson Chi-Square &, 760 & & 3 \\
N of Valid Cases & 730 & &, 859 \\
\hline
\end{tabular}

Quadro 167 - Teste Qui-quadrado: Sensação / Intuição vs. Volume Médio de Compras

Teste Qui-Quadrado: Não há evidências que permitam rejeitar a hipótese nula de não associação das variáveis, ou seja, as evidências indicam a independência das variáveis. 
Sentimento / Pensamento:

\begin{tabular}{|c|c|c|c|c|c|c|c|c|c|c|}
\hline & \multicolumn{8}{|c|}{ Volume Médio Compras (Banded) } & \multirow{2}{*}{\multicolumn{2}{|c|}{ Total }} \\
\hline & \multicolumn{2}{|c|}{$<=149,67$} & \multicolumn{2}{|c|}{$149,68-258,58$} & \multicolumn{2}{|c|}{$258,59-405,67$} & \multicolumn{2}{|c|}{$405,68+$} & & \\
\hline & Qtde & $\%$ & Qtde & $\%$ & Qtde & $\%$ & Qtde & $\%$ & Qtde & $\%$ \\
\hline Sentimento & 86 & $26,9 \%$ & 75 & $23,4 \%$ & 81 & $25,3 \%$ & 78 & $24,4 \%$ & 320 & $100 \%$ \\
\hline Pensamento & 97 & $23,7 \%$ & 107 & $26,1 \%$ & 102 & $24,9 \%$ & 104 & $25,4 \%$ & 410 & $100 \%$ \\
\hline Total & 183 & $25,1 \%$ & 182 & $24,9 \%$ & 183 & $25,1 \%$ & 182 & $24,9 \%$ & 730 & $100 \%$ \\
\hline
\end{tabular}

Quadro 168 - Tabela Cruzada: Sentimento / Pensamento vs. Volume Médio de Compras

\section{Chi-Square Tests}

\begin{tabular}{|c|c|c|c|}
\hline & Value & df & $\begin{array}{l}\text { Asymp. Sig. } \\
\text { (2-sided) }\end{array}$ \\
\hline $\begin{array}{l}\text { Pearson Chi-Square } \\
\mathrm{N} \text { of Valid Cases }\end{array}$ & $\begin{array}{r}1,336 \\
730\end{array}$ & 3 &, 721 \\
\hline
\end{tabular}

Quadro 169 - Teste Qui-Quadrado: Sentimento / Pensamento vs. Volume Médio de Compras

Teste Qui-Quadrado: Não há evidências que permitam rejeitar a hipótese nula de não associação das variáveis, ou seja, as evidências indicam a independência das variáveis. 
Julgamento / Percepção:

\begin{tabular}{|c|c|c|c|c|c|c|c|c|c|c|}
\hline & \multicolumn{8}{|c|}{ Volume Médio Compras (Banded) } & \multirow{2}{*}{\multicolumn{2}{|c|}{ Total }} \\
\hline & \multicolumn{2}{|c|}{$<=149,67$} & \multicolumn{2}{|c|}{$149,68-258,58$} & \multicolumn{2}{|c|}{$258,59-405,67$} & \multicolumn{2}{|c|}{$405,68+$} & & \\
\hline & Qtde & $\%$ & Qtde & $\%$ & Qtde & $\%$ & Qtde & $\%$ & Qtde & $\%$ \\
\hline Julgamento & 166 & $25,9 \%$ & 161 & $25,2 \%$ & 162 & $25,3 \%$ & 151 & $23,6 \%$ & 640 & $100 \%$ \\
\hline Percepção & 17 & $18,9 \%$ & 21 & $23,3 \%$ & 21 & $23,3 \%$ & 31 & $34,4 \%$ & 90 & $100 \%$ \\
\hline Total & 183 & $25,1 \%$ & 182 & $24,9 \%$ & 183 & $25,1 \%$ & 182 & $24,9 \%$ & 730 & $100 \%$ \\
\hline
\end{tabular}

Quadro 170 - Tabela Cruzada: Julgamento / Percepção vs. Volume Médio de Compras

\section{Chi-Square Tests}

\begin{tabular}{|l|r|r|r|}
\hline & Value & df & $\begin{array}{c}\text { Asymp. Sig. } \\
\text { (2-sided) }\end{array}$ \\
\hline Pearson Chi-Square & 5,518 & & 3 \\
N of Valid Cases & 730 & &, 138 \\
\hline
\end{tabular}

Quadro 171 - Tabela Cruzada: Julgamento / Percepção vs. Volume Médio de Compras

Teste Qui-quadrado: Não há evidências que permitam rejeitar a hipótese nula de não associação das variáveis, ou seja, as evidências indicam a independência das variáveis. 
Volume Médio de Rotativo

Análise Gráfica

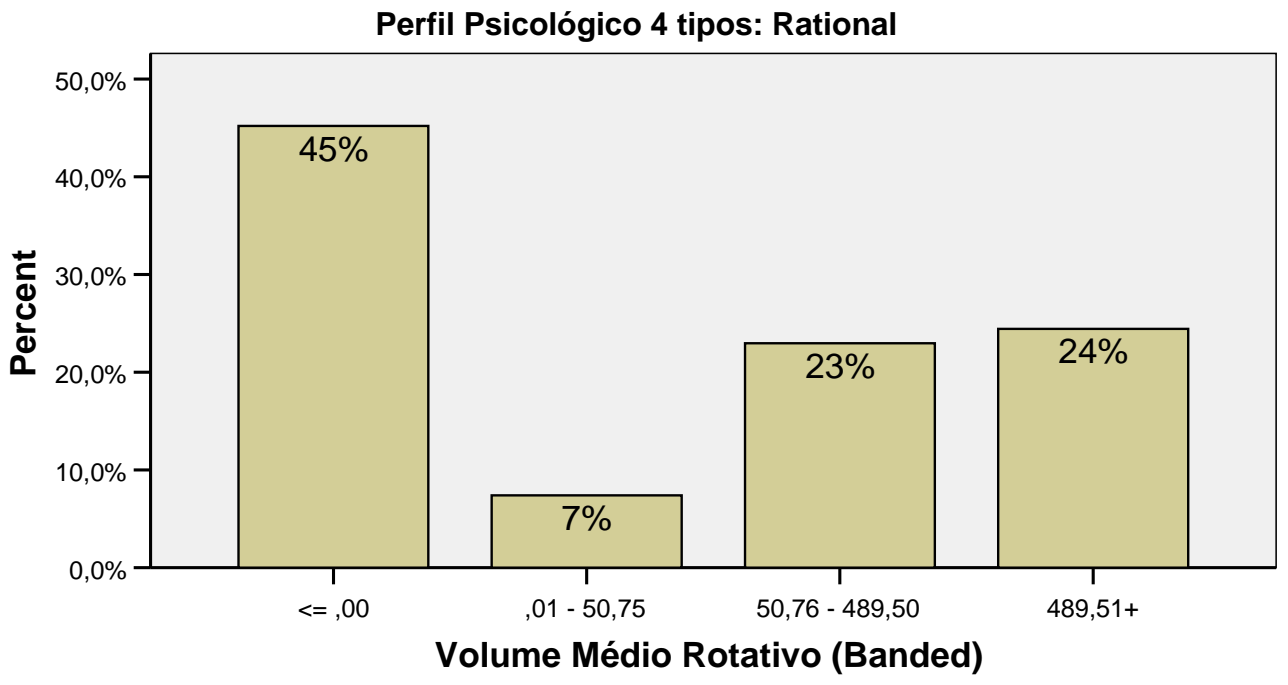

Gráfico 21 - Rational: Volume Médio de Rotativo

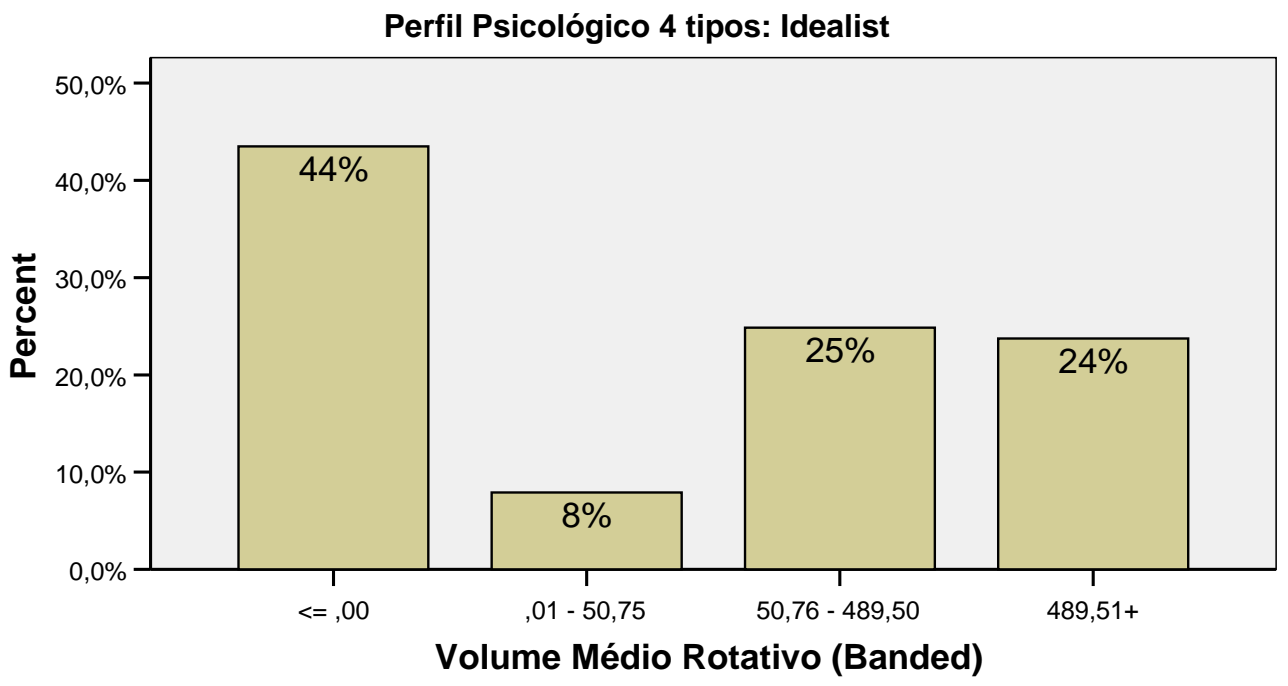

Gráfico 22 - Idealist: Volume Médio de Rotativo 


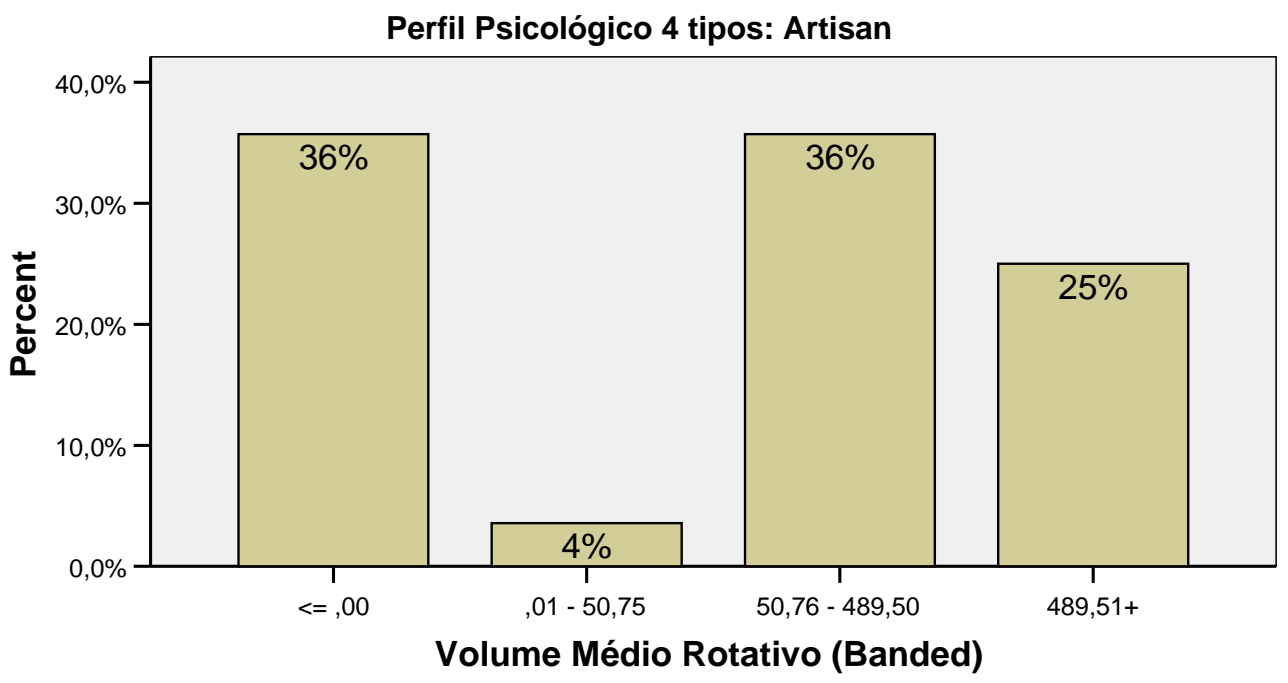

Gráfico 23 - Artisan: Volume Médio de Rotativo

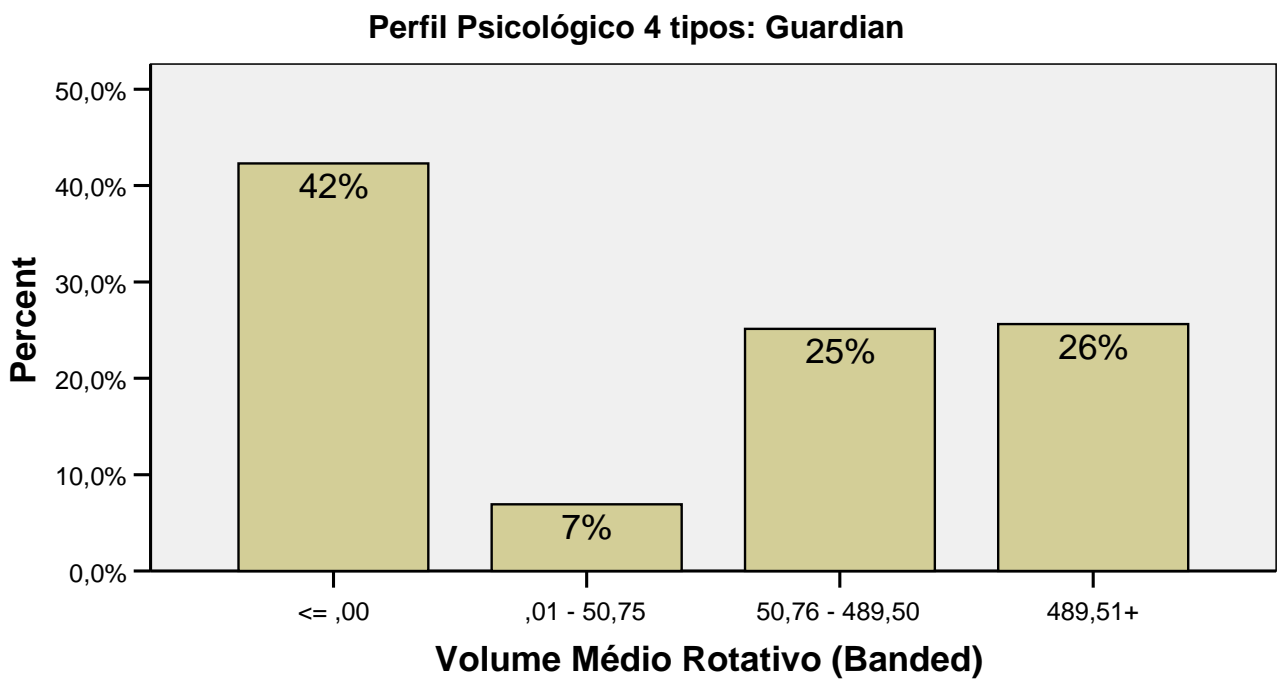

Gráfico 24 - Guardian: Volume Médio de Rotativo 
Tabelas:

\begin{tabular}{|c|c|c|c|c|c|c|c|c|c|c|}
\hline & \multicolumn{8}{|c|}{ Volume Médio Rotativo (Banded) } & \multirow{2}{*}{\multicolumn{2}{|c|}{ Total }} \\
\hline & \multicolumn{2}{|c|}{$<=, 00$} & \multicolumn{2}{|c|}{,01 - 50,75 } & \multicolumn{2}{|c|}{$50,76-489,50$} & \multicolumn{2}{|c|}{$489,51+$} & & \\
\hline & Qtde & $\%$ & Qtde & $\%$ & Qtde & $\%$ & Qtde & $\%$ & Qtde & $\%$ \\
\hline Rational & 61 & $45,2 \%$ & 10 & $7,4 \%$ & 31 & $23,0 \%$ & 33 & $24,4 \%$ & 135 & $100 \%$ \\
\hline Idealist & 77 & $43,5 \%$ & 14 & $7,9 \%$ & 44 & $24,9 \%$ & 42 & $23,7 \%$ & 177 & $100 \%$ \\
\hline Artisan & 10 & $35,7 \%$ & 1 & $3,6 \%$ & 10 & $35,7 \%$ & 7 & $25,0 \%$ & 28 & $100 \%$ \\
\hline Guardian & 165 & $42,3 \%$ & 27 & $6,9 \%$ & 98 & $25,1 \%$ & 100 & $25,6 \%$ & 390 & $100 \%$ \\
\hline Total & 313 & $42,9 \%$ & 52 & $7,1 \%$ & 183 & $25,1 \%$ & 182 & $24,9 \%$ & 730 & $100 \%$ \\
\hline
\end{tabular}

Quadro 172 - Tabela Cruzada: Os 4 Temperamentos vs. Volumes de Rotativo

Chi-Square Tests

\begin{tabular}{|c|c|c|c|}
\hline & Value & df & $\begin{array}{l}\text { Asymp. Sig. } \\
\text { (2-sided) }\end{array}$ \\
\hline $\begin{array}{l}\text { Pearson Chi-Square } \\
\mathrm{N} \text { of Valid Cases }\end{array}$ & $\begin{array}{r}2,938 \\
730\end{array}$ & $\overline{9}$ & ,967 \\
\hline
\end{tabular}

Quadro 173 - Teste Qui-Quadrado: Os 4 Temperamentos vs. Volumes de Rotativo

Teste Qui-Quadrado: Não há evidências que permitam rejeitar a hipótese nula de não associação das variáveis, ou seja, as evidências indicam a independência das variáveis.

A exemplo do ocorrido com o volume médio de compras, pode-se observar que os Artisans apresentam um comportamento distinto do ponto de vista da análise gráfica. Entretanto, o reduzido número de representantes dessa amostra provavelmente não permitiu a comprovação estatística dessa observação gráfica. 
Os 16 tipos vs. Volume de Rotativo

\begin{tabular}{|c|c|c|c|c|c|c|c|c|c|c|}
\hline & \multicolumn{8}{|c|}{ Volume Médio Rotativo (Banded) } & & \\
\hline & \multicolumn{2}{|c|}{$<=, 00$} & \multicolumn{2}{|c|}{$, 01-50,75$} & \multicolumn{2}{|c|}{$50,76-489,50$} & \multicolumn{2}{|c|}{$489,51+$} & \multicolumn{2}{|c|}{ Total } \\
\hline & Qtde & $\%$ & Qtde & $\%$ & Qtde & $\%$ & Qtde & $\%$ & Qtde & $\%$ \\
\hline$\overline{E N F J}$ & 48 & $44,0 \%$ & 9 & $8,3 \%$ & 24 & $22,0 \%$ & 28 & $25,7 \%$ & 109 & $100 \%$ \\
\hline ENFP & 23 & $46,0 \%$ & 3 & $6,0 \%$ & 11 & $22,0 \%$ & 13 & $26,0 \%$ & 50 & $100 \%$ \\
\hline ENTJ & 53 & $46,5 \%$ & 9 & $7,9 \%$ & 27 & $23,7 \%$ & 25 & $21,9 \%$ & 114 & $100 \%$ \\
\hline ENTP & 2 & $18,2 \%$ & 1 & $9,1 \%$ & 4 & $36,4 \%$ & 4 & $36,4 \%$ & 11 & $100 \%$ \\
\hline ESFJ & 49 & $45,0 \%$ & 8 & $7,3 \%$ & 25 & $22,9 \%$ & 27 & $24,8 \%$ & 109 & $100 \%$ \\
\hline ESFP & 6 & $40,0 \%$ & 1 & $6,7 \%$ & 4 & $26,7 \%$ & 4 & $26,7 \%$ & 15 & $100 \%$ \\
\hline ESTJ & 92 & $40,7 \%$ & 15 & $6,6 \%$ & 58 & $25,7 \%$ & 61 & $27,0 \%$ & 226 & $100 \%$ \\
\hline ESTP & 3 & $30,0 \%$ & 0 &, $0 \%$ & 4 & $40,0 \%$ & 3 & $30,0 \%$ & 10 & $100 \%$ \\
\hline INFJ & 6 & $33,3 \%$ & 2 & $11,1 \%$ & 9 & $50,0 \%$ & 1 & $5,6 \%$ & 18 & $100 \%$ \\
\hline INTJ & 5 & $55,6 \%$ & 0 &, $0 \%$ & 0 &, $0 \%$ & 4 & $44,4 \%$ & 9 & $100 \%$ \\
\hline INTP & 1 & $100 \%$ & 0 &, $0 \%$ & 0 &, $0 \%$ & 0 &, $0 \%$ & 1 & $100 \%$ \\
\hline ISFJ & 6 & $35,3 \%$ & 1 & $5,9 \%$ & 5 & $29,4 \%$ & 5 & $29,4 \%$ & 17 & $100 \%$ \\
\hline ISFP & 1 & $50,0 \%$ & 0 &, $0 \%$ & 1 & $50,0 \%$ & 0 &, $0 \%$ & 2 & $100 \%$ \\
\hline ISTJ & 18 & $47,4 \%$ & 3 & $7,9 \%$ & 10 & $26,3 \%$ & 7 & $18,4 \%$ & 38 & $100 \%$ \\
\hline ISTP & 0 &, $0 \%$ & 0 &, $0 \%$ & 1 & $100 \%$ & 0 &, $0 \%$ & 1 & $100 \%$ \\
\hline Total & 313 & $42,9 \%$ & 52 & $7,1 \%$ & 183 & $25,1 \%$ & 182 & $24,9 \%$ & 730 & $100 \%$ \\
\hline
\end{tabular}

Quadro 174 - Tabela Cruzada: 16 tipos vs. Volume Médio de Rotativo

Chi-Square Tests

\begin{tabular}{|l|r|r|r|}
\hline & Value & df & $\begin{array}{c}\text { Asymp. Sig. } \\
\text { (2-sided) }\end{array}$ \\
\hline Pearson Chi-Square & 27,448 & & 42 \\
N of Valid Cases & 730 & &, 960 \\
\hline
\end{tabular}

Quadro 175 - Teste Qui-quadrado: 16 tipos vs. Volume Médio de Rotativo

Teste Qui-Quadrado: Não há evidências que permitam rejeitar a hipótese nula de não associação das variáveis, ou seja, as evidências indicam a independência das variáveis. 
Extroversão / Introversão:

\begin{tabular}{|c|c|c|c|c|c|c|c|c|c|c|}
\hline & \multicolumn{8}{|c|}{ Volume Médio Rotativo (Banded) } & & \\
\hline & \multicolumn{2}{|c|}{$<=, 00$} & \multicolumn{2}{|c|}{$01-50,75$} & \multicolumn{2}{|c|}{$50,76-489,50$} & \multicolumn{2}{|c|}{$489,51+$} & \multicolumn{2}{|c|}{ Total } \\
\hline & Qtde & $\%$ & Qtde & $\%$ & Qtde & $\%$ & Qtde & $\%$ & Qtde & $\%$ \\
\hline Extroversão & 276 & $42,9 \%$ & 46 & $7,1 \%$ & 157 & $24,4 \%$ & 165 & $25,6 \%$ & 644 & $100 \%$ \\
\hline Introversão & 37 & $43,0 \%$ & 6 & $7,0 \%$ & 26 & $30,2 \%$ & 17 & $19,8 \%$ & 86 & $100 \%$ \\
\hline Total & 313 & $42,9 \%$ & 52 & $7,1 \%$ & 183 & $25,1 \%$ & 182 & $24,9 \%$ & 730 & $100 \%$ \\
\hline
\end{tabular}

Quadro 176 - Tabela Cruzada: Extroversão / Introversão vs. Volume Médio Rotativo

Chi-Square Tests

\begin{tabular}{|l|r|r|r|}
\hline & Value & df & $\begin{array}{c}\text { Asymp. Sig. } \\
\text { (2-sided) }\end{array}$ \\
\hline Pearson Chi-Square & 2,083 & & 3 \\
N of Valid Cases & 730 & &, 555 \\
\hline
\end{tabular}

Quadro 177 - Teste Qui-quadrado: Extroversão / Introversão vs. Volume Médio Rotativo

Teste Qui-Quadrado: Não há evidências que permitam rejeitar a hipótese nula de não associação das variáveis, ou seja, as evidências indicam a independência das variáveis. 
Sensação / Intuição:

\begin{tabular}{|c|c|c|c|c|c|c|c|c|c|c|}
\hline & \multicolumn{8}{|c|}{ Volume Médio Rotativo (Banded) } & \multirow{2}{*}{\multicolumn{2}{|c|}{ Total }} \\
\hline & \multicolumn{2}{|c|}{$<=, 00$} & \multicolumn{2}{|c|}{$01-50,75$} & \multicolumn{2}{|c|}{$50,76-489,50$} & \multicolumn{2}{|c|}{$489,51+$} & & \\
\hline & Qtde & $\%$ & Qtde & $\%$ & Qtde & $\%$ & Qtde & $\%$ & Qtde & $\%$ \\
\hline Intuição & 138 & $44,2 \%$ & 24 & $7,7 \%$ & 75 & $24,0 \%$ & 75 & $24,0 \%$ & 312 & $100 \%$ \\
\hline Sensação & 175 & $41,9 \%$ & 28 & $6,7 \%$ & 108 & $25,8 \%$ & 107 & $25,6 \%$ & 418 & $100 \%$ \\
\hline Total & 313 & $42,9 \%$ & 52 & $7,1 \%$ & 183 & $25,1 \%$ & 182 & $24,9 \%$ & 730 & $100 \%$ \\
\hline
\end{tabular}

Quadro 178 - Tabela Cruzada: Sensação / Intuição vs. Volume Médio Rotativo

Chi-Square Tests

\begin{tabular}{|c|c|c|c|}
\hline & Value & $d f$ & $\begin{array}{l}\text { Asymp. Sig. } \\
\text { (2-sided) }\end{array}$ \\
\hline $\begin{array}{l}\text { Pearson Chi-Square } \\
\mathrm{N} \text { of Valid Cases }\end{array}$ & $\begin{array}{l}, 886 \\
730\end{array}$ & 3 & ,829 \\
\hline
\end{tabular}

Quadro 179 - Teste Qui-quadrado: Sensação / Intuição vs. Volume Médio Rotativo

Teste Qui-quadrado: Não há evidências que permitam rejeitar a hipótese nula de não associação das variáveis, ou seja, as evidências indicam a independência das variáveis. 
Sentimento / Pensamento:

\begin{tabular}{|c|c|c|c|c|c|c|c|c|c|c|}
\hline & \multicolumn{8}{|c|}{ Volume Médio Rotativo (Banded) } & & \\
\hline & \multicolumn{2}{|c|}{$<=, 00$} & \multicolumn{2}{|c|}{$, 01-50,75$} & \multicolumn{2}{|c|}{$50,76-489,50$} & \multicolumn{2}{|c|}{$489,51+$} & \multicolumn{2}{|c|}{ Total } \\
\hline & Qtde & $\%$ & Qtde & $\%$ & Qtde & $\%$ & Qtde & $\%$ & Qtde & $\%$ \\
\hline Sentimento & 139 & $43,4 \%$ & 24 & $7,5 \%$ & 79 & $24,7 \%$ & 78 & $24,4 \%$ & 320 & $100 \%$ \\
\hline Pensamento & 174 & $42,4 \%$ & 28 & $6,8 \%$ & 104 & $25,4 \%$ & 104 & $25,4 \%$ & 410 & $100 \%$ \\
\hline Total & 313 & $42,9 \%$ & 52 & $7,1 \%$ & 183 & $25,1 \%$ & 182 & $24,9 \%$ & 730 & $100 \%$ \\
\hline
\end{tabular}

Quadro 180 - Tabela Cruzada: Sensação/Intuição vs. Volume Médio Rotativo

Chi-Square Tests

\begin{tabular}{|c|c|c|c|}
\hline & Value & $d f$ & $\begin{array}{l}\text { Asymp. Sig. } \\
\text { (2-sided) }\end{array}$ \\
\hline $\begin{array}{l}\text { Pearson Chi-Square } \\
\mathrm{N} \text { of Valid Cases }\end{array}$ & $\begin{array}{l}, 259 \\
730\end{array}$ & 3 & ,968 \\
\hline
\end{tabular}

Quadro 181 - Teste Qui-quadrado: Sensação/Intuição vs. Volume Médio Rotativo

Teste Qui-quadrado: Não há evidências que permitam rejeitar a hipótese nula de não associação das variáveis, ou seja, as evidências indicam a independência das variáveis. 
Julgamento / Percepção:

\begin{tabular}{|c|c|c|c|c|c|c|c|c|c|c|}
\hline & \multicolumn{8}{|c|}{ Volume Médio Rotativo (Banded) } & & \\
\hline & \multicolumn{2}{|c|}{$<=, 00$} & \multicolumn{2}{|c|}{$01-50,75$} & \multicolumn{2}{|c|}{$50,76-489,50$} & \multicolumn{2}{|c|}{$489,51+$} & \multicolumn{2}{|c|}{ Total } \\
\hline & Qtde & $\%$ & Qtde & $\%$ & Qtde & $\%$ & Qtde & $\%$ & Qtde & $\%$ \\
\hline Julgamento & 277 & $43,3 \%$ & 47 & $7,3 \%$ & 158 & $24,7 \%$ & 158 & $24,7 \%$ & 640 & $100 \%$ \\
\hline Percepção & 36 & $40,0 \%$ & 5 & $5,6 \%$ & 25 & $27,8 \%$ & 24 & $26,7 \%$ & 90 & $100 \%$ \\
\hline Total & 313 & $42,9 \%$ & 52 & $7,1 \%$ & 183 & $25,1 \%$ & 182 & $24,9 \%$ & 730 & $100 \%$ \\
\hline
\end{tabular}

Quadro 182 - Tabela Cruzada: Julgamento / Percepção vs. Volume Médio Rotativo

Chi-Square Tests

\begin{tabular}{|c|c|c|c|}
\hline & Value & $\mathrm{df}$ & $\begin{array}{c}\text { Asymp. Sig. } \\
\text { (2-sided) }\end{array}$ \\
\hline Pearson Chi-Square & ,977 & 3 & 807 \\
\hline $\mathrm{N}$ of Valid Cases & 730 & & \\
\hline
\end{tabular}

Quadro 183 - Teste Qui-quadrado: Julgamento / Percepção vs. Volume Médio Rotativo

Teste Qui-quadrado: Não há evidências que permitam rejeitar a hipótese nula de não associação das variáveis, ou seja, as evidências indicam a independência das variáveis. 
Índice: Gastos com Compras / Renda

Os 4 Temperamentos vs. Índice Compras / Renda:

Análise Gráfica:

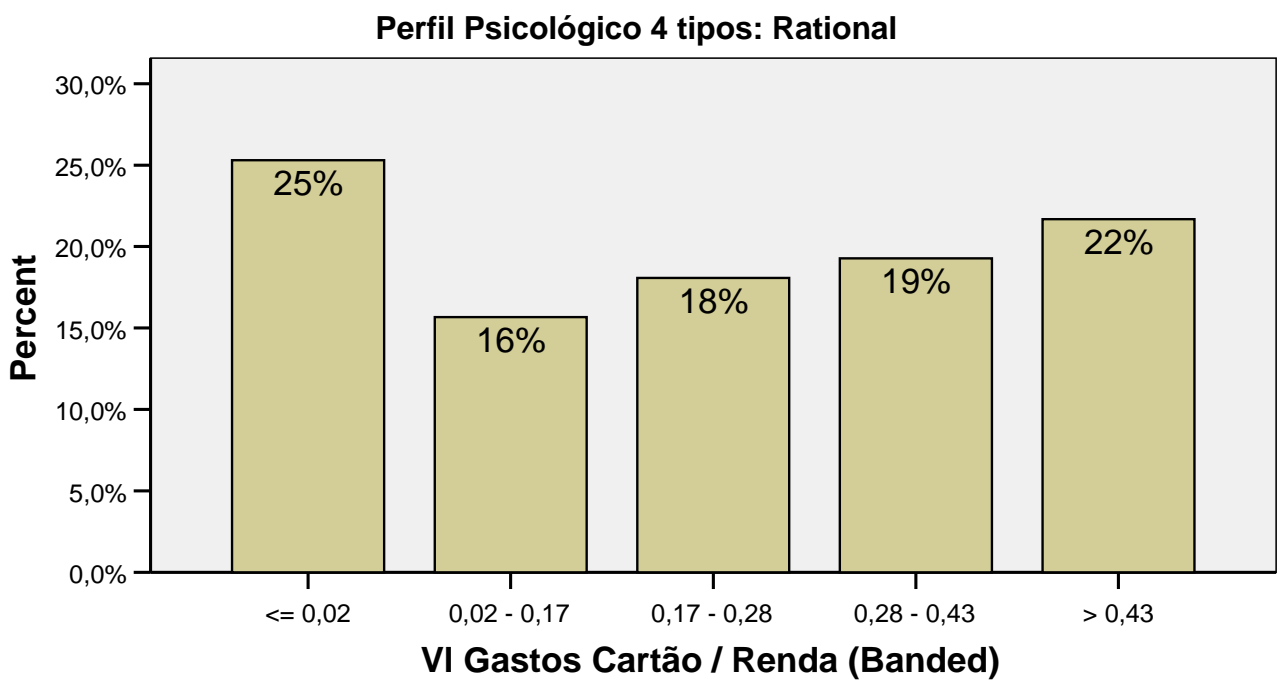

Gráfico 25 - Rational: Valor de Gastos com Cartão de Crédito / Renda

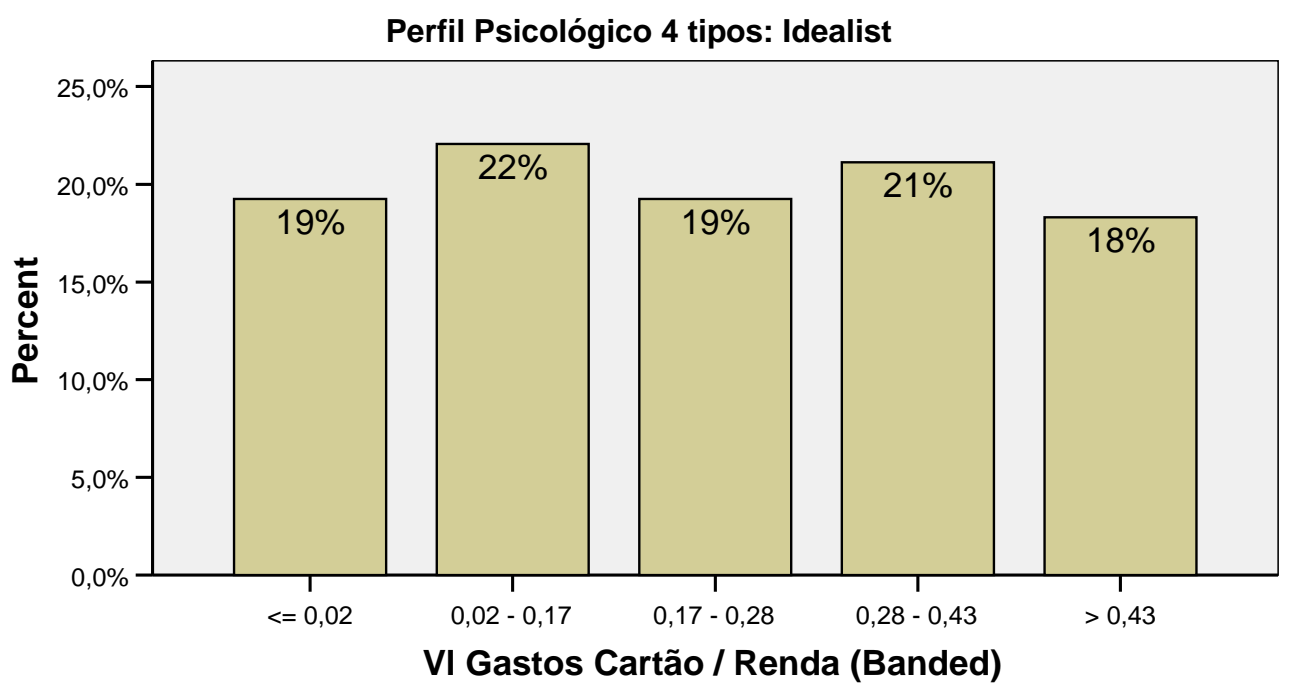

Gráfico 26 - Idealist: Valor de Gastos com Cartão de Crédito / Renda 


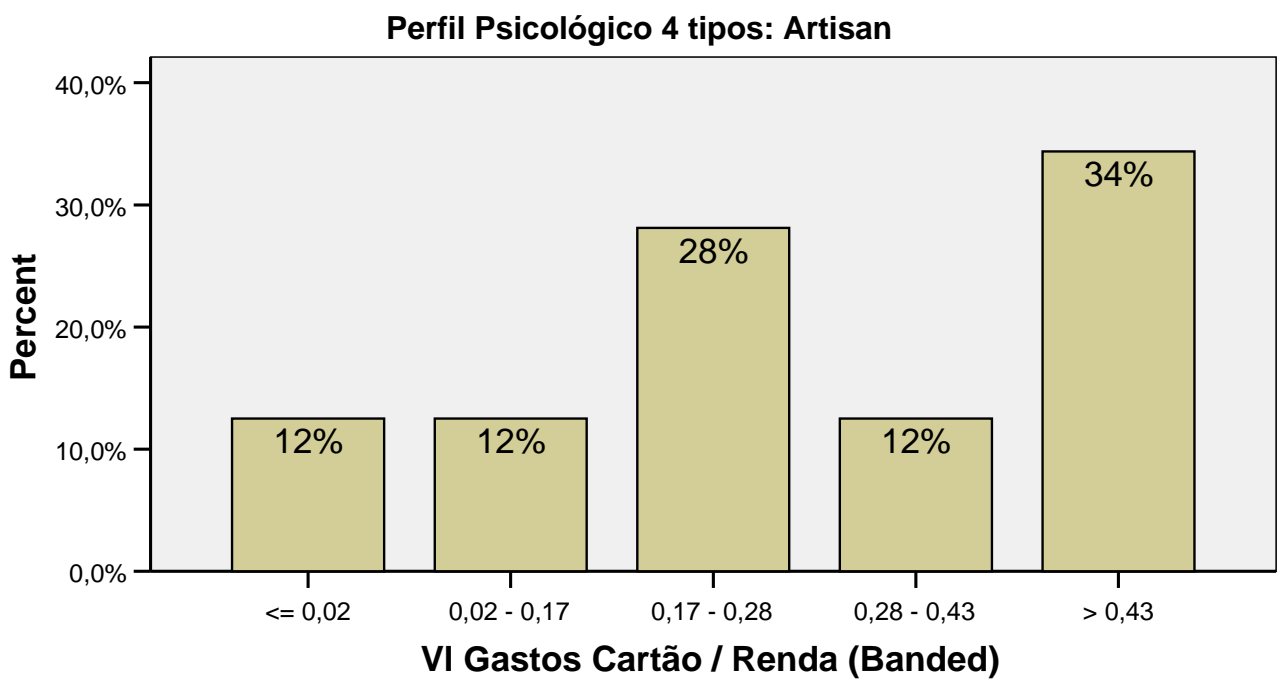

Gráfico 27 - Artisan: Valor de Gastos com Cartão de Crédito / Renda

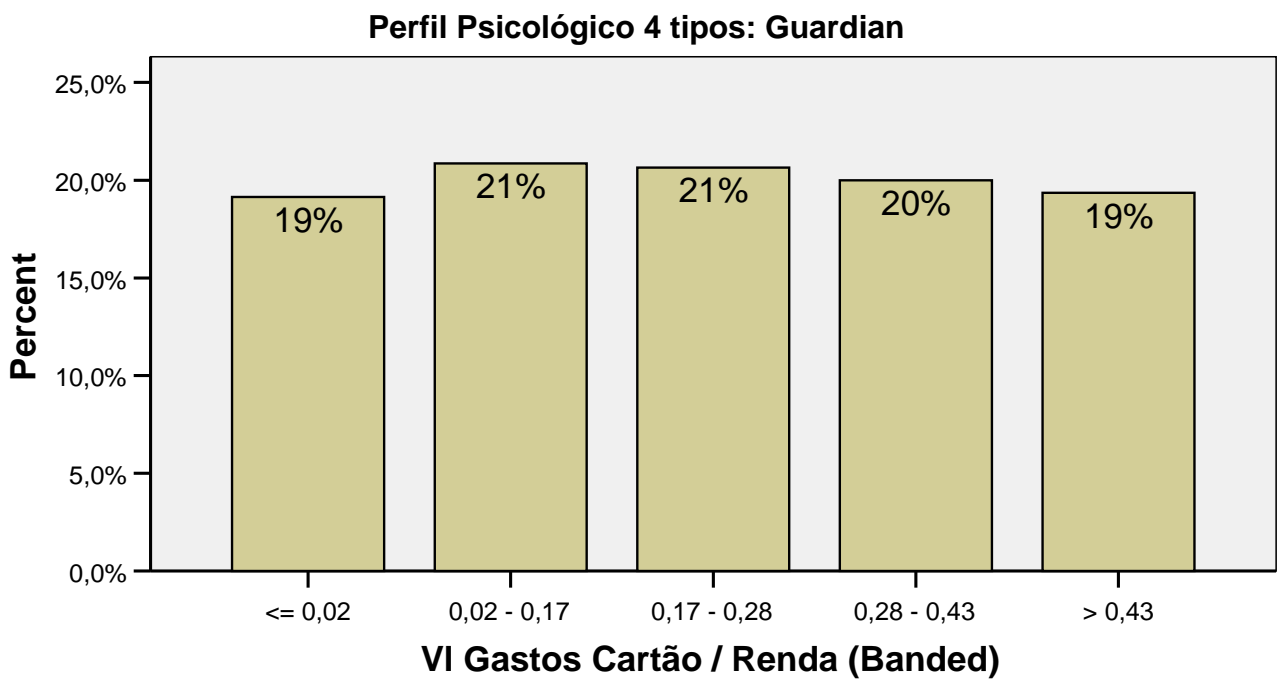

Gráfico 28 - Guardian: Valor de Gastos com Cartão de Crédito / Renda 
Tabelas:

\begin{tabular}{|c|c|c|c|c|c|c|c|c|c|c|c|c|}
\hline & \multicolumn{10}{|c|}{ VI Gastos Cartão / Renda (Banded) } & \multirow{2}{*}{\multicolumn{2}{|c|}{ Total }} \\
\hline & \multicolumn{2}{|c|}{$<=0,02$} & \multicolumn{2}{|c|}{$0,02-0,17$} & \multicolumn{2}{|c|}{$0,17-0,28$} & \multicolumn{2}{|c|}{$0,28-0,43$} & \multicolumn{2}{|c|}{$>0,43$} & & \\
\hline & Qtde & $\%$ & Qtde & $\%$ & Qtde & $\%$ & Qtde & $\%$ & Qtde & $\%$ & Qtde & $\%$ \\
\hline Rational & 42 & $25,3 \%$ & 26 & $15,7 \%$ & 30 & $18,1 \%$ & 32 & $19,3 \%$ & 36 & $21,7 \%$ & 166 & $100 \%$ \\
\hline Idealist & 41 & $19,2 \%$ & 47 & $22,1 \%$ & 41 & $19,2 \%$ & 45 & $21,1 \%$ & 39 & $18,3 \%$ & 213 & $100 \%$ \\
\hline Artisan & 4 & $12,5 \%$ & 4 & $12,5 \%$ & 9 & $28,1 \%$ & 4 & $12,5 \%$ & 11 & $34,4 \%$ & 32 & $100 \%$ \\
\hline Guardian & 89 & $19,1 \%$ & 97 & $20,9 \%$ & 96 & $20,6 \%$ & 93 & $20,0 \%$ & 90 & $19,4 \%$ & 465 & $100 \%$ \\
\hline Total & 176 & $20,1 \%$ & 174 & $19,9 \%$ & 176 & $20,1 \%$ & 174 & $19,9 \%$ & 176 & $20,1 \%$ & 876 & $100 \%$ \\
\hline
\end{tabular}

Quadro 184 - Faixas de Índice Gastos/Renda por Perfil Psicológico

\section{Chi-Square Tests}

\begin{tabular}{|l|r|r|r|}
\hline & Value & df & \multicolumn{1}{|c|}{$\begin{array}{c}\text { Asymp. Sig. } \\
\text { (2-sided) }\end{array}$} \\
\hline Pearson Chi-Square & 13,057 & 12 &, 365 \\
N of Valid Cases & 876 & & \\
\hline
\end{tabular}

Quadro 185 - Teste Qui-Quadrado: Gastos/Renda por Perfil Psicológico

Teste Qui-Quadrado: Não há evidências que permitam rejeitar a hipótese nula de não associação das variáveis, ou seja, as evidências indicam a independência das variáveis.

Também nesse índice pode-se observar um comportamento distinto, segundo a ótica gráfica dos Artisans, não confirmado estatisticamente, possivelmente em razão do reduzido número de representantes desse temperamento na amostra. 
As 16 Variações de Temperamento vs. Índice Compras / Renda

\begin{tabular}{|c|c|c|c|c|c|c|c|c|c|c|c|c|}
\hline & \multicolumn{10}{|c|}{ VI Gastos Cartão / Renda (Banded) } & \multirow{2}{*}{\multicolumn{2}{|c|}{ Total }} \\
\hline & \multicolumn{2}{|c|}{$<=0,02$} & \multicolumn{2}{|c|}{$0,02-0,17$} & \multicolumn{2}{|c|}{$0,17-0,28$} & \multicolumn{2}{|c|}{$0,28-0,43$} & \multicolumn{2}{|c|}{$>0,43$} & & \\
\hline & Qtde & $\%$ & Qtde & $\%$ & Qtde & $\%$ & Qtde & $\%$ & Qtde & $\%$ & Qtde & $\%$ \\
\hline ENFJ & 26 & $20,0 \%$ & 29 & $22,3 \%$ & 27 & $20,8 \%$ & 28 & $21,5 \%$ & 20 & $15,4 \%$ & 130 & $100 \%$ \\
\hline ENFP & 10 & $16,7 \%$ & 13 & $21,7 \%$ & 10 & $16,7 \%$ & 12 & $20,0 \%$ & 15 & $25,0 \%$ & 60 & $100 \%$ \\
\hline ENTJ & 30 & $22,4 \%$ & 23 & $17,2 \%$ & 26 & $19,4 \%$ & 26 & $19,4 \%$ & 29 & $21,6 \%$ & 134 & $100 \%$ \\
\hline ENTP & 6 & $37,5 \%$ & 1 & $6,3 \%$ & 2 & $12,5 \%$ & 2 & $12,5 \%$ & 5 & $31,3 \%$ & 16 & $100 \%$ \\
\hline ESFJ & 23 & $17,8 \%$ & 33 & $25,6 \%$ & 24 & $18,6 \%$ & 28 & $21,7 \%$ & 21 & $16,3 \%$ & 129 & $100 \%$ \\
\hline ESFP & 1 & $6,3 \%$ & 2 & $12,5 \%$ & 5 & $31,3 \%$ & 2 & $12,5 \%$ & 6 & $37,5 \%$ & 16 & $100 \%$ \\
\hline ESTJ & 48 & $18,1 \%$ & 50 & $18,9 \%$ & 56 & $21,1 \%$ & 53 & $20,0 \%$ & 58 & $21,9 \%$ & 265 & $100 \%$ \\
\hline ESTP & 2 & $16,7 \%$ & 1 & $8,3 \%$ & 4 & $33,3 \%$ & 1 & $8,3 \%$ & 4 & $33,3 \%$ & 12 & $100 \%$ \\
\hline INFJ & 2 & $10,0 \%$ & 5 & $25,0 \%$ & 4 & $20,0 \%$ & 5 & $25,0 \%$ & 4 & $20,0 \%$ & 20 & $100 \%$ \\
\hline INFP & 3 & $100 \%$ & 0 &, $0 \%$ & 0 &, $0 \%$ & 0 &, $0 \%$ & 0 &, $0 \%$ & 3 & $100 \%$ \\
\hline INTJ & 5 & $35,7 \%$ & 2 & $14,3 \%$ & 2 & $14,3 \%$ & 3 & $21,4 \%$ & 2 & $14,3 \%$ & 14 & $100 \%$ \\
\hline INTP & 1 & $50,0 \%$ & 0 &, $0 \%$ & 0 &, $0 \%$ & 1 & $50,0 \%$ & 0 &, $0 \%$ & 2 & $100 \%$ \\
\hline ISFJ & 6 & $26,1 \%$ & 3 & $13,0 \%$ & 4 & $17,4 \%$ & 4 & $17,4 \%$ & 6 & $26,1 \%$ & 23 & $100 \%$ \\
\hline ISFP & 1 & $33,3 \%$ & 1 & $33,3 \%$ & 0 &, $0 \%$ & 1 & $33,3 \%$ & 0 &, $0 \%$ & 3 & $100 \%$ \\
\hline ISTJ & 12 & $25,0 \%$ & 11 & $22,9 \%$ & 12 & $25,0 \%$ & 8 & $16,7 \%$ & 5 & $10,4 \%$ & 48 & $100 \%$ \\
\hline ISTP & 0 &, $0 \%$ & 0 &, $0 \%$ & 0 &, $0 \%$ & 0 &, $0 \%$ & 1 & $100 \%$ & 1 & $100 \%$ \\
\hline Total & 176 & $20,1 \%$ & 174 & $19,9 \%$ & 176 & $20,1 \%$ & 174 & $19,9 \%$ & 176 & $20,1 \%$ & 876 & $100 \%$ \\
\hline
\end{tabular}

Quadro 186 - Tabela Cruzada: 16 tipos vs. Índice Compras / Renda

Chi-Square Tests

\begin{tabular}{|l|r|r|r|}
\hline & \multicolumn{1}{|c|}{ Value } & df & \multicolumn{1}{c|}{$\begin{array}{c}\text { Asymp. Sig. } \\
(2-\text { sided })\end{array}$} \\
\hline Pearson Chi-Square & 55,200 & 60 &, 651 \\
N of Valid Cases & 876 & & \\
\hline
\end{tabular}

Quadro 187 - Teste Qui-quadrado: 16 tipos vs. Índice Compras / Renda

Teste Qui-quadrado: Não há evidências que permitam rejeitar a hipótese nula de não associação das variáveis, ou seja, as evidências indicam a independência das variáveis. 
As Dimensões de Temperamentos vs. Índice Compras / Renda:

Extroversão / Introversão:

\begin{tabular}{|c|c|c|c|c|c|c|c|c|c|c|c|c|}
\hline & \multicolumn{10}{|c|}{ VI Gastos Cartão / Renda (Banded) } & \multirow{2}{*}{\multicolumn{2}{|c|}{ Total }} \\
\hline & \multicolumn{2}{|c|}{$<=0,02$} & \multicolumn{2}{|c|}{$0,02-0,17$} & \multicolumn{2}{|c|}{$0,17-0,28$} & \multicolumn{2}{|c|}{$0,28-0,43$} & \multicolumn{2}{|c|}{$>0,43$} & & \\
\hline & Qtde & $\%$ & Qtde & $\%$ & Qtde & $\%$ & Qtde & $\%$ & Qtde & $\%$ & Qtde & $\%$ \\
\hline Extroversão & 146 & $19,2 \%$ & 152 & $19,9 \%$ & 154 & $20,2 \%$ & 152 & $19,9 \%$ & 158 & $20,7 \%$ & 762 & $100 \%$ \\
\hline Introversão & 30 & $26,3 \%$ & 22 & $19,3 \%$ & 22 & $19,3 \%$ & 22 & $19,3 \%$ & 18 & $15,8 \%$ & 114 & $100 \%$ \\
\hline Total & 176 & $20,1 \%$ & 174 & $19,9 \%$ & 176 & $20,1 \%$ & 174 & $19,9 \%$ & 176 & $20,1 \%$ & 876 & $100 \%$ \\
\hline
\end{tabular}

Quadro 188 - Tabela Cruzada: Extroversão / Introversão vs. Índice Compras / Renda

Chi-Square Tests

\begin{tabular}{|c|c|c|c|}
\hline & Value & $\mathrm{df}$ & $\begin{array}{l}\text { Asymp. Sig. } \\
\text { (2-sided) }\end{array}$ \\
\hline Pearson Chi-Square & 2,300 & 3 &, 512 \\
\hline $\mathrm{N}$ of Valid Cases & 876 & & \\
\hline
\end{tabular}

Quadro 189 - Teste Qui-Quadrado: Extroversão / Introversão vs. Índice Compras / Renda

Teste Qui-quadrado: Não há evidências que permitam rejeitar a hipótese nula de não associação das variáveis, ou seja, as evidências indicam a independência das variáveis. 
Sensação / Intuição:

\begin{tabular}{|c|c|c|c|c|c|c|c|c|c|c|c|c|}
\hline & \multicolumn{10}{|c|}{ VI Gastos Cartão / Renda (Banded) } & \multirow{2}{*}{\multicolumn{2}{|c|}{ Total }} \\
\hline & \multicolumn{2}{|c|}{$<=0,02$} & \multicolumn{2}{|c|}{$0,02-0,17$} & \multicolumn{2}{|c|}{$0,17-0,28$} & \multicolumn{2}{|c|}{$0,28-0,43$} & \multicolumn{2}{|c|}{$>0,43$} & & \\
\hline & Qtde & $\%$ & Qtde & $\%$ & Qtde & $\%$ & Qtde & $\%$ & Qtde & $\%$ & Qtde & $\%$ \\
\hline Intuição & 83 & $21,9 \%$ & 73 & $19,3 \%$ & 71 & $18,7 \%$ & 77 & $20,3 \%$ & 75 & $19,8 \%$ & 379 & $100 \%$ \\
\hline Sensação & 93 & $18,7 \%$ & 101 & $20,3 \%$ & 105 & $21,1 \%$ & 97 & $19,5 \%$ & 101 & $20,3 \%$ & 497 & $100 \%$ \\
\hline Total & 176 & $20,1 \%$ & 174 & $19,9 \%$ & 176 & $20,1 \%$ & 174 & $19,9 \%$ & 176 & $20,1 \%$ & 876 & $100 \%$ \\
\hline
\end{tabular}

Quadro 190 - Tabela Cruzada: Intuição / Sensação vs. Índice Compras / Renda

Chi-Square Tests

\begin{tabular}{|c|c|c|c|}
\hline & Value & $\mathrm{df}$ & $\begin{array}{l}\text { Asymp. Sig. } \\
\text { (2-sided) }\end{array}$ \\
\hline $\begin{array}{l}\text { Pearson Chi-Square } \\
\mathrm{N} \text { of Valid Cases }\end{array}$ & $\begin{array}{r}1,922 \\
876\end{array}$ & 4 & ,750 \\
\hline
\end{tabular}

Quadro 191 - Teste Qui-Quadrado: Intuição / Sensação vs. Índice Compras / Renda

Teste Qui-Quadrado: Não há evidências que permitam rejeitar a hipótese nula de não associação das variáveis, ou seja, as evidências indicam a independência das variáveis. 
Sentimento / Pensamento:

\begin{tabular}{|c|c|c|c|c|c|c|c|c|c|c|c|c|}
\hline & \multicolumn{10}{|c|}{ VI Gastos Cartão / Renda (Banded) } & \multirow{2}{*}{\multicolumn{2}{|c|}{ Total }} \\
\hline & \multicolumn{2}{|c|}{$<=0,02$} & \multicolumn{2}{|c|}{$0,02-0,17$} & \multicolumn{2}{|c|}{$0,17-0,28$} & \multicolumn{2}{|c|}{$0,28-0,43$} & \multicolumn{2}{|c|}{$>0,43$} & & \\
\hline & Qtde & $\%$ & Qtde & $\%$ & Qtde & $\%$ & Qtde & $\%$ & Qtde & $\%$ & Qtde & $\%$ \\
\hline Sentimento & 72 & $18,8 \%$ & 86 & $22,4 \%$ & 74 & $19,3 \%$ & 80 & $20,8 \%$ & 72 & $18,8 \%$ & 384 & $100 \%$ \\
\hline Pensamento & 104 & $21,1 \%$ & 88 & $17,9 \%$ & 102 & $20,7 \%$ & 94 & $19,1 \%$ & 104 & $21,1 \%$ & 492 & $100 \%$ \\
\hline Total & 176 & $20,1 \%$ & 174 & $19,9 \%$ & 176 & $20,1 \%$ & 174 & $19,9 \%$ & 176 & $20,1 \%$ & 876 & $100 \%$ \\
\hline
\end{tabular}

Quadro 192 - Tabela Cruzada: Sentimento / Pensamento vs. Índice Compras / Renda

Chi-Square Tests

\begin{tabular}{|c|c|c|c|}
\hline & Value & df & $\begin{array}{l}\text { Asymp. Sig. } \\
\text { (2-sided) }\end{array}$ \\
\hline $\begin{array}{l}\text { Pearson Chi-Square } \\
\mathrm{N} \text { of Valid Cases }\end{array}$ & $\begin{array}{r}3,986 \\
876\end{array}$ & 4 & ,408 \\
\hline
\end{tabular}

Quadro 193 - Teste Qui-Quadrado: Sentimento / Pensamento vs. Índice Compras / Renda

Teste Qui-Quadrado: Não há evidências que permitam rejeitar a hipótese nula de não associação das variáveis, ou seja, as evidências indicam a independência das variáveis. 
Julgamento / Percepção:

\begin{tabular}{|c|c|c|c|c|c|c|c|c|c|c|c|c|}
\hline & \multicolumn{10}{|c|}{ VI Gastos Cartão / Renda (Banded) } & \multirow{2}{*}{\multicolumn{2}{|c|}{ Total }} \\
\hline & \multicolumn{2}{|c|}{$<=0,02$} & \multicolumn{2}{|c|}{$0,02-0,17$} & \multicolumn{2}{|c|}{$0,17-0,28$} & \multicolumn{2}{|c|}{$0,28-0,43$} & \multicolumn{2}{|c|}{$>0,43$} & & \\
\hline & Qtde & $\%$ & Qtde & $\%$ & Qtde & $\%$ & Qtde & $\%$ & Qtde & $\%$ & Qtde & $\%$ \\
\hline Julgamento & 152 & $19,9 \%$ & 156 & $20,4 \%$ & 155 & $20,3 \%$ & 155 & $20,3 \%$ & 145 & $19,0 \%$ & 763 & $100 \%$ \\
\hline Percepção & 24 & $21,2 \%$ & 18 & $15,9 \%$ & 21 & $18,6 \%$ & 19 & $16,8 \%$ & 31 & $27,4 \%$ & 113 & $100 \%$ \\
\hline Total & 176 & $20,1 \%$ & 174 & $19,9 \%$ & 176 & $20,1 \%$ & 174 & $19,9 \%$ & 176 & $20,1 \%$ & 876 & $100 \%$ \\
\hline
\end{tabular}

Quadro 194 - Tabela Cruzada: Sentimento / Pensamento vs. Índice Compras / Renda

\section{Chi-Square Tests}

\begin{tabular}{|c|c|c|c|}
\hline & Value & $\mathrm{df}$ & $\begin{array}{c}\text { Asymp. Sig. } \\
\text { (2-sided) }\end{array}$ \\
\hline $\begin{array}{l}\text { Pearson Chi-Square } \\
\mathrm{N} \text { of Valid Cases }\end{array}$ & $\begin{array}{r}5,331 \\
876\end{array}$ & 4 & ,255 \\
\hline
\end{tabular}

Quadro 195 - Teste Qui-Quadrado: Sentimento / Pensamento vs. Índice Compras / Renda

Teste Qui-Quadrado: Não há evidências que permitam rejeitar a hipótese nula de não associação das variáveis, ou seja, as evidências indicam a independência das variáveis. 
Índice: Crédito Rotativo / Renda

Os 4 Temperamentos vs. Rotativo / Renda

Análise Gráfica:

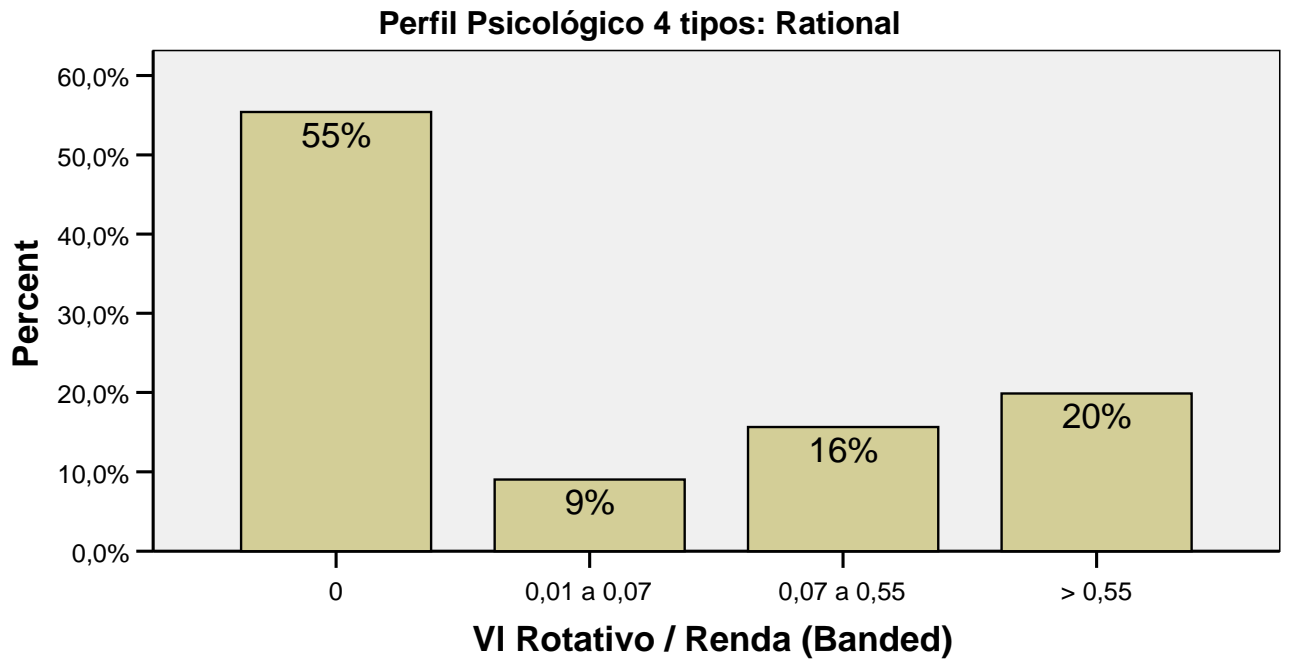

Gráfico 29 - Rational: Rotativo / Renda

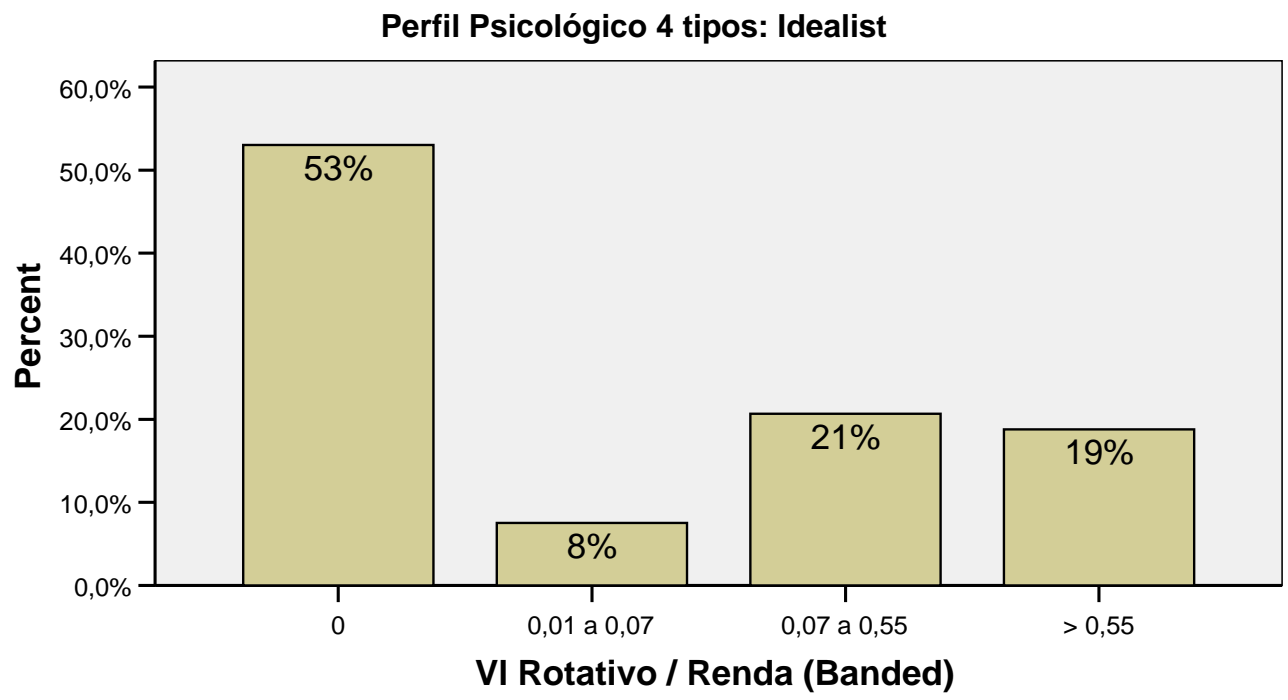

Gráfico 30 - Idealist: Rotativo / Renda 


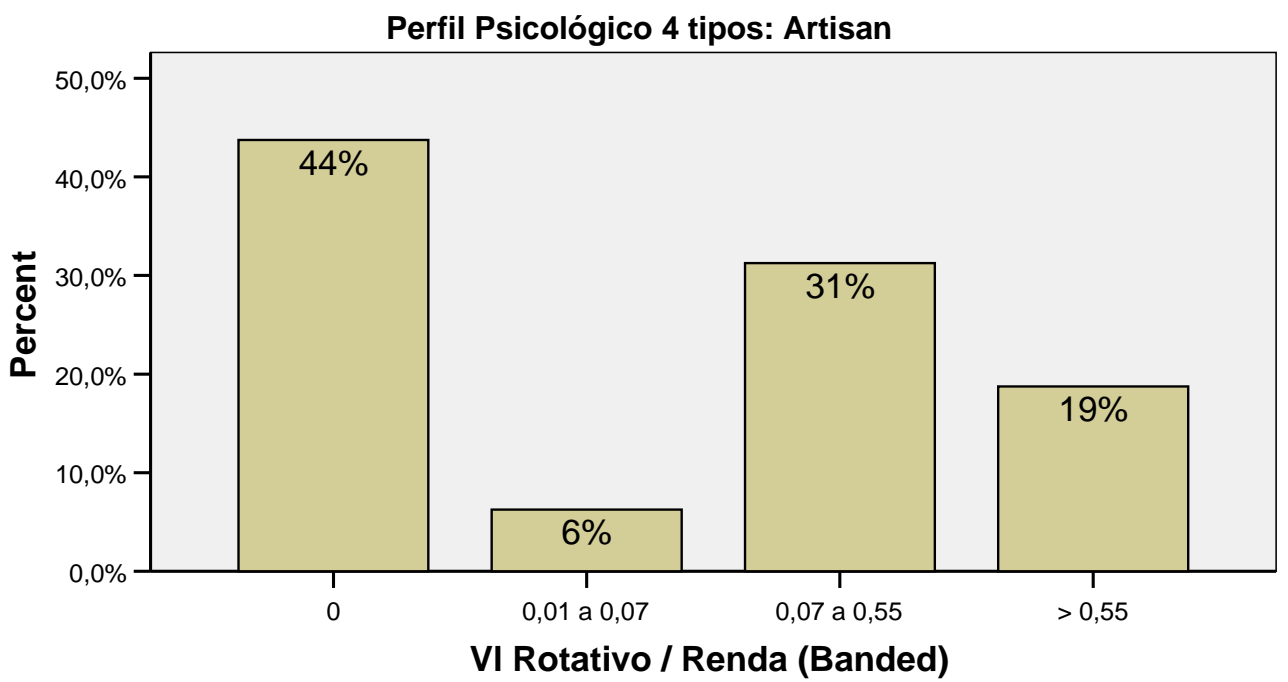

Gráfico 31 - Artisan: Idealist: Rotativo / Renda

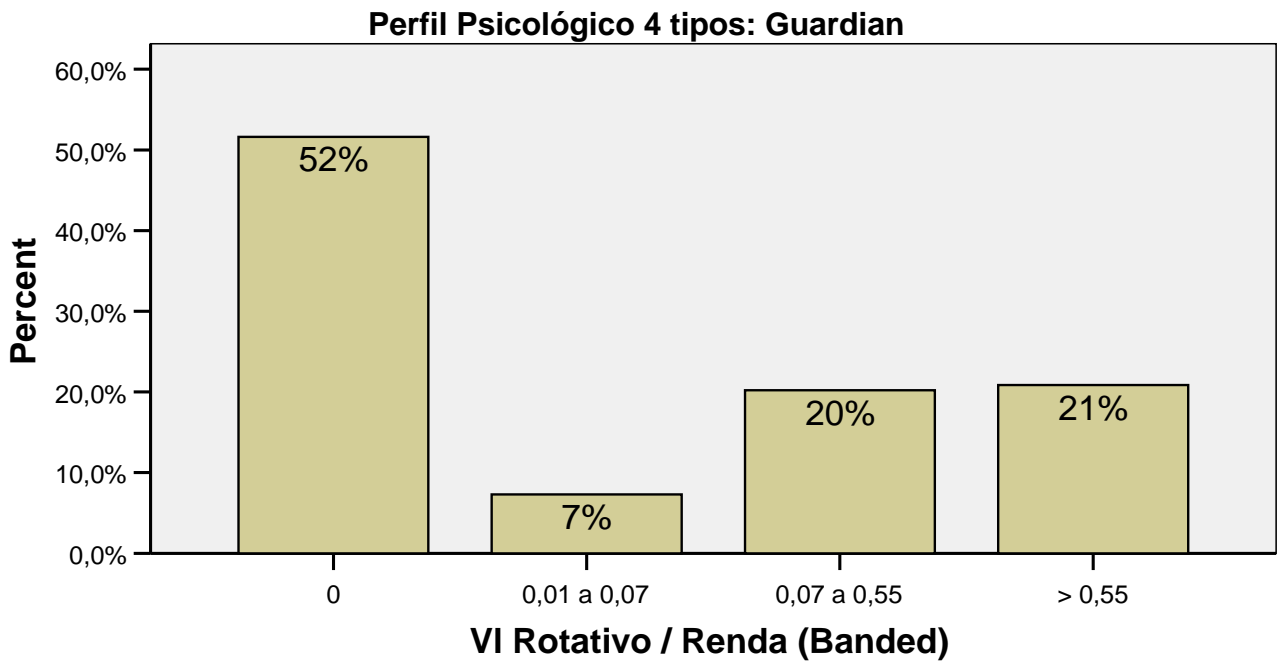

Gráfico 32 - Guardian: Rotativo / Renda 
Tabelas:

\begin{tabular}{|c|c|c|c|c|c|c|c|c|c|c|}
\hline & \multicolumn{8}{|c|}{ VI Rotativo / Renda (Banded) } & \multirow{2}{*}{\multicolumn{2}{|c|}{ Total }} \\
\hline & \multicolumn{2}{|c|}{0} & \multicolumn{2}{|c|}{0,01 a 0,07} & \multicolumn{2}{|c|}{0,07 a 0,55} & \multicolumn{2}{|c|}{$>0,55$} & & \\
\hline & Qtde & $\%$ & Qtde & $\%$ & Qtde & $\%$ & Qtde & $\%$ & Qtde & $\%$ \\
\hline Rational & 92 & $55,4 \%$ & 15 & $9,0 \%$ & 26 & $15,7 \%$ & 33 & $19,9 \%$ & 166 & $100 \%$ \\
\hline Idealist & 113 & $53,1 \%$ & 16 & $7,5 \%$ & 44 & $20,7 \%$ & 40 & $18,8 \%$ & 213 & $100 \%$ \\
\hline Artisan & 14 & $43,8 \%$ & 2 & $6,3 \%$ & 10 & $31,3 \%$ & 6 & $18,8 \%$ & 32 & $100 \%$ \\
\hline Guardian & 240 & $51,6 \%$ & 34 & $7,3 \%$ & 94 & $20,2 \%$ & 97 & $20,9 \%$ & 465 & $100 \%$ \\
\hline Total & 459 & $52,4 \%$ & 67 & $7,6 \%$ & 174 & $19,9 \%$ & 176 & $20,1 \%$ & 876 & $100 \%$ \\
\hline
\end{tabular}

Quadro 196 - Faixas de Rotativo/Renda por Perfil Psicológico

Chi-Square Tests

\begin{tabular}{|c|c|c|c|}
\hline & Value & df & $\begin{array}{l}\text { Asymp. Sig. } \\
\text { (2-sided) }\end{array}$ \\
\hline $\begin{array}{l}\text { Pearson Chi-Square } \\
\mathrm{N} \text { of Valid Cases }\end{array}$ & $\begin{array}{r}5,404 \\
876\end{array}$ & 9 & ,798 \\
\hline
\end{tabular}

Quadro 197 - Teste Qui-Quadrado: Faixas Rotativo /Renda por Perfil Psicológico

Teste Qui-Quadrado: Não há evidências que permitam rejeitar a hipótese nula de não associação das variáveis, ou seja, as evidências indicam a independência das variáveis.

Conforme comentado anteriormente, os Artisans apresentaram uma configuração gráfica diferente dos demais temperamentos. A pequena quantidade de representantes desse grupo pode ter motivado a não evidência estatística dessa diferenciação. 
As 16 Variações de Temperamento vs. Índice Rotativo / Renda:

\begin{tabular}{|c|c|c|c|c|c|c|c|c|c|c|}
\hline & \multicolumn{8}{|c|}{ VI Rotativo / Renda (Banded) } & \multirow{2}{*}{\multicolumn{2}{|c|}{ Total }} \\
\hline & \multicolumn{2}{|c|}{0} & \multicolumn{2}{|c|}{0,01 a 0,07} & \multicolumn{2}{|c|}{0,07 a 0,55} & \multicolumn{2}{|c|}{$>0,55$} & & \\
\hline & Qtde & $\%$ & Qtde & $\%$ & Qtde & $\%$ & Qtde & $\%$ & Qtde & $\%$ \\
\hline ENFJ & 69 & $53,1 \%$ & 9 & $6,9 \%$ & 25 & $19,2 \%$ & 27 & $20,8 \%$ & 130 & $100 \%$ \\
\hline ENFP & 33 & $55,0 \%$ & 3 & $5,0 \%$ & 12 & $20,0 \%$ & 12 & $20,0 \%$ & 60 & $100 \%$ \\
\hline ENTJ & 73 & $54,5 \%$ & 13 & $9,7 \%$ & 23 & $17,2 \%$ & 25 & $18,7 \%$ & 134 & $100 \%$ \\
\hline ENTP & 7 & $43,8 \%$ & 2 & $12,5 \%$ & 3 & $18,8 \%$ & 4 & $25,0 \%$ & 16 & $100 \%$ \\
\hline ESFJ & 69 & $53,5 \%$ & 11 & $8,5 \%$ & 22 & $17,1 \%$ & 27 & $20,9 \%$ & 129 & $100 \%$ \\
\hline ESFP & 7 & $43,8 \%$ & 2 & $12,5 \%$ & 3 & $18,8 \%$ & 4 & $25,0 \%$ & 16 & $100 \%$ \\
\hline ESTJ & 131 & $49,4 \%$ & 18 & $6,8 \%$ & 58 & $21,9 \%$ & 58 & $21,9 \%$ & 265 & $100 \%$ \\
\hline ESTP & 5 & $41,7 \%$ & 0 &, $0 \%$ & 5 & $41,7 \%$ & 2 & $16,7 \%$ & 12 & $100 \%$ \\
\hline INFJ & 8 & $40,0 \%$ & 4 & $20,0 \%$ & 7 & $35,0 \%$ & 1 & $5,0 \%$ & 20 & $100 \%$ \\
\hline INFP & 3 & $100 \%$ & 0 &, $0 \%$ & 0 &, $0 \%$ & 0 &, $0 \%$ & 3 & $100 \%$ \\
\hline INTJ & 10 & $71,4 \%$ & 0 &, $0 \%$ & 0 &, $0 \%$ & 4 & $28,6 \%$ & 14 & $100 \%$ \\
\hline INTP & 2 & $100 \%$ & 0 &, $0 \%$ & 0 &, $0 \%$ & 0 &, $0 \%$ & 2 & $100 \%$ \\
\hline ISFJ & 12 & $52,2 \%$ & 1 & $4,3 \%$ & 5 & $21,7 \%$ & 5 & $21,7 \%$ & 23 & $100 \%$ \\
\hline ISFP & 2 & $66,7 \%$ & 0 &, $0 \%$ & 1 & $33,3 \%$ & 0 &, $0 \%$ & 3 & $100 \%$ \\
\hline ISTJ & 28 & $58,3 \%$ & 4 & $8,3 \%$ & 9 & $18,8 \%$ & 7 & $14,6 \%$ & 48 & $100 \%$ \\
\hline ISTP & 0 &, $0 \%$ & 0 &, $0 \%$ & 1 & $100 \%$ & 0 &, $0 \%$ & 1 & $100 \%$ \\
\hline Total & 459 & $52,4 \%$ & 67 & $7,6 \%$ & 174 & $19,9 \%$ & 176 & $20,1 \%$ & 876 & $100 \%$ \\
\hline
\end{tabular}

Quadro 198 - Tabela Cruzada: 16 tipos vs. Rotativo / Renda

Chi-Square Tests

\begin{tabular}{|l|r|r|r|}
\hline & Value & df & \multicolumn{1}{|c|}{$\begin{array}{c}\text { Asymp. Sig. } \\
\text { (2-sided) }\end{array}$} \\
\hline Pearson Chi-Square & 36,396 & 45 &, 816 \\
N of Valid Cases & 876 & & \\
\hline
\end{tabular}

Quadro 199 - Teste Qui-quadrado: 16 tipos vs. Rotativo / Renda

Teste Qui-Quadrado: Não há evidências que permitam rejeitar a hipótese nula de não associação das variáveis, ou seja, as evidências indicam a independência das variáveis. 
As Dimensões de Temperamentos vs. Índice Rotativo / Renda:

\section{Extroversão / Introversão}

\begin{tabular}{|c|c|c|c|c|c|c|c|c|c|c|}
\hline & \multicolumn{8}{|c|}{ VI Rotativo / Renda (Banded) } & \multirow{2}{*}{\multicolumn{2}{|c|}{ Total }} \\
\hline & \multicolumn{2}{|c|}{0} & \multicolumn{2}{|c|}{0,01 a 0,07} & \multicolumn{2}{|c|}{0,07 a 0,55} & \multicolumn{2}{|c|}{$>0,55$} & & \\
\hline & Qtde & $\%$ & Qtde & $\%$ & Qtde & $\%$ & Qtde & $\%$ & Qtde & $\%$ \\
\hline Extroversão & 394 & $51,7 \%$ & 58 & $7,6 \%$ & 151 & $19,8 \%$ & 159 & $20,9 \%$ & 762 & $100 \%$ \\
\hline Introversão & 65 & $57,0 \%$ & 9 & $7,9 \%$ & 23 & $20,2 \%$ & 17 & $14,9 \%$ & 114 & $100 \%$ \\
\hline Total & 459 & $52,4 \%$ & 67 & $7,6 \%$ & 174 & $19,9 \%$ & 176 & $20,1 \%$ & 876 & $100 \%$ \\
\hline
\end{tabular}

Quadro 200 - Tabela Cruzada: Extroversão / Introversão vs. Rotativo / Renda

Chi-Square Tests

\begin{tabular}{|c|c|c|c|}
\hline & Value & $\mathrm{df}$ & $\begin{array}{l}\text { Asymp. Sig. } \\
\text { (2-sided) }\end{array}$ \\
\hline $\begin{array}{l}\text { Pearson Chi-Square } \\
\mathrm{N} \text { of Valid Cases }\end{array}$ & $\begin{array}{r}2,300 \\
876\end{array}$ & 3 &, 512 \\
\hline
\end{tabular}

Quadro 201 - Teste Qui-quadrado: Extroversão / Introversão vs. Rotativo / Renda

Teste Qui-quadrado: Não há evidências que permitam rejeitar a hipótese nula de não associação das variáveis, ou seja, as evidências indicam a independência das variáveis. 
Sensação / Intuição

\begin{tabular}{|c|c|c|c|c|c|c|c|c|c|c|}
\hline & \multicolumn{8}{|c|}{ VI Rotativo / Renda (Banded) } & \multicolumn{2}{c|}{} \\
\cline { 2 - 11 } & \multicolumn{2}{|c|}{0} & \multicolumn{2}{|c|}{0,01 a 0,07} & 0,07 & 0,55 & \multicolumn{2}{c|}{$>0,55$} & \multicolumn{2}{c|}{ Total } \\
\cline { 2 - 11 } & Qtde & $\%$ & Qtde & $\%$ & Qtde & $\%$ & Qtde & $\%$ & Qtde & $\%$ \\
\hline Intuição & 205 & $54,1 \%$ & 31 & $8,2 \%$ & 70 & $18,5 \%$ & 73 & $19,3 \%$ & 379 & $100 \%$ \\
Sensação & 254 & $51,1 \%$ & 36 & $7,2 \%$ & 104 & $20,9 \%$ & 103 & $20,7 \%$ & 497 & $100 \%$ \\
Total & 459 & $52,4 \%$ & 67 & $7,6 \%$ & 174 & $19,9 \%$ & 176 & $20,1 \%$ & 876 & $100 \%$ \\
\hline
\end{tabular}

Quadro 202 - Tabela Cruzada: Sensação / Intuição vs. Rotativo / Renda

Chi-Square Tests

\begin{tabular}{|c|c|c|c|}
\hline & Value & df & $\begin{array}{c}\text { Asymp. Sig. } \\
\text { (2-sided) }\end{array}$ \\
\hline Pearson Chi-Square & 1,494 & 3 & ,684 \\
\hline $\mathrm{N}$ of Valid Cases & 876 & & \\
\hline
\end{tabular}

Quadro 203 - Teste Qui-quadrado: Sensação / Intuição vs. Rotativo / Renda

Teste Qui-quadrado: Não há evidências que permitam rejeitar a hipótese nula de não associação das variáveis, ou seja, as evidências indicam a independência das variáveis. 
Sentimento / Pensamento

\begin{tabular}{|c|c|c|c|c|c|c|c|c|c|c|}
\hline & \multicolumn{8}{|c|}{ VI Rotativo / Renda (Banded) } & \multirow{2}{*}{\multicolumn{2}{|c|}{ Total }} \\
\hline & \multicolumn{2}{|c|}{0} & \multicolumn{2}{|c|}{0,01 a 0,07} & \multicolumn{2}{|c|}{0,07 a 0,55} & \multicolumn{2}{|c|}{$>0,55$} & & \\
\hline & Qtde & $\%$ & Qtde & $\%$ & Qtde & $\%$ & Qtde & $\%$ & Qtde & $\%$ \\
\hline Sentimento & 203 & $52,9 \%$ & 30 & $7,8 \%$ & 75 & $19,5 \%$ & 76 & $19,8 \%$ & 384 & $100 \%$ \\
\hline Pensamento & 256 & $52,0 \%$ & 37 & $7,5 \%$ & 99 & $20,1 \%$ & 100 & $20,3 \%$ & 492 & $100 \%$ \\
\hline Total & 459 & $52,4 \%$ & 67 & $7,6 \%$ & 174 & $19,9 \%$ & 176 & $20,1 \%$ & 876 & $100 \%$ \\
\hline
\end{tabular}

Quadro 204 - Tabela Cruzada: Sentimento / Pensamento vs. Rotativo/ Renda

Chi-Square Tests

\begin{tabular}{|c|c|c|c|}
\hline & Value & df & $\begin{array}{l}\text { Asymp. Sig. } \\
\text { (2-sided) }\end{array}$ \\
\hline Pearson Chi-Square & ,121 & 3 & ,989 \\
\hline $\mathrm{N}$ of Valid Cases & 876 & & \\
\hline
\end{tabular}

Quadro 205 - Teste Qui-quadrado: Sentimento / Pensamento vs. Rotativo/ Renda

Teste Qui-quadrado: Não há evidências que permitam rejeitar a hipótese nula de não associação das variáveis, ou seja, as evidências indicam a independência das variáveis. 
Julgamento / Percepção

\begin{tabular}{|c|c|c|c|c|c|c|c|c|c|c|}
\hline & \multicolumn{8}{|c|}{ VI Rotativo / Renda (Banded) } & \multirow{2}{*}{\multicolumn{2}{|c|}{ Total }} \\
\hline & \multicolumn{2}{|c|}{0} & \multicolumn{2}{|c|}{0,01 a 0,07} & \multicolumn{2}{|c|}{0,07 a 0,55} & \multicolumn{2}{|c|}{$>0,55$} & & \\
\hline & Qtde & $\%$ & Qtde & $\%$ & Qtde & $\%$ & Qtde & $\%$ & Qtde & $\%$ \\
\hline Julgamento & 400 & $52,4 \%$ & 60 & $7,9 \%$ & 149 & $19,5 \%$ & 154 & $20,2 \%$ & 763 & $100 \%$ \\
\hline Percepção & 59 & $52,2 \%$ & 7 & $6,2 \%$ & 25 & $22,1 \%$ & 22 & $19,5 \%$ & 113 & $100 \%$ \\
\hline Total & 459 & $52,4 \%$ & 67 & $7,6 \%$ & 174 & $19,9 \%$ & 176 & $20,1 \%$ & 876 & $100 \%$ \\
\hline
\end{tabular}

Quadro 206 - Tabela Cruzada: Julgamento / Percepção vs. Rotativo / Renda

Chi-Square Tests

\begin{tabular}{|c|c|c|c|}
\hline & Value & df & $\begin{array}{l}\text { Asymp. Sig. } \\
\text { (2-sided) }\end{array}$ \\
\hline Pearson Chi-Square & $\begin{array}{r}, 718 \\
876\end{array}$ & 3 & ,869 \\
\hline
\end{tabular}

Quadro 207 - Teste Qui-quadrado: Julgamento / Percepção vs. Rotativo / Renda

Teste Qui-quadrado: Não há evidências que permitam rejeitar a hipótese nula de não associação das variáveis, ou seja, as evidências indicam a independência das variáveis. 
7.2.4 Conclusões Relevantes dos Temperamentos vs. Comportamento de Cartão de Crédito

Embora não se tenham encontrado evidências estatísticas que permitissem rejeitar a hipótese nula de não associação das variáveis dos testes de hipótese realizados, frisa-se a distinta configuração gráfica observada nos Artisans, sugerindo que uma amostra com uma maior quantidade dos mesmos talvez pudesse vir a confirmar estatisticamente uma diferenciação desse temperamento. 


\subsection{Relação Temperamentos vs. Ótica Econômica (Poupança e Consumo)}

\section{ÓTICA DE POUPANÇA:}

Propensão a poupar $=\Sigma$ Investimento / Renda, sendo que "Investimento" refere-se aos volumes médios mensais apurados em período semestral de:

- Conta Corrente;

- Poupança;

- $\mathrm{CDB}$;

- Fundos;

- Previdência;

- Capitalização;

\section{ÓTICA DE CONSUMO:}

Propensão a consumir $=\Sigma$ Crédito $/$ Renda, sendo que $\Sigma$ Crédito refere-se aos volumes médios mensais apurados em período semestral de:

- Compras;

- Rotativo;

- Crédito Pessoal;

- Cheque Especial;

- Empréstimos;

- Renegociação; 
7.3.1 Associações entre Faixas da Graduação das Dimensões dos Temperamentos e as Variáveis de Ótica Econômica

Assim como as variáveis de perfil psicológico, os índices de ótica econômica também foram categorizados, como propósito de se buscar apurar evidências de associações entre elas.

O critério para a categorização dessas variáveis foi o da distribuição dos dados. Segundo (Malhotra; Naresh, 1999), a reespecificação de variáveis envolve a transformação dos dados para criação de novas variáveis ou modificação de variáveis existentes, com o propósito de se criar variáveis que sejam consistentes com o objeto da pesquisa.

As variáveis resultantes da categorização são ordinais e, por esse motivo, foi utilizado o teste Somers'd, semelhante ao teste Qui-Quadrado, porém mais apropriados a esse tipo de variável. 
1ํ Resultado: Aplicações em CDB / Renda vs. Faixa de Graduação

Julgamento / Percepção

=aixa de Graduação J / P * VI CDB / Renda (Banded) Crosstabulation

\begin{tabular}{|c|r|c|r|r|r|r|}
\hline \multirow{2}{*}{} & \multicolumn{3}{|c|}{ VI CDB / Renda (Banded) } & \multicolumn{2}{c|}{} \\
\cline { 2 - 6 } & \multicolumn{2}{|c|}{$<=, 00$} & \multicolumn{2}{|c|}{, $01+$} & \multicolumn{2}{c|}{ Total } \\
\cline { 2 - 6 } & Qtde & \multicolumn{1}{c|}{$\%$} & Qtde & \multicolumn{1}{c|}{$\%$} & Qtde & $\%$ \\
\hline Extremo J & 233 & $78,5 \%$ & 64 & $21,5 \%$ & 297 & $100 \%$ \\
Normal J & 344 & $84,3 \%$ & 64 & $15,7 \%$ & 408 & $100 \%$ \\
Neutro J/P & 47 & $81,0 \%$ & 11 & $19,0 \%$ & 58 & $100 \%$ \\
Normal P & 58 & $82,9 \%$ & 12 & $17,1 \%$ & 70 & $100 \%$ \\
Extremo P & 39 & $90,7 \%$ & 4 & $9,3 \%$ & 43 & $100 \%$ \\
Total & 721 & $82,3 \%$ & 155 & $17,7 \%$ & 876 & $100 \%$ \\
\hline
\end{tabular}

Quadro 208 - Tabela Cruzada: Investimentos em CDB vs. Graduação J-P

\section{Directional Measures}

\begin{tabular}{|ll|r|r|}
\hline & & Value & Approx. Sig. \\
\hline $\begin{array}{l}\text { Ordinal Somers'd } \\
\text { by } \\
\text { Ordinal }\end{array}$ & $\begin{array}{l}\text { Vl CDB / Renda } \\
\text { (Banded) Dependent }\end{array}$ &,- 042 &, 050 \\
\hline
\end{tabular}

Quadro 209 - Somers'd: Investimentos em CDB vs. Graduação J-P

Há evidências que permitem rejeitar a hipótese nula de não associação das variáveis, ou seja, as evidências indicam a associação das variáveis. A associação é negativa.

À medida que o indivíduo passa de extremo Julgamento para extrema Percepção, reduz seu comprometimento de renda com aplicações em CDB (Certificado de Depósito Bancário). Segundo Linden (2000, p.126), um indivíduo com perfil Julgamento prefere que suas finanças sejam gerenciadas de forma planejada e 
procura utilizar o dinheiro como ferramenta de controle e direcionamento da vida. $\mathrm{O}$ perfil Percepção é mais flexível e espontâneo e indivíduos com esse perfil preferem manter-se abertos a novas possibilidades e não delimitados por planejamentos e decisões finais.

Um investimento em CDB segue critérios mais rigorosos, como carências e exigências de aplicações iniciais mais elevadas do que a poupança e, até mesmo, alguns fundos de investimentos. Das aplicações voltadas para pessoa física, é uma das menos sujeitas a riscos e volatilidade, sugerindo-se que o teste estatístico demonstra coerência ao apresentar uma maior concentração de indivíduos com perfil Julgamento nesse tipo de aplicação financeira. 
20 Resultado: Cheque Especial / Renda vs. Faixa de Graduação Extrovertido/ $\underline{\text { Introvertido }}$

\begin{tabular}{|c|c|c|c|c|c|c|c|c|c|c|c|c|}
\hline & \multicolumn{10}{|c|}{ VI Ch Especial / Renda (Banded) } & \multirow{2}{*}{\multicolumn{2}{|c|}{ Total }} \\
\hline & \multicolumn{2}{|c|}{$<=, 00$} & \multicolumn{2}{|c|}{, $01-, 02$} & \multicolumn{2}{|c|}{, $03-, 11$} & \multicolumn{2}{|c|}{, $12-, 25$} & \multicolumn{2}{|c|}{,26+ } & & \\
\hline & Qtde & $\%$ & Qtde & $\%$ & Qtde & $\%$ & Qtde & $\%$ & Qtde & $\%$ & Qtde & $\%$ \\
\hline Extremo E & 51 & $23,5 \%$ & 33 & $15,2 \%$ & 40 & $18,4 \%$ & 47 & $21,7 \%$ & 46 & $21,2 \%$ & 217 & $100 \%$ \\
\hline Normal E & 97 & $20,4 \%$ & 76 & $16,0 \%$ & 101 & $21,2 \%$ & 101 & $21,2 \%$ & 101 & $21,2 \%$ & 476 & $100 \%$ \\
\hline Neutro E/I & 14 & $20,3 \%$ & 16 & $23,2 \%$ & 12 & $17,4 \%$ & 12 & $17,4 \%$ & 15 & $21,7 \%$ & 69 & $100 \%$ \\
\hline Normal I & 19 & $31,7 \%$ & 16 & $26,7 \%$ & 10 & $16,7 \%$ & 6 & $10,0 \%$ & 9 & $15,0 \%$ & 60 & $100 \%$ \\
\hline Extremo I & 17 & $31,5 \%$ & 12 & $22,2 \%$ & 11 & $20,4 \%$ & 10 & $18,5 \%$ & 4 & $7,4 \%$ & 54 & $100 \%$ \\
\hline Total & 198 & $22,6 \%$ & 153 & $17,5 \%$ & 174 & $19,9 \%$ & 176 & $20,1 \%$ & 175 & $20,0 \%$ & 876 & $100 \%$ \\
\hline
\end{tabular}

Quadro 210 - Tabela Cruzada: Cheque Especial vs. Graduação E-I

Directional Measures

\begin{tabular}{|c|c|c|c|}
\hline & & Value & Approx. Sig. \\
\hline $\begin{array}{l}\text { Ordinal by Somers' d } \\
\text { Ordinal }\end{array}$ & $\begin{array}{l}\text { VI Ch Especial / Renda } \\
\text { (Banded) Dependent }\end{array}$ & -,076 & 017, \\
\hline
\end{tabular}

Quadro 211 - Teste Somers'd: Cheque Especial vs. Graduação E-I

Há evidências que permitem rejeitar a hipótese nula de não associação das variáveis, ou seja, as evidências indicam a associação das variáveis.

Os mais extrovertidos concentram-se nas faixas de maior comprometimento da renda com cheque especial. À medida que passa para o extremo de Introversão, a concentração ocorre nas faixas de menor comprometimento da renda com cheque especial.

De acordo com Linden (2000, p.120), os extrovertidos não são propensos a evitar perdas. A afirmação pode ser corroborada pelo testes estatísticos observados 
que mostram a utilização mais intensa do limite de cheque especial por parte dos mais extrovertidos. 
30 Resultado: Cheque Especial / Renda vs. Faixa de Graduação Julgamento /

\section{Percepção}

\begin{tabular}{|c|c|c|c|c|c|c|c|c|c|c|c|c|}
\hline & \multicolumn{10}{|c|}{ VI Ch Especial / Renda (Banded) } & \multirow{2}{*}{\multicolumn{2}{|c|}{ Total }} \\
\hline & \multicolumn{2}{|c|}{$<=, 00$} & \multicolumn{2}{|c|}{,01 - ,02 } & \multicolumn{2}{|c|}{,03-, 11 } & \multicolumn{2}{|c|}{, 12 - 25 } & \multicolumn{2}{|c|}{,26+ } & & \\
\hline & Qtde & $\%$ & Qtde & $\%$ & Qtde & $\%$ & Qtde & $\%$ & Qtde & $\%$ & Qtde & $\%$ \\
\hline Extremo J & 81 & $27,3 \%$ & 64 & $21,5 \%$ & 56 & $18,9 \%$ & 51 & $17,2 \%$ & 45 & $15,2 \%$ & 297 & $100 \%$ \\
\hline Normal J & 87 & $21,3 \%$ & 64 & $15,7 \%$ & 80 & $19,6 \%$ & 85 & $20,8 \%$ & 92 & $22,5 \%$ & 408 & $100 \%$ \\
\hline Neutro J/P & 10 & $17,2 \%$ & 9 & $15,5 \%$ & 16 & $27,6 \%$ & 11 & $19,0 \%$ & 12 & $20,7 \%$ & 58 & $100 \%$ \\
\hline Normal P & 10 & $14,3 \%$ & 9 & $12,9 \%$ & 17 & $24,3 \%$ & 17 & $24,3 \%$ & 17 & $24,3 \%$ & 70 & $100 \%$ \\
\hline Extremo P & 10 & $23,3 \%$ & 7 & $16,3 \%$ & 5 & $11,6 \%$ & 12 & $27,9 \%$ & 9 & $20,9 \%$ & 43 & $100 \%$ \\
\hline Total & 198 & $22,6 \%$ & 153 & $17,5 \%$ & 174 & $19,9 \%$ & 176 & $20,1 \%$ & 175 & $20,0 \%$ & 876 & $100 \%$ \\
\hline
\end{tabular}

Quadro 212 - Tabela Cruzada: Cheque Especial vs. Graduação J-P

\section{Directional Measures}

\begin{tabular}{|c|c|c|c|}
\hline & & Value & Approx. Sig. \\
\hline $\begin{array}{l}\text { Ordinal by Somers'd } \\
\text { Ordinal }\end{array}$ & $\begin{array}{l}\text { VI Ch Especial / Renda } \\
\text { (Banded) Dependent }\end{array}$ & 116 & ,000 \\
\hline
\end{tabular}

Quadro 213 - Somers'd: Cheque Especial vs. Graduação J-P

Há evidências que permitem rejeitar a hipótese nula de não associação das variáveis, ou seja, as evidências indicam a associação das variáveis. A associação é positiva.

À medida que se passa de Julgamento para Percepção, há maior concentração nas maiores faixas de comprometimento da renda com cheque especial. O perfil Percepção é mais espontâneo e menos relacionado a ações controladas e planejadas, podendo assim sugerir a utilização dessa modalidade de crédito "emergencial" com maior intensidade. Já o perfil Julgamento parece comprometer menos sua renda com cheque especial, por se tratar de um indivíduo 
mais relacionado a ações organizadas e planejadas, atendo-se mais a não fazer uso de empréstimos emergenciais que acabam por embutir um maior custo financeiro. 
$\underline{4^{\circ} \text { Resultado: Empréstimos / Renda vs.Faixa de Graduação Extroversão / }}$

$\underline{\text { Introversão }}$

\begin{tabular}{|c|c|c|c|c|c|c|c|c|c|c|}
\hline & \multicolumn{8}{|c|}{ VI Empréstimos / Renda (Banded) } & \multirow{2}{*}{\multicolumn{2}{|c|}{ Total }} \\
\hline & \multicolumn{2}{|c|}{$<=, 00$} & \multicolumn{2}{|c|}{, $01-, 67$} & \multicolumn{2}{|c|}{$, 68-2,91$} & \multicolumn{2}{|c|}{$2,92+$} & & \\
\hline & Qtde & $\%$ & Qtde & $\%$ & Qtde & $\%$ & Qtde & $\%$ & Qtde & $\%$ \\
\hline Extremo E & 106 & $48,8 \%$ & 17 & $7,8 \%$ & 45 & $20,7 \%$ & 49 & $22,6 \%$ & 217 & $100 \%$ \\
\hline Normal E & 233 & $48,9 \%$ & 48 & $10,1 \%$ & 96 & $20,2 \%$ & 99 & $20,8 \%$ & 476 & $100 \%$ \\
\hline Neutro E/I & 33 & $47,8 \%$ & 9 & $13,0 \%$ & 14 & $20,3 \%$ & 13 & $18,8 \%$ & 69 & $100 \%$ \\
\hline Normal I & 37 & $61,7 \%$ & 4 & $6,7 \%$ & 10 & $16,7 \%$ & 9 & $15,0 \%$ & 60 & $100 \%$ \\
\hline Extremo I & 36 & $66,7 \%$ & 2 & $3,7 \%$ & 10 & $18,5 \%$ & 6 & $11,1 \%$ & 54 & $100 \%$ \\
\hline Total & 445 & $50,8 \%$ & 80 & $9,1 \%$ & 175 & $20,0 \%$ & 176 & $20,1 \%$ & 876 & $100 \%$ \\
\hline
\end{tabular}

Quadro 214 - Tabela Cruzada: Empréstimos vs. Graduação E-I

Directional Measures

\begin{tabular}{|c|c|c|c|}
\hline & & Value & Approx. Sig. \\
\hline $\begin{array}{l}\text { Ordinal by Somers' d } \\
\text { Ordinal }\end{array}$ & $\begin{array}{l}\text { VI Empréstimos / Renda } \\
\text { (Banded) Dependent }\end{array}$ &,- 065 & ,030 \\
\hline
\end{tabular}

Quadro 215 - Somers'd: Empréstimos vs. Graduação E-I

Há evidências que permitem rejeitar a hipótese nula de não associação das variáveis, ou seja, as evidências indicam a associação das variáveis. A associação é negativa.

À medida que se observam os indivíduos, dos mais extrovertidos aos mais introvertidos, nota-se também o menor comprometimento da renda com empréstimos ou financiamentos. Vale ressaltar que essa modalidade de crédito contempla valores mais significativos, como aquisição de bens, demonstrando que os mais extrovertidos demandam maior consumo de bens financiados. 
Mais uma vez o teste estatístico apresenta evidências sugerindo que a atitude extrovertida está associada a produtos de crédito e, assim como apresentou maiores índices de comprometimento da renda como cheque especial, também se compromete com empréstimos e financiamentos de bens. 
50 Resultado: Empréstimos / Renda vs. Faixa de Graduação Sensação / $\underline{\text { Intuição }}$

\begin{tabular}{|c|c|c|c|c|c|c|c|c|c|c|}
\hline & \multicolumn{8}{|c|}{ VI Empréstimos / Renda (Banded) } & \multirow{2}{*}{\multicolumn{2}{|c|}{ Total }} \\
\hline & \multicolumn{2}{|c|}{$<=, 00$} & \multicolumn{2}{|c|}{,01-,67 } & \multicolumn{2}{|c|}{$, 68-2,91$} & \multicolumn{2}{|c|}{$2,92+$} & & \\
\hline & Qtde & $\%$ & Qtde & $\%$ & Qtde & $\%$ & Qtde & $\%$ & Qtde & $\%$ \\
\hline Extremo S & 75 & $44,4 \%$ & 12 & $7,1 \%$ & 44 & $26,0 \%$ & 38 & $22,5 \%$ & 169 & $100,0 \%$ \\
\hline Normal S & 110 & $50,5 \%$ & 17 & $7,8 \%$ & 45 & $20,6 \%$ & 46 & $21,1 \%$ & 218 & $100,0 \%$ \\
\hline Neutro S/N & 58 & $52,3 \%$ & 12 & $10,8 \%$ & 20 & $18,0 \%$ & 21 & $18,9 \%$ & 111 & $100,0 \%$ \\
\hline Normal N & 100 & $51,0 \%$ & 18 & $9,2 \%$ & 36 & $18,4 \%$ & 42 & $21,4 \%$ & 196 & $100,0 \%$ \\
\hline Extremo $\mathrm{N}$ & 102 & $56,0 \%$ & 21 & $11,5 \%$ & 30 & $16,5 \%$ & 29 & $15,9 \%$ & 182 & $100,0 \%$ \\
\hline Total & 445 & $50,8 \%$ & 80 & $9,1 \%$ & 175 & $20,0 \%$ & 176 & $20,1 \%$ & 876 & $100,0 \%$ \\
\hline
\end{tabular}

Quadro 216 - Tabela Cruzada: Empréstimos vs. Graduação S-N

Directional Measures

\begin{tabular}{|c|c|c|c|}
\hline & & Value & Approx. Sig. \\
\hline $\begin{array}{l}\text { Ordinal by Somers'd } \\
\text { Ordinal }\end{array}$ & $\begin{array}{l}\text { VI Empréstimos / Renda } \\
\text { (Banded) Dependent }\end{array}$ &,- 060 & ,019 \\
\hline
\end{tabular}

Quadro 217 - Somers'd: Empréstimos vs. Graduação S-N

Há evidências que permitem rejeitar a hipótese nula de não associação das variáveis, ou seja, as evidências indicam a associação das variáveis. A associação é negativa.

À medida que a graduação do perfil passa de Sensação para Intuição, há uma redução no comprometimento da renda com empréstimos ou financiamentos. A tabela indica uma tendência de maior consumo quando o perfil é Sensação. 
60 Resultado: Crédito Pessoal / Renda vs. Faixa de Graduação Extroversão / $\underline{\text { Introversão }}$

\begin{tabular}{|c|c|c|c|c|c|c|c|c|}
\hline & \multicolumn{6}{|c|}{ VI Crédito Pessoal / Renda (Banded) } & \multirow{2}{*}{\multicolumn{2}{|c|}{ Total }} \\
\hline & \multicolumn{2}{|c|}{$<=, 00$} & \multicolumn{2}{|c|}{ 20 } & \multicolumn{2}{|c|}{ 21+ } & & \\
\hline & Qtde & $\%$ & Qtde & $\%$ & Qtde & $\%$ & Qtde & $\%$ \\
\hline Extremo E & 136 & $62,7 \%$ & 31 & $14,3 \%$ & 50 & $23,0 \%$ & 217 & $100 \%$ \\
\hline Normal E & 298 & $62,6 \%$ & 81 & $17,0 \%$ & 97 & $20,4 \%$ & 476 & $100 \%$ \\
\hline Neutro E/I & 41 & $59,4 \%$ & 11 & $15,9 \%$ & 17 & $24,6 \%$ & 69 & $100 \%$ \\
\hline Normal I & 45 & $75,0 \%$ & 11 & $18,3 \%$ & 4 & $6,7 \%$ & 60 & $100 \%$ \\
\hline Extremo I & 44 & $81,5 \%$ & 2 & $3,7 \%$ & 8 & $14,8 \%$ & 54 & $100 \%$ \\
\hline Total & 564 & $64,4 \%$ & 136 & $15,5 \%$ & 176 & $20,1 \%$ & 876 & $100 \%$ \\
\hline
\end{tabular}

Quadro 218 - Tabela Cruzada: Crédito Pessoal vs. Graduação E-I

\section{Directional Measures}

\begin{tabular}{|c|c|c|c|}
\hline & & Value & Approx. Sig. \\
\hline $\begin{array}{ll}\text { Ordinal by } & \text { Somers' d } \\
\text { Ordinal } & \end{array}$ & $\begin{array}{l}\text { VI Crédito Pessoal / } \\
\text { Renda (Banded) } \\
\text { Dependent }\end{array}$ &,- 056 & , 038 \\
\hline
\end{tabular}

\section{Quadro 219 - Somers'd: Crédito Pessoal vs. Graduação E-I}

Há evidências que permitem rejeitar a hipótese nula de não associação das variáveis, ou seja, as evidências indicam a associação das variáveis. A associação é negativa.

À medida que passa das maiores graduações da atitude Extroversão para as maiores graduações de Introversão, há redução no comprometimento da renda com crédito pessoal. Os mais extrovertidos possuem maior tendência a comprometer sua renda com esta modalidade de crédito. 
$\underline{7^{0} \text { Resultado: Previdência / Renda vs. Faixas de Graduação de Extroversão/ }}$ $\underline{\text { Introversão }}$

\begin{tabular}{|c|r|c|r|r|r|r|}
\hline \multirow{2}{*}{} & \multicolumn{2}{|c|}{ VI Previdência / Renda (Banded) } & \multicolumn{2}{|c|}{} \\
\cline { 2 - 5 } & \multicolumn{2}{|c|}{$<=, 00$} & \multicolumn{2}{|c|}{$01+$} & \multicolumn{2}{c|}{ Total } \\
\cline { 2 - 5 } & Qtde & \multicolumn{1}{c|}{$\%$} & Qtde & \multicolumn{1}{c|}{$\%$} & Qtde & $\%$ \\
\hline Extremo E & 214 & $98,6 \%$ & 3 & $1,4 \%$ & 217 & $100 \%$ \\
Normal E & 458 & $96,2 \%$ & 18 & $3,8 \%$ & 476 & $100 \%$ \\
Neutro E/I & 66 & $95,7 \%$ & 3 & $4,3 \%$ & 69 & $100 \%$ \\
Normal I & 55 & $91,7 \%$ & 5 & $8,3 \%$ & 60 & $100 \%$ \\
Extremo I & 53 & $98,1 \%$ & 1 & $1,9 \%$ & 54 & $100 \%$ \\
Total & 846 & $96,6 \%$ & 30 & $3,4 \%$ & 876 & $100 \%$ \\
\hline
\end{tabular}

Quadro 220 - Tabela Cruzada: Previdência vs. Graduação E-I

Directional Measures

\begin{tabular}{|c|c|c|c|}
\hline & & Value & Approx. Sig. \\
\hline $\begin{array}{l}\text { Ordinal by Somers' d } \\
\text { Ordinal }\end{array}$ & $\begin{array}{l}\text { VI Previdência / Renda } \\
\text { (Banded) Dependent }\end{array}$ & ,020 & ,04 \\
\hline
\end{tabular}

Quadro 221 - Somers'd: Previdência vs. Graduação E-I

Há evidências que permitem rejeitar a hipótese nula de não associação das variáveis, ou seja, as evidências indicam a associação das variáveis. A associação é positiva.

À medida que a graduação da atitude passa da extremamente extrovertida para a extremamente introvertida, aumenta a incidência do comprometimento da renda com previdência, com exceção dos extremamente introvertidos, cujo percentual é inferior aos demais. 
8 Resultado: Consumo/Renda vs. Faixa de graduação de Extroversão/Introversão

\begin{tabular}{|c|c|c|c|c|c|c|c|c|c|c|}
\hline & \multicolumn{8}{|c|}{ Faixa de Propensão a Consumir } & \multirow{2}{*}{\multicolumn{2}{|c|}{ Total }} \\
\hline & \multicolumn{2}{|c|}{$<=, 23$} & \multicolumn{2}{|c|}{,24 - 1,01 } & \multicolumn{2}{|c|}{$1,02-3,63$} & \multicolumn{2}{|c|}{$3,64+$} & & \\
\hline & Qtde & $\%$ & Qtde & $\%$ & Qtde & $\%$ & Qtde & $\%$ & Qtde & $\%$ \\
\hline Extremo E & 47 & $21,7 \%$ & 60 & $27,6 \%$ & 48 & $22,1 \%$ & 62 & $28,6 \%$ & 217 & $100 \%$ \\
\hline Normal E & 110 & $23,1 \%$ & 115 & $24,2 \%$ & 130 & $27,3 \%$ & 121 & $25,4 \%$ & 476 & $100 \%$ \\
\hline Neutro E/I & 23 & $33,3 \%$ & 12 & $17,4 \%$ & 18 & $26,1 \%$ & 16 & $23,2 \%$ & 69 & $100 \%$ \\
\hline Normal I & 20 & $33,3 \%$ & 16 & $26,7 \%$ & 13 & $21,7 \%$ & 11 & $18,3 \%$ & 60 & $100 \%$ \\
\hline Extremo I & 19 & $35,2 \%$ & 16 & $29,6 \%$ & 10 & $18,5 \%$ & 9 & $16,7 \%$ & 54 & $100 \%$ \\
\hline Total & 219 & $25,0 \%$ & 219 & $25,0 \%$ & 219 & $25,0 \%$ & 219 & $25,0 \%$ & 876 & $100 \%$ \\
\hline
\end{tabular}

Quadro 222 - Tabela Cruzada: Propensão a Consumir vs. Graduação E-I

Directional Measures

\begin{tabular}{|lrl|c|r|}
\hline & & Value & Approx. Sig. \\
\hline Ordinal by Ordinal & Somers' d & $\begin{array}{l}\text { Faixa de Propensão a } \\
\text { Consumir Dependent }\end{array}$ &,- 082 &, 009 \\
\hline
\end{tabular}

Quadro 223 - Somers'd: Propensão a Consumir vs. Graduação E-I

Há evidências que permitem rejeitar a hipótese nula de não associação das variáveis, ou seja, as evidências indicam a associação das variáveis. A associação é negativa.

Conforme observado nos testes anteriores, decresce o comprometimento da renda com créditos tomados à medida que a escala das atitudes passa dos mais extrovertidos aos mais introvertidos, nessa ordem, daí o percentual negativo da estatística de teste. 
go Resultado: Consumo/Renda vs. Faixa de Graduação de Sensação /Intuição

\begin{tabular}{|c|c|c|c|c|c|c|c|c|c|c|}
\hline & \multicolumn{8}{|c|}{ Faixa de Propensão a Consumir } & & \\
\hline & \multicolumn{2}{|c|}{$<=, 23$} & \multicolumn{2}{|c|}{$, 24-1,01$} & \multicolumn{2}{|c|}{$1,02-3,63$} & \multicolumn{2}{|c|}{$3,64+$} & \multicolumn{2}{|c|}{ Total } \\
\hline & Qtde & $\%$ & Qtde & $\%$ & Qtde & $\%$ & Qtde & $\%$ & Qtde & $\%$ \\
\hline Extremo S & 38 & $22,5 \%$ & 37 & $21,9 \%$ & 44 & $26,0 \%$ & 50 & $29,6 \%$ & 169 & $100 \%$ \\
\hline Normal S & 51 & $23,4 \%$ & 53 & $24,3 \%$ & 60 & $27,5 \%$ & 54 & $24,8 \%$ & 218 & $100 \%$ \\
\hline Neutro S/N & 27 & $24,3 \%$ & 29 & $26,1 \%$ & 29 & $26,1 \%$ & 26 & $23,4 \%$ & 111 & $100 \%$ \\
\hline Normal N & 38 & $19,4 \%$ & 62 & $31,6 \%$ & 47 & $24,0 \%$ & 49 & $25,0 \%$ & 196 & $100 \%$ \\
\hline Extremo $\mathrm{N}$ & 65 & $35,7 \%$ & 38 & $20,9 \%$ & 39 & $21,4 \%$ & 40 & $22,0 \%$ & 182 & $100 \%$ \\
\hline Total & 219 & $25,0 \%$ & 219 & $25,0 \%$ & 219 & $25,0 \%$ & 219 & $25,0 \%$ & 876 & $100 \%$ \\
\hline
\end{tabular}

Quadro 224 - Tabela Cruzada: Propensão a Consumir vs. Graduação S-N

\section{Directional Measures}

\begin{tabular}{|c|c|c|c|}
\hline & & Value & Approx. Sig. \\
\hline $\begin{array}{l}\text { Ordinal by Somers'd } \\
\text { Ordinal }\end{array}$ & $\begin{array}{l}\text { Faixa de Propensão a } \\
\text { Consumir Dependent }\end{array}$ &,- 068 & ,015 \\
\hline
\end{tabular}

Quadro 225 - Somers'd: Propensão a Consumir vs. Graduação S-N

Há evidências que permitem rejeitar a hipótese nula de não associação das variáveis, ou seja, as evidências indicam a associação das variáveis. A associação é negativa.

Por conseqüência dos testes anteriormente observados, há uma associação entre comprometimento da renda com empréstimos e as graduações das funções Sensação/intuição. À medida que passa a ter maior graduação na função Intuição, reduz também o comprometimento da renda com consumo, já que as concentrações dos indivíduos de maior graduação da função Intuição ocorrem nas menores faixas de Consumo/Renda. 


\subsubsection{Conclusões Relevantes dos Temperamentos vs. Ótica Econômica}

Pelas associações anteriormente observadas, verifica-se que há evidências estatísticas que indicam a existência de relações entre o perfil financeiro dos indivíduos e a intensidade da dimensão dos temperamentos.

Quanto maior o grau de Extroversão dos indivíduos, maior o comprometimento da renda com produtos de crédito: cheque especial, empréstimos e financiamentos e crédito pessoal. Evidências estatísticas sugerem também haver uma associação entre os investimentos em previdência privada e a atitude introvertida, indicando que o extrovertido tem menos tendência à poupança dessa natureza. Segundo Linden (2000, p.120), os extrovertidos não são propensos a evitar perdas e, já os introvertidos, tem propensão a evitar perdas. Evidências mostram que os indivíduos com atitude Extrovertida têm maior tendência ao consumo, apresentando-se como tomadores de crédito de diversas modalidades, e os introvertidos tem maior tendência a investimentos como previdência privada.

Há outras duas questões a serem observadas quanto ao comprometimento da renda com crédito. A primeira, quando o perfil é Sensação, há uma associação que indica maior consumo de empréstimos ou financiamentos, que são produtos de crédito para aquisição de bens. Linden (2000, p. 114), em suas descrições das características do comportamento financeiro dos indivíduos com perfil dominante Sensação, define que os de perfil Sensação orientam suas finanças para resultados tangíveis a curto prazo, sacrificando ganhos futuros e não perdendo tempo analisando soluções. Essa característica pode ser denotada pelo fato que financiam 
bens para adquiri-los. O perfil dominante Intuição, com menor incidência de comprometimento da renda com financiamento de bens, ao contrário do perfil Sensação, prefere sacrificar o presente e orientar suas finanças para obtenção de recurso financeiro suficiente para o que aspira no futuro.

A segunda questão, quanto relação entre as dimensões Julgamento e Percepção e a utilização de cheque especial. Quando a escala da dimensão passa do extremo Julgamento ao extremo Percepção, há maior incidência de perfil Percepção nas faixas mais elevadas de comprometimento da renda com utilização de cheque especial. As características do perfil Percepção, conforme Linden (2000, p. 87), são mais voltados para a flexibilidade e o mínimo de planejamento, o que se pode associar ao fato desse perfil ser mais incidente em uma modalidade de crédito "emergencial", como é o caso do cheque especial.

Em contrapartida, aumenta a incidência de investimentos em CDB à medida que o indivíduo atinge maiores graduações de perfil Julgamento. Indivíduos com esse perfil, de acordo com Linden (2000, p. 87) são voltados para o planejamento, organização e controle, fato que pode estar associado a maior incidência de investimentos.

Considerando-se que há evidências que permitem rejeitar a hipótese nula de não associação entre tipos psicológicos e determinados comportamentos financeiros, é importante identificar-se quais abordagens mercadológicas devem ser utilizadas para cada segmento visando uma melhor aceitação de uma oferta específica de serviço financeiro voltada para cada tipo da população, resultando 
numa maior sintonia entre a oferta e a demanda de serviços financeiros, maior assertividade e precisão na oferta, aprimoramento do CRM, melhor qualidade na prestação de serviços, maximizando-se assim a condição diferenciada de se conhecer o cliente antes do mesmo iniciar sua transação quando o acesso é feito pelos canais eletrônicos.

\subsection{Relação Temperamentos vs. Desempenho Profissional}

Neste item apresenta-se o resultado do estudo de associações entre as variáveis de desempenho profissional e as variáveis de perfil psicológico.

As pontuações são medidas de 0 a $100 \%$. A avaliação do Desempenho refere-se a uma avaliação geral composta pela Qualidade do Atendimento, Desempenho Comercial e Produtividade.

A análise foi efetuada para as variáveis de desempenho profissional em sua forma categórica quando se buscou associá-las com as variáveis categóricas de perfil psicológico e das graduações de suas dimensões. 


\subsubsection{Desempenho Comercial vs. Perfil Psicológico}

Resultado: Faixas de Desempenho Comercial vs. Faixa de Graduação E-I

\begin{tabular}{|c|r|r|r|r|r|r|r|r|}
\hline \multirow{2}{*}{} & \multicolumn{6}{|c|}{ DESEMPENHO COMERCIAL } & \multicolumn{2}{c|}{} \\
\cline { 2 - 8 } & \multicolumn{2}{|c|}{$<=, 417$} & \multicolumn{1}{c|}{, $418-, 764$} & \multicolumn{2}{c|}{$, 765-1,000$} & \multicolumn{2}{c|}{ Total } \\
\cline { 2 - 8 } & Qtde & \multicolumn{1}{|c}{$\%$} & Qtde & \multicolumn{1}{c|}{$\%$} & Qtde & $\%$ & Qtde & $\%$ \\
\hline Extremo E & 45 & $22,0 \%$ & 45 & $22,0 \%$ & 115 & $56,1 \%$ & 205 & $100,0 \%$ \\
Normal E & 122 & $27,8 \%$ & 90 & $20,5 \%$ & 227 & $51,7 \%$ & 439 & $100,0 \%$ \\
Neutro E/I & 23 & $35,9 \%$ & 15 & $23,4 \%$ & 26 & $40,6 \%$ & 64 & $100,0 \%$ \\
Normal I & 15 & $28,8 \%$ & 20 & $38,5 \%$ & 17 & $32,7 \%$ & 52 & $100,0 \%$ \\
Extremo I & 16 & $30,8 \%$ & 16 & $30,8 \%$ & 20 & $38,5 \%$ & 52 & $100,0 \%$ \\
Total & 221 & $27,2 \%$ & 186 & $22,9 \%$ & 405 & $49,9 \%$ & 812 & $100,0 \%$ \\
\hline
\end{tabular}

Quadro 226 -Tabela Cruzada: Desempenho Comercial vs. Graduação E-I

Directional Measures

\begin{tabular}{|lll|c|r|}
\hline & & Value & Approx. Sig. \\
\hline Ordinal by Ordinal & Somers' d & $\begin{array}{l}\text { DESEMPENHO } \\
\text { COMERCIAL Dependent }\end{array}$ &,- 101 &, 001 \\
\hline
\end{tabular}

Quadro 227 - Somers'd: Desempenho Comercial vs. Graduação E-I

Há evidências que permitem rejeitar a hipótese nula de não associação das variáveis, ou seja, as evidências indicam a associação das variáveis. A associação é negativa.

Os indivíduos mais extrovertidos apresentaram-se mais concentrados nas maiores pontuações quanto ao seu Desempenho Comercial. À medida que diminui a graduação de Extroversão e aumenta a graduação de Introversão, a performance comercial é reduzida. 


\subsubsection{Avaliação do Desempenho vs. Perfil Psicológico}

Resultado: Faixas de Avaliação de Desempenho vs. Faixa de Graduação E-I

\begin{tabular}{|c|c|c|c|c|c|c|c|c|c|c|}
\hline & \multicolumn{8}{|c|}{ AVALIAÇÃO DE DESEMPENHO } & \multirow{2}{*}{\multicolumn{2}{|c|}{ Total }} \\
\hline & \multicolumn{2}{|c|}{$<=, 70$} & \multicolumn{2}{|c|}{, $71-, 81$} & \multicolumn{2}{|c|}{,82 - , 88 } & \multicolumn{2}{|c|}{,89+ } & & \\
\hline & Qtde & $\%$ & Qtde & $\%$ & Qtde & $\%$ & Qtde & $\%$ & Qtde & $\%$ \\
\hline Extremo E & 41 & $19,8 \%$ & 44 & $21,3 \%$ & 60 & $29,0 \%$ & 62 & $30,0 \%$ & 207 & $100 \%$ \\
\hline Normal E & 108 & $24,4 \%$ & 115 & $26,0 \%$ & 112 & $25,3 \%$ & 108 & $24,4 \%$ & 443 & $100 \%$ \\
\hline Neutro E/I & 25 & $39,1 \%$ & 13 & $20,3 \%$ & 13 & $20,3 \%$ & 13 & $20,3 \%$ & 64 & $100 \%$ \\
\hline Normal I & 15 & $28,3 \%$ & 18 & $34,0 \%$ & 10 & $18,9 \%$ & 10 & $18,9 \%$ & 53 & $100 \%$ \\
\hline Extremo I & 16 & $30,8 \%$ & 15 & $28,8 \%$ & 10 & $19,2 \%$ & 11 & $21,2 \%$ & 52 & $100 \%$ \\
\hline Total & 205 & $25,0 \%$ & 205 & $25,0 \%$ & 205 & $25,0 \%$ & 204 & $24,9 \%$ & 819 & $100 \%$ \\
\hline
\end{tabular}

Quadro 228 - Tabela Cruzada: Avaliação de Desempenho vs. Graduação E-I

\section{Directional Measures}

\begin{tabular}{|c|c|c|c|c|}
\hline & & & Value & Approx. Sig. \\
\hline $\begin{array}{l}\text { Ordinal by } \\
\text { Ordinal }\end{array}$ & Somers' d & $\begin{array}{l}\text { AVALIAÇÃO DE } \\
\text { DESEMPENHO } \\
\text { Dependent }\end{array}$ &,- 117 & ,000 \\
\hline
\end{tabular}

Quadro 229 - Somers'd: Avaliação de Desempenho vs. Graduação E-I

Há evidências que permitem rejeitar a hipótese nula de não associação das variáveis, ou seja, as evidências indicam a associação das variáveis. A associação é negativa.

A Avaliação de Desempenho resulta das pontuações em Qualidade de Atendimento, Desempenho Comercial e Produtividade. Portanto, o teste estatístico apresenta evidências de que, à medida que a atitude passa das maiores graduações de Extroversão para as maiores graduações de Introversão, diminui o desempenho geral dos atendentes. 


\subsubsection{Conclusões Relevantes do Perfil Psicológico vs. Desempenho} Profissional

Pelos testes anteriormente observados, há evidências de que a avaliação do desempenho do atendente, impulsionada pelo Desempenho Comercial, aumenta conforme a graduação da atitude passa da mais introvertida para a mais extrovertida.

Não houve evidências que comprovassem que há relação entre os itens de Produtividade e Qualidade do Atendimento com o perfil psicológico.

Linden (2000, p. 83) define que os extrovertidos gostam de se comunicar verbalmente, demonstram suas opiniões rapidamente e preferem trabalhar trocando informações e direcionando sua atenção para o mundo externo das pessoas, lugares, coisas e atividades.

As evidências mostraram que essa atitude comunicativa tem relação com o melhor desempenho nos contatos telefônicos com clientes 


\section{CONCLUSÕES FINAIS}

O modelo de logística de distribuição encontra-se em processo de revisão no contexto econômico. A tecnologia, a reconfiguração das atuais demandas de consumo, como também a geração de novas demandas resultam na busca de soluções alternativas para a aproximação dos agentes que ofertam e demandam na economia. Se era comum dizer-se que "A necessidade é a mãe das invenções", o salto no patamar tecnológico apresenta-se com tamanha magnitude que já é possível afirmar-se de maneira inversa que "A invenção é a mãe das necessidades". O advento do celular é um exemplo que atesta essa constatação.

Considerado um dos dispositivos eletrônicos que conquistou a população em esfera global com fantástica velocidade, o celular transformou-se em nova necessidade e atingiu a marca de 50 milhões de usuários em cinco anos. A televisão precisou de treze anos para atingir público semelhante e o rádio, 38 anos. Em "A Máquina que mudou o mundo" Womack e Jones (1990), citam o modelo de produção de enxuta, adotado inicialmente pela indústria automobilística no Japão e seus efeitos na economia mundial, com profundas mudanças sociais e culturais.

Avaliando-se o cenário econômico atual, sem dúvida podemos afirmar que o celular candidata-se a ser a "máquina que está mudando o mundo II", com seus 2,7 bilhões de aparelhos em funcionamento no mundo, o que representa $38 \%$ da população global. 
A máquina que mudou o mundo II, está se tornando um dos maiores promotores da convergência e da mobilidade que os consumidores do século XXI estão presenciando, sendo agente da interação colaborativa entre empresas, quando do desenvolvimento de mais uma função a ser acoplada em seu maravilhoso "chassi", que suporta as mais variadas aplicações, no âmbito do entretenimento, serviços, utilidade pública, informação, lazer, cultura, disponíveis a qualquer hora e em qualquer lugar.

Por outro lado, temos os consumidores diretos, que assistem a uma verdadeira batalha das operadoras de telefonia e demais provedores de conteúdo digital, na conquista de sua fidelidade, assumindo papel de extremo destaque protagonizando uma verdadeira avalanche no consumo de aparelhos e de seus serviços agregados, o que coloca os consumidores, dentro da mais ampla visão do mundo de forma colaborativa.

A indústria financeira de varejo em particular não está alheia a essa tendência e vive um momento de grande transformação.

Nesse contexto, temos um cenário com competidores extremamente ágeis, motivados pela igualdade das atuais condições tecnológicas, que para o mundo virtual, deixam a cada dia mais próximas as grandes corporações, dos pequenos empreendedores em âmbito global.

Apostando no diferencial competitivo de possuir todo o fluxo de clientes préidentificado, acessando os canais de relacionamento remotos que representam na 
atualidade em torno de $85 \%$ do total de transações realizadas, torna-se fator decisivo para as grandes instituições financeiras, a revisão de seu posicionamento diante da nova logística de distribuição bancária (Febraban, 2006)

Os aspectos básicos do relacionamento cliente x banco, como conveniência, segurança e facilidade de uso, tornam-se poderosos pré-requisitos, porém fazer uso adequado do fluxo de clientes pré-identificados poderá se converter em significativa vantagem competitiva para as instituições financeiras que detém um conhecimento mais estruturado de seus clientes, permitindo-Ihes antecipar necessidades e otimizar o relacionamento com os mesmos. Assim sendo, o presente trabalho visou apurar evidências de associação entre o perfil psicológico dos clientes da instituição financeira e sua utilização de serviços financeiros, como forma de contribuir para uma melhor interpretação dos padrões de comportamento financeiro, associados aos tipos psicológicos.

Essa perspectiva permite a inserção de novas variáveis aos atuais modelos de segmentação de clientes, enriquecendo o ferramental do CRM ao dotá-lo de um poder de maior assertividade nas iniciativas de aprimoramento e satisfação das necessidades de seus clientes.

O presente estudo teve como finalidade testar as seguintes hipóteses:

a. Há correlação entre os tipos psicológicos e os hábitos de consumo de cartão de crédito. 
b. Há correlação entre as propensões a poupar e a consumir e os tipos psicológicos.

c. O desempenho profissional, caracterizado pela performance comercial, produtividade e qualidade de atendimento, está correlacionado com os tipos psicológicos. 
O Quadro 230 - Resultados das Associações resume as evidências de relações encontradas nos testes estatísticos:

\begin{tabular}{|c|c|}
\hline \multicolumn{2}{|c|}{ PERFIL DEMOGRÁFICO } \\
\hline 4 Temperamentos & \multirow{3}{*}{ Sexo } \\
\hline 16 Tipos & \\
\hline Sentimento-Pensamento & \\
\hline 4 Temperamentos & \multirow{3}{*}{ Faixa Etária } \\
\hline 16 Tipos & \\
\hline Sensação-Intuição & \\
\hline \multicolumn{2}{|c|}{ UTILIZAÇÃO DE PRODUTOS E SERVIÇOS } \\
\hline \multirow{4}{*}{ Extroversão-Introversão } & Capitalização \\
\hline & Cheque Especial \\
\hline & Empréstimos/Financiamentos \\
\hline & Cartão de Crédito \\
\hline \multicolumn{2}{|c|}{ ÓTICA ECONÔMICA } \\
\hline \multirow{5}{*}{$\begin{array}{l}\text { Faixa de Graduação Extroversão- } \\
\text { Introversão }\end{array}$} & Cheque Especial / Renda \\
\hline & Empréstimos e Financiamentos / Renda \\
\hline & Crédito Pessoal / Renda \\
\hline & Previdência / Renda \\
\hline & Propensão a Consumir \\
\hline \multirow{2}{*}{$\begin{array}{l}\text { Faixa de Graduação Sensação - } \\
\text { Intuição }\end{array}$} & Empréstimos e Financiamentos / Renda \\
\hline & Propensão a Consumir \\
\hline \multirow{2}{*}{$\begin{array}{l}\text { Faixa de Graduação Julgamento- } \\
\text { Percepção }\end{array}$} & Cheque Especial / Renda \\
\hline & Aplicação em CDB / Renda \\
\hline \multicolumn{2}{|c|}{ DESEMPENHO PROFISSIONAL } \\
\hline \multirow{2}{*}{$\begin{array}{l}\text { Faixa de Graduação Extroversão- } \\
\text { Introversão }\end{array}$} & Desempenho Comercial \\
\hline & Avaliação de Desempenho \\
\hline
\end{tabular}

Quadro 230 - Resultados das Associações

Ao se avaliar a relação entre os tipos psicológicos e a utilização de produtos e serviços financeiros, observa-se que apenas as atitudes Extroversão - Introversão 
apresentam-se como variáveis independentes com poder de explicação para o uso de capitalização, cheque especial, empréstimos/financiamentos e cartão de crédito.

Com relação à capitalização, observa-se que aqueles indivíduos que possuem títulos do produto estão mais concentrados na atitude Extrovertida do que na atitude Introvertida.

Ressalte-se que a capitalização é uma economia programada, vinculada a sorteios na qual, no vencimento do título, o cliente receberá o valor pago atualizado monetariamente.

Encontramos assim evidências estatísticas não nos permitem rejeitar as seguintes hipóteses:

Os extrovertidos apresentam maior utilização de cartão de crédito do que os introvertidos;

À medida que a atitude se altera de introvertida para extrovertida, altera-se também o percentual de uso do cheque especial. O percentual de usuários que utilizam o limite do cheque especial é maior entre os extrovertidos;

Os indivíduos extrovertidos possuem mais empréstimos e financiamentos do que os introvertidos. 
Em síntese, os indivíduos extrovertidos apresentam tendência ao consumo superior aos introvertidos, pois apresentam associação com a utilização de produtos de crédito como Cheque Especial, Empréstimos/Financiamentos e Cartão de Crédito.

A primeira hipótese formulada para esse estudo era de que havia correlação entre os tipos psicológicos e os hábitos de consumo de cartão de crédito, hipótese essa confirmada pela evidência estatística de associação do uso de cartão de crédito com a atitude Extroversão, conforme se pode apresentar ao longo do trabalho.

A segunda hipótese concentrou-se na ótica econômica, focando indicadores relacionados às propensões a poupar e a consumir, buscando associá-las aos tipos psicológicos.

Novamente ressalta-se o poder de explicação das atitudes Extroversão Introversão no concernente à impossibilidade de rejeição da não associação das mesmas com os indicadores Cheque Especial / Renda, Empréstimos e Financiamentos / Renda, Crédito Pessoal / Renda, Propensão a Consumir / Renda e Previdência / Renda.

Constata-se assim que na medida em que aumenta o grau de Extroversão dos indivíduos, cresce o comprometimento de sua renda com produtos de crédito: cheque especial, empréstimos e financiamentos e crédito pessoal. 
Evidências estatísticas indicam também haver uma associação entre os investimentos em previdência privada e a atitude introvertida, sugerindo que o indivíduo extrovertido tem menor propensão à poupança dessa natureza.

LINDEN (2000, p.120) afirma que os extrovertidos não são propensos a evitar perdas enquanto os introvertidos têm propensão a evitá-las. Evidências mostram que os indivíduos com perfil extrovertido têm maior tendência ao consumo, apresentando-se como tomadores de crédito de diversas modalidades, e os introvertidos tem maior tendência a investimentos como previdência privada.

Segundo a ótica econômica, pode-se observar a indicação de associações entre as funções Sensação - Intuição e os indicadores de comprometimento da renda com Empréstimos e Financiamentos e Propensão a Consumir.

À medida que a graduação do perfil passa da função Sensação para a função Intuição, há uma redução no comprometimento da renda com empréstimos e financiamentos, como também na propensão a consumir, tendo em vista que as concentrações dos indivíduos com função Intuição de graduação mais elevada ocorrem nas menores faixas de Empréstimos e Financiamentos/Renda e Consumo/Renda.

Linden (2000, p. 114), ao descrever algumas das características do comportamento financeiro dos indivíduos com prevalência da função Sensação, define que esses indivíduos orientam suas finanças para resultados tangíveis a curto prazo, sacrificando ganhos futuros e não alocando seu tempo para analisar soluções. 
Essa característica pode ser denotada pelo fato que os mesmos financiam bens para possuí-los. Já quando a função prevalente é a Intuição, observa-se a menor incidência de comprometimento da renda com financiamento de bens, pois ao contrário do perfil Sensação, o indivíduo prefere sacrificar o presente e orientar suas finanças para obtenção do recurso financeiro necessário para adquirir o que deseja no futuro.

As dimensões Julgamento - Percepção apresentaram evidências de associação com os indicadores de comprometimento da renda com o uso de cheque especial e de aplicação em CDB, utilizados para a avaliação do comportamento segundo a ótica econômica.

O comprometimento da renda com utilização de cheque especial aumenta na medida em que os indivíduos se deslocam da dimensão Julgamento para a dimensão Percepção.

Conforme cita Linden (2000, p. 87), na dimensão Percepção, os indivíduos são mais voltados para a flexibilidade e menor exercício de planejamento, podendose vincular esse fato à observação de ser essa dimensão mais incidente em uma modalidade de crédito "emergencial", de maior custo financeiro em razão de se tratar um recurso colocado à disposição do cliente que pode ser utilizado sem prévio aviso, como é o caso do cheque especial. 
Ao se avaliar a parcela da renda destinada à aplicação de recursos em CDB, constata-se o aumento da incidência da mesma à medida que o indivíduo atinge maiores graduações de perfil Julgamento.

A dimensão Julgamento encontra-se associada de acordo com Linden (2000, p. 87) para o planejamento, organização e controle, justificando-se assim a maior incidência de investimentos.

Linden (2000, p.126) acrescenta que um indivíduo com a prevalência dessa dimensão tem preferência pelo gerenciamento de forma planejada de seus recursos e procura fazer uso do dinheiro e de sua alocação como ferramenta de controle e direcionamento de sua vida.

Dentre as aplicações financeiras, a aplicação em CDB é uma das menos sujeitas a riscos, constata-se, portanto, segundo essa ótica, coerência ao se apurar como resultado do teste estatístico, uma maior concentração de indivíduos com dimensão Julgamento nesse tipo de aplicação financeira.

Foram identificadas no presente estudo nove evidências que impediram a rejeição da segunda hipótese formulada no estudo, de não haver correlação entre as propensões para poupar e consumir e os tipos psicológicos.

A avaliação dessa hipótese procurou centrar-se na busca de associações de indicadores da ótica econômica e tipos psicológicos. Houve evidências de que há relação entre a graduação das atitudes Extroversão-Introversão, das funções 
Sensação-Intuição e das dimensões Julgamento-Percepção e indicadores da ótica econômica.

A terceira e última hipótese formulada na presente pesquisa buscou apurar a associação entre o desempenho profissional, caracterizado pela performance comercial, produtividade e qualidade de atendimento e os tipos psicológicos.

Houve evidências estatísticas que permitiram a rejeição da hipótese nula de não associação do desempenho comercial e a avaliação de desempenho com a graduação do eixo Extroversão-Introversão.

Os testes estatísticos apresentaram evidências de que, à medida que a atitude passa das maiores graduações de Extroversão para as maiores graduações de Introversão, diminuem o desempenho profissional e a performance comercial dos atendentes.

A Avaliação de Desempenho resulta das pontuações obtidas pelo atendente em Qualidade de Atendimento, Desempenho Comercial e Produtividade, representando o desempenho profissional do mesmo.

De acordo com Linden (2000, p. 83), os extrovertidos apreciam a comunicação verbal e demonstram suas opiniões rapidamente, preferindo trabalhar trocando informações e direcionando sua atenção para o mundo externo das pessoas, lugares, coisas e atividades. 
A função do atendente de call center é bastante pautada em atividades que privilegiam a atitude de Extroversão, tendo as evidências estatísticas apresentadas sugerido que a incidência desse perfil comunicativo tem relação com o melhor desempenho nos contatos telefônicos com clientes, naturais dessa atividade profissional.

É importante frisar-se que a amostra de atendentes considerada, por ser composta de funcionários de uma instituição financeira de varejo, submeteu-se a critérios específicos de recrutamento e seleção daquela instituição, resultando num grupo com características comuns em determinados quesitos tais como escolaridade, idade, salário, entre outros, fato que pode introduzir algum viés nas generalizações das conclusões aqui apuradas.

Elementos de cultura organizacional conferem características particulares a cada instituição e norteiam regras e procedimentos de conduta, conferindo uma condição específica para cada empresa, ainda que a mesma atue num segmento bastante regulamentado, como é o caso das instituições financeiras de varejo.

Assim sendo, tanto no que diz respeito aos critérios de recrutamento e seleção, quanto no concernente aos elementos da cultura organizacional que são experimentados e configuram traços da operação do call center propriamente dita, há que se considerar que as possíveis generalizações das hipóteses testadas nesse estudo devem respeitar o contexto no qual foram apuradas. 


\section{SUGESTÕES PARA PESQUISAS FUTURAS}

São diversos os temas que derivam do presente estudo que suscitam um aprofundamento ou sugerem novas fronteiras para pesquisas. Relacionam-se a seguir um conjunto de propostas com esse objetivo.

Artisans apresentam um hábito diferente de uso de cartão de crédito dos demais temperamentos?

Linden (2000; p.124) classifica os Artisans como Players e observa que "As one player put it, Anything I want I just put on the charge account. Years ago I did overextend. I'm more the take-a-chance personality. What have I got to loose - it's only money! Life is to be enjoyed". Assim sendo, esse temperamento apresenta um comportamento mais "desprendido" no que se refere ao trato com o dinheiro.

Embora as evidências estatísticas não tenham podido confirmar essa diferenciação, a comparação gráfica permite a visualização de uma concentração em patamares de maiores volumes de compras com cartão de crédito, como também em maiores comprometimentos de renda com gastos com cartão de crédito.

A seqüência de gráficos de volume de compras e comprometimento de renda com gastos com cartão de crédito destaca as diferenças citadas anteriormente e reforça a sugestão de que uma amostra com maior número de representantes do temperamento Artisan poderá vir a apresentar evidências que permitam verificar estatisticamente essa diferenciação. 
Análise Gráfica: Os 4 Temperamentos vs. Volume Médio de Compras

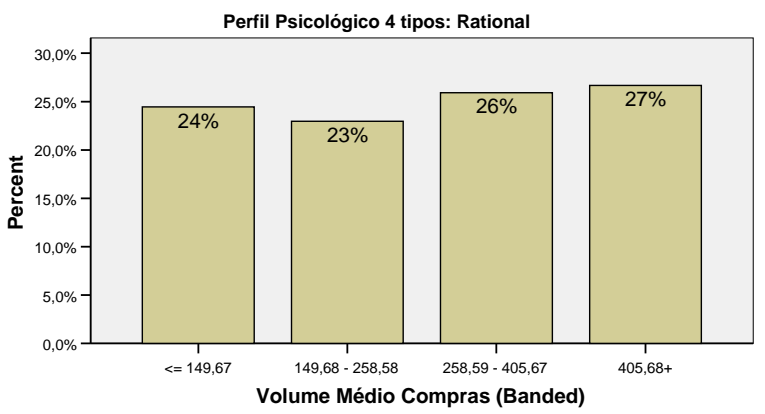

Gráfico 33 - Rationals: Volume Médio de Compras



Gráfico 34 - Idealists: Volume Médio de Compras

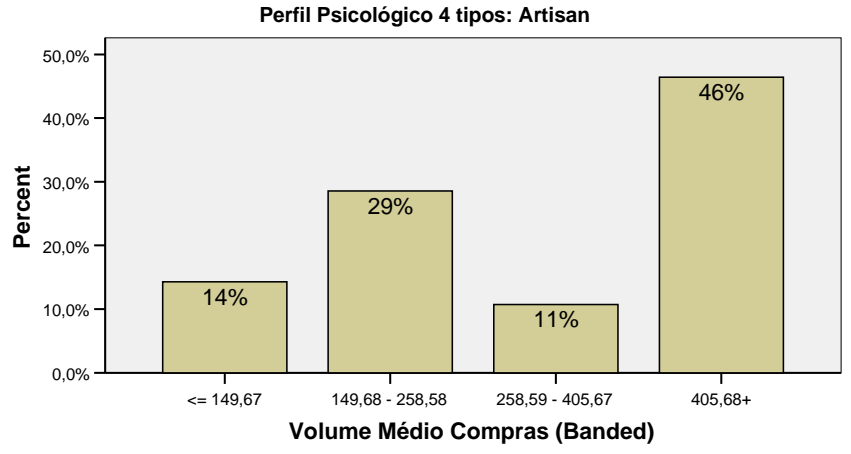

Gráfico 35 - Artisans: Volume Médio de Compras

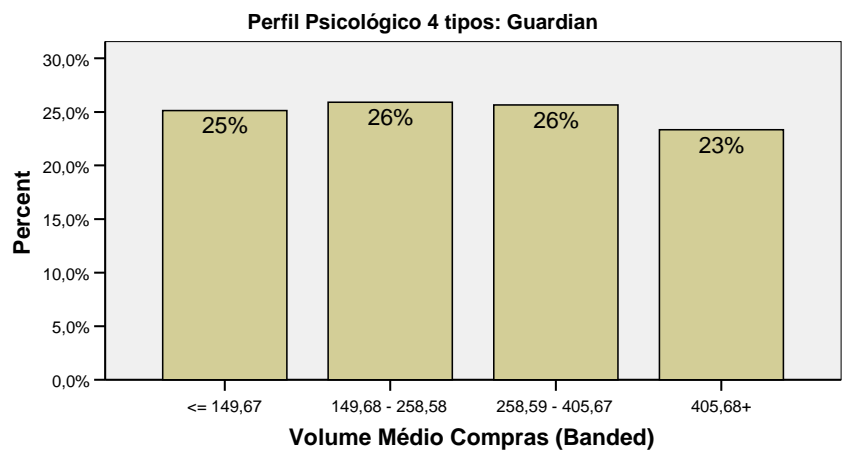

Gráfico 36 - Guardians: Volume Médio de Compras 
Análise Gráfica: Os 4 Temperamentos vs. Gastos com Cartão / Renda

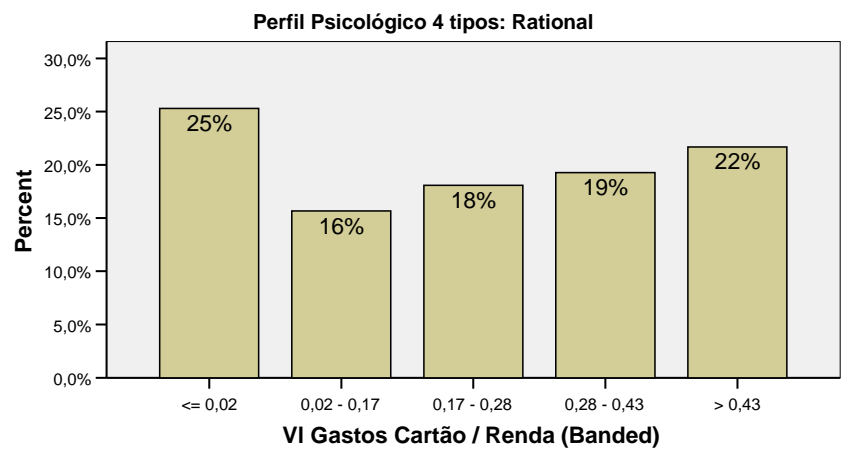

Gráfico 37 - Rational: Valor de Gastos com Cartão de Crédito / Renda

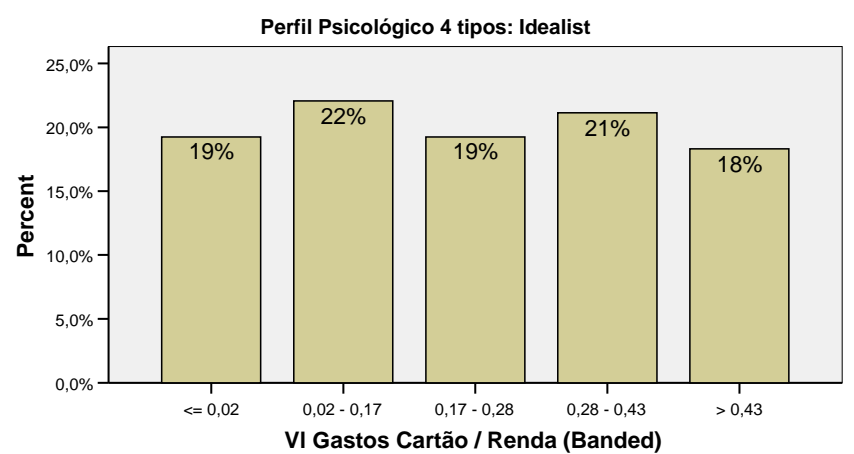

Gráfico 38 - Idealist: Valor de Gastos com Cartão de Crédito / Renda

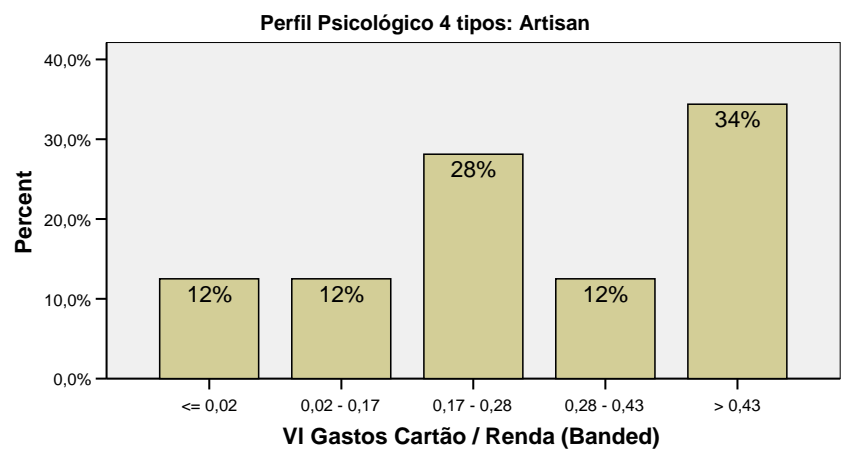

Gráfico 39 - Artisan: Valor de Gastos com Cartão de Crédito / Renda

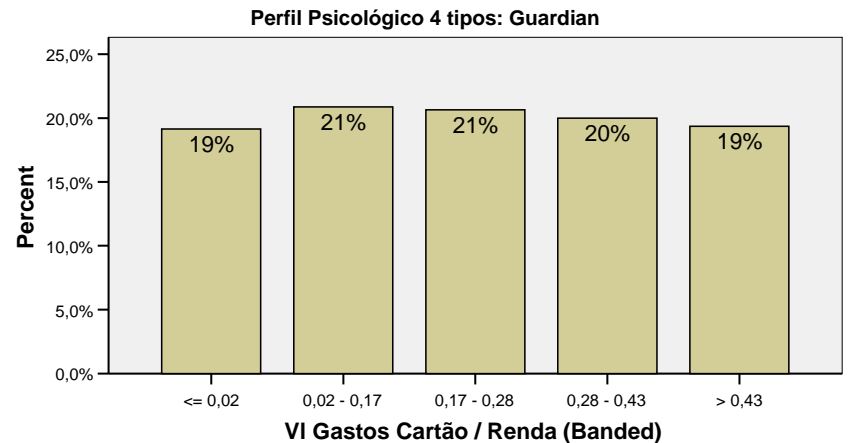

Gráfico 40 - Guardian: Valor de Gastos com Cartão de Crédito / Renda 
Os Artisans, por Linden (2000; p.124) classificados como Players, apresentam dificuldade no controle de seu orçamento financeiro, uma vez que "Being forced to stay within limits is stressful for players; that's why they're very inclined to borrow when funds are limited".

É exatamente o que ocorre quando se faz uso do crédito rotativo no cartão de crédito, ou seja, no momento em que se deve pagar a fatura do cartão, o portador pode optar por pagar apenas parte da mesma e financiar o restante, com incidência de juros sobre o valor financiado. O exercício dessa opção se dá quando o portador não dispõe de recursos suficientes para saldar seu compromisso de uma só vez, caso pagasse integralmente a fatura, provavelmente por não dispor dos recursos naquela situação, sendo forçado a utilizar uma alternativa de alto custo financeiro.

Os gráficos apresentados a seguir indicam que os Artisans fazem uso de um maior volume de rotativo e comprometem mais a sua renda com esse tipo de crédito do que os demais temperamentos, ainda que evidências estatísticas não tenham sido verificadas nos testes realizados. 
Análise Gráfica: Os 4 Temperamentos vs. Volume Médio de Rotativo

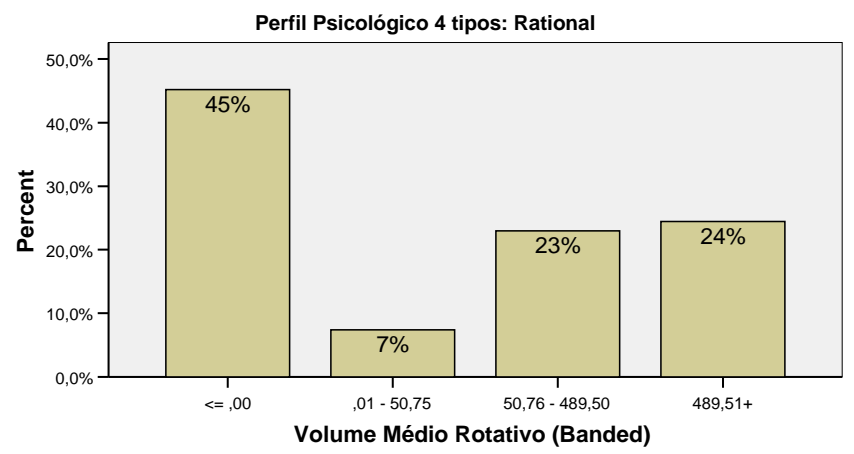

Gráfico 41 - Rational: Volume Médio de Rotativo

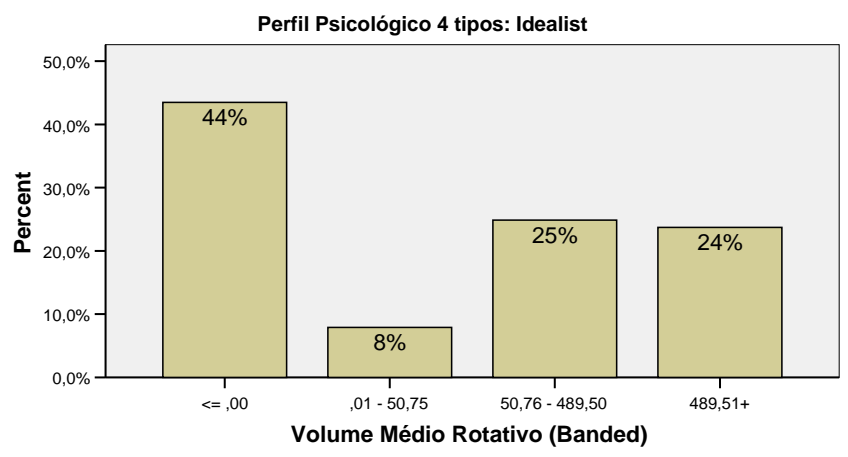

Gráfico 42 - Idealist: Volume Médio de Rotativo

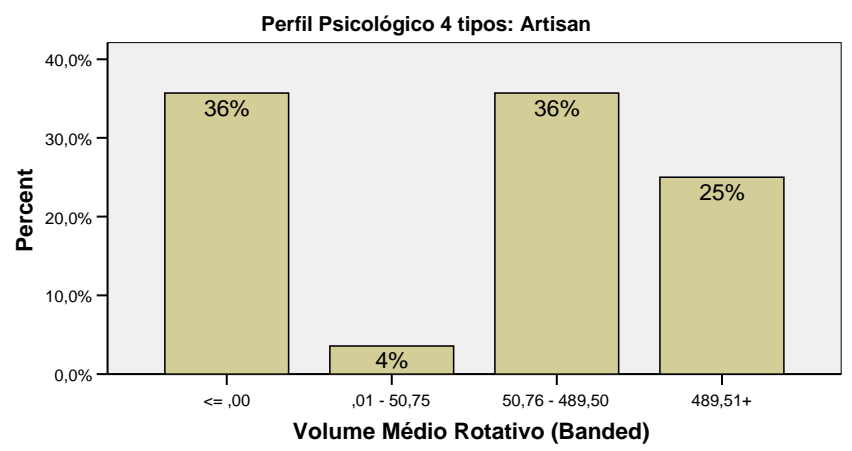

Gráfico 43 - Artisan: Volume Médio de Rotativo

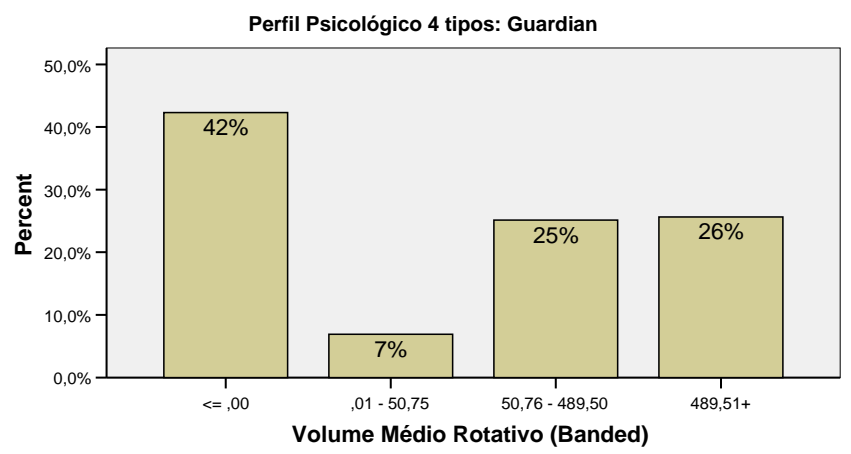

Gráfico 44 - Guardian: Volume Médio de Rotativo 
Análise Gráfica: Os 4 Temperamentos vs. Crédito Rotativo / Renda

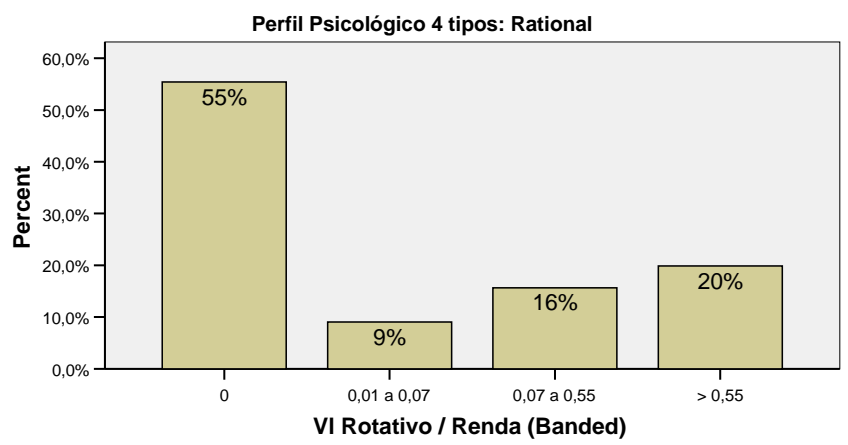

Gráfico 45 - Rational: Rotativo / Renda

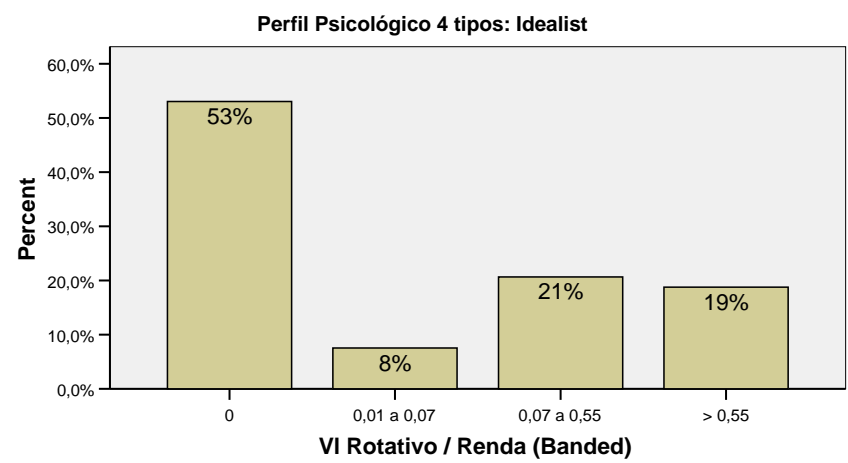

Gráfico 46 - Idealist: Rotativo / Renda

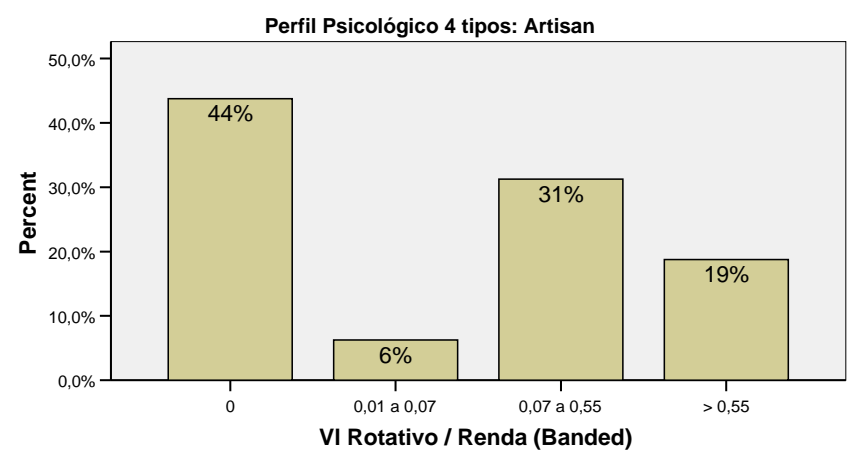

Gráfico 47 - Artisan: Idealist: Rotativo / Renda

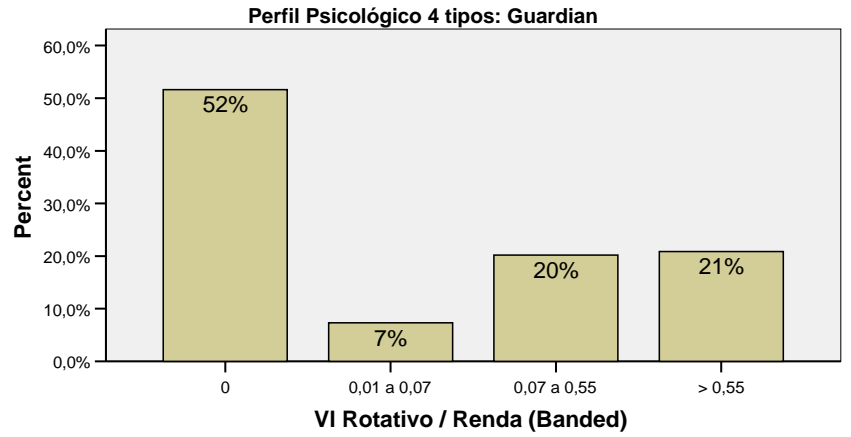

Gráfico 48 - Guardian: Rotativo / Renda 
Na primeira hipótese que se formulou para essa pesquisa buscava-se apurar a existência de correlação entre os tipos psicológicos e os hábitos de consumo de cartão de crédito, tendo sido essa hipótese confirmada por não ter sido possível rejeitar-se de maneira estatisticamente significante a independência do uso de cartão de crédito com a atitude Extroversão, conforme se pode verificar ao longo do trabalho.

No entanto, a questão proposta de que os Artisans possuiam um comportamento distinto no que se refere ao uso de cartão de crédito, sustentada pela análise gráfica descrita anteriormente, sugere que uma nova pesquisa possa vir a ser realizada para se buscar evidências estatísticas dessa hipótese, possivelmente não confirmada em razão do reduzido número de representantes desse temperamento na amostra no estudo realizado. 
Novos estudos visando apurar a possível existência de associação entre os tipos psicológicos e comportamentos de inadimplência também poderão ser realizados. A ampliação do conhecimento nessa importante área financeira que é a análise de crédito poderá reduzir as perdas com inadimplência e permitir uma redução do spread praticado que carrega em sua constituição uma parcela significativa para fazer frente às citadas perdas em créditos concedidos.

A redução do spread bancário resulta na redução dos juros praticados com importantes conseqüências sobre a demanda por crédito e a atividade econômica, impulsionando o seu crescimento.

Um possível refinamento do estudo proposto poderá levar também à construção de modelos que venham a permitir a apuração da probabilidade de inadimplir em função do tipo psicológico, seus temperamentos e dimensões, fornecendo assim um ferramental de maior qualidade e precisão no tratamento desse tema.

Outro estudo que poderá derivar deste é o que buscará associar as demandas por serviços financeiros em função dos tipos psicológicos, produzindo uma maior assertividade na difícil sintonia entre oferta e demanda, reduzindo custos incorridos quando se ofertam serviços não desejados ou desnecessários, aumentando a eficácia global do sistema e conferindo ao CRM - Customer Relationship Management, um papel de maior relevância resultante da incorporação da contribuição da Psicologia Social ao seu espectro de análise e operação. 
É importante frisar-se que a nova logística de distribuição bancária serve-se da sutil e importante característica da pré-identificação do cliente, quando do início de seu contato com a instituição financeira por intermédio de canais eletrônicos, atualmente responsáveis aproximadamente $85 \%$ das transações de varejo (Febraban, 2006).

Tendo-se em vista que há evidências que permitem rejeitar a hipótese nula de não associação entre tipos psicológicos e determinados comportamentos financeiros, pode-se sugerir estudos que venham a avaliar quais abordagens mercadológicas devem ser utilizadas para cada segmento visando uma melhor aceitação de uma oferta específica de serviço financeiro voltada para cada tipo da população e, se possível, para cada cliente, no limite do marketing one-to-one.

Os segmentos, que determinarão o comportamento padrão dos clientes, podem ser obtidos através de Análise de Cluster, conjunto de técnicas estatísticas multivariadas, cuja principal finalidade é agrupar objetos com base em suas características. A Análise de Cluster classifica objetos de modo que cada objeto seja muito similar aos outros do segmento (HAIR, Joseph, 1995).

Assim sendo, uma maior capacidade de satisfação da necessidade do cliente resulta em vantagem competitiva para a instituição que possui ferramental mais poderoso para esse fim.

No ambiente de serviços a função do Recurso Humano desempenha papel principal. A administração de recursos humanos teve sua grande impulsão com a 
célebre experiência de Hawthorne conduzida por Elton Mayo entre 1927 e 1932, dando origem à Escola de Relações Humanas.

As conclusões dos estudos de Elton Mayo trazem para a teoria administrativa a consideração do aspecto humano, ou seja, as condições psicológicas sobre as quais o homem desenvolve o seu trabalho e que passam a conflitar com a noção de homem econômico da administração científica.

O experimento de Mayo lançou luz sobre variáveis que até então não eram consideradas no mundo do trabalho:

- Liderança

- Motivação

- Comunicação

- Organização informal

Essas variáveis podem sugerir uma investigação mais profunda num ambiente tão típico e de crescente importância como é o call center.

A Psicologia e a Sociologia têm apresentado grande contribuição para o avanço dessa área do conhecimento e permitido uma importante produção multidisciplinar e interdisciplinar. O presente estudo procurou servir-se dessa característica combinando disciplinas e buscando sinergias que viessem a produzir explicações e estabelecer vínculos entre comportamentos financeiros, desempenhos profissionais e tipos psicológicos. 
Segundo a IDC, empresa de consultoria com foco nos segmentos de Tecnologia da Informação e Telecomunicações e subsidiária da IDG, líder mundial em mídia de tecnologia, o mercado de call center no mundo é o que apresenta o maior crescimento dentre os segmentos de Tecnologia da Informação.

De acordo com a consultoria, no mundo, os serviços de call center renderam em 2005 US\$ 51,4 bilhões, e a previsão é que alcance US\$ 92 bilhões em 2010.

Tendo em vista que o ambiente de serviços, centrado no recurso humano, está entre os que mais apresentam expansão na economia mundial e que a dinâmica de oferta de serviços passa por uma revisão na sua logística de distribuição que confere aos canais eletrônicos sua maior parcela de representatividade, é razoável propor-se um aprofundamento do estudo a respeito do atendente do call center, elemento que desempenha a função que deverá representar, potencialmente em breve, uma das maiores categorias em oferta de empregos na economia.

Segundo a ABT, Associação Brasileira de Teleserviços, o call center absorve a população mais afetada pelo desemprego. Atualmente emprega 675 mil pessoas, sendo $76 \%$ desse total mulheres, das quais, $45 \%$ jovens no primeiro emprego com faixa etária entre 18 e 24 anos.

A previsão da ABT para 2007 é de que 75 mil novos postos de trabalho sejam criados em call center, mantendo o ritmo de crescimento do setor no patamar de 
$10 \%$, bastante superior, portanto aos índices experimentados pela economia nacional.

O ambiente do call center é profundamente diferenciado de outros ambientes de trabalho, mas muito semelhante a outros ambientes da mesma natureza.

As avaliações da "posição de atendimento" descritas pela situação ergonômica, iluminação, dimensão e demais atributos físicos revestem-se de importância para a concepção do ambiente de trabalho mais adequado para o exercício da função de atendente. Um estudo que leve em consideração seu impacto sobre o desempenho e a motivação do atendente também se reveste de interesse.

A grande quantidade de recursos humanos num mesmo espaço físico, a organização informal, processos de comunicação e manifestações de liderança que dele derivam ensejam desafios para o seu gerenciamento, resultantes das conseqüências da homogeneização de ambientes e funções, só encontrando paralelo nas linhas de produção clássicas da revolução industrial, ressalvando-se, entretanto, que o escopo do trabalho, o perfil do recurso humano, a tecnologia e as ferramentas de gestão dos recursos humanos e sua avaliação e acompanhamento de performance são hoje bastante distintas.

Estudar-se, portanto, esse novo e complexo ambiente que integra de forma crescente um enorme contingente de recursos humanos que desempenha papel 
cada vez mais crucial no relacionamento com os clientes das organizações é, sem dúvida, matéria de grande atenção.

Outro tema que deriva da dinâmica da operação de um call center é a velocidade e a flexibilidade necessárias à sua adequação para o atendimento das demandas verificadas num mercado que passa por freqüentes mudanças.

Nesse contexto um estudo que busque um maior aprofundamento a respeito dos modelos de aprendizagem e técnicas de treinamento voltadas para o aprimoramento do atendimento e desenvolvimento comercial deverá encontrar um material profícuo e de grande interesse para pesquisa.

O atendente de call center caracteriza-se como agente protagonista da revisão da logística de distribuição bancária das instituições financeiras de varejo, tendo em vista a grande evolução da importância de seu trabalho com a crescente migração das transações e do relacionamento dos clientes para os canais de conveniência, representados pelos canais eletrônicos e sua peculiaridade de préidentificação do contato antes do início da transação/relacionamento.

Considerando-se a relevância econômica e social que despertam de forma crescente a figura do atendente e a instituição do call center propriamente dita, um estudo mais específico a respeito do perfil dos atendentes deverá apresentar significativa contribuição ao tema e poderá explorar com maior aprofundamento a interpretação de evidências estatísticas aqui encontradas. 
As evidências encontradas indicam associações entre as variáveis demográficas, sexo e idade, e o perfil psicológico. Os homens concentraram-se mais na função Pensamento enquanto as mulheres na função Sentimento. Mesmo considerando que a amostra é formada por indivíduos mais jovens, observou-se que entre os mais "maduros" aumenta a incidência da função Sensação.

Indivíduos com prevalência da função Sensação são mais detalhistas, extraem informações através dos 5 sentidos e observam aquilo que é real. Podendo indicar, assim, que os indivíduos evoluem no sentido "observador" à medida que ficam mais maduros, explorando mais a forma de trabalhar as informações adquiridas. É possível também que os indivíduos evoluam nessa direção em razão da natureza da função que desempenham que deles exige uma especial dedicação a esse atributo.

Também pode se observar que houve uma maior concentração dos homens no temperamento Rational, enquanto as mulheres se concentraram nos temperamentos Guardian e Idealist. Adicionalmente constatou-se que os mais "maduros", considerando que a amostra é de jovens, concentram-se mais no temperamento Guardian, reduzindo os percentuais de Idealists e Rationals.

Uma amostra de indivíduos empreendedores, detentores de negócios com mais de dois anos de operação, foi estudada por Lopes (2004) que identificou os objetivos dos mesmos quando da abertura de seus negócios e seus objetivos atuais, suas estratégias de ação e sua orientação de tempo. Lopes (op.cit) pesquisou a 
associação dessas variáveis com os tipos psicológicos dos indivíduos empreendedores e encontrou significativas associações entre os mesmos.

Considerando-se que o call center representa de forma majoritária a porta de ingresso na instituição financeira, o estudo de Lopes (op.cit) reveste-se de interesse na medida em que contribui para a avaliação do atendente, com o propósito de se identificar e alocar corretamente os empreendedores que poderão, no desenvolvimento de sua carreira, se transformar nos intrapreneurs, impulsionando a organização em direções inovadoras.

Há, portanto, uma série de estudos que oferecem grande oportunidade de contribuição para o tema que derivam dessa pesquisa.

A realização dos mesmos deverá proporcionar uma ampliação no conhecimento atual e oferecer a possibilidade de se reduzir o gap existente entre o entendimento da evolução do indivíduo, a administração e a tecnologia, conforme se apresenta na Figura 40. 
Figura 40 - Contribuição da Psicologia para a interpretação do conhecimento do consumidor

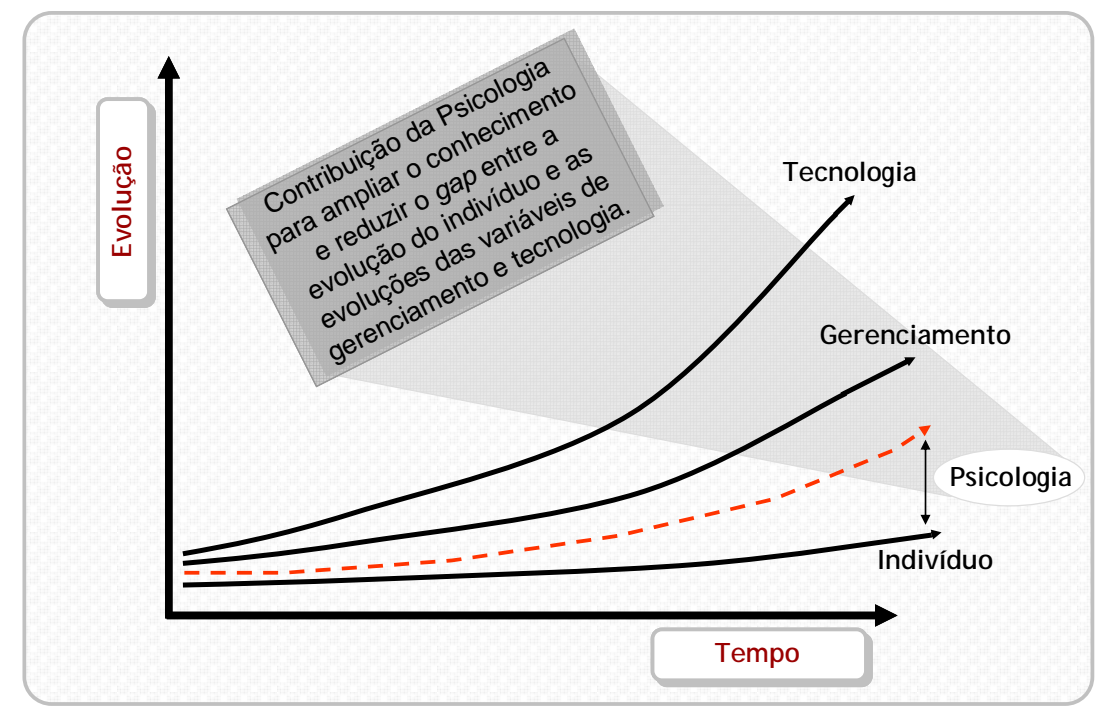

Fonte: Adaptado de Palazzo 


\section{REFERÊNCIAS BIBLIOGRÁFICAS}

ABT Associação Brasileira de Teleserviços. Pesquisa da PUC-SP radiografa o call center brasileiro. 2006. Disponível em: <http://www.abt.org.br>. Acesso em: 15 de março de 2007.

AIBAR, Eduardo P. La vida social de las máquinas: orígenes, desarrollo y perspectivas actuales de la sociología de la tecnología. Revista Española de Investigaciones Sociales, n. 76, oct./dic. 1996.

ANDERSON, Chris. A Cauda Longa: do mercado de massa para o mercado de nicho. Tradução Afonso Celso da Cunha Serra. Rio de Janeiro: Elsevier, 2006, p. 1724.

ANGELO, Cláudio Felisoni de, GIANGRANDE, Vera (coordenadores). Marketing de Relacionamento. São Paulo: Editora Atlas, 1999.

BADER, Marcos. Banco Virtual: Revista GV-executivo, Fundação Getúlio Vargas. São Paulo: FGV-EAESP, volume 5, número 3, julho/agosto, 2006. p. 24-29.

Banco Central do Brasil. O Banco Central e as novas técnicas de saneamento do Sistema Financeiro Nacional após a estabilização: Panorama atual do Sistema Financeiro Nacional e necessidade de sua reordenação no ambiente de estabilização. Disponível em: <http://www.bcb.gov.br/htms/livrosfn.asp?idpai=artregesp>. Acesso em: 14 de março de 2007.

BECK, Don Edward; COWAN, Christopher C. Spiral Dynamics - Managing Values, Leadership and Change: Blackwell Publishers, 1996.

BOCK, Ana M. Bahia; FURTADO, Odair; TEIXEIRA, Maria de Lourdes T. Uma Introdução ao Estudo da Psicologia. São Paulo: Editora Saraiva, 1999.

BOLWIJN, P.T.; KUMPE, T. "Manufacturing in the 1990s - Productivity, Flexibility and Innovation": Long Range Planning, vol. 23, n 4, 1990. p. 44-57.

BRETZKE, Miriam. Marketing de relacionamento para competir em tempo real. São Paulo: Atlas, 2000.

BROWN, Stanley A. CRM - Customer Relationship Manangement: uma ferramenta estratégica para o mundo e-business. São Paulo: Makron Book, 2001. 
BRUNSTEIN, Israel. Economia de Empresas: gestão econômica de negócios. São Paulo: Atlas, 2005.

Canal Executivo. Bancos vão gastar R\$ 11,5 bilhões com TI em 2004. 2004. Disponível em: <http://www2.uol.com.br/canalexecutivo/notasemp/emp090320041.htm>. Acesso em: 17 de março de 2007.

Canal Executivo. Bancos gastaram R\$ 18 bilhões com TI em 2005. 2006. Disponível em: <http://www2.uol.com.br/canalexecutivo/notas06/180420063.htm>. Acesso em: 17 de março de 2007.

CARLEY, Kathleen M. Smart agents and organization of the future. 2002. Disponível em: < www.hss.cmu.edu/departments/sds/faculty/carley/publications/ORG>. Acesso em: 21 de janeiro de 2007.

CARMOY, Hervé de. Estratégia Bancária: a recusa da descoordenação. Lisboa: Dom Quixote, 1992.

CHANDLER, Daniel. Technological or Media Determinism. 1995. Disponível em: $<$ http://www.aber.ac.uk/media/Documents/tecdet/tecdet.html>. Acesso em: 24 de janeiro de 2007.

CHIAVENATO, I. Introdução à Teoria Geral da Administração. $4^{\circ}$ edição. São Paulo: Makron Books, 1993.

CIAB Febraban 2006. A Sociedade Virtual. Transações bancárias e automação. 2006.

<http://www.febraban.org.br/ciab06/Portuques/Dados do setor/transacoes.asp>. Acesso em: 15 de março de 2007.

CIASHOP. Varejo online atinge mais de US\$ 100 bilhões em 2006 nos EUA.2007 Disponível em: <http://site.ciashop.com.br/noticia.asp?id=127>. Acesso em: 03 de Fevereiro de 2007.

CONGER, John P. Jung e Reich: o corpo como sombra. São Paulo: Summus Editorial, 1993.

COSTA NETO, Pedro Luiz de Oliveira. Estatística. São Paulo: Edgar Blucher, 1977. 
COSTA, Julio Reis. A Virtualização no Sistema Financeiro Brasileiro: Estudo de Caso no Banco do Brasil - Dissertação apresentada ao Programa de PósGraduação em Engenharia de Produção - Universidade Federal de Santa Catarina FLORIANÓPOLIS, 2004.

CRUZ, Tadeu. Sistemas, Organização \& Métodos: estudo integrado das novas tecnologias de informação. São Paulo: Editora Atlas, 1997.

DAVIS, Stan; MEYER, Christopher. Blur: A velocidade da mudança na economia integrada. Rio de Janeiro: Campus, 1999.

DOWING, Douglas; CLARK, Jeffrey. Estatística Aplicada. Tradução Alfredo Alves de Farias - 2. ed. - São Paulo: Saraiva, 2002.

ENGEL, James F.; BLACKWELL, Roger D.; MINIARD, Paul W. Comportamento do Consumidor. Rio de Janeiro: Livros Técnicos e Científicos Editora S.A., 2000.

FARRELL, Paul B. The Millionaire Code: 16 paths to wealth building. New Jersey: John Wiley \& Sons, Inc., 2003.

FLINT, David. "Sharpening the Customer Focus". The IT Journal, segundo trimestre 1997. p. 4-23.

Folha OnLine. Internauta brasileiro bate recorde em tempo de navegação. 2007. Disponível em: <http://www1.folha.uol.com.br/folha/informatica/ult124u21458.shtml>. Acesso em: 04 de março de 2007.

FRIEDMAN, Thomas. O mundo é plano: Uma breve história do século XXI. Rio de Janeiro: Objetiva, 2005.

GARTNER Group. Management Update: B2B CRM Trends in the Manufacturing Industry. InSide Gartner Group. Sep, 2000.

GIANNETTI, Eduardo. Felicidade. São Paulo: Companhia das Letras, 2002.

O valor do amanhã: ensaio sobre a natureza dos juros. São Paulo: Companhia das Letras, 2005.

GIBSON, Rowan. Repensando o Futuro. São Paulo: Makron Books, 1998. 
GIGLIO, Ernesto. O Comportamento do Consumidor e a Gerência de Marketing. São Paulo: Editora Pioneira, 1996.

GITMAN, Lawrence Jeffrey. Princípios de Administração Financeira: $10^{a}$ edição. Tradução Antônio Zoratto Sanvicente. São Paulo: Addison Wesley, 2004, p. 18-19.

GORDON, Ian. Marketing de relacionamento: estratégias, técnicas e tecnologias para conquistar clientes e mantê-los para sempre. Tradução Mauro Pinheiro. São Paulo: Futura, 1999. 31 p.

GREENBERG, Paul. CRM, customer relationship management na velocidade da luz: conquista e lealdade de clientes em tempo real na internet. Rio de Janeiro: Campus, 2001.

GROSSMANN, Volker. Is it rational to internalize the personal norm that one shold reciprocate? Journal of economic Psychology. North-Holland. 23, 2002 p. 2748.

GÜTH, Werner and Menachem YAARI (1992). "Explaining reciprocal behavior in simple strategic games: An evolutionary approach", in: Ulrich Witt (ed.), Explaining process and change: Approaches to evolutionary economics. Michigan University Press.

HAIR JR, Joseph F., ANDERSON, Rolph E., TATHAM, Ronald L. and BLACK, William C. Multivariate Data Analysis. 4Th Edition. Prentice Hall. New Jersey. 1995.

HALL, Calvin S.; NORDBY, Vernon J. Introdução à Psicologia Junguiana. São Paulo: Editora Cultrix, 1993.

HAMEL, Gary; PRAHALAD, C.K. Competing for the Future. Harvard Businnes School Press, 1994.

HUGLES, Arthur M. Database Marketing Estratégico. São Paulo: Makron Books, 1998.

IBM Business Consulting Services - IBM Institute for Business Value. O Paradoxo da Indústria Bancária em 2015, 2006. (apud) O conceito "well curve" foi descrito no seguinte artigo: Pink, Daniel $\mathrm{H}$. "The Shape of Things to Come." Wired. Maio de 2003. 
IBOPE. Novo recorde marca início da popularização da Internet no Brasil. 2007. Disponível em: $<$ http://www.ibope.com.br/calandraWeb/servlet/CalandraRedirect?temp=5\&proj=Port allBOPE\&pub=T\&db=caldb\&comp=Noticias\&docid=8684A155B5E2872F832572C90 0698099 >. Acesso em: 03 de maio de 2007.

IDC Brasil. Mercado brasileiro de Call Center caminha para estágio de maturidade. 2006.

$<$ http://www.idcbrasil.com.br/news.asp?ctr=bra\&year=2006\&id release=842>.

Acesso em: 15 de março de 2007.

IMAI, Masaaki. Kaizen: A Estratégia para o Sucesso Competitivo. São Paulo: IMAM, 1990.

JACKSON, Robert R.; WANG, Paul. Database Marketing Estratégico. São Paulo: IDBM - Instituto Brasileiro de Database Marketing, 1997. Edição Pré-Lançamento em Português.

KARSAKLIAN, Eliane. Comportamento do Consumidor. São Paulo: Editora Atlas, 2000.

KEIRSEY, David. Please Understand Me II: Temperament, Character, Intelligence. Del Mar, CA: Prometheus Nemesis Book Company, 1998.

KOTLER, Philip. Marketing para o século XXI: como criar, conquistar e dominar mercados. São Paulo: Futura, 1999.

KOTLER, Philip; ARMSTRONG, Gary. Princípios de Marketing. Tradução Arlete Simille Marques, Sabrina Cairo, $9^{\circ}$ edição. São Paulo. Prentice Hall, 2003. p. 204226.

LAPPONI, Juan Carlos. Estatística usando Excel. São Paulo: Lapponi Treinamento e Editora, 2000.

LEVITT, Theodore, Miopia em Marketing. 1a Publicação HBR, julho-agosto de 1960 - Reprint, Havard Business Review, p. 88, outubro, 2006.

LINDER, Ray. What will I do with my money? How your personality affects your financial behavior. Chicago: Northfield Publishing, 2000. 
LOPES, Rose Mary Almeida. Personalidade e Tipos Psicológicos de Empreendedores: Um Estudo Exploratório, Tese de Doutorado apresentada ao Programa de Pós-Graduação em Psicologia Social. Universidade de São Paulo São Paulo, 2004.

MALHOTRA, Naresh; Pesquisa de marketing: uma orientação aplicada. Tradução de Nivaldo Montingelli Jr. e Alfredo Alves de Farias. $3^{\circ}$ ed. Porto Alegre: Bookman, 2001.

MIRANDA, Mauro Costa. Crises cambiais e ataques especulativos no Brasil. Banco Central, trabalhos para discussão no. 32, nov. 2001. Disponível em:

<http://www.bcb.gov.br/pec/wps/port/wps32.pdf.> Acesso em: 15 de janeiro de 2007.

MODAHL, Mary. Agora ou Nunca: reinventando a empresa para vencer na Internet. Rio de Janeiro: Editora Campus, 2000.

MYERS, Isabel Briggs; McCAULLEY, Mary $\mathrm{H}$. Manual, a guide to the development and use of the Myers-Briggs type indicator. Palo Alto, CA: Consulting Psychologists Press, Inc., 1992.

Negócios Virtuais. Crescem os números do comércio eletrônico brasileiro em 2006. 2007. Disponível em: <http://negociosvirtuais.blogspot.com/2007/04/crescem-osnmeros-do-comrcio-eletrnico.html>. Acesso em: 04 de março de 2007.

NEGROPONTE, Nicholas. A Vida Digital. São Paulo: Companhia das Letras, 1995. p. 143-144.

NÓBREGA, Clemente. Supermentes: do big bang à era digital. São Paulo: Negócio, 2001.

Novo Milênio. Empresas já vêm CRM como necessidade crítica. 2001. Disponível em: <www.novomilenio.inf.br/ano01/0106d004.htm>. Acesso em: 04 de março de 2007.

PALAZZO, Antônio Sávio Passos. Nos Limites da Administração Moderna. Rio de Janeiro: Produção independente, 1993.

PEPPERS, Don; ROGERS, Martha. Enterprise One To One: Tools for Competing in the Interactive Age. New York: Currency DoubleDay, 1997. 
PESTANA, Maria Helena; GAGEIRO, João Nunes. Análise de Dados para Ciências Sociais: A Complementaridade do SPSS. 4ª edição. Lisboa, 2005.

PORTER, Michael E. Competitive strategy. New York Free Press, 1980.

Estratégia Competitiva: Técnicas para a Análise de Indústrias e da Concorrência. Rio de Janeiro: Editora Campus, 1986, p.24.

. Vantagem Competitiva: Criando e Sustentando um Desempenho Superior. Rio de Janeiro: Editora Campus, 1989, p.2 e p.9.

REIS, Alberto O. Advincula; MAGALHÃES, Lúcia Maria Azevedo; GONÇALVES, Waldir Lourenço. Teorias da Personalidade em Freud, Reich e Jung. São Paulo: Editora Pedagógica e Universitária Ltda., 1994.

Revista Veja. Parece mágica: Inovar ou morrer é a lei nesse vale; Almanaque da mobilidade. São Paulo: Editora Abril, 17 de janeiro de 2007. p. 57-67.

Revista Vejinha (Parte Integrante da Revista Veja ano 39 - n³3). Shopings: Tudo por um consumidor. São Paulo: Editora Abril, 23 de agosto de 2006. p. 24-28.

SAVÓIA, José Roberto Ferreira. A Globalização do Mercado Financeiro Brasileiro: Um Estudo de Implicações sobre a Competitividade. Tese de Doutorado. São Paulo: Faculdade de Economia, Administração e Contabilidade, Universidade de São Paulo, 1996.

. Finanças Empresariais Capital de Giro: material didático utilizado no Curso de MBA Gestão Empresarial. São Paulo. FIA - Fundação Instituto de Administração, 2004, p. 20-21.

SILVEIRA, Nise da. Jung: vida e obra. $7^{\text {a }}$ edição. Rio de Janeiro: Paz e Terra, 1981.

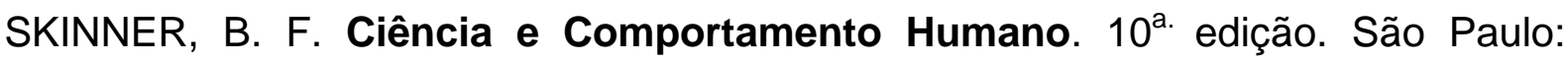
Martins Fontes, 2000.

STONE, Merlin; WOODCOCK, Neil. Marketing de Relacionamento. São Paulo: Littera Mundi, 1998. in online social networks via viral marketing. Commun. ACM 46(12): 300-307, 2003. 
TAPSCOTT, Don. Growing Up Digital: The Rise of the Net Generation. New York: McGraw-Hill, 1998.

Thaler. Os bancos no futuro e o papel da tecnologia. CIAB. 2003. Disponível em: <http://www.thaler.com.br/ciab2.asp > . Acesso em 14 de fevereiro de 2007.

UNDERHILL, Paco. Vamos às Compras: a ciência do consumo. Rio de Janeiro: Elsevier, Editora Campus, 1999. p. 43-44.

WILBER, Ken. A Theory of Everything. An Integral Vision for Business, Politics, Science and Spirituality. Dublin: Shambhala, 2001.

WITT, Ulrich. Economic, sociobiology, and behavioral psychology on preferences.Journal of Economic Psychology. North-Holland. 12 1991, p 557 - 573.

WOMACK, J.P.; JONES, D.T.; ROOS, D. A máquina que mudou o mundo. Rio de Janeiro: Campus,1992.

YAARI, M; HILLEL,M. Bar- "On Dividing Justly" Social Choice and Welfare, 1984. p. 1-24.

ZACHARIAS, José Jorge de Morais. Tipos: a diversidade humana. São Paulo: Vetor, 2006. 
11 ANEXOS

11.1 Base de Dados

11.1.1 Informações analíticas (Consultar volume 2) 
11.2 Testes Estatísticos (Consultar volume 2) 
